\title{
A Comparative Study of Teacher Preparation and Qualifications in Six Nations
}

Richard Ingersoll

University of Pennsylvania, rmi@upenn.edu

Follow this and additional works at: https://repository.upenn.edu/cpre_researchreports

Part of the Educational Sociology Commons, Education Economics Commons, Education Policy Commons, Elementary Education and Teaching Commons, and the Secondary Education and Teaching Commons

\section{Recommended Citation}

Ingersoll, Richard. (2007). A Comparative Study of Teacher Preparation and Qualifications in Six Nations. CPRE Research Reports.

Retrieved from https://repository.upenn.edu/cpre_researchreports/47

View on the CPRE website.

This paper is posted at ScholarlyCommons. https://repository.upenn.edu/cpre_researchreports/47

For more information, please contact repository@pobox.upenn.edu. 


\title{
A Comparative Study of Teacher Preparation and Qualifications in Six Nations
}

\begin{abstract}
Across the educational systems of the world, few issues have received more attention in recent years than the problem of ensuring that elementary and secondary-school classrooms are all staffed with adequately qualified teachers (Mullis, et al., 2000; OECD, 1994, 2005; Wang, et al., 2003). Even in nations where students routinely score high on international exams, the issue of teacher quality is the subject of much concern. This is not surprising. Elementary and secondary schooling is mandatory in almost all nations and children are legally placed in the care of teachers for a significant portion of their lives. It is widely believed that the quality of teachers and teaching are among the most important factors shaping the learning and growth of students. Moreover, this impact goes beyond student academic achievement. Across the world, observers routinely tie the performance of teachers to numerous, larger societal goals and problems-economic competitiveness and productivity, juvenile delinquency, moral and civic culture, and so on. In addition, the largest single component of the cost of education in any country typically is teacher compensation. Along with a general consensus among many nations that the quality of teachers and teaching is a vital resource, there is accordingly much concern surrounding how equitably this resource is distributed within educational systems. Indeed, some nations suffer from an apparent paradox -that despite an overall overproduction and oversupply of new teachers, there nevertheless appear to be substantial numbers of students without access to qualified teachers.
\end{abstract}

Such concern has resulted in a steady stream of commissions, reports, and studies all targeting teacher quality as one of the central problems facing school systems. In many nations this concern has resulted in new legislation and policy. Foremost among these have been widespread efforts to increase the entry standards and preparation requirements for teachers. Hong Kong, for instance, initiated in 1997 an "all graduate, all trained" policy requiring new primary- and secondary-school teachers to have bachelor's degrees and to be professionally trained. In Japan there has been an active reform movement to increase teacher preparation requirements and increase evaluation and accountability of teachers. In the United States this concern surfaced within a massive new piece of legislation in 2002, the federal law known as the No Child Left Behind Act, which in addition to new standards for student achievement, set a new and unprecedented goal - to ensure that elementary and secondary students in the United States are all taught by highly qualified teachers. In addition to, or perhaps because of, recognition of its importance, the issue of teacher quality also is a source of debate and disagreement in many nations.

\section{Disciplines}

Educational Sociology | Education Economics | Education Policy | Elementary Education and Teaching | Secondary Education and Teaching

\section{Comments}

View on the CPRE website. 
A Comparative Study of Teacher Preparation and Qualifications

in Six Nations

Edited by Richard M. Ingersoll

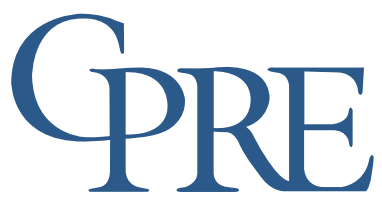




\section{ABOUT CPRE}

The Consortium for Policy Research in Education (CPRE) unites seven of the nation's top research institutions in an exciting venture to improve student learning through research on policy, finance, school reform, and school governance. The members of CPRE are the University of Pennsylvania, Teachers College Columbia University, Harvard University, Stanford University, the University of Michigan, the University of Wisconsin-Madison, and Northwestern University.

CPRE is currently examining how alternative approaches to reformsuch as new accountability policies, teacher compensation, whole-school reform approaches, and efforts to contract out instructional servicesaddress issues of coherence, incentives, and capacity.

To learn more about CPRE, visit our web site at www.cpre.org or call (215) 573-0700, and then press 0 for assistance.

\section{CPRE Research Report Series}

Research Reports are issued by CPRE to facilitate the exchange of ideas among policymakers, practitioners, and researchers who share an interest in education policy. The views expressed in the reports are those of individual authors, and not necessarily shared by CPRE or its institutional partners. 


\title{
A Comparative Study of Teacher Preparation and Qualifications in Six Nations
}

\author{
By \\ Richard M. Ingersoll, United States \\ With \\ Ding Gang and Sun Meilu, People's Republic of China (PRC) \\ Kwok Chan Lai, Hong Kong \\ Hidenori Fujita, Japan \\ Ee-gyeong Kim, Republic of Korea \\ Steven K. S. Tan and Angela F. L. Wong, Singapore \\ Pruet Siribanpitak and Siriporn Boonyananta, Thailand
}

\section{CPRE}

Consortium for Policy Research in Education

University of Pennsylvania / Teachers College - Columbia University

Harvard University / Stanford University

University of Michigan / University of Wisconsin-Madison

Northwestern University 


\section{Table of Contents}

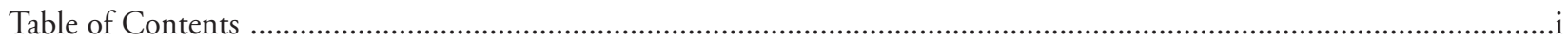

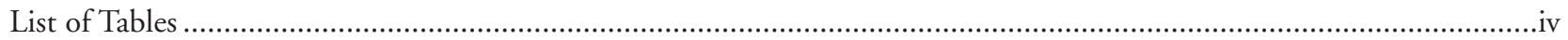

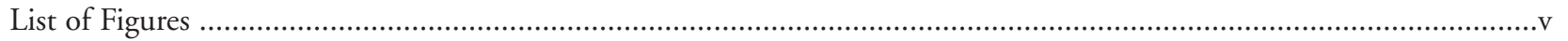

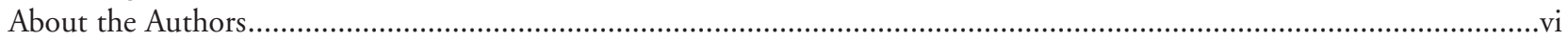

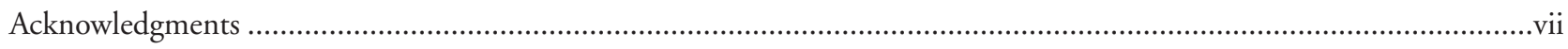

Chapter 1. A Comparative Study of Teacher Preparation and Qualifications in Six Nations ...................................1

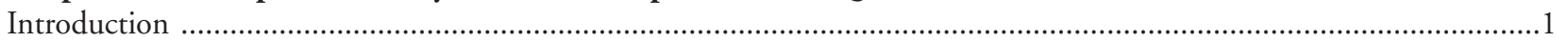

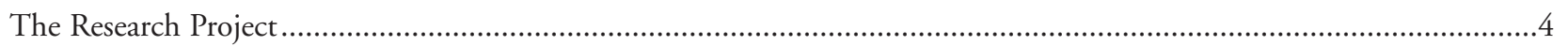

1.) What are the Preparation Requirements and Standards to Become a Teacher? ……..................................................

2.) What are the Levels of Qualifications of the Current Teaching Force? ......................................................................6

3.) What Proportions of Teachers are Not Qualified in the Subjects They Teach? ………..............................................6

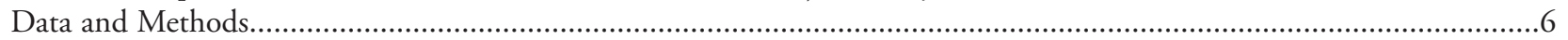

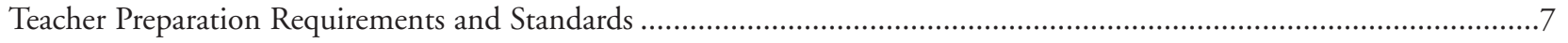

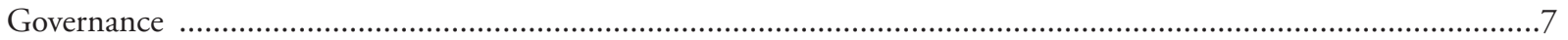

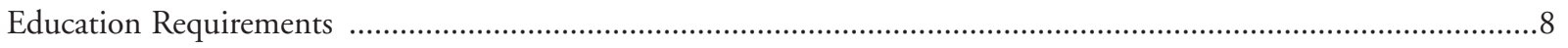

Professional Training Requirements .......................................................................................................

Selectivity of Programs, Caliber of Candidates and Attractiveness of Careers ...........................................................9

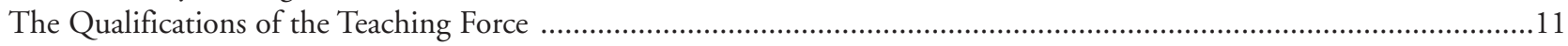

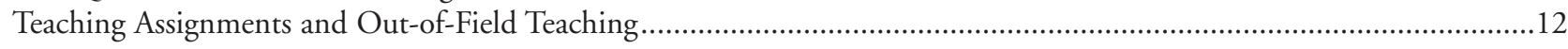

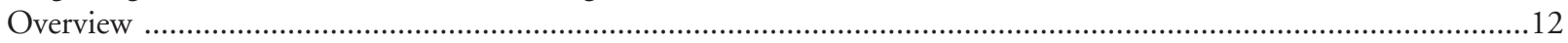

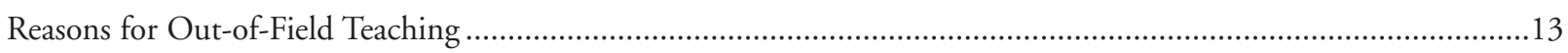

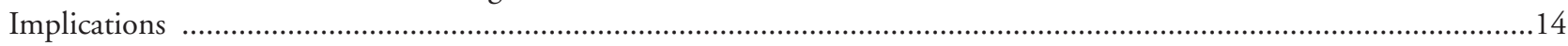

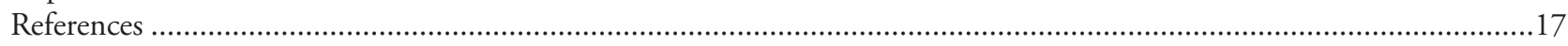

Chapter 2. The Qualifications of the Teaching Force in China ......................................................................................19

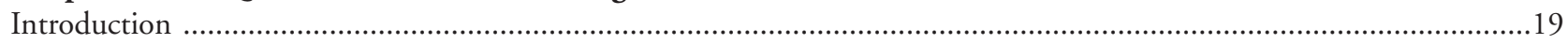

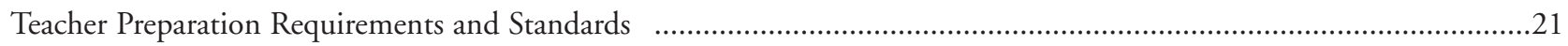

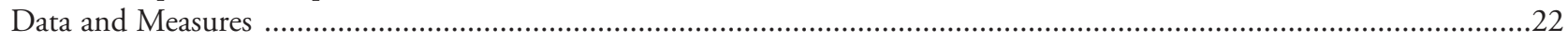

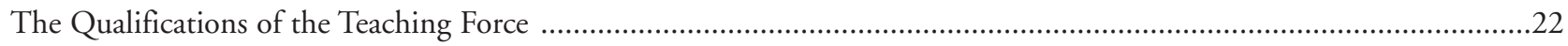

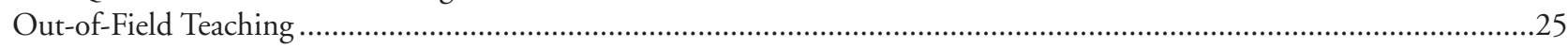

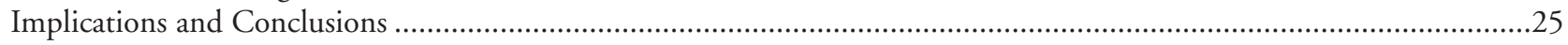

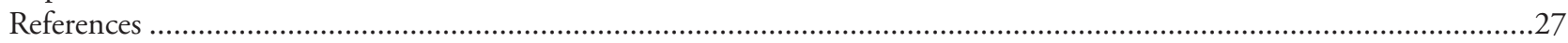

Chapter 3. The Qualifications of the Teaching Force in the Hong Kong Special

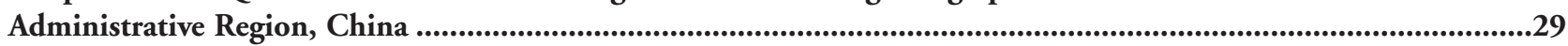

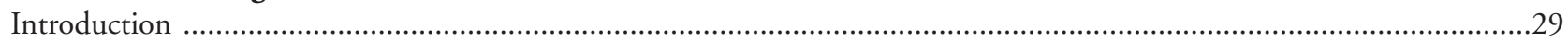

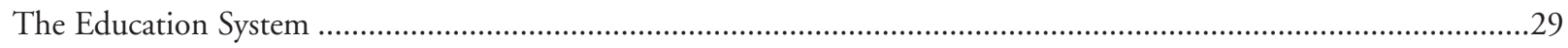

The Teacher Education System............................................................................................................

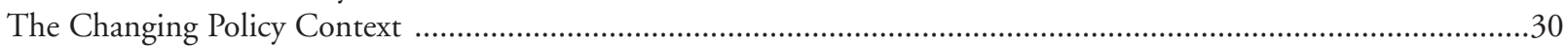

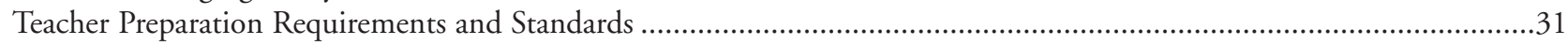

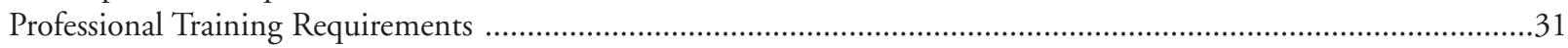

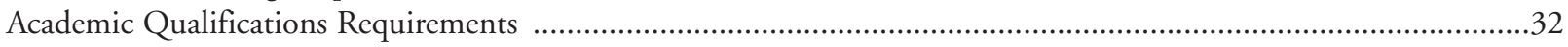

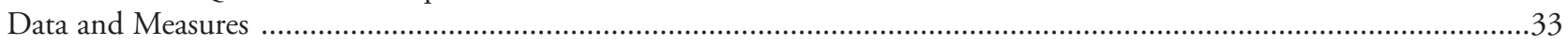

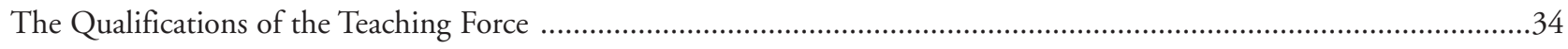

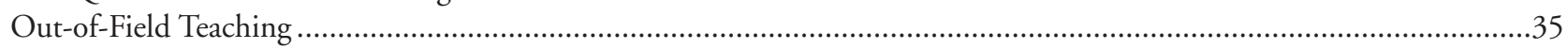

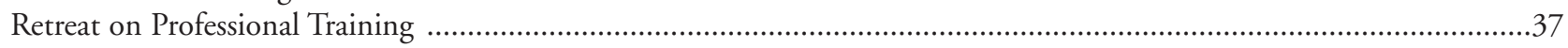

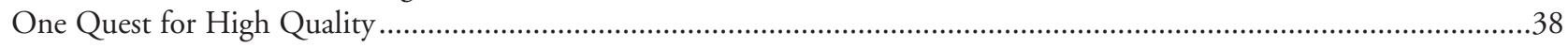

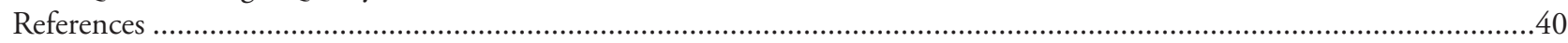




\section{Chapter 4.}

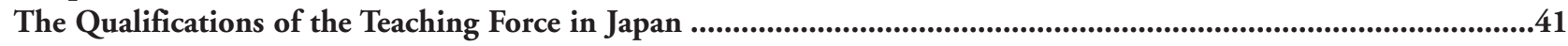

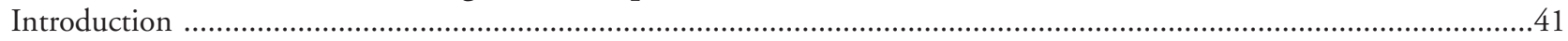

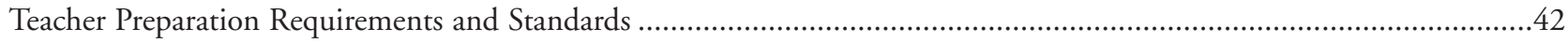

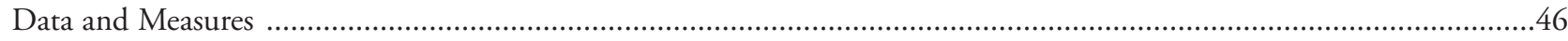

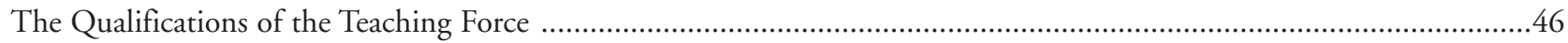

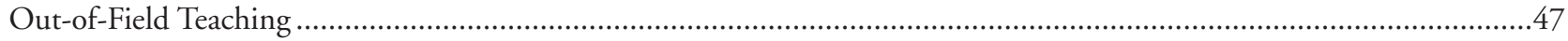

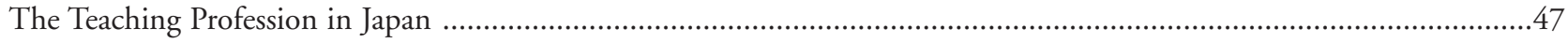

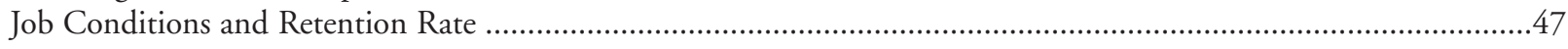

Teachers' Perceptions of Their Profession in Japan in Comparison with China

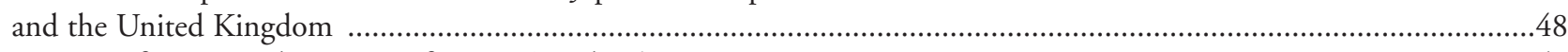

Impacts of Recent Education Reform on Teachers' Perceptions ...........................................................................49

Teachers' Perceptions of Their Work Lives in Japan in Comparison With China and the United Kingdom ....................50

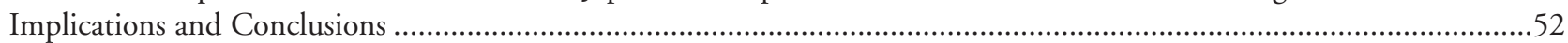

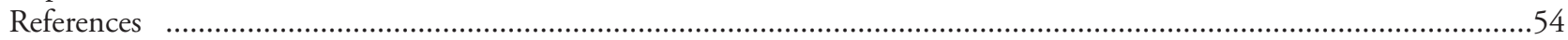

Chapter 5. The Quality and Qualifications of the Teaching Force in the Republic of Korea ....................................55

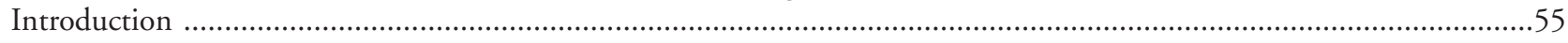

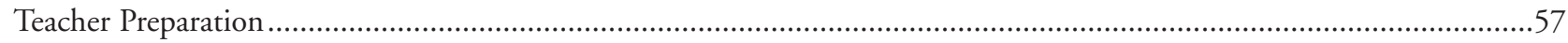

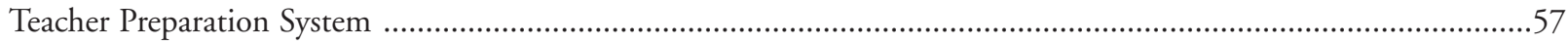

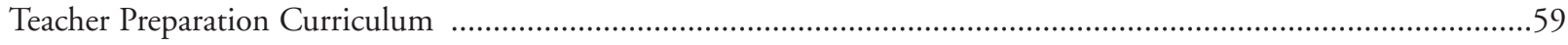

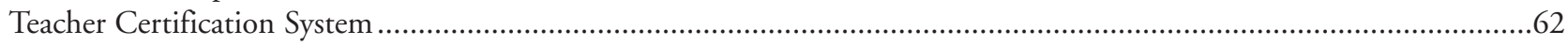

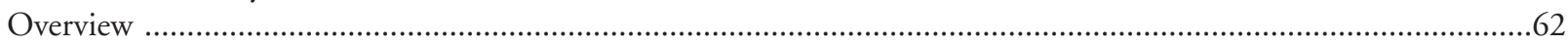

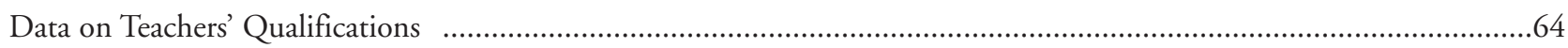

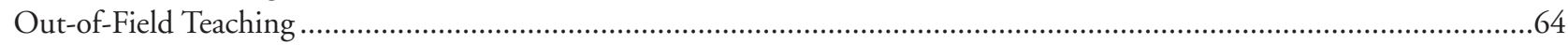

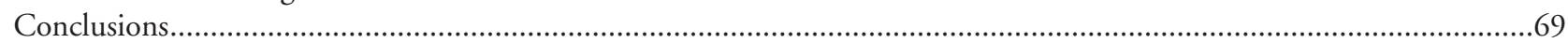

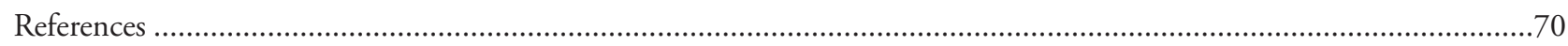

Chapter 6. The Qualifications of the Teaching Force: Data from Singapore................................................................71

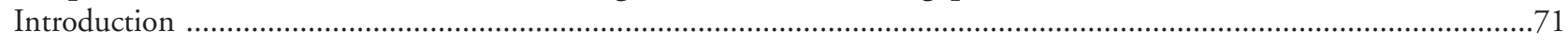

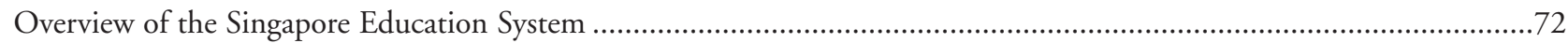

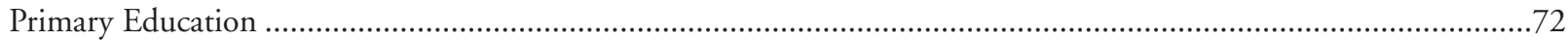

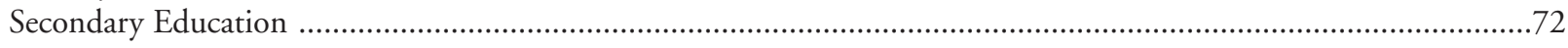

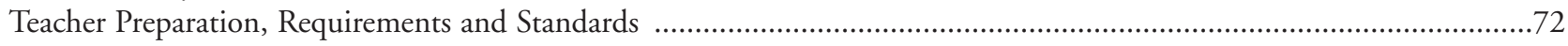

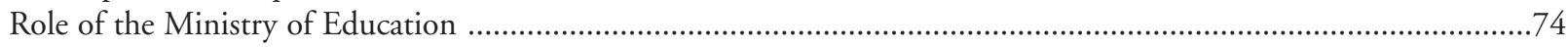

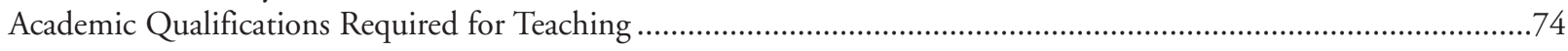

Role of the National Institute of Education in Teacher Training ..........................................................................75

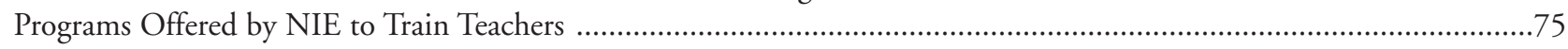

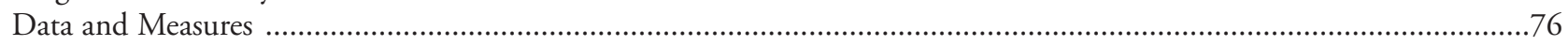

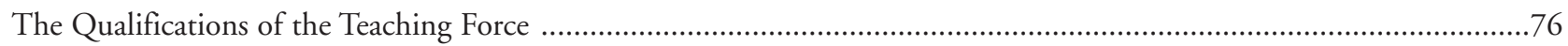

Levels of Qualifications of the Current Teaching Force in Singapore ..............................................................77

Secondary-Grade-Level Teachers' Subject Qualifications and Subjects Taught in School ......................................78

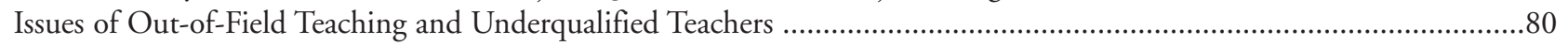

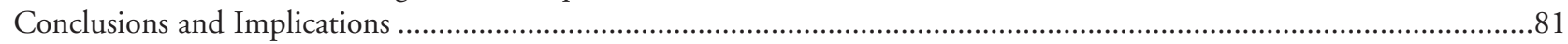

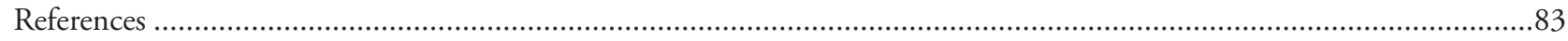

Chapter 7. The Qualifications of the Teaching Force in Thailand ............................................................................85

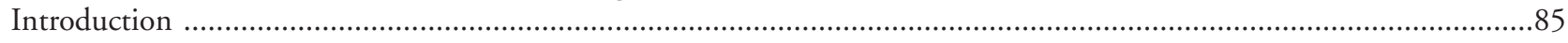

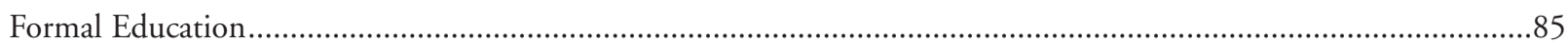

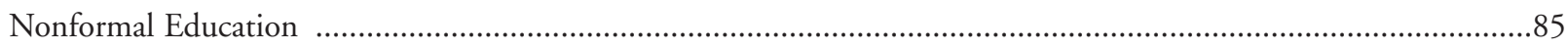

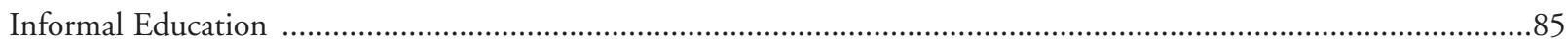

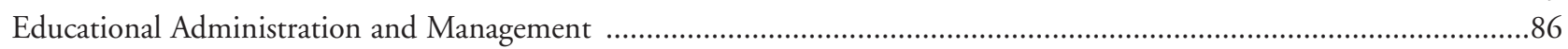

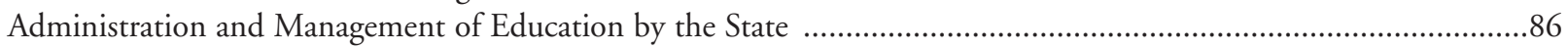

Administration and Management of Education by Local Administration Organizations .......................................87

Administration and Management of Education by the Private Sector.............................................................87

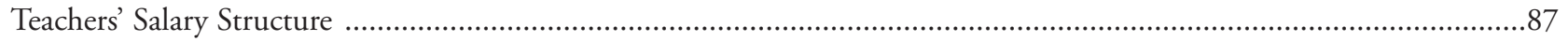




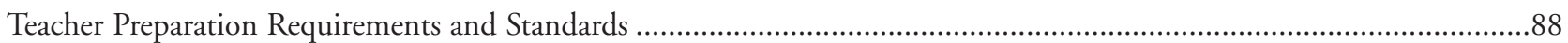

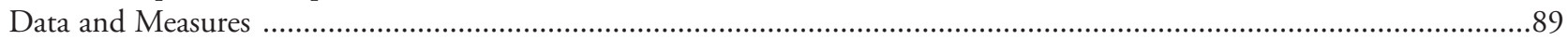

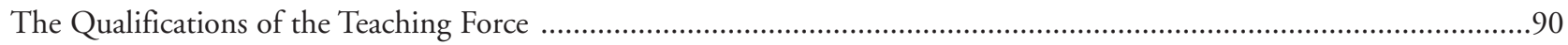

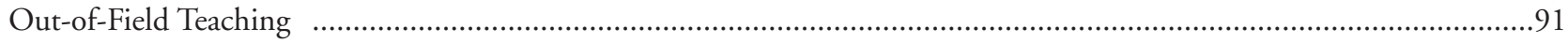

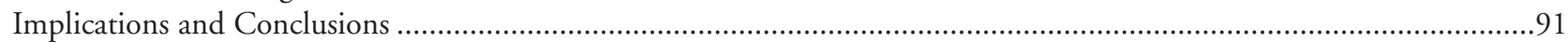

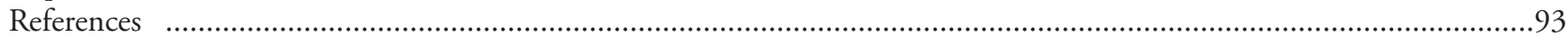

Chapter 8. The Preparation and Qualifications of the Teaching Force in the United States ....................................95

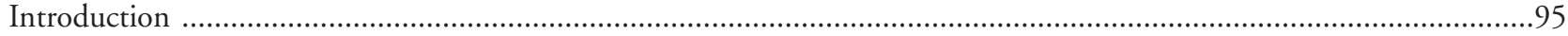

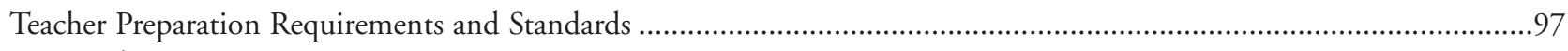

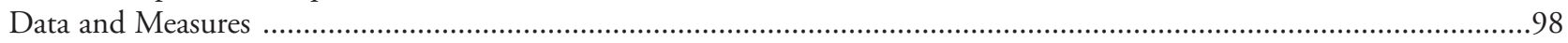

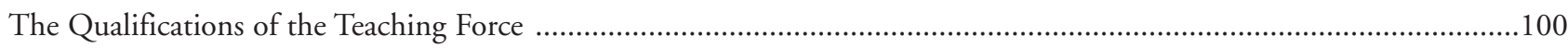

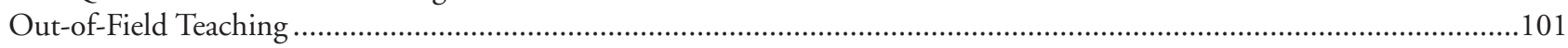

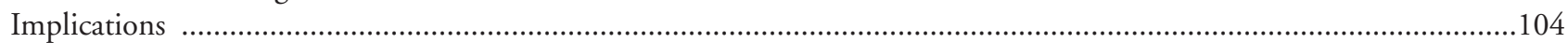

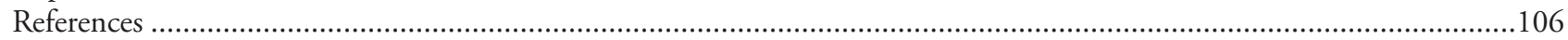




\section{List of Tables (by chapter)}

\section{Chapter 1}

Table 1 Average Mathematics and Science Achievement of Eighth-Grade Students for Nations Participating in the Third International Math and Science Study, 1999 ..........4

Table 2 Teacher Preparation Requirements and Standards, by System .8

Table 3 Percent School Teachers, by Highest Degree Earned, and by Teaching Certificate, by System. . .11 Table 4 Percent Secondary School Teachers in Four Academic Fields Without a Major in the Field Taught, by System. Table 5 Percent Secondary School Teachers in Four Academic Fields Without a Teaching Certificate or License in the Field Taught, by System

\section{Chapter 2}

Table 1 Numbers of Schools, Students, Teachers in China by Educational Level (2004).

Table 2 Numbers of Students, Graduates in China by Educational Level for Teacher Preparation, 2004 ...........20 Table 3 Qualified Rate of Record of Formal Schooling of Elementary, Junior Secondary, Senior Secondary Teachers in China by Type of Subject Taught, Type of School, in percentages, 2004 .22

Table 4 Percentage of Record of Formal Schooling of ELEMENTARY School Teachers in China, by Type of School , by Type of Subject Taught, 2004 .

Table 5 Percentage of Record of Formal Schooling of JUNIOR Secondary School Teachers in China, by Type of School, by Type of subject Taught, 2004.

Table 6 Percentage of Record of Formal Schooling of Senior SECONDARY School Teachers in China, by Type of School, by Type of subject Taught, 2004 ..........24 Table 7 Percentage of Different Types of Teachers in ELEMENTARY Schools in China, by

Type of School, 2004. .24

Table 8 Percentage of Different Types of Teachers in SECONDARY Schools in China, by Type of School, 2004

\section{Chapter 3}

Table 1 Number of Teachers in Hong Kong by Academic Qualifications/Training, 2005 . .34

Table 2 Number of Teachers by Academic and Teacher Training Qualifications, 2005 .34 Table 3 Distribution of Teachers by Subject Taught by Whether Teaching Out-of-field, 2005.

\section{Chapter 4}

Table 1 Types of Teacher's Certificates in Japan.

Table 2 Types of Teacher Training Programs in Japan .........44

Table 3 Highest Degrees Held by All Fulltime Teachers at Different Levels of Education in Japan (\%), 2004 ........46

Table 4 Percentage of Secondary School Classes

Taught by a teacher without a Certificate in the Field, by subject, 2004

Table 5 Percentage of Secondary School Teachers

Who Teach Classes Without a Certificate in the Field, by Subject, 2004 .47

Table 6 Percentage of Retired Teachers in Japan,

by Reason of Retirement, 2004 .48

Table 7 Percentage of School Teachers in Japan, by Monthly Salary (Unit: 10T=100,000), 2004 48

Table 8 Teachers' Perceptions of the Teaching Profession -

Percentage of those who answered "accurate" or "accurate to some degree".

Table 9 Teachers' perceptions of their work lives percentage of those who answered "Yes" or "Sometimes" ....49

Table 10 Determinants of the feeling of "authority of teachers is declining" .51

Table 11 Determinants of the feeling of "happy to have become a teacher" . .51

Table 12 Determinants of the feeling of "want to quit teaching".

\section{Chapter 5}

Table 1 Secondary Teacher Training Institutions with Freshmen Quota, 2005 ........................................................57

Table 2 Number of Vacancies and Employment Rate (Elementary), 1999-2005 ...................................................58

Table 3 Ratio Between Preparation and Employment, Secondary School Teacher, 1999-2005................................59

Table 4 Credit Hours Assigned to Curricular Domains in the Universities of Education .60

Table 5 Types and Required Credit Hours of Practice Teaching, University of Education...

Table 6 The Summary of Teacher Certification System......63

Table 7 Teachers' Academic Qualification, by Location,

School Level, and School Type, 2005

Table 8 Teaching Certificate Holders, 2005

Table 9 Percentage of Secondary Teachers in Korea in the Core Academic Fields Without a Teaching Certificate (Major) in the Field by

Type of School, 2005. 66 
Table 10 Percentage of Secondary Teachers in Korea in the Core Academic Fields Without a Teaching Certificate (Major or Minor) in the Field by Type of School, 2005.....67 Table 11 Percentage of Secondary Teachers in Korea in the Core Academic Fields Without a Teaching Certificate (Major, Minor or Minor Acquired through In-service Training) in the Field by Type of School, 2005.

Table 12 Percentage of Secondary Teachers in Korea in the Core Academic Fields Without an Undergraduate or Graduate Major in the Field by Type of School, 2005 ......68 Table 13 Percentage of Secondary Teachers in Korea in the Core Academic Fields Without an Undergraduate or Graduate Major or a Minor in the Field by Type of School, 2005

\section{Chapter 6}

Table 1 Summary Statistics of Teachers in Schools, 2006....76

Table 2 Percentage of Teachers in Singapore by Academic Qualification by Level of Schools, 2006

Table 3 Percentage of Vice-Principals and Principals in Singapore by Academic Qualification by Level of Schools, 2006 . .78

Table 4 Matching Teaching Subjects (Fields) with Subjects (Majors) offered by Universities and Curriculum Studies Assigned in NIE

Table 5 Summary Statistics on Teaching Subjects of Secondary School Teachers, 2005

\section{Chapter 7}

Table 1 New Teacher Classification Framework, 2004 ......88

Table 2 Previous Teacher Classification Framework.
Table 3 Percentage and Number of Elementary and Secondary School Teachers in Thailand by Highest Degree

Earned, and Types of School, ( Academic Year) 2004 ........89

Table 4 Percentage of Secondary Grade Level Teachers in Thailand in the Core Academic Fields Without an Undergraduate or Graduate Major or Minor in the Field, by Types of School, (Academic Year) 2004 .90

Table 5 Percentage of Secondary Grade Level Teachers in Thailand in the Core Academic Fields Without an Undergraduate or Graduate Major in the Field, by Types of School, (Academic Year) 2004. 90

\section{Chapter 8}

Table 1 Percentage of Elementary and Secondary School Teachers in the United States, by Highest Degree Earned, and by Highest Type of Teaching Certification or License, by Type of School, 2003-2004 101

Table 2 Percentage of Secondary Grade Level Teachers in the United States in the Core Academic Fields Without an Undergraduate or Graduate Major or a Minor in the Field, by Type of School, 1999-2000 102

Table 3 Percentage of Secondary Grade Level Teachers in the United States in the Core Academic Fields Without an Undergraduate or Graduate Major in the Field, by Type of School, 1999-2000 103

Table 4 Percentage of Secondary Grade Level Teachers in the United States in the Core Academic Fields Without a Teaching Certificate or License in the Field, by Type of School, 1999-2000

\section{List of Figures (by chapter)}

\section{Chapter 2}

Figure 1 China's Formal Educational System and Institutions.

\section{Chapter 5}

Figure 1 Elementary Teacher Training Institutions with Freshmen Quota, 2005

\section{Chapter 6}

Figure 1 Structure of Schooling in Singapore by Education Level, Typical Age and Years of Schooling, 2006

\section{Chapter 7}

Figure 1 The Thai Education System, 2006

\section{Chapter 8}




\section{About the Authors}

Richard M. Ingersoll is a Professor of Education and Sociology at the University of Pennsylvania in the United States. His research is concerned with the management and organization of elementary and secondary schools and the character and problems of the teaching occupation. He has published widely on the problems of teacher shortages and underqualified teachers.

Ding Gang is a Professor and Dean of School of Education Science, East China Normal University of the Peoples Republic of China. His research is concerned with the culture and social development of education and the change of teacher education and Teacher Professional Development. He has published numerous books and papers in the research areas.

Sun Meilu is a lecturer in the School of Education Science, East China Normal University of the Peoples Republic of China. Her research is concerned with vocational and adult education and human resources development. She has published numerous papers in the research areas.

Kwok Chan Lai is the Head of Strategic and Academic Planning at the Hong Kong Institute of Education and responsible for the Institute's academic planning, strategic planning and academic manpower planning. He had been the Head of Department of Social Studies of the Institute. His research interests include teacher education, teacher demand and supply, teacher professionalisation, environmental education and geographical education.
Hidenori Fujita, Ph.D., Professor, International Christian University (ICU)

He received his Ph.D. from Stanford University in 1978. Before moving to ICU in 2003, he had taught sociology of education as a professor at the University of Tokyo for 17 years and served as a dean of Graduate School of Education there from 2000 to 2003. $\mathrm{He}$ is Professor Emeritus of the University of Tokyo, member of Science Council of Japan and Chief Researcher of Japan Society for the Promotion of Science. He was the President of Japanese Association of Educational Sociology (2000-03) and served on the National Commission on Education Reform (2000) and Central Council for Education (2005).

Ee-gyeong Kim serves as the Director of Teacher Policy Research at the Korean Educational Development Institute. She has directed several research projects on teacher issues that have greatly influenced the formulation and implementation of teacher policies of the Republic of Korea. She has written books and articles on educational decentralization and on the quantity and quality of teachers. Her recent research interests include the evaluation and professional development of teachers and school administrators.
Steven K. S. Tan is associate professor and associate dean (professional development) of the National Institute of Education, Nanyang Technological University in Singapore. He has been involved in the teaching, development and review of both pre-service and professional development curriculum since 1995. His research interests are in educational reform and initiatives, and the induction and socialization of beginning teachers.

Angela F. L. Wong is an associate professor with the Learning Sciences and Technologies Academic Group, National Institute of Education (NIE), Nanyang Technological University. She also is the Associate Dean for Practicum and School Matters in the Foundation Programmes Office. She lectures in instructional technology and classroom management modules. Her research interests are in learning environments, instructional technology and practicum-related issues in teacher education.

\section{S. Gopinathan is Professor of}

Education at the National Institute of Education, Nanyang Technological University. His research interests are in teacher and higher education, and in education-society relationships. He is co-editor of the Asia Pacific Journal of Education and a founder member of the Educational Research Association of Singapore. 
Kim Chuan Goh is associate dean and has been involved in teacher education curriculum review and management, and student development and liaison since 2000 . He has written on teacher and teacher education issues. Currently he is leading a team to conduct "a longitudinal study of teacher preparation and professional development in Singapore", funded by the Ministry of Education.

Isabella Y. F. Wong is an Assistant Professor at the National Institute of Education, Nanyang Technological University. Her research interests are in teacher professional development and she has a long-standing interest in the preparation and induction of new teachers.

Kong Hong Ong is a Vice Principal in a secondary school in Singapore. His prior experience includes research and corporate planning at the Ministry of Information, Communication and the Arts, as well as education policy and human resource development at the Ministry of Education. During his stint in Personnel Division in the Ministry of Education, he worked closely with the National Institute of Education to look at the recruitment and training of teachers to meet the needs of Singapore schools.

Pruet Siribanpitak is an Associate Professor and Dean of the Faculty of Education at Chulalongkorn University in Thailand. He is also served as the President of the Thailand Education Deans Council. His research is concerned with the policy and development strategy of teacher education. He has published widely on the development strategy of teacher education and education for sustainable development.
Siriporn Boonyananta is the Deputy Secretary-General of the Education Council, Ministry of Education and Honorary Advisor to the National Parliament's Committee on Youths, the Disadvantaged, and Women's Affairs. Her vast experience comprises 20 years as curriculum development specialist at the Ministry of Education and parttime lecturer in graduate schools of many leading universities in Thailand. 


\section{Acknowledgements}

This report is based on research by the authors with the support of the Consortium for Policy Research in Education (CPRE) and funded by the Institute of Education Sciences, U.S. Department of Education, under Grant No. R308A960003. Opinions expressed in this publication are those of the authors and do not necessarily reflect the views of the Institute of Education Sciences, the U.S.

Department of Education, CPRE, or its institutional partners. 


\title{
CHAPTER 1
}

\section{A Comparative Study of Teacher Preparation and Qualifications in Six Nations}

\author{
Richard M. Ingersoll \\ University of Pennsylvania
}

\section{Introduction}

Across the educational systems of the world, few issues have received more attention in recent years than the problem of ensuring that elementaryand secondary-school classrooms are all staffed with adequately qualified teachers (Mullis, et al., 2000; OECD, 1994, 2005; Wang, et al., 2003). Even in nations where students routinely score high on international exams, the issue of teacher quality is the subject of much concern. This is not surprising. Elementary and secondary schooling is mandatory in almost all nations and children are legally placed in the care of teachers for a significant portion of their lives. It is widely believed that the quality of teachers and teaching are among the most important factors shaping the learning and growth of students. Moreover, this impact goes beyond student academic achievement. Across the world, observers routinely tie the performance of teachers to numerous, larger societal goals and problems-economic competitiveness and productivity, juvenile delinquency, moral and civic culture, and so on. In addition, the largest single component of the cost of education in any country typically is teacher compensation. Along with a general consensus among many nations that the quality of teachers and teaching is a vital resource, there is accordingly much concern surrounding how equitably this resource is distributed within educational systems. Indeed, some nations suffer from an apparent paradox-that despite an overall overproduction and oversupply of new teachers, there nevertheless appear to be substantial numbers of students without access to qualified teachers.

Such concern has resulted in a steady stream of commissions, reports, and studies all targeting teacher quality as one of the central problems facing school systems. In many nations this concern has resulted in new legislation and policy. Foremost among these have been widespread efforts to increase the entry standards and preparation requirements for teachers. Hong Kong, for instance, initiated in 1997 an "all graduate, all trained" policy requiring new primary- and secondary-school teachers to have bachelor's degrees and to be professionally trained. In Japan there has been an active reform movement to increase teacher preparation requirements and increase evaluation and accountability of teachers. In the United States this concern surfaced within a massive new piece of legislation in 2002, the federal law known as the No Child Left Behind Act, which in addition to new standards for student achievement, set a new and unprecedented goalto ensure that elementary and secondary students in the United States are all taught by highly qualified teachers. In addition to, or perhaps because of, recognition of its importance, the issue of teacher quality also is a source of debate and disagreement in many nations.

Perhaps nowhere is this debate more pronounced and more divisive than in the United States. In recent years, the quality of elementary and secondary teachers and teaching has been widely criticized in the United States, both by those inside and outside the educational sector (e.g., Levine, 2006). However, while there is widespread agreement that teacher quality is a problem in the United States, there is little consensus and much disagreement, often acrimonious, in regard to the sources and reasons behind the purportedly low quality of teaching in American schools and, hence, the best strategies to improve teacher quality.

One of the most prominent viewpoints in this debate holds that the problem of low-quality teaching can be traced to inadequate and 
insufficient pre-employment training and licensing or certification of prospective teachers. In this view, the preparation of teachers in college or university teacher education programs, and government certification standards, all too often lack adequate rigor, breadth and depth, resulting in high levels of underqualified teachers and low student performance. Accordingly, the solution, from this viewpoint, lies in making the entry and training requirements for teaching more restrictive, deeper and more rigorous. The examples this view looks to emulate are the traditional higher prestige professions, such as medicine, academia and law. To this group, the surest way to upgrade the quality of teaching is to upgrade the qualifications standards required of new teachers (see, e.g., National Commission on Teaching and America's Future 1996, 1997). Lowlevel standards and requirements for entry into teaching have long been considered a factor maintaining teaching as a low-status occupation and having a low level of professionalization.

On the other side of this debate are those who argue for deregulating entry into teaching. This viewpoint also holds that the quality of teacher education and certification is poor. But, rather than increasing requirements, this opposing view holds that entry into the teaching occupation already is plagued by unusually restrictive and unnecessarily rigid bureaucratic entry barriers (e.g., Finn, et al., 1999; Hanushek \& Rivkin, 2004; Ballou, 1996). From this viewpoint, traditional teacher preparation and state certification requirements, in particular, are akin to monopolistic practices. These critics argue that there is no solid empirical research documenting the value of such entry requirements. These regulations, they charge, are motivated less by an interest in protecting the public and more by a desire to protect the interests of those in the occupation. As a result, this view holds, large numbers of high-quality candidates are discouraged from getting into the occupation. By doing away with these regulatory impediments, this argument concludes, schools could finally recruit the kinds and numbers of candidates they deem best and this would solve the quality problems that plague teaching.

There are different variants of this deregulation perspective. One of the more popular variants favors a training model analogous to that utilized for entrance to postsecondary academic careers. The preemployment preparation of professors in the United States usually includes little formal training in pedagogical and instructional methods. Similarly, from this viewpoint, having an academic or subject-matter degree in a subject is sufficient to be a qualified school teacher in that subject. Content or subject knowledge-knowing what to teach-is considered of primary importance for a qualified teacher. Formal professional training in pedagogical and methodological knowledge and skills_-knowing how to teach-is considered less necessary or even irrelevant (e.g., Finn, et al., 1999).

Another variant of the deregulation perspective is motivated by concern for the demographic diversity of the elementary and secondary teaching force. From this viewpoint, teaching's entry requirements have resulted in reduced numbers of candidates from minority racial or ethnic groups entering the occupation, either because the requirements are themselves racially or ethnically biased, or because they screen out otherwise worthwhile candidates who are unable to pass over particular hurdles because of an underprivileged background (e.g., Villegas \& Lucas, 2004).

Proponents of variants of the deregulation perspective have pushed a range of initiatives, most of which involve a loosening of the traditional occupational entry gates. Among the most widespread of these reforms are alternative certification programs, whereby college graduates can postpone formal education training, obtain an emergency teaching certificate, and begin teaching immediately. It is important to note that proponents of these deregulation reforms claim the same rationale as proponents of upgrading existing entry standards and programs - the enhanced recruitment of high-quality candidates into teaching.

Because this debate is highly politicized and often acrimonious in the United States, advocates of one side or another are prone to exaggerated claims and counterclaims-making it difficult for neutral observers and policymakers to separate rhetoric from reality. One way to shed light is to place such debates and claims in context, and one useful context is crossoccupational. How does teaching, its entry requirements, and their value compare to those in other lines of work?

In the United States, teaching as an occupation has an unusually ambivalent character. Compared with other occupations and professions, teaching is relatively complex work, with relatively low pre-employment entry requirements, but nevertheless with relatively high scrutiny and skepticism of the requirements that do exist.

Among those who study work, organizations and occupations in 
general, teaching has traditionally been classified as a relatively complex form of work, characterized by uncertainty, intangibility and ambiguity and requiring a high a degree of initiative, thought, judgment and skill to do well (e.g., Bidwell, 1965; Lortie, 1975; Cohen, Raudenbush, \& Ball 2003). For example, in a classic comparative study of a number of occupations, Kohn and Schooler (p. 68, 1983) concluded that secondary teaching involved greater substantive complexity than the work of accountants, salespersons, machinists, managers and officials in service industries and in the retail trade.

Despite its complexity, from a cross-occupational perspective, teaching has long been characterized as an easy-entry occupation. Compared with other occupations and with the traditional professions in particular, teaching has a relatively low entry bar, and a relatively wide entry gate (Etzioni, 1969; Lortie, 1975; Ingersoll, 2001). Indeed, teaching is unusual in the United States in that most of those who desire to enter the occupation are free to do so-individuals choose the occupation, not vice versa. In contrast, the opposite prevails in many occupations and most traditional professions, such as law, medicine, engineering, architecture, dentistry, and academia. Especially in the latter career fields, entry is highly selective, occupational gatekeepers have a large say in choosing new members and not all who desire to enter succeed in doing so. Hence, placed in this context, entry to teaching does not appear especially restrictive or burdensome.

Finally, although teaching's entry training and licensing requirements are lower than those for many other lines of work in the United States, they are subject to far more skepticism and evaluation than for other lines of work. For most occupations and professions there has been little, if any, empirical research done assessing the value-added of practitioners having a particular credential, license or certification (Kane, 1994; American Educational Research Association/American Psychological Association/National Council on Measurement in Education, 1999). Such research can be difficult to undertake; if licensure is mandatory in an occupation, it is impossible to compare the performance of those licensed with those who are unlicensed. Nevertheless, occupational entry requirements, whether enforced by precedent or by law, are common. Indeed, it is illegal to do many lines of work, from plumbing and hairstyling to law and medicine, without a license. For example, almost all universities and colleges in the United States require a doctorate degree for full-time professorial positions. There is, of course, a growing secondary labor market in academia in which those without doctoral degrees are hired for various instructional or research positions, usually as nonpermanent employment. However, there are very few examples of a "professor effects" literature examining whether professors' qualifications have a positive effect on outcomes, such as student achievement, or on research quality (e.g., Pascarella \& Terenzini, 1991). In other words, in most occupations and professions in the United States, it typically is taken as a given that particular credentials are necessary to practice particular kinds of work.

In contrast, there is an extensive body of empirical research, going back decades, devoted to evaluating the effects of elementary and secondary teacher qualifications on teacher performance. Typically such studies try to assess the relationship between various measures of teacher preparation and various measures of student performance (for an earlier review see, e.g., Murnane \& Raizen, 1988). And, contrary to the skeptics, a number of studies have indeed found teacher education and preparation, of one sort or another, to be significantly related to increases in student achievement. This is a telling finding given the widespread criticism from both insiders and outsiders that teacher education is of low quality in the United States. For example, in a review of 60 empirical studies on the effects of teacher education, Greenwald, Hedges, and Laine (1996) concluded that teachers' degree levels consistently showed "very strong relations with student achievement ..." in "a wide variety of studies over a three decade period" (pp. 284-285). Some studies have looked closely at the amount and effects of subject-specific teacher education. For example, in a multilevel analysis of data from the 1992 National Assessment of Educational Performance (NAEP), Raudenbush, Fotiu, and Cheong (1999) found teacher education in mathematics (as measured by a major in math or in math education) to be "consistently positively and highly significantly related to math proficiency" in eighth-grade students. Similarly, a recent analysis of 2000 NAEP data found that eighth-grade students whose math teachers had a regular teaching certificate in math, or had a major or minor in math or math education scored significantly higher on the eighth-grade math test (Greenberg, Rhodes, Ye, \& Stancavage, 2004).

Accurately isolating and capturing the effects of teacher's qualifications on their students' achievement is difficult, however, and 
not surprisingly, the results of such research are, at times, mixed and contradictory. Moreover, there also are large gaps in this research (for a recent review, see Allen, 2003), further fueling the ongoing debate and fostering a large interest in further pursuit of this line of research. But, placed in a crossoccupational context, the mixed and limited quality of research documenting the value of entry requirements for teaching is not unusual; what is unusual is the existence of any such empirical research at all.

While perhaps more extreme and visible in the United States than other nations, similar concerns and debates have been occurring across the world. Hence, besides adopting a cross-occupational perspective, another way to shed light and place such debates and issues in context is through cross-national comparisons. Policy research can provide a useful function by comparing teaching's entry and training requirements among different countries. How do the qualifications of teachers differ between nations? This is the subject of this study.

\section{The Research Project}

The objective of this report is to present the results from a collaborative, comparative study that sought to address some of the above issues by examining the preparation and qualifications of elementary and secondary teachers in six nations and one autonomous region: China, Hong Kong , Japan, South Korea, Singapore, Thailand, and the United States. This project was begun in 2003 under the auspices of the larger Eight Nations Educational Research Program, a consortium devoted to comparative education research based at the University of Pennsylvania since 1993 and directed by Susan Fuhrman.

The selection of the seven systems in this study was not a result of any particular analytic strategy; their participation was simply a function of their membership in the existing Eight Nations consortium. However, the seven educational systems in our study do represent a wide range, providing useful contrasts. On one end of the range lies Singapore, a small city-state with about 500,000 students enrolled in 360 elementary and secondary schools. On the other end lies China, with over 212 million students enrolled in 485,000 elementary and secondary schools. Our seven systems also represent a wide range in terms of international student performance

Table 1

Average Mathematics and Science Achievement of Eighth-Grade Students for Nations Participating in the Third International Math and Science Study, 1999'

\begin{tabular}{|c|c|c|c|}
\hline \multicolumn{2}{|l|}{ Mathematics } & \multicolumn{2}{|l|}{ Science } \\
\hline Nation & Score & Nation & Score \\
\hline Singapore & 604 & Chinese Taipei & 569 \\
\hline Korea, Republic of & 587 & Singapore & 568 \\
\hline Chinese Taipei & 585 & Hungary & 552 \\
\hline Hong Kong SAR & 582 & Japan & 550 \\
\hline Japan & 579 & Korea, Republic of & 549 \\
\hline Belgium-Flemish & 558 & Netherlands & 545 \\
\hline Netherlands & 540 & Australia & 540 \\
\hline Slovak Republic & 534 & Czech Republic & 539 \\
\hline Hungary & 532 & England & 538 \\
\hline Canada & 531 & Finland & 535 \\
\hline Slovenia & 530 & Slovak Republic & 535 \\
\hline Russian Federation & 526 & Belgium-Flemish & 535 \\
\hline Australia & 525 & Slovenia & 533 \\
\hline Finland & 520 & Canada & 533 \\
\hline Czech Republic & 520 & Hong Kong SAR & 530 \\
\hline Malaysia & 519 & Russian Federation & 529 \\
\hline Bulgaria & 511 & Bulgaria & 518 \\
\hline Latvia & 505 & United States & 515 \\
\hline United States & 502 & New Zealand & 510 \\
\hline England & 496 & Latvia & 503 \\
\hline New Zealand & 491 & Italy & 493 \\
\hline Lithuania & 482 & Malaysia & 492 \\
\hline Italy & 479 & Lithuania & 488 \\
\hline Cyprus & 476 & Thailand & 482 \\
\hline Romania & .472 & Romania & 472 \\
\hline Thailand & 467 & Israel & 468 \\
\hline Israel & 466 & Cyprus & 460 \\
\hline Tunisia & 448 & Jordan & 450 \\
\hline Turkey & 429 & Iran, Islamic Republic of & 448 \\
\hline Jordan & 428 & Indonesia & 435 \\
\hline Iran, Islamic Republic of & 422 & Turkey & 433 \\
\hline Indonesia & 403 & Tunisia & 430 \\
\hline Chile & 392 & Chile & 420 \\
\hline Philippines & 345 & Philippines & 3.45 \\
\hline Morocco & 337 & Morocco & 323 \\
\hline South Africa & 275 & South Africa & 243 \\
\hline Average of 38 nations & 487 & Average of 38 nations & 488 \\
\hline
\end{tabular}


assessments. Students from a number of the Asian systems in our study, such as Singapore, Japan, Korea, and Hong Kong, typically perform well above average on most international assessments in math, science and reading literacy. In contrast, students from Thailand often perform below average on international assessments in math and science. For instance, as shown in Table 1, data from the Third International Math Science Study (TIMSS) on eighth-grade science and math student performance indicate four of our systems (Japan, Singapore, Hong Kong, and Korea) are well above average, while Thailand is below average. U.S. students typically perform slightly above average. But, there are exceptions to the latter. For instance, in the Progress in International Reading Literacy Study, fourth-grade American students perform better than students in almost all of the other 34 nations tested, including Hong Kong and Singapore (Mullis, et al., 2003).

Our study was undertaken by a team of scholars and senior education officials. Members of the project team were Richard Ingersoll and Rebecca Maynard of the University of Pennsylvania in the United States; Ding Gang of East China Normal University in Shanghai, China; Kwok Chan Lai of the Hong Kong Institute of Education; Hidenori Fujita of the International Christian University in Tokyo, Japan; Ee-gyeong Kim of the Korean Educational Development Institute, Seoul, Korea; Steven Tan and Angela F. L. Wong of the National Institute of Education, Nanyang Technological University, Singapore, Ong Kong Hong, of the Ministry of Education in Singapore; Pruet Siribanpitak of Chulalongkorn University in Bangkok, Thailand and Siriporn Boonyananta of the Office of The Education Council in
Thailand.

Team members met four times in the course of this project. A first meeting was held in Philadelphia, sponsored by the University of Pennsylvania, in November, 2003. A second meeting was held in Shanghai, sponsored by the East China Normal University, in June, 2004. A third meeting was held in Tokyo, sponsored by the International Christian University, in March, 2005. A fourth meeting was held in Bangkok, sponsored by the Thai Ministry of Education, in November, 2005. Meetings focused on determining the project objectives, defining common measures and methods, and working out the all important issues of data and indicator comparability. Data collection, analysis and writing for each system proceeded throughout the entire project.

Unlike other recent cross-national teacher studies, this project adopted a relatively specific focus on one key issue linked to the performance and quality of teachers-the qualifications and preparation of teachers. Our objective was not to assess or to evaluate the links between teacher qualifications, teaching quality, and student achievement. We did not seek to prove that the qualifications required of teachers in any system are, or are not, beneficial or do, or do not, add value. Our study began with the premise, widely shared among the nations involved, that teacher qualifications are important. But, we did not presume a particular definition of a qualified teacher. Our objective was to compare how each system itself defines teacher qualifications and standards and then to address the question: how well are the different educational systems succeeding in ensuring all students are taught by qualified teachers? The study addressed this overarching issue by examining comparative data from each of the seven educational systems on three specific sets of research questions:

\section{1.) What are the Preparation Requirements and Standards to Become a Teacher?}

In each system, what are the requirements to become a teacher and do they differ according to grade level? Do candidates need to complete both educational and professional preparation requirements? The former refers to the general level of post-secondary education - the courses and degrees_required of teaching candidates. The latter refers to occupation-specific or professional preparation and training requirements-the subject coursework, pedagogical coursework, practice teaching, and tests-for those entering teaching. Are teachers normally required to have completed a baccalaureate degree? Are teachers normally required to obtain some kind of government-issued teaching certificate or license? What are the criteria and requirements to obtain a certificate or license? Is some kind of testing of prospective teachers involved? What level of government decides on the pre-employment education and training requirements for elementary-level and secondarylevel teachers? Is decision-making for each educational system, in general, and for teacher policy, in particular, centralized or decentralized? How many teacher preparation institutions are there in each system?

Regardless of such formal requirements, how selective and competitive is entry into the teaching occupation in each system? How does the caliber and ability of those entering teaching compare to those preparing for, or entering, other 
fields? How attractive is the job and career of teaching compared to other careers in each nation?

\section{2.) What are the Levels of} Qualifications of the Current Teaching Force?

What proportion of the existing teaching force is qualified, that is, what portion meets the above described requirements and standards? Is there a gap between the rule and the reality? What proportion of the teaching force holds a baccalaureate degree? What proportion holds a graduate-level degree, such as a master's degree or higher? What proportion holds a teaching certificate or license or the equivalent?

In addition, we were interested in understanding differences, inequities and gaps in teacher qualifications within and across the educational systems. Specifically, we sought to answer these questions: Are there differences in the proportions of teachers holding the above qualifications across different kinds of schools in each system? Is there a maldistribution of qualified teachers? Do teachers in schools serving higher-poverty or low income communities have fewer qualifications than teachers in schools in lower-poverty or higher-income areas? Do teachers in elementary schools have fewer qualifications than teachers in secondary schools? Do teachers in urban or rural schools have fewer qualifications than teachers in suburban schools?

\section{3.) What Proportions of Teachers are Not Qualified in the Subjects They Teach?}

Do schools in each system have difficulties ensuring that all classrooms are staffed with teachers qualified in the actual subject taught? Along with inadequate preparation, one possible source of underqualified teachers is the practice of out-of-field teaching or misassignment- - teachers assigned to teach subjects that do not match their fields of preparation (Ingersoll, 1999). This is a crucial factor because highly qualified teachers may actually become highly unqualified if, once on the job, they are assigned to teach subjects for which they have little background. Teachers prepared, for example, in social studies may be unlikely to have a solid understanding of math or how to teach it.

Our study tried to obtain data on levels of out-of-field teaching in each system and the extent to which these levels vary among different kinds of schools. In which educational systems does this problem exist? Are there differences, inequities and gaps in out-of-field teaching within and across the educational systems? Are there cross-school differences in the proportions of classes taught by teachers not holding qualifications in the field taught? Are classes in higher-poverty schools more likely to be taught by underqualified teachers than classes in lower-poverty schools? Are there differences according to whether the school is urban, rural or suburban? Finally, what are the reasons for out-of-field teaching in these systems? Why do some teachers end up teaching subjects for which they have little background preparation?

Our objective was to compare each educational system using these three sets of data indicators to understand each system's standards for teacher preparation and how well each system is succeeding in achieving a qualified teaching force and in ensuring all students are taught by qualified teachers.

\section{Data and Methods}

Our study addressed the above sets of research questions by collecting comparative data from each of the seven educational systems. We focused on elementary and secondary level teachers from both public and private schools. Briefly, the data sources for each system were:

China: China Education Yearbook 2005 and Educational Statistics Yearbook of China 2004.

The former is annually edited and issued by the Ministry of Education, and the latter is issued by the Department of Development and Planning of the Ministry of Education. The data on teachers' qualifications were drawn from school administrative records of all teachers in the nation.

Hong Kong: Statistics on Primary and Secondary School Teachers, 2004/05 published by the Education and Manpower Bureau of Hong Kong. Teacher statistics are collected yearly by the government through a Web-based e-services system through schools to all 50,000 primary and secondary teachers.

Japan: The data on teachers' qualifications were drawn from school administrative records compiled in 2004 by the Ministry of Education. The data on out-of-field teaching are drawn from the administrative records compiled for Nigata Prefecture by its Board of Education. (Japan has 47 prefectures, which are the equivalent of states.)

Korea: The data on teachers' qualifications were drawn from the 2005 Annual Report on Educational Statistics. This annual compilation of school administrative records is issued by the Korean Educational Development Institute and based on data collected by the Ministry of Education and Human Resources Development. The data on out-of- 
field teaching were obtained by a 2005 survey questionnaire sent to a nationally representative stratified sample of 2,000 secondary school teachers. The response rate was $71.2 \%$.

Singapore: Data on teachers are derived from the Education Statistics Digest 2006. These data are compiled by the Management Information and Research Branch, Planning Division, Ministry of Education and published in July each year. The data on teachers' qualifications were drawn from school administrative records.

Thailand: The data on teachers' qualifications were drawn from school administrative records compiled by the Office of Basic Education Commission of the Ministry of Education in academic year 2004 . The data on out-of-field teaching were from a 2004 survey of officials in the 175 local education service agencies in Thailand conducted by the Office of the Education Council of the Ministry of Education. The latter data for public schools were collected from $64 \%$ of the local service agencies; the data for private schools were collected from $37 \%$ of the local service agencies.

United States: The data come from the nationally representative Schools and Staffing Survey (SASS) conducted by the National Center for Education Statistics, the statistical arm of the U.S. Department of Education. This is the largest and most comprehensive source of information and data on teachers in the United States. The SASS data are collected from random samples stratified by state, sector, and school level. SASS is a large survey; in each cycle the sample sizes are about 5,000 school districts, 11,000 schools and 52,000 teachers. Data on teachers' qualifications were collected in 200304; data on out-of-field teaching were collected in 1999-2000.
For our set of questions on outof-field teaching, our project team encountered serious difficulties in obtaining measures that were defined in a sufficiently similar manner to make reasonable comparisons across systems. Hence, the data presented here on out-of-field teaching must be interpreted with caution. Previous studies have used a number of different measures of out-of-field teaching, representing a range of definitions and standards (Ingersoll, 1999). Some measures focus on whether teachers have a teaching certificate in the fields they teach; others focus on whether teachers have an undergraduate or graduate degree. Measures of out-of-field teaching also vary according to whether they choose to focus on the numbers of teachers out of field or the numbers of students exposed, according to which fields and subjects are examined, how those fields are defined and also according to which grade levels are investigated.

Our measures focus on teachers at the secondary level (grades 7-12 grades) who were departmentalized, that is, they teach the same subjects to different classes of students, rather than multiple subjects to the same students throughout the day. Moreover, we focus only on those teaching the four core academic subjects-first language, mathematics, science, and social studies/social science.

\section{We used two measures:}

- Percentage of secondary-level (grades 7-12) teachers in four core fields without an undergraduate or graduate major in the field.

- Percentage of secondary-level (grades 7-12) teachers in four core fields without a full teaching certificate or license in the field.
Below, this chapter summarizes the results from the study as a whole. Following this overview chapter, there are separate chapters for each of the seven educational systems. The latter chapters provide more detailed presentations on teacher preparation and qualifications in each system and more detailed information on the data sources and methods.

\section{Teacher Preparation Requirements and Standards}

\section{Governance}

In our study we found that decisionmaking and governance for our educational systems, in general, and for teacher policy, in particular, are highly centralized. In all but one of the seven systems in this study, the central or national government sets, oversees and implements qualifications and preparation standards for the teaching occupation (also see OECD, 1995, 1998).

The exception to this centralization of teacher policy and governance is the United States, though there has been a steady increase of federal involvement in education over the past half century. This culminated in the $2002 \mathrm{No}$ Child Left Behind Act-the largest and most comprehensive federal educational reform effort to date. This trend toward centralization and consistency clashes with a historic tradition of decentralization and local control of education and as a result, the education system in the United States is in a state of flux. Nevertheless, and despite these changes, the U.S. educational system remains in many ways relatively decentralized compared with other nations. It is, for example, the responsibility of each of the 50 individual states to regulate entry 
into the teaching occupation in their respective state school systems, and the states have retained wide latitude in how they interpret and implement the teacher quality regulations of the central government. As a result, the scope and content of the requirements to become a teacher vary widely among the states.

Like the United States, most of the Asian nations have three or four tiers of educational governancenational, regional, local and school levels-but in those countries, unlike the United States, the national government dominates teacher-policy decision-making. As a result, the scope and content of official governmental requirements to becoming a teacher are highly consistent across regions and localities within each system. At one end lies Singapore with a central Ministry of Education that sets all teacher policy and has one teacher training institution that produces virtually all of Singapore's teachers. Although vastly larger, China also has a highly centralized system that dominates teacher-policy decisionmaking across the nation, with the exception of Hong Kong. As noted above, Hong Kong is considered a special semi-autonomous region in China and has its own internally centralized educational system.

The number of teacher-training schools, colleges or institutions in each system is telling: Singapore has one; Hong Kong has four; Thailand has 56 , Korea has 381, China has 618, Japan has 850 . The United States stands out with the highest1,206 - almost double that of China, despite having about one quarter the students.

\section{Education Requirements}

All of the educational systems, regardless of their degree of centralization, require prospective teachers to complete both educational and professional preparation requirements.

On the issue of education requirements, a four-year bachelor's or undergraduate degree is typically the standard for all of the systems. But, the different systems vary both within and across as to the level and years of education required, as shown in the column in Table 2 on minimal years of post-secondary education. In Hong Kong, teachers can gain entry with the equivalent of a two-year sub- or associate degree. In two systems-China and Singapore- the education required of elementary teachers is lower than that for secondary teachers-although in both

Table 2

Teacher Preparation Requirements and Standards, by System.*

\begin{tabular}{|c|c|c|c|c|c|c|c|c|}
\hline & \multicolumn{4}{|c|}{ Educational Qualifications } & \multicolumn{4}{|c|}{ Professional Qualifications } \\
\hline & $\begin{array}{c}\text { High } \\
\text { School } \\
\text { Diploma }\end{array}$ & $\begin{array}{l}\text { Associate or } \\
\text { Sub-Degree }\end{array}$ & $\begin{array}{l}\text { Bachelor's } \\
\text { Degree }\end{array}$ & $\begin{array}{l}\text { Minimum } \\
\text { Years Post- } \\
\text { Secondary } \\
\text { Education }\end{array}$ & $\begin{array}{c}\text { Subject-Area } \\
\text { and } \\
\text { Pedagogy }\end{array}$ & $\begin{array}{c}\text { Certification } \\
\text { and/or } \\
\text { License }\end{array}$ & $\begin{array}{c}\text { Test } \\
\text { or Exam }\end{array}$ & $\begin{array}{l}\text { Training } \\
\text { During } \\
\text { or After } \\
\text { Degree }\end{array}$ \\
\hline \multicolumn{9}{|l|}{ China } \\
\hline Elementary & $\mathrm{X}$ & & & 0 & $\mathrm{X}$ & $\mathrm{X}$ & $\mathrm{X}$ & Both \\
\hline L. Secondary & & $\mathrm{X}$ & & 2 & $\mathrm{X}$ & $\mathrm{X}$ & $\mathrm{X}$ & Both \\
\hline U. Secondary & & & $\mathrm{X}$ & 4 & $\mathrm{X}$ & $\mathrm{X}$ & $\mathrm{X}$ & Both \\
\hline \multicolumn{9}{|l|}{ Hong Kong } \\
\hline Elementary & & $\mathrm{X}$ & & $2-4$ & $\mathrm{X}$ & & & Both \\
\hline Secondary & & $\mathrm{X}$ & & $2-3$ & $\mathrm{X}$ & & & Both \\
\hline \multicolumn{9}{|l|}{ Japan } \\
\hline Elementary & & & $\mathrm{X}$ & 4 & $\mathrm{X}$ & $\mathrm{X}$ & $\mathrm{X}^{*}$ & Both \\
\hline Secondary & & & $\mathrm{X}$ & 4 & $\mathrm{X}$ & $\mathrm{X}$ & $\mathrm{X}^{*}$ & Both \\
\hline \multicolumn{9}{|l|}{ Korea } \\
\hline Elementary & & & $\mathrm{X}$ & 4 & $\mathrm{X}$ & $\mathrm{X}$ & $\mathrm{X}^{*}$ & During \\
\hline Secondary & & & $\mathrm{X}$ & 4 & $\mathrm{X}$ & $\mathrm{X}$ & $\mathrm{X}^{*}$ & Both \\
\hline \multicolumn{9}{|l|}{ Singapore } \\
\hline Elementary & & $\mathrm{X}$ & & 2 & $\mathrm{X}$ & $\mathrm{X}$ & & Both \\
\hline Secondary & & & $\mathrm{X}$ & $4+1$ & $\mathrm{X}$ & $\mathrm{X}$ & & Both \\
\hline \multicolumn{9}{|l|}{ Thailand } \\
\hline Elementary & & & $\mathrm{X}$ & $4+1,5$ & $\mathrm{X}$ & $\mathrm{X}$ & $\mathrm{X}^{*}$ & Both \\
\hline Secondary & & & $\mathrm{X}$ & $4+1,5$ & $\mathrm{X}$ & $\mathrm{X}$ & $\mathrm{X}^{*}$ & Both \\
\hline \multicolumn{9}{|l|}{ United States } \\
\hline Elementary & & & $\mathrm{X}$ & 4 & $\mathrm{X}$ & $\mathrm{X}$ & $\mathrm{X}$ & Both \\
\hline Secondary & & & $\mathrm{X}$ & 4 & $\mathrm{X}$ & $\mathrm{X}$ & $\mathrm{X}$ & Both \\
\hline
\end{tabular}

* Test or exam not required for license, but upon employment 
of these systems there is movement to bring elementary teachers up to par with secondary teachers. For instance, in China a high school diploma is the minimum level necessary to enter elementary teaching, while upper secondary teachers must have a four-year college degree. In Singapore an elementarylevel teacher can gain entry with the equivalent of a two-year sub- or associate degree, while at the secondary-level, Singapore requires teachers to complete a five-year program that includes a bachelor's degree plus a year of further coursework. In contrast, the other systems have similar degree standards for elementary and secondary. For instance, a five-year program is the standard in Thailand for both elementary and secondary teachers. In the United States, teachers at both levels are required to hold a bachelor's degree.

\section{Professional Training Requirements}

Beyond basic levels of education required, all of the systems have professional, or occupation-specific, requirements to enter teaching. Each educational system has different variations in the sequencing and organization of its professional preparation. One variation merges professional preparation and licensing within a bachelor degree program; hence, educational and professional preparation are completed concurrently. Another variation separates the two; the degree is completed first, with the professional preparation and certification subsequent. In the United States, the latter is referred to as a "fifth-year program" - a post-baccalaureate oneyear teacher-preparation program leading to a teaching certificate. But only two systems - the United States and Hong Kong-have what is referred to as alternative certification routes into teaching, where candidates are not required to have completed professional preparation prior to employment, and where, for instance, the uncertified can begin teaching before or during their preparation and training.

All of the systems, with the exception of Hong Kong, require candidates to obtain a governmentissued certificate or license signifying that a candidate has completed required professional preparation and training. Interestingly, in all systems the professional preparation requirements include both subjectmatter and pedagogical preparation-expertise in both the "what" and the "how" of teachingis required. In all of the systems, professional preparation includes a period in the field of supervised practice or student teaching prior to employment. As a result, in none of these systems do the rules stipulate that those with only a subject-matter degree (e.g., a degree in mathematics) are qualified to teach. Also, all of the systems with the exception of Hong Kong and Singapore require some kind of exam or test for prospective teachers. In some systems, these tests are administered as part of a teacherpreparation program; in others, they are administered by the school upon employment.

Again, because of its unusually decentralized character, there is some cross-state variation in these patterns in the United States. The No Child Left Behind Act requires that all teachers be "highly qualified." The latter is defined as someone who has a bachelor's degree, who holds a regular or full state-approved teaching certificate or license and who is competent in each of the academic subjects they teach. But, the 50 individual states have leeway in the means by which teachers can establish "competency" in a subject. For example, some states require tests of prospective teachers while others do not, and the contents of tests vary, as do the minimum scores necessary to pass. Moreover, the federal requirements do not apply to teachers employed in private schools and some states themselves do not require teachers in the private sector to hold a state license or certificate. However, as will be shown later in the chapter on the United States, the majority of teachers in private schools do in fact hold a regular teaching certificate. This is an instance, as in Hong Kong, where the reality exceeds the rule; that is, the level of preparation of the teaching force is above the official minimum required (more on this point in a later section).

\section{Selectivity of Programs, Caliber of Candidates and Attractiveness of Careers}

Listing the educational and professional requirements to become a teacher does not tell us a great deal of the rigor of these requirements, nor of the quality of these qualifications. Hence, our team examined data, where available, on the selectivity and competitiveness of entry, on the relative caliber and ability of those who enter teaching, and on the attractiveness, status and prestige accorded to teaching compared to other occupations. In some cases our data sources were not highly comparable in the measures and metrics used and, hence, our conclusions are limited. But in general we found that the different educational systems varied dramatically in these areas.

In the United States the 
requirements to become an elementary or secondary-level teacher have never been considered especially rigorous, and teaching has long been characterized as a relatively noncompetitive, easy-in occupation. Compared with other occupations in the United States and, in particular with high-status professions, teaching has a relatively low entry "bar" and a relatively wide entry "gate" (Lortie, 1975). As measured by collegeentrance examination scores, those entering teaching in the United States tend to be in the average to low range compared with other college graduates (Henke, Chen, \& Geis, 2000). To facilitate entry, the states early in the last century created large numbers of low-cost, dispersed, and nonrigorous teacher-training institutions and colleges. Ease of access remains the case; as the data reported earlier show, the United States has far more teacher training institutions than any of the other nations in this study.

Moreover, compared with the more prestigious traditional professions, teaching has been considered a less attractive and less desirable line of work. This has been especially true for males; the majority of teachers are female. Historically female-dominated occupations have tended to have less prestige, lower pay and less authority (Hodson $\&$ Sullivan, 1995). Teachers rank in the middle range in surveys of occupational prestige, well below traditional higher-status professionals, such as physicians, scientists, engineers, architects, dentists and attorneys, and well above blue collar occupations such as, police, barbers, bakers, plumbers and carpenters. There also is a striking status hierarchy within the realm of teaching itself, broadly defined. At the low end are preschool and kindergarten teachers, then elementary teachers, followed by secondary-level teachers, and finally far above are those who teach in post-secondary institutions professors (Ingersoll, 2001).

Many Asian nations have a tradition of respect for teachers. However, like the United States many Asian systems have a status hierarchy within teaching, with elementary teachers at the low end, followed by secondary-level teachers, and professors at the high end. In Singapore, teacher-education students are among the top third in the nation academically. Relatively high salaries, comprehensive training, and full pay while undergoing training all make teaching an attractive career option in Singapore. In Hong Kong, teaching is ranked relatively high in occupational stature by senior-secondary school students-above accountants, engineers, scientists, doctors and artists (Lai, et al., 2005). However, the quality of new entrants to teaching has been a matter of concern in the Hong Kong. The occupation does not attract candidates with the highest academic achievement; the examination grades of new students admitted to teacher education programs in the comprehensive universities generally are lower than those admitted to other disciplines (University of Hong Kong, 2007).

In China, teachers also rank relatively high in surveys of occupational prestige-above, for example, fashion designers, corporate managers and mid-level military officers (Li, et al., 2004). However, because teachers' salaries are low in China relative to other occupations, and especially low in rural areas, the occupation is not as attractive as some others. In Thailand, teaching is not considered to be an especially attractive occupation. Although there have been efforts to upgrade teacher salaries, they have been low when compared with professions_-about $25 \%$ of physicians' and engineers' salaries. It is common in Thailand for teachers to work extra part-time jobs, resulting in inadequate attention to their teaching. As a result, among many of those enrolled in teacher education institutions in Thailand, teaching is a second career choice.

In Korea, teaching is a relatively sought-after occupation because of its job security and its high social status standing. Relatively competitive individuals aspire to enter teaching and the rate of teacher turnover is very low because most teachers remain in teaching until the point of retirement. In Japan, teaching is an attractive option to college students, is relatively well paid, enjoys respect, job autonomy, and a collaborative community with colleagues that affords chances to grow and develop as educators. Not surprisingly, turnover and quit rates have traditionally been low.

But in Japan and Korea as in the United States, teachers have come under increasing criticism in recent years (Fujita, 2000a; Ingersoll, 2003). A recent study of teachers' comparative status in Japan, China and the United Kingdom revealed that an overwhelming majority of teachers perceived their authority to be in decline. Moreover, less than half of teachers in Japan reported they enjoyed "high social status." This was far higher than in the United Kingdom where only 17\% reported this, but far lower than China, where fully $70 \%$ of teachers reported high social status (Fujita, 2006). 
Table 3

PERCENT School Teachers, by Highest Degree Earned, and by Teaching Certificate, by System.

\begin{tabular}{|c|c|c|c|c|c|c|c|}
\hline & \multicolumn{3}{|c|}{ Educational Qualifications } & \multicolumn{3}{|c|}{ Professional Qualifications } & \multirow{2}{*}{$\begin{array}{l}\text { Both Bachelor's } \\
\text { Degree and Full } \\
\text { Certification }\end{array}$} \\
\hline & $\begin{array}{c}\text { Less than } \\
\text { Bachelor's } \\
\text { Degree }\end{array}$ & $\begin{array}{l}\text { Bachelor's } \\
\text { Degree }\end{array}$ & $\begin{array}{l}\text { Master's } \\
\text { Degree or } \\
\text { Higher }\end{array}$ & $\begin{array}{c}\text { No } \\
\text { Cerifiication }\end{array}$ & $\begin{array}{l}\text { Less-than } \\
\text { Full } \\
\text { Certification }\end{array}$ & $\begin{array}{c}\text { Full } \\
\text { Certification }\end{array}$ & \\
\hline \multicolumn{8}{|l|}{ China } \\
\hline Elementary & 95 & 5 & 0 & 0 & 2 & 98 & 5 \\
\hline L. Secondary & 71 & 29 & .2 & 0 & 6 & 94 & 29 \\
\hline U. Secondary & 21 & 79 & 1 & 0 & 20 & 80 & 80 \\
\hline \multicolumn{8}{|l|}{ Hong Kong } \\
\hline Elementary & 27 & 73 & 7 & 5 & 0 & 95 & 70 \\
\hline Secondary & 8 & 92 & 25 & 5 & 0 & 95 & 88 \\
\hline \multicolumn{8}{|l|}{ Japan } \\
\hline Elementary & 15 & 82 & 3 & 0 & 15 & 85 & 85 \\
\hline Secondary & 3 & 82 & 15 & 0 & 3 & 97 & 97 \\
\hline \multicolumn{8}{|l|}{ Korea } \\
\hline Elementary & 14 & 70 & 16 & 0 & 0 & 100 & 86 \\
\hline Secondary & .5 & 70 & 29 & 0 & 0 & 100 & 99 \\
\hline \multicolumn{8}{|l|}{ Singapore } \\
\hline Elementary & 52 & 46 & 2 & 0 & 0 & 100 & 48 \\
\hline Secondary & 11 & 82 & 7 & 0 & 0 & 100 & 89 \\
\hline \multicolumn{8}{|l|}{ Thailand } \\
\hline Elementary & 8 & 88 & 4 & 0 & 8 & 92 & 92 \\
\hline Secondary & 2 & 65 & 33 & 0 & 2 & 98 & 98 \\
\hline \multicolumn{8}{|l|}{ United States } \\
\hline Elementary & 1 & 54 & 44 & 4 & 6 & 89 & 89 \\
\hline Secondary & 3 & 49 & 49 & 5 & 8 & 87 & 85 \\
\hline
\end{tabular}

\section{The Qualifications of the Teaching Force}

Interestingly, the actual levels of education and professional training of the teaching force in each system are not necessarily predicted by official standards. (see Table 3) In a number of systems, such as China, the official rules exceed the reality. Sometimes, this results because veteran teachers who were qualified at the time they first entered the classroom, do not meet newly upgraded standards.

On the other hand, in Hong Kong, reality exceeds the rule. While Hong Kong does not require entrants to hold a four-year baccalaureate degree, nevertheless most employed teachers do so. Sixty-six percent of elementary and $90 \%$ of secondary teachers hold a bachelor's degree or higher. Moreover, in Hong Kong the majority of teachers hold a teaching certificate, even though this is not required by law. There appear to be at least two incentives behind these high levels-credential-based salary incentives for teachers, and societal expectations and pressures on school administrators to hire university graduates, even if they cost more.

In the United States, reality exceeds the rule in some cases. Moreover, in other cases, it exceeds the rhetoric. As mentioned earlier, the majority of teachers in private schools hold a teaching certificate, even though one is not necessarily required. Moreover, over nine in 10 public school teachers hold a teaching certificate, even though the conventional wisdom, trumpeted by the media and school reformers, is that there are significant numbers of uncertified teachers, especially in schools serving low-income, highpoverty communities.

For most of the seven systems, there is an elementary-secondary gap in teachers' qualifications, parallel to the elementary-secondary gap in standards, as discussed in the previous section. Elementary teachers often are less likely to hold a baccalaureate degree or a master's degree than are secondary teachers. In contrast, at the secondary level in most of the systems, at least $90 \%$ of the teachers hold a bachelor's degree. For instance, in Singapore only 48 percent of elementary teachers have a bachelor's degree, while about $89 \%$ do in secondary schools. It is important to note that teachers in Singapore who do not have bachelor's degrees nevertheless are required to undertake substantial 
pedagogical training and content coursework in their teaching subjects. In China, there are large proportions of teachers, even at the lower secondary level, who do not hold a baccalaureate degree.

On the issue of professional requirements, in all of the systems the vast majority of teachers hold regular teaching certificates or licenses. But, again, there often is an elementary-secondary gap and currently in some nations, such as Singapore, there is a strong push to close the elementary-secondary qualifications gap. Interestingly, the gap does not always run the same direction. In Japan, there is a 12 percentage point elementarysecondary licensing gap, although this has been decreasing over time. In China, the elementary-secondary licensing gap runs the opposite way-elementary teachers are more likely than secondary teachers to hold a license.

Thailand and the United States represent exceptions - their data indicate that at both the elementary and secondary levels, most school teachers hold a baccalaureate degree, many hold a master's degree or higher, and most hold certificates. Indeed in each nation, elementary teachers actually are slightly more likely to hold certificates. Among the Asian nations, Thailand also stands out for its high level of degree holders at the elementary level.

For two of the systems (China, United States) we were able to obtain data on cross-school differences in some of the indicators in Table 3 to discern if there is a poverty gap in teachers' qualifications. The data from these two systems reveal distinct inequities in the qualifications of teachers accordingly to the poverty level of students. In each of these systems, students in poorer schools are less likely to be taught by teachers who hold a certificate and a higher degree. These data are displayed in the relevant chapters.

While providing a useful portrait of the basic education and training of the teaching forces across systems, it also is important to acknowledge that the measures of degrees and certificates illustrated in Table 3 tell us little of the quality of these requirements. Moreover, we do not have analogous national data on other indicators of quality and qualifications, such as teachers' exam or test scores. Hence, it is important to recognize there may be inadequacies or inequities not revealed by our data.

\section{Teaching Assignments and Out-of-Field Teaching}

\section{Overview}

Our study revealed dramatic differences across the educational systems in the extent to which there is the practice of out-of-field teaching-where teachers educated and trained in one field are assigned by school administrators to teach classes in another field.

The data in Tables 4 and 5 reveal large differences across the systems in the percentages of teachers assigned to teach classes in fields that do not match their educational background. The problem is most severe in the
United States. For example, as shown in Table 4, over one third of all those who teach secondary-school mathematics in the United States do not have a major in mathematics, mathematics education, or in related disciplines like engineering, statistics or physics. Likewise, over one third of all those teaching secondary-school English classes do not have a major in English or related subjects such as literature, communications, speech, journalism, English education, or reading education. Twenty-nine percent of all those teaching secondary-school classes in any science do not have a college major in any one of the sciences or in science education. As shown by comparing Tables 4 and 5, similar proportions are found in the United States when looking at those without a teaching certificate in the field, as opposed to those without a degree.

Thailand and Hong Kong also have some problems with out-of-field teaching. In Thailand, abut one quarter of those teaching math, social studies and Thai language do not hold majors in those fields. In Hong Kong, levels of out-of-field approach those in the United States. Almost one third of those teaching math and social science do not have a certificate in those fields.

In contrast, there appears to be almost no out-of-field teaching at the secondary level in Japan. Korea also

\begin{tabular}{|c|c|c|c|c|}
\hline & $\begin{array}{l}\text { Native } \\
\text { Language }\end{array}$ & Math & Science & $\begin{array}{l}\text { Social Science/ } \\
\text { Studies }\end{array}$ \\
\hline China & NA & NA & NA & NA \\
\hline Hong Kong & NA & NA & NA & NA \\
\hline Japan & NA & NA & NA & NA \\
\hline Korea & 3 & 2 & 26 & 3 \\
\hline Singapore & NA & NA & NA & NA \\
\hline Thailand & 24 & 26 & 15 & 26 \\
\hline United States & 35 & 38 & 29 & 30 \\
\hline
\end{tabular}




\section{Table 5 \\ PERCENT Secondary School Teachers in Four Academic Fields Without a Teaching Certificate or License in the Field Taught, by System. ${ }^{4}$}

\begin{tabular}{|lllll|}
\hline & $\begin{array}{l}\text { Native } \\
\text { Language }\end{array}$ & Math & Science & $\begin{array}{l}\text { Social Science/ } \\
\text { Studies }\end{array}$ \\
\hline China & NA & NA & NA & NA \\
Hong Kong & 15 & 29 & 17 & 28 \\
Japan & .3 & 1 & .2 & .5 \\
Korea & 2 & 10 & 23 & 2 \\
Singapore & NA & NA & NA & NA \\
Thailand & NA & NA & NA & NA \\
United States & 29 & 32 & 29 & 30 \\
\hline
\end{tabular}

has very low levels of out-of-field teaching, with one large exceptionscience. Over one fourth of those teaching science in Korea do not hold a degree in one of the sciences.

In the two systems (Korea, United States) where data comparing different types of schools are available on out-of-field teaching, clear inequities exist. Teachers in highpoverty schools are more likely to be out-of-field. Indeed, in the United States, the most glaring and prominent source of inadequate access to qualified teachers is not a lack of basic education or professional training of teachers, but rather the widespread practice of misassignment.

\section{Reasons for Out-of-Field Teaching}

There appear to be a variety of reasons for the levels of out-of-field teaching reported for these systems, some having to do with how these measures are defined.

For instance, one factor contributing to the high levels of out-of-field teaching in science in Hong Kong and Korea is the manner by which the field is defined-a narrower and more stringent definition of a qualified teacher than used in other data, such field teaching in science in Korea; $30 \%$ of lower secondary science teachers have no certificate in science, while this is true for only $16 \%$ of science teachers at the upper secondary level. In Korea, computerscience teachers often are assigned to teach science.

It also is true in the United States that teachers in the middle grade levels are routinely assigned to teach classes in multiple fields. It is common, for instance, for states to require teachers employed in middle schools (grades 5-8) to obtain a generalist degree or certificate in elementary education that emphasizes a broad background and does not require substantial specialization in any one subject. But, once employed, many such teachers are assigned to teach subjectmatter courses to classes of different students all of most of the day, as if they are departmentalized secondarylevel teachers. As a result, rates of out-of-field teaching are especially high at the middle-grade levels in the United States. However, in the U.S. data used in this analysis, we were able to focus solely on teachers employed in secondary schools and were able to exclude seventh- and eighth-grade teachers employed in middle or elementary schools. This exclusion was not possible in the Hong Kong data, hence, inflating their figures.

In the United States, the data indicate that out-of-field teaching to a large extent is a result of the manner in which schools are organized and teachers are managed. School-staffing decisions usually follow a top-down command model: these decisions are the prerogative of school administrators, and teachers typically have little say over their assignments. School administrators face the difficult task of providing an increasingly broad array of programs 
with limited resources, time, budgets, and teaching staff. But, within those constraints, administrators have an unusual degree of discretion, and there is little centralized regulation over how teachers are utilized once they are hired. In this context, administrators report that, from a managerial perspective, they find that assigning teachers to teach out of their fields often is more convenient, less expensive, and less timeconsuming than the alternatives.

For example, rather than hire a new part-time science teacher for two sections of a newly state-mandated science curriculum, an administrator may find it simpler to assign two English or social-studies teachers to cover the science sections. When faced with a tough choice between hiring an unqualified candidate for a mathematics teacher position or doubling the class size of one of the fully qualified mathematics teachers, a school administrator might opt for the former. If a full-time music teacher is under contract, but student enrollment is sufficient to fill only three music classes, the principal may find it both necessary and cost effective in a given semester to assign the music teacher to teach two classes in English, in addition to the three classes in music, in order to employ the teacher for a regular full-time complement of five classes per semester. If a school has three fulltime social-studies teachers, but needs to offer the equivalent of $31 / 2$ full-time positions, and also has more than enough full-time English teachers, one solution would be to assign one of the English teachers to teach both English courses and some social-studies courses.

From a managerial perspective, these choices may save time and money for the school, and ultimately for the taxpayer. From an educational perspective they are not cost-free, as they are among the largest sources of underqualified teachers in schools in the United States.

\section{Implications}

This study reveals both commonalities and differences in the preparation and qualifications of teachers among the seven systems we examined. A question, reasonable to ask, but difficult to answer, is which approach is best? Our objective, however, was not to try to identify any one approach as better than another. Nor did we seek to document the necessity or value of teacher preparation and qualifications. Our objective was to describe the pre-employment preparation and qualifications standards, as well as the educational and professional training levels of teachers in each system. Our larger goal was to address the question: how well are these different educational systems succeeding in ensuring all students are taught by qualified teachers? How can this study help understand where problems may lie in meeting these needs?

Comparative educational research can provide a useful function by placing educational systems in context. There are a variety of possible reasons why elementary and secondary classrooms sometimes may not be staffed by qualified teachers. If educational reform is to succeed in solving the problem of underqualified teachers, it must address the major sources of the problem. Misdiagnoses of the sources of the problem can result in misguided or inadequate solutions to the problem.

Our study suggests at least three possible sources of the problem of underqualified teachers. One possible cause lies in the pre-employment requirements and standards themselves. The depth, breadth and rigor of college or university teacher training and preparation requirements and of government licensing and certification standards are possible sources of inadequacies. In these cases, remedies must look to reform of institutional preparation programs or of government licensing requirements.

A second possible source of underqualified teachers lies in the failure of the teaching force to meet existing requirements and standards. This could be for a variety of reasons-including deficits in candidates' ability, education, preparation or training. Falling into this category are candidates who have not completed a required degree, lack adequate professional training, have not had adequate practice teaching, have not obtained a certificate or license, have not completed sufficient coursework in their major area of concentration, or are unable to pass required tests. Remedies must address the source of noncompliance with the standards and the reasons for gaps between rule and reality. Do those entering preparation institutions lack the ability to meet the requirements? Is the problem due to a qualification gap where an earlier generation of veteran teachers do not meet newly upgraded standards? Does the problem lie with the adequacy of preparation programs and institutions themselves? Do they offer inadequate curricula or support for their students? Does the source of the problem lie at the point of hiring and employment? Do schools hire candidates who do not meet the existing standards? If so, is this because of an inadequate supply of willing and able applicants at the prevailing wage, or because of inadequacies in the hiring process itself? 
A third source of underqualified teaching arises in how teachers are utilized once on the job-the problem of misassignment or out-of-field teaching. Again, remedies must address the actual source of noncompliance with the standards. Is the problem an inadequate supply of willing and able applicants, forcing those doing the hiring to accept underqualified candidates? Or does the problem lie in the way teachers, once on the job, are utilized in schools? If, for example, regardless of supply, many schools persist in assigning teachers to teach subjects that do not match their qualifications, then a close examination of the character of human-resource management in schools is necessary.

This summary chapter closes with a brief description of some possible implications of what we have found in this study relative to just one of the systems, that of the United States. Recent teacher policy and debate in the United States illustrates the importance of adequately understanding the source of the problem.

What counts as the optimal content and rigor of entry requirements for new teachers has been a great source of contention in the United States. On one side are those who argue that entry into teaching should be more highly restricted, as in the traditional professions. On the other side are those who argue that entry into the teaching occupation already is plagued by unusually restrictive and unnecessarily rigid bureaucratic entry barriers.

Compared with some other nations, the data reveal that entry into the teaching occupation in the United States does not appear to be especially restrictive, burdensome, rigorous, or difficult. The United
States has more teacher training institutions than the other systems and overall entry is not especially selective. Moreover, unlike most other systems, prospective candidates in the United States can choose from a range of alternative certification and entry routes. Requiring prospective teachers to have both subject-matter and pedagogical expertise, as is common in the United States, also is not unusual; indeed all of the systems we studied required both. Notably, some systems, such as Singapore, have lower degree requirements than the United States, especially at the elementary level. But, teaching is a far more attractive and well-paid occupation in Singapore and, as a result, entry is highly selective and preparation highly rigorous, without such requirements. This is consistent with another recent study that compared filters and requirements embedded in the process of becoming a teacher in across a number of countries, including Australia, England, Japan, Korea, Netherlands, Hong Kong, and Singapore and concluded that entry to teaching in the United States is relatively easy (Wang, et al., 2003).

Regardless of the rigor and adequacy of entry requirements and standards, a second source of problems is the failure of teachers to meet the standards-the gap between rule and reality. Policy debates in the United States have underscored the tension between the need to maintain adequate entry requirements and the need to ensure an adequate incoming supply of new teaching candidates, especially given the high levels of teacher turnover. At times this dynamic results in an apparent paradox where states develop more rigorous licensing criteria, while simultaneously passing legislation that waives the requirements to meet such criteria. In other words, policymakers at times have lowered the bar to increase supply.

One lesson to be gleaned is that attempts to upgrade entry requirements cannot be implemented unilaterally. Without also upgrading rewards to a commensurate level, such initiatives most likely will falter. Some historians have held that attempts to upgrade the caliber of teachers through more rigorous training and licensing standards or more selective entry gates often resulted in decreases in male entrants to teaching, who were more attracted to occupations with better rewards attached to rigorous standards (Strober \& Tyack, 1980). A policy solution to the dilemma of trying to ensure sufficient supply, without lowering the bar, would be to simultaneously upgrade the quality and attractiveness of the job.

Another factor behind difficulties in ensuring that teachers meet standards has do with the adequacy of the recruitment and hiring process in some U.S. schools. Several studies have concluded that the staffing problems plaguing some low-income districts, in particular, are exacerbated by inadequate human-resource departments and flawed hiring policies (Odden, Milanowski, \& Heneman, 2007). For instance, a study of four low-income urban districts in 2003 found that in each case there were more than enough qualified applicants to successfully fill existing vacancies. But, a cumbersome application process, layers of bureaucracy, inadequate customer service, poor data systems, late budget timetables, and senioritybased teacher transfer rules all undermined the ability of the districts to place qualified candidates in classrooms (New Teacher Project, 2004). 
Finally, a related problem of human-resource management is the practice of misassignment. In contrast to most of the other systems in this study, the data indicate that a major source of underqualified teaching in the United States is the administrative practice of out-of-field teaching assignments. The data show that compared with some of the other nations in this study, this practice is especially widespread in the United States and especially in those schools serving disadvantaged communities.

Understanding the reasons behind underqualified teaching is important because of the implications for solving the problem. Most contemporary teacher-reform initiatives in the United States, in focusing on upgrading the training requirements of teachers and teacher recruitment, have overlooked the impact of the organizational and occupational contexts within which teachers work. The data, however, indicate that solutions to the problem of underqualified teachers also must look to how schools are managed and how teachers are utilized once they are on the job. In short, recruiting thousands of new candidates and providing them with rigorous preparation will not solve the problem if large numbers of teachers receive assignments for which they are not prepared. 


\section{References}

Allen, M. (2003). Eight questions on teacher preparation: What does the research say? Denver, CO: Education of the States. Retrieved February 20, 2007, from www.ecs.org/tpreport.

American Educational Research Association, American Psychological Association, National Council on Measurement in Education.(1999).

Standards for educational and psychological testing. Washington, DC: author.

Ballou, D. (1996). Do public schools hire the best applicants? Quarterly Journal of Economics, 111(1), 97-133.

Bidwell, C. (1965). The school as a formal organization. In J.G. March (Ed.), Handbook of organizations (pp. 973 1002). Chicago: Rand McNally.

Cohen, D., Raudenbush, S., \& Ball, D. (2003). Resources, instruction and research. Educational Evaluation and Policy Analysis, 25(2), 119-142.

Etzioni, A. (Ed.). (1969). The semi professions and their organizations: Teachers, nurses and social workers (pp. 1-53). New York: Free Press.

Finn, C., Kanstoroom, M., \& Petrilli, M. (1999). The quest for better teachers: Grading the states. Washington, DC: Thomas B. Fordham Foundation.

Fujita, H. (2000a). Education reform and education politics in Japan. The American Sociologist, 31(3), 42-57.

Fujita, H. (1999, January 18-21). Choice, quality and democracy in education: A comparison of current educational reforms in the United
States, the United Kingdom and Japan, Paper presented at the international symposium on The Public and the Private in the United States sponsored by the Japanese Association for American Studies and the Japan Center for Area Studies of the National Museum of Ethnology, held in Osaka, Japan. Retrieved February 13, 2007 at http://www.childresearch.net/RESOUR CE/RESEARCH/2000/FUJITA/index. html

Fujita, H. (2006). Kyoiku-kaikaku no Yukue [Where is education reform going?]. Iwanami Shoten.

Greenberg, E., Rhodes, D., Ye, X., \& Stancavage, F. (2004). Prepared to teach: Teacher preparation and student achievement in 8th grade mathematics. Paper presented at the American Educational Research Association Annual Meeting, San Diego.

Greenwald, R., Hedges, L., \& Laine, R. (1996). The effect of school resources on student achievement. Review of Educational Research, 66, 361-396.

Hanushek, E. \& Rivkin, S. (2004). How to improve the supply of high quality teachers. In D. Ravitch (Ed.), Brookings papers on education policy (pp. 7-44). Washington, DC: Brookings Institution.

Henke, R., Chen, X., \& Geis, S. (2000). Progress through the pipeline: 1992-93 college graduates and elementary/secondary school teaching as of 1997. Washington, DC: National Center for Education Statistics.
Hodson, R. \& Sullivan, T. (1995). Professions and professionals. In The social organization of work (pp. 287314). Belmont, CA: Wadsworth.

Ingersoll, R. (1999). The problem of underqualified teachers in American secondary schools. Educational Researcher, 28(2): 26-37.

Ingersoll, R . (2001). The status of teaching as a profession. In J. Ballantine \& J. Spade (Eds.), Schools and society: a sociological approach to education ( pp. 115-129). Belmont, CA: Wadsworth Press.

Ingersoll, R. (2003). Who controls teachers' work?: Power and accountability in America's schools. Cambridge, MA: Harvard University Press.

Kane, M. (1994). Validating interpretive arguments for licensure and certification examinations. Evaluation \& The Health Professions, 17(2),133-159.

Kohn, M., \& Schooler, C. (1983). Work and personality. Norwood, NJ: Ablex

Lai, K.C., Chan, K.W., Ko, K.W., \& So, K.S. (2005). Teaching as a career: A perspective from Hong Kong senior secondary students. Journal of Education for Teaching, 31(3): 153168.

Levine, A. (2006). Educating school teachers. New York: The Education Schools Project. 
Li P., Li Q., \& Sun, L. (2004). Social stratification in China today. Beijing: Social Sciences Documentation Publishing House.

Lortie, D. (1975). School teacher. Chicago: University of Chicago Press.

Mullis, I., Martin, M., Gonzalez, E., Gregory, K., Garden, R., O'Connor, K. Chrostowski, S., \& Smith, T. (2000). TIMSS 1999 international mathematics report. IEA.

Mullis, I., Martin, M., Gonzalez, E., \& Kennedy, A. (2003). PERLS 2001 international report: IEA's study of reading literacy achievement in primary schools in 35 countries. IEA.

Murnane, R., \& Raizen, S. (1988). Indicators of teaching quality. In R. Murnane \& S. Senta, (Eds.), Improving indicators of the quality of science and mathematics education in grades K-12 (pp. 90-118).

Washington, DC: National Academy Press.

National Commission on Teaching and America's Future. (1996). What matters most: Teaching for America's future. New York: NCTAF.

National Commission on Teaching and America's Future. (1997). Doing what matters most: Investing in quality teaching. New York: NCTAF.

New Teacher Project. (2004). Missed Opportunities. New York: author.

Odden, A, Milanowski, A., \& Heneman, H. (in press). Policy and professionals: Commentary. In D. Cohen, S. Fuhrman, \& F. Mosher, (Eds.), The state of education policy research. Mahwah, NJ: Lawrence Erlbaum Associates.
Organization for Economic Cooperation and Cultural Development. (1994). Quality in teaching. Paris: OECD.

Organization for Economic Cooperation and Cultural Development. (1995). Decisionmaking in 14 OECD education systems. Paris: OECD.

Organization for Economic Cooperation and Cultural Development. (1998). Education at a glance: OECD indicators. Paris: OECD.

Organization for Economic Cooperation and Cultural Development. (1998). Education at a glance: $O E C D$ indicators. Paris: OECD.

Organization for Economic Cooperation and Cultural Development. (2000). Knowledge and skills for life: First results from $O E C D$ 's programme for international student assessment (PISA). Paris: OECD.

Organization for Economic Cooperation and Cultural Development. (2005). Teachers matter: Attracting, developing and retaining effective teachers. Paris: OECD.

Pascarella, E., \& Terenzini, P. (1991). How college affects students: Findings and insights form twenty years of research. San Francisco: Jossey-Bass.

Raudenbush, S., Fotiu, R., \& Cheong, Y. (1999). Synthesizing results from the trial state assessment. Journal of Educational and Behavioral Statistics, 24(4), 413-438.
Strober, M., \& Tyack, D. (1980). Why do women teach and men manage? Signs, 5, 499-500.

University of Hong Kong. (2006). JUPAS admission grades. Retrieved January 6, 2007, from http://www.hku.hk/admission/jupasgrades.htm

Villegas, A., \& Lucas, T. (2004). Diversifying the teacher workforce. In M. Smylie \& D. Miretzky, (Eds.), 103rd yearbook of the national society for the study of education. Chicago: National Society for the Study of Education.

Wang, A., Coleman, A., Coley, R., \& Phelps, R. (2003). Preparing teachers around the world. Princeton, NJ: Educational Testing Service. 


\title{
CHAPTER 2
}

\section{The Qualifications of the Teaching Force in China}

\author{
Ding Gang and Sun Meilu \\ East China Normal University
}

\section{Introduction}

Governance of education is highly centralized in China. Traditionally, the provision of educationschooling - is seen as the function of the national government. From 1949 forward, virtually all schools were designated as public. With the reforms of recent years, private schools are permitted and their opening has been encouraged. However, public schools still occupy the largest proportion of all educational institutions. Moreover, with regard to teacher regulation, even private schools are under the strict control of the central and local governments.

As Figure 1 shows, basic education in China is structured as a 6-3-3 system, representing six years of primary education, three years of junior-secondary and three years of senior-secondary education. Primary and junior-secondary education is mandatory. In the category of seniorsecondary education, besides the regular schools, there also are vocational schools, technical schools and other specialized secondary schools. Table 1 shows the number of schools, students, teachers by educational level in 2003.

In China, three types of institutions educate students to be teachers. As Figure 1 shows, the first type is known as the secondary teachers school, which is actually a
Figure 1

China's Formal Educational System and Institutions

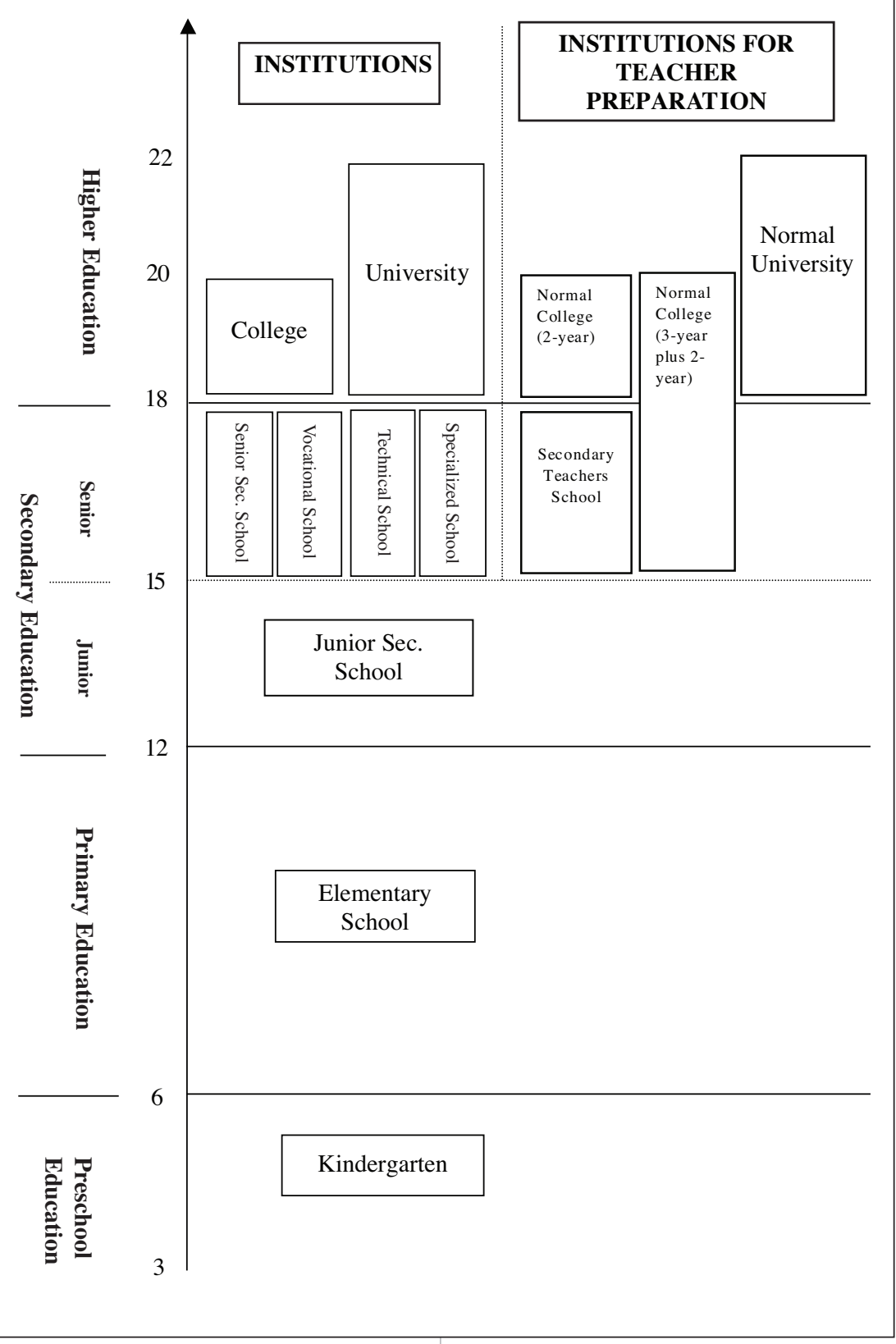


Table 1

Numbers of Schools, Students, Teachers in China by Educational Level (2004) ${ }^{1}$

\begin{tabular}{|lrrrr|}
\hline & Schools & Students & Teachers & $\begin{array}{r}\text { Student- } \\
\text { Teacher } \\
\text { Ratio }\end{array}$ \\
\hline Total & 484,953 & $212,474,942$ & $10,929,021$ & $19.4: 1$ \\
\hline $\begin{array}{lrrr}\text { Primary Education } \\
\text { Elementary schools }\end{array}$ & 394,183 & $112,462,256$ & $5,628,860$ & $20.0: 1$ \\
\hline Junior Secondary Education & & & & \\
Junior schools & 63,060 & $64,750,006$ & $3,476,784$ & $18.6: 1$ \\
\hline Senior Secondary Education & & & & \\
Senior schools & 15,998 & $22,203,701$ & $1,190,681$ & $18.6: 1$ \\
Specialized schools & 3,047 & $5,544,733$ & 197,084 & $28.1: 1$ \\
Vocational schools & 5,781 & $5,169,246$ & 270,612 & $19.1: 1$ \\
Technical schools & 2,884 & $2,345,000$ & 165,000 & $14.2: 1$ \\
\hline
\end{tabular}

'China statistics yearbook 2004.

a. Schools include all the public and non-state/private schools.

\begin{tabular}{|c|c|}
\hline \multicolumn{2}{|c|}{$\begin{array}{l}\text { Table } 2 \\
\text { Numbers of Students, Graduates in China by Educational Level for Teacher } \\
\text { Preparation, } 2004^{2}\end{array}$} \\
\hline Students & Graduates \\
\hline Secondary Teachers School & 750,362 \\
\hline Sub-degree & 190,721 \\
\hline Undergraduate & 194,019 \\
\hline
\end{tabular}

${ }^{2}$ China education yearbook 2005.

specialized secondary school that prepares students to be teachers in primary and pre-school education. These schools issue a high school diploma. The second is the normal college, which recruits graduates from senior-secondary schools for two-year higher-education programs and also recruits graduates from junior-secondary schools for threeyear senior-secondary education plus two-year higher-education programs. The normal college is a kind of junior college that issues a subdegree, which documents that a graduate has successfully completed two years of higher education. Normal colleges prepare teachers for junior-secondary schools. The third type is the normal university, which is a four-year undergraduate university that issues bachelor's degrees and prepares teachers for senior-secondary schools. All these institutions are public schools. Students enrolled are called normal education students, and all of them get special scholarships. In 2003, there were 430 secondary teachers schools and 188 normal colleges and universities. Table 2 shows the number of students and graduates for teacher preparation by educational level in 2003.

Recently, some other education institutions such as comprehensive universities have been permitted to set up teacher-education courses, and individuals also can apply for the Teacher Qualification Certificate, regardless of which type of teaching school they attended, thus making the teacher-education system more open. But the three types of teachereducation institutions mentioned above remain the main sources of graduates for primary and secondary teaching ranks.
The central government of China controls and directs teacher education through legislation and regulation, making basic policies, standards and plans, setting up special funds and projects, etc. Under the central government's direction, local governments have primary responsibility for running the teacher education system.

In general, the teaching force remains undersupplied and in a state of shortage in China, especially in the western, less-developed and rural areas. Table 1 shows that studentteacher ratios in elementary, juniorsecondary and senior-secondary schools are comparatively high, being 20.0:1, 18.6:1 and 18.6:1 respectively. As articulated in the national education-development planning objective, gross enrollment in senior-secondary education ${ }^{3}$ is to expand from $42.1 \%$ in 2003 to $60 \%$ by 2010 . If that goal is achieved, researchers estimate the gap between demand and supply of seniorsecondary school teachers to grow to 1.16 million (Project Team of China's Education and Human Resource Development, 2002). The current shortage is severe, with principals and headmasters employing many people who are not very qualified to fulfill teaching tasks.

China maintains a tradition of holding teachers in high regard. From long ago, teachers have enjoyed relatively high occupational prestige. According to a survey conducted in Beijing in 1997-1998, primary and secondary teachers rank 29th in prestige, above middle-level officers, fashion designers and corporation managers (Li Peilin, et al., 2004). However, teachers' earnings are not relatively high in China, and in some rural areas teachers (especially those

${ }^{3}$ Gross enrollment of senior-secondary education is the number of students enrolled in senior-secondary education, as a percentage of the population in the age group from 15 to 18 for this educational level. 
who are substitute teachers) with some frequency fail to receive their salaries in due time. This influences the attractiveness of teaching as an occupation and makes a lot of teachers quit their jobs to seek better careers. In recent years, this situation has improved somewhat.

\section{Teacher Preparation Requirements and Standards}

Besides Hong Kong, there are 27 provinces and four cities directly under the central government. The preparation requirements and standards imposed on teacher candidates are established by the central government although it is left to the 31 provinces and cities to regulate the entry criteria. Since 1993, the central government has promulgated Law of Teachers (1993), Regulations for Qualification of Teachers (1995), and Implementation of Regulations for Qualification of Teachers (2000) regulating the teacher education process. A teacher candidate initially needs to obtain the teaching certificate, under the principles articulated below.

First, entrants should have the relevant degree or certificate:

- To become a primary-school teacher, a secondary-teachers school certificate (high school diploma) or above;

- To become a junior-school teacher, a normal college certificate (subdegree) or above;

- To become a senior-school teacher, a four-year bachelor's degree or above.

Second, entrants should have passed the Mandarin language test. According to the standards established by the National Mandarin Test Committee, an examinee's capabilities of speaking and hearing Mandarin - the official language for teaching — can be ranked. There are three levels, with each level divided into two classes, so there are six grades in all. The top level is Class One Level One, followed by Class Two Level One, Class One Level Two, and so on, with the lowest level of competency being Class Two Level Three. To pass, an entrant should attain Class Two Level Two or above, meaning an error rate on the test of less than $20 \%$. In dialect-mixed areas, a testtaker should reach Class One Level Three or above, which means the rate of making errors on the test should be less than $30 \%$.

Third, entrants should have obtained the professional knowledge to pass four special tests on pedagogy, psychology, teaching methods, and teaching ability. The pedagogy, psychology, and teaching-methods tests are written exams, and the teaching candidate also must demonstrate multiple facets of teaching ability: subject-matter instruction, teaching process, classroom management, blackboard handwriting, and classroom questioning.

Having complied with the conditions previously described, an entrant can apply for a qualifiedteacher certificate. There are seven types of teaching certificates in China: kindergarten teacher; primary school teacher; junior-secondary teacher; senior-secondary teacher; secondary-vocational teacher; secondary-vocational school internship adviser, and highereducation school teacher. The certification qualifies a teacher for a teaching post at the level attained, or a lesser level. There is an exception: Those certified as vocational internship advisers can only work as internship advisers in specialized secondary schools, technical schools and vocational schools. The subject that can be taught is indicated clearly on the certificate. And certificates currently have no tenure limits, though there is a proposal under discussion to issue certificates with three different limits - temporary, time limited and lifelong.

Normal education students need only to pass the Mandarin test not the four-part professional-knowledge test because they are assumed to have obtained training as teaching professionals in their formal schooling. However, they are required to take part in a six- to eight-week teacher-preparation program.

Since 1999, regulations governing who can apply for a teaching certificate have been loosened as a way of enlarging the teaching force. Now, an applicant need not have graduated from a teacher-preparation institution, need not already have been a teacher, and need not have taken part in a teacher-preparation program. If the entrant can pass the four qualifying tests, he or she can obtain the teaching certificate. After acquiring a teaching certificate, the prospective teacher must find a school to employ him or her. There is no unified employment examination. Schools recruit new teachers on their own.

However, these legal requirements and standards are not strictly enforced in every corner of China. Not all who enter the occupation meet the legal education requirements; the scope and content of requirements to become a teacher vary widely among the different provinces. For example, in many rural schools in the western provinces, the formal schooling levels of many teachers lack four years of college and are below the seniorsecondary school level.

In his or her teaching career, a teacher also should take part in 
Table 3

Qualified Rate of Record of Formal Schooling of Elementary, Junior Secondary, Senior Secondary Teachers in China by Type of Subject Taught, Type of School, in PERCENTAGES, 2004

\begin{tabular}{|lccc|}
\hline & Elementary School & $\begin{array}{c}\text { Junior } \\
\text { Secondary School }\end{array}$ & $\begin{array}{c}\text { Senior } \\
\text { Secondary School }\end{array}$ \\
\hline Total & 98.31 & 93.79 & 79.60 \\
\hline Subject Taught Type & & & \\
Chinese & 98.42 & 95.91 & 84.20 \\
Math & 99.33 & 94.95 & 82.60 \\
Science & 98.01 & 94.99 & 81.97 \\
Social Science & 98.08 & 95.02 & 81.24 \\
\hline Poverty Enrollment & & & \\
Low (East) & 99.05 & 93.79 & 83.74 \\
Middle(Middle) & 98.78 & 95.12 & 73.73 \\
High (West) & 97.16 & 92.52 & 65.36 \\
\hline Community Type & & & 75.92 \\
Rural & 97.78 & 91.31 & 88.88 \\
Suburban & 99.13 & 94.94 & \\
Urban & 99.45 & 97.72 & \\
\hline
\end{tabular}

${ }^{4}$ Educational statistic yearbook of China 2004.

a. School includes all the public and non-state/private schools.

b. Low poverty refers to the East Region, which contains Beijing, Tianjin, Shanghai, Jiangsu, Zhejiang, Fujian, Guangdong and Shandong Provinces.

c. Middle poverty refers to the Middle Region, which contains Hebei, Shanxi, Liaoning, Jilin, Heilongjiang, Anhui, Jiangxi, Henan, Hubei, Hunan, Hainan Provinces.

d. High poverty refers to the West Region, which contains Guizhou, Guangxi, Inner Mongolia, Chongqing, Sichuan, Yunnan, Shaanxi, Tibet, Gansu, Qinghai, Ningxia, Xinjiang Provinces.

e. The three types of regions are determined by the central government of China.

continuing education and training. According to the Regulations for Continuing Education of Primary and Secondary School Teachers issued by China's Ministry of Education in 1999, training is in the following areas: political education and the ethics of teaching; specialtyknowledge updating and expansion; modern education theory and practice; study of teaching skills; and modern educational technologies. New teachers should take training of not less than 150 periods, and all teachers should take job training of not less than 240 periods every five years. One period equals about 45 minutes to one hour's learning time. Generally speaking, 150 periods of training means about one month of full-time off-job training or other equivalent endeavor. Teachers also are encouraged to pursue more schooling to improve their educational levels.
Teacher's schools and colleges, normal colleges and universities are the main providers of continuing education and training for teachers.

\section{Data and Measures}

The data presented in this chapter are based on two sources: China Education Yearbook and Educational Statistic Yearbook of China. The former is edited and issued by Ministry of Education, and the latter is by the ministry's Department of Development and Planning. Both of these two authoritative literatures are issued every year.

A system called "Qualified Rates of Record of Formal Schooling" is commonly used to measure the education level of teachers. As indicated above, a teacher qualified to teach in a primary school should have obtained secondary-teachers school education or above; a qualified junior-secondary teacher should have obtained a sub-degree or above; a qualified senior-secondary teacher should have obtained a bachelor's degree or above. The system has been in place for less than 10 years

\section{The Qualifications of the Teaching Force}

Table 3 shows the "qualified" rates of elementary, junior-secondary, seniorsecondary teachers in China by type of subject taught and by type of school. As a whole, the qualified rate at the elementary-school level is the highest, $98.31 \%$, while the seniorsecondary school rate is the lowest, $79.60 \%$. At the elementary-school level, science teachers have the highest qualified rate from the perspective of the four major subjects taught—native language; math; science including physics, chemistry and biology; and social science consisting of politics, history and geography. At the senior-secondary level, science teachers have the lowest. At the secondary level including both junior and senior, Chinese-language teachers have the highest rate. The qualified rate among social-science teachers is relatively lower at all school levels. From the perspective of poverty enrollment, the qualified rate in western China is the lowest while that of eastern regions is the highest at all school levels. The gap between the west and the middle of China is much wider than between the middle and the east. From the perspective of community type, the qualified rate in rural areas is the lowest while that rate in urban areas is the highest in all school levels. Meanwhile, the gap in the rates of qualified teachers between rural and urban at the senior-secondary school level is 
Table 4

PERCENTAGE of Record of Formal Schooling of ELEMENTARY School Teachers in China, by Type of School, by Type of Subject Taught, 20045

\begin{tabular}{|lccccc|}
\hline & Graduate & Undergraduate & Sub Degree & High School Diploma & Below High School Diploma \\
\hline Total & 0.02 & 4.58 & 44.16 & 49.55 & 1.69 \\
\hline Poverty Enrollment & & & & & \\
Low (East) & 0.02 & 5.88 & 49.76 & 43.39 & 0.95 \\
Middle(Middle) & 0.03 & 4.55 & 42.95 & 51.25 & 1.22 \\
High (West) & 0.02 & 3.22 & 38.21 & 55.71 & 2.84 \\
\hline Community Type & & & & & 2.22 \\
Rural & 0.01 & 2.14 & 38.00 & 57.63 & 0.87 \\
Suburban & 0.02 & 5.12 & 53.27 & 40.72 & 0.55 \\
Urban & 0.08 & 13.43 & 57.83 & 28.11 & 1.58 \\
\hline Subject Taught & & & & & 1.67 \\
Chinese & 0.02 & 4.40 & 45.49 & 48.51 & 1.99 \\
Math & 0.01 & 3.48 & 42.31 & 53.53 & 1.92 \\
Science & 0.03 & 4.03 & 37.40 & 56.55 & 46.30 \\
Social Science & 0.05 & 6.69 & 45.04 & & \\
\hline
\end{tabular}

somewhat surprising, at $27.23 \%$.

Tables 4, 5 and 6 show the percentage of the record of formal schooling of teachers as a whole, by type of school and by type of subject taught in elementary, juniorsecondary and senior-secondary school levels respectively. Nearly half of the elementary-school teachers are graduated from secondary teachers schools or senior-secondary schools, occupying $49.55 \%$. Secondary school teachers have higher records of formal schooling with $78.56 \%$ of senior-secondary school teachers holding bachelor's degrees and $64.66 \%$ of junior-secondary school teachers holding sub-degrees. The data reveal that in elementary schools, science teachers have the highest record of formal schooling with $0.03 \%$ holding graduate degrees and $4.03 \%$ with bachelor's. In secondary schools (including both junior and senior), Chinese-language teachers have the most schooling. Formal schooling for teachers is at a much higher level in the east, in
${ }^{5}$ Educational statistic yearbook of China 2004

urban areas, than in the west, in rural areas. Tables 7 and 8 discuss the types of teachers in elementary and secondary schools in China.

There are three types of teachers: full-time, part-time and substitute. Full-time teachers comprise the formal teaching force and most of them hold teachers' qualification certificates. Part-time teachers and substitute teachers are not part of the formal teaching force. Not all parttime teachers and substitute teachers hold teachers' qualification

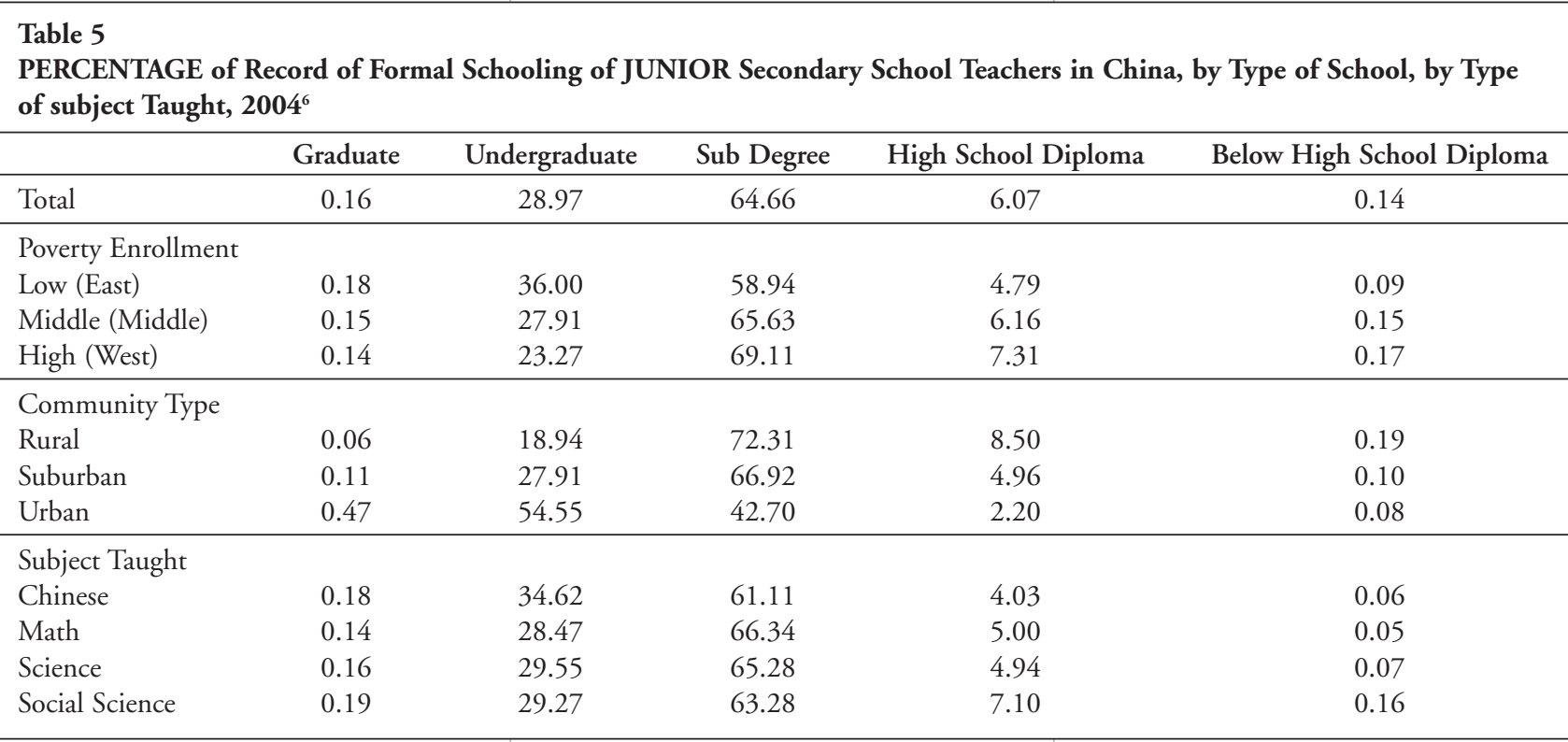




\begin{tabular}{|c|c|c|c|c|c|}
\hline \multicolumn{6}{|c|}{$\begin{array}{l}\text { PERCENTAGE of Record of Formal Schooling of Senior SECONDARY School Teachers in China, by Type of School, by Type } \\
\text { of subject Taught, } 2004^{7}\end{array}$} \\
\hline & Graduate & Undergraduate & Sub Degree & High School Diploma & Below High School Diploma \\
\hline Total & 1.04 & 78.56 & 20.00 & 0.39 & 0.01 \\
\hline \multicolumn{6}{|c|}{ Poverty Enrollment } \\
\hline Low (East) & 1.09 & 82.65 & 16.00 & 0.25 & 0.01 \\
\hline Middle(Middle) & 1.13 & 78.60 & 19.80 & 0.46 & 0.01 \\
\hline High (West) & 0.81 & 72.95 & 25.76 & 0.47 & 0.01 \\
\hline \multicolumn{6}{|l|}{ Community Type } \\
\hline Rural & 0.35 & 65.01 & 33.92 & 0.7 & 0.02 \\
\hline Suburban & 0.71 & 75.21 & 23.66 & 0.41 & 0.01 \\
\hline Urban & 1.68 & 87.20 & 10.84 & 0.27 & 0.01 \\
\hline \multicolumn{6}{|l|}{ Subject Taught } \\
\hline Chinese & 1.26 & 82.94 & 15.64 & 0.16 & 0.00 \\
\hline Math & 1.14 & 81.46 & 17.24 & 0.16 & 0.00 \\
\hline Science & 1.13 & 80.84 & 17.82 & 0.21 & 0.00 \\
\hline Social Science & 1.10 & 80.14 & 18.52 & 0.24 & 0.00 \\
\hline
\end{tabular}

Educational statistic yearbook of China 2004.

a. School includes all the public and non-state/private schools.

b. Senior School Graduate includes Secondary Teachers School Graduate and Senior Secondary School Graduate.

c. Below Senior School Graduate refers to Without Secondary Teachers School Certificate and Below Senior Secondary School Graduate.

d. Low poverty refers to the East Region, which contains Beijing, Tianjin, Shanghai, Jiangsu, zhejiang, Fujian, Guangdong and Shandong Provinces.

e. Middle poverty refers to the Middle Region, which contains Hebei, Shanxi, Liaoning, Jilin, Heilongiiang, Anhui, Jiangxi, Henan, Hubei, Hunan, Hainan Provinces.

f. High poverty refers to the West Region, which contains Guizhou, Guangxi, Inner Mongolia, Chongqing, Sichuan, Yunnan, Shaanxi, Tibet, Gansu, Qinghai, Ningxia,

Xinjiang Provinces.

g. The three types of regions are determined by the central government of China.

certificates. Most part-time teachers are either retired and holding the teachers' qualification certificate, or professionals without teachers' qualification certificates. Professionals typically are invited to teach a subject in which they have training.

Substitute teachers are found mainly in places with shortages of full-time teachers. They represent a temporary teaching force with some problems: first, most of them lack a qualified record of formal schooling; secondly, they work in poor areas and inferior teaching conditions; third, they earn lower wages.

Table 7 and 8 present the situation about the types of teachers in various types of school, in different communities, and in different poverty enrollment regions. As a whole, the percentage of substitute teachers in elementary schools is too high - $6.3 \%$ - and that in secondary schools is much lower but still at $2.5 \%$. At both elementary- and secondary-school levels, the percentage of full-time teachers is much higher at public schools than at private schools; the eastern region has more fulltime teachers than does the western region. Moreover, in most aspects, data on the middle and the east, of the suburban and the urban, are very close, but data on the west and of the rural show large lags to that of the middle and the east, and that of the suburban and the urban. In rural elementary schools, $8.05 \%$ are substitute teachers, while in western elementary schools, $11.21 \%$ are substitute teachers.

\begin{tabular}{|c|c|c|c|}
\hline & Substitute Teacher & Part-time Teacher & Full-time Teacher \\
\hline Total & 6.28 & 0.30 & 93.42 \\
\hline Public School & 6.29 & 0.25 & 93.46 \\
\hline Private School & 9.41 & 1.76 & 88.83 \\
\hline Others & 3.29 & 0.59 & 96.12 \\
\hline \multicolumn{4}{|l|}{ Community Type } \\
\hline Rural & 8.05 & 0.27 & 91.68 \\
\hline Suburban & 2.31 & 0.26 & 97.43 \\
\hline Urban & 3.49 & 0.46 & 96.05 \\
\hline \multicolumn{4}{|c|}{ Poverty Enrollment } \\
\hline Low (East) & 4.22 & 0.22 & 95.56 \\
\hline Middle (Middle) & 3.91 & 0.32 & 95.77 \\
\hline High (West) & 11.21 & 0.33 & 88.46 \\
\hline
\end{tabular}




\begin{tabular}{|c|c|c|c|}
\hline \multicolumn{4}{|c|}{$\begin{array}{l}\text { Table } 8 \\
\text { PERCENTAGE of Different Types of Teachers in SECONDARY Schools } \\
\text { in China, by Type of School, } 2004^{9}\end{array}$} \\
\hline & Substitute Teacher & Part-time Teacher & Full-time Teacher \\
\hline Total & 2.50 & 0.72 & 96.78 \\
\hline Public School & 2.20 & 0.40 & 97.40 \\
\hline Private School & 6.69 & 5.53 & 87.78 \\
\hline Others & 3.06 & 1.01 & 95.93 \\
\hline \multicolumn{4}{|l|}{ Community Type } \\
\hline Rural & 2.60 & 0.39 & 97.01 \\
\hline Suburban & 2.03 & 0.56 & 97.41 \\
\hline Urban & 3.06 & 1.45 & 95.49 \\
\hline \multicolumn{4}{|c|}{ Poverty Enrollment } \\
\hline Low (East) & 2.05 & 0.66 & 97.29 \\
\hline Middle (Middle) & 2.44 & 0.42 & 97.14 \\
\hline High (West) & 3.09 & 1.26 & 95.65 \\
\hline
\end{tabular}

${ }^{9}$ Educational statistic yearbook of China 2004.

a. Secondary schools include both senior and junior secondary schools.

b. Low poverty refers to the East Region, which contains Beijing, Tianjin, Shanghai, Jiangsu, zhejiang, Fujian, Guangdong and Shandong Provinces.

c. Middle poverty refers to the Middle Region, which contains Hebei, Shanxi, Liaoning, Jilin, Heilongjiang, Anhui, Jiangxi, Henan, Hubei, Hunan, Hainan Provinces.

d. High poverty refers to the West Region, which contains Guizhou, Guangxi, Inner Mongolia, Chongqing, Sichuan, Yunnan, Shaanxi, Tibet, Gansu, Qinghai, Ningxia, Xinjiang Provinces.

e. The 3 types of regions are determined by the central government of China.

f. Public School refers to those run by education department and communities.

g. Private School refers to those non-state, not primarily funded by local and national government.

h. Others refer to those run by non-education department.

\section{Out-of-Field Teaching}

In China, it is difficult to measure how many teachers are not qualified in the subject they teach. In China, the qualifications required to be an elementary school teacher are not as stringent as they are for teaching high school. In the secondary teachers schools preparing the teaching force for elementary schools, the curriculum for a prospective teacher in math is almost the same as for one in Chinese language.

Typically, when a secondary school (junior or senior) seeks to recruit new teachers, the school will identify which subjects have vacancies and how many positions need to be filled. For example, a school will declare that it needs three Chinese-language teachers, two mathematics teachers, four science teachers and one social-science teacher. To a certain extent, that protocol weeds out teachers who are not qualified to teach the relevant subject. It means that a secondary school will not hire someone majoring in mathematics as a Chinese-language teacher. Teachers in the social sciences are not so limited: Their major may have been history, politics, or geography; or sociology, philosophy, or some other arts major.

In poor rural areas, the situation is somewhat different. There are widespread shortages of qualified teachers, so incoming teachers somewhat frequently are assigned to teach subjects in which they have little background. In some poor, small schools, one teacher has to teach several subjects for one class, or even several grades. Almost all substitute teachers, who are not considered part of the formal teaching force and who work in the worst of conditions, are doing out-offield teaching. As mentioned above, this kind of problem is much more severe in the private schools than in the public ones, in the west than in the middle and the east, and in the rural than in the suburban and the urban.

\section{Implications and Conclusions}

The quality of teachers and teaching is undoubtedly a key factor in the education and schooling of a child. For many years, China's central and local governments have put much effort into teaching-force development. Despite great achievements, China still faces several severe problems needing remedies and reforms.

First, there is a large gap between the demand for and supply of elementary and secondary teachers. The shortage problem may arise from two sources: an insufficient supply of new teachers, and too many teachers quitting their jobs to pursue more attractive careers. In the former case, teacher-preparation education should be upgraded and expanded to educate and train more new teachers. Further, the teaching certificate system should be modified so that people who are interested in teaching and who are qualified but have not graduated from normal education institutions can enter the teaching field more easily. In addition, the treatment of teachers, including earnings, medical care and housing conditions, should be improved. Teaching conditions and work pressures also need attention. Further, teachers need more supports to help them see a promising prospect, to make their career meaningful, and to enjoy their teaching.

Secondly, China needs to raise its relatively low entry bar to the teaching occupation, especially at the primary and junior-secondary levels. At the same time, the rates of "qualified" teachers remain 
unsatisfyingly low. The source of this problem may be mainly a widespread shortage of teachers, mentioned above, but it also may be related to the insufficiency of continuing education and training for teachers.

Third, a very prominent feature revealed in an examination of the qualifications of the teaching force in China is the marked imbalance among various regions. There are large gaps between the rural and the urban, the west and the east. In all aspects, the situation of the rural and the western areas lags significantly. For example, applicants to be a teacher in an elementary school in Shanghai should hold at least a subdegree, while in some poor rural mountainous areas in the west, elementary schools have no choice but to employ teachers whose records of formal schooling fall short of a senior-secondary diploma. This situation may be considered a consequence of imbalanced economic development in China but such an excuse should not be used to justify an evasion of responsibilities. Surely the west and the rural need more financial support. Further, the education system itself needs reforms to adapt with due speed to special circumstances and to accelerate local development of teaching candidates. There have been some fruitful attempts in recent years such as the "Teaching Practice as Substitute Teacher" project in Southwestern Normal University (Zhang Shiya, et al., 2004) where normal-college education majors practice-teach their senior year and at the same time serve as substitute teachers in schools in poor areas. By adopting that approach, schools elsewhere in China could acquire sufficient additions to their qualified teaching forces to meet their needs, while the students serving as substitute teachers could greatly benefit from the one year of practice to enhance their qualifications. 


\section{References}

China education yearbook 2005.

Beijing: People Education Press.

China statistics yearbook 2004.

National Bureau of Statistics of

China.

Department of Development and Planning, Educational statistic yearbook of China 2004, Beijing: People Education Press.

Li Peilin \& Li Qiang Sun Liping. (2004). Social stratification in China's today, Beijing: Social Sciences Documentation Publishing House.

Project Team of China's Education and Human Resource Development (2002). Stride from a country of tremendous population to a country of profound human resources, Beijing: Higher Education Press.

Zhang Shiya \& Wu Xiaorong. (2004). Teaching practice as substitute teacher: Journals of rural education, In Ding Gang (Ed.), China's Education: Research \& Review, 7, Beijing: Educational Science Publishing House. 
28 


\title{
CHAPTER 3 \\ Qualifications of the Teaching Force in The Hong Kong Special Administrative Region, China
}

\author{
Kwok Chan Lai \\ The Hong Kong Institute of Education
}

\section{Introduction The Education System}

The academic structure in the Hong Kong Special Administrative Region encompasses six years of primary education (grades 1-6, ages 6-11), three years of junior secondary education (secondary grades 1-3, ages 12-14), and two years of senior secondary education (secondary grades 4-5, ages 15-16). After secondary grade 5 , students take a public exam-the Hong Kong Certificate of Education Examination. Those who meet the requisite standards may pursue a two-year sixth-form course (secondary grades 6-7, ages 17-18) leading to the Hong Kong Advanced Level Examination for admission to institutions of higher education.

The school system in Hong Kong is relatively uniform. Nearly all primary schools offer classes in grades $1-6$, while nearly all secondary schools run through grade 7 . Ninety percent of school facilities are operated by the government. There also are schools called "aided schools," which are run by voluntary bodies but are fully funded by the government. Both types of schools share a common salary scale for teachers and follow a centrally prescribed curriculum. In addition, there are a number of private schools, including "Direct Subsidy Scheme" schools, which receive financial assistance from the government but have the freedom to set their own school fees, teacher salary scales, school curriculum and student admission policies.

In both government and aided schools, the primary-school curriculum typically consists of Chinese language, English language, mathematics, general studies (a subject integrating social studies and science), visual arts, music, physical education, and information and communication technology (ICT). At the junior-secondary level, the education consists of Chinese, English, mathematics, integrated science, integrated humanities (or studies of individual social subjects such as geography, history and Chinese history), ICT, physical education, visual arts, and music. At the senior-secondary level, nearly all students study the core curriculum of Chinese, English and mathematics. However, the other subjects taken by students usually depend on their subject streaming or concentration, that is, whether they choose the science, arts, commerce or technical studies stream. For instance, science- stream students usually study physics, chemistry, biology or additional mathematics, while arts students study geography, history, economics, Chinese history or literature.

In the realm of higher education, the eight institutions funded by the Hong Kong government's University Grants Committee offer postgraduate, undergraduate and a small number of associate-degree programs. Undergraduate programs typically are three years in duration.

In terms of governance, the Education and Manpower Bureau of the government, headed by the Secretary for Education and Manpower, is responsible for formulating and reviewing education policies and overseeing the implementation of education programs. Prior to the year 2003, policy implementation at the school level had been under the remit of the Education Department, headed by the Director of Education. In 2003, to strengthen the links between the formulation and implementation of policies, the Education Department was dismantled and its work was subsumed under the Education and Manpower Bureau. The work of the bureau is supported by various consultative committees, including the Education Commission, the 
Advisory Committee on Teacher Education and Qualifications, and the Standing Committee on Language Education and Research.

\section{The Teacher Education System}

Much like many other places formerly under British rule, teacher preparation in Hong Kong until the mid-1990s was separated into "nongraduate" and "graduate" tracks using one of two models:

- Concurrent model: Governmentrun Colleges of Education offered two- and three-year full-time subdegree-level programs (known as Teachers' Certificate or Certificate in Education programs) to prepare "nongraduate" teachers for primary schools and the junior levels of secondary schools. The program content in those programs covered both professional and subject studies; and

- Consecutive model: Faculties of education of two comprehensive universities offered a one-year fulltime Postgraduate

Certificate/Diploma in Education program to prepare seniorsecondary teachers. This type of program also is known as the " $3+1$ " route because it focuses on one year of professional training for graduates who have completed a three-year bachelor's degree with an academic major. As such, this model is similar to a fifth year or a post-baccalaureate program in the United States.

This dual track of teacher education has gradually disappeared since the mid-1990s. First, with the creation of positions for degree holders in primary schools, primary teaching no longer is regarded as a career for nongraduates. Second, in 1994 the Colleges of Education were amalgamated to form the Hong Kong Institute of Education, which began to replace subdegree-level awards in both primary and secondary education with bachelor's degrees and postgraduate diplomas.

At present, teacher education is offered at three comprehensive universities, the Institute of Education, and the Open University of Hong Kong. Both concurrent and consecutive pathways of pre-service teacher education now serve to prepare primary and secondary teachers, a system similar to that in the United Kingdom. The major change has been in the concurrent pathway, where the former certificate-level programs have been upgraded to four-year undergraduate programs in education leading to Bachelor of Education (B.Ed.) or a B.A. or B.Sc. in education degrees, including a practice-teaching period of 14 to 16 weeks.

The quality of new entrants to the teaching profession has always been a matter of concern. The findings of a study by Lai et al. (2005a) on senior-secondary school students' perceptions of teaching relative to other careers suggested that while teaching in the Hong Kong society remains a well respected occupation, the teaching profession does not attract young people with high academic marks. In addition, the examination grades of new students admitted to teacher education programs in the comprehensive universities were generally lower than those admitted to other disciplines (University of Hong Kong, 2007).

\section{The Changing Policy Context}

A focus on education policy in Hong Kong in the 1970s and early 1980s culminated in the introduction of free and compulsory six-year primary education in 1971 and the expansion of compulsory education to secondary grade 3 (or age 15) in 1978. These developments resulted in a tremendous demand for primary and secondary school teachers, and many of those recruited to be teachers in fact lacked training. For a time, the Hong Kong government focused attention on the creation of more school facilities to open classrooms for nine years of compulsory education. Beginning in the late 1980s, the government shifted its attention to raising the quality of education.

In the early 1990s, the government decided to massively expand its higher education network. As a result, the number of students enrolled in degree programs rapidly increased, and the subdegree teacher education programs offered by the former Colleges of Education became less attractive. Subsequently, the government commissioned the Education Commission to review the teacher education system, with a particular focus on ways of enhancing the attractiveness of the teaching career in primary schools. The recommendations of Education Commission Report No. 5 (1992) were far-reaching, and included: - establishing positions for bachelor's degree holders in public-sector primary schools and upgrading $35 \%$ of teaching posts to graduate status within 15 years;

- encouraging nondegree teachers to enroll in add-on degree programs to upgrade their qualifications to degree level; and

? amalgamating the Colleges of Education to form an autonomous institution, the Hong Kong Institute of Education.

In the mid-1990s, in another directive aimed at ensuring the provision of good-quality schools, the 
government asked the Education Commission to begin another study on measures to improve school management and performance. EC Report No. 7 (1997) recommended that the professional education of principals and teachers needed to be strengthened to equip them with knowledge and skills to cope with the changes:

To provide quality school education, we need quality principals and teachers with a strong sense of mission, appropriate personal attributes, adequate academic and professional qualifications. They should be prepared to initiate and participate in the development of quality education. In return, they should be provided with suitable support and development opportunities. (p. 35)

After the establishment of the Special Administrative Region under Chinese sovereignty in 1997, the new Chief Executive and the regional government were zealous in their efforts to reform Hong Kong's education system to meet challenges related to globalization and creation of a knowledge-based economy essential to Hong Kong's social and economic development (Hong Kong, 1997). These efforts included measures to raise the preparation standards of the teaching profession, which we will discuss in detail in the next section. At the same time, the Education Commission began a comprehensive review of the education system with a view to drawing up a blueprint for reform for the 21st century (Hong Kong, 1997). Based on its recommendations, wide-ranging education reforms in academic structure, school curriculum and assessment have been launched in the past six years (Education Commission, 2000).

In the quest for quality education, the government increasingly has resorted to official, top-down reform measures heavily influenced by notions of managerialism, privatization and performance standards in education (Choi, 2005; Lai, 2005). The Education and Manpower Bureau (EMB) and its consulting committees have been actively involved in formulating policies and detailed guidelines to raise competency standards for both new and serving teachers. Further, the EMB has become more active in controlling teacher-education institutions through the University Grants Committee-for instance, by stipulating student-intake numbers for various subjects.

The purpose of this paper is to review the formulation and implementation of policies that have influenced teacher qualification requirements and standards in Hong Kong amid the profound changes in the political, economic and social contexts since the 1990s. In the concluding section, we will examine the government's paradoxical policies towards teacher quality: While the government is keen to improve professional standards to support education reform, in the recent past it has been unwilling to require new teachers to be professional trained. At the same time, it is preoccupied with measures to ensure that Englishlanguage teachers are both in good supply and "highly qualified." The paper will offer a critique of these issues, which may have implications for teacher-education policies elsewhere.

\section{Teacher Preparation Requirements and Standards}

Professional Training Requirements Any person who wishes to teach in a school in Hong Kong has to apply to the Education and Manpower Bureau (formerly the Education Department) for registration as a "registered" or a "permitted" teacher. To qualify for registration as a registered teacher, a person will have obtained "qualifiedteacher" status through completion of an approved teacher education program offered by a recognized institution. This program may be a subdegree-level Certificate in Education, a Bachelor's Degree in Education, or a Postgraduate Certificate/Diploma in Education. In this regard, a registered teacher is equivalent to full licensure in the United States. However, in Hong Kong, "qualified" teacher status does not specify the subject area that a teacher can teach. Furthermore, there is no need for graduates from teacher education institutions to fulfill any additional requirements, such as passing a test, to become a registered teacher.

On the other hand, a person holding the minimum academic qualifications but without a recognized teacher-training qualification may be employed by a school as a "permitted" teacher. $\mathrm{He} / \mathrm{she}$ will be eligible to be a registered teacher after acquiring qualified-teacher status through completion of in-service training.

The "permitted teacher" status in Hong Kong is similar to emergency certification or emergency permit in the United States in the sense that permitted teachers have not met the minimum requirements for full registration. However, there is no stipulation that permitted teachers must complete teacher training in a specified period to receive registered status. In other words, they will be allowed to stay in the teaching force indefinitely. Until the year 2004, the requirements were so lax that a 
permitted teacher was eligible for registration as a registered teacher through mere accumulation of teaching experience.

Nevertheless, a few measures have been put in place to encourage permitted teachers to undergo inservice training. For instance, a salary bar is imposed on them should they fail to complete their professional training within the first five years of service. Training also is necessary for promotion to senior teacher posts.

From the 1950 s to the 1970 s, untrained teachers or permitted teachers had been regarded as a convenient buffer to meet the tremendous expansion in mass education. In 1974, the percentages of untrained primary and secondary teachers, many of whom had only completed secondary schooling, were as high as $27.5 \%$ and $67.4 \%$ respectively. In the mid-1990s, with the stabilized demand for new teachers and the expansion of teacher training capacity, the corresponding percentages had significantly decreased to below 15\% and 25\% respectively.

Though the Education and

Manpower Bureau stipulates that schools should give priority to appointing teachers with teachertraining qualifications, this guideline has never been enforced. It was not until 1997 that Hong Kong's new chief executive announced the policy objective of requiring all new primary- and secondary-school teachers to be graduates and professionally trained in the "foreseeable future." This policy was warmly welcomed by the educational community. To achieve the "all graduate, all trained" objective, the chief executive announced in 1998 that subdegree primary and secondary teacher-education programs offered by the Institute of Education would be gradually replaced by degree or above programs (Hong Kong, 1998). However, no target year has hitherto been set to implement this policy. Without a firm policy commitment, untrained teachers have continued to join the teaching force. In 2005, nearly onequarter of the teachers newly joining the profession were untrained.

\section{Academic Qualifications Requirements}

The minimum qualification required to be registered or permitted teachers in primary and secondary schools used to be secondary-school graduation, i.e. attainment of the Certificate of Education

Examination. Only recently, in 2004, was the requirement raised to include possession of a post-secondary diploma equivalent to an associate degree in the United States.

However, in reality, the academic qualifications of teachers are much higher than the minimum requirements stipulated by legislation. At present, the majority of new and serving teachers in both primary and secondary schools possess a bachelor's degree or above. As mentioned in a previous section on the Teacher Education System, since 1998, all pre-service teachereducation programs at less than full bachelor's degree or sub-degree level have gradually been replaced by degree-level programs. In 2004, the last cohort of certificate-level students graduated, symbolizing the complete upgrading of all pre-service teacher education for primary and secondary teachers to degree level. In 2005, $82.5 \%$ of primary and $95.2 \%$ of secondary teachers newly joining the teaching force possessed a degree qualification.

Professional Development and New Standards Requirements for
Serving Teachers

In Hong Kong, once teachers have acquired qualified-teacher status, that status will remain valid throughout their teaching careers. In other words, there are no professional-development requirements for the purpose of relicensing, except for those teachers who wish to apply for promotion to senior posts.

However, in the past few years, the standards of the teaching profession have been the subject of increasing scrutiny by the government and the community. The government has issued numerous reports, policy papers and speeches urging principals and teachers to actively participate in professional development, which is seen as crucial to the success of the education reform. In particular, the government has taken an active role in setting policies to raise the academic and professional standards of language teachers.

In the past decade, the Hong Kong government and the business community have been increasingly concerned with the allegedly falling English standards of university and school graduates and keen to improve the quality of language teaching in schools. In the year 2000, the government decided to set up language proficiency requirements for over 15,000 new and serving teachers of English and Putonghua (Mandarin) in both primary and secondary schools. These teachers would have to satisfy the requirements in five areas: reading, writing, listening, speaking, and classroom language assessment. Specifically, any teacher who began teaching English or Putonghua from September 2004 would have to demonstrate, before taking up the responsibility, that she or he had already met the requirement. In 
addition, all serving teachers in these two subjects will have to meet the requirement before the end of the 2005-06 school year. Those who failed to attain the requirement would not be allowed to teach the respective language subjects.

The language-proficiency requirements represent the first direct and large-scale government intervention to establish mandatory professional standards for serving teachers, besides the requirement of obtaining qualified-teacher status. This had led to vehement protests by teacher unions that objected to the "re-licensing" of qualified teachers. Eventually, the government compromised by granting exemptions to teachers who already had a degree major in the relevant language subject; it also agreed to allow teachers to attain the requirements through in-service training as an alternative to open assessment.

Even before the proficiency requirement target date was set, the government began to stipulate that all English- and Chinese-language teachers also should be well grounded in subject knowledge and the pedagogy of their respective subjects. In 2003, a report by the Standing Committee on Language Education and Research (SCOLAR) stated that:

Effective language teachers need to be proficient in the language they teach, have a good grounding in subject knowledge, and be acquainted with the latest theories and practices in language teaching and learning. They synthesize and apply their knowledge and skills to motivate and help their students to improve language ability. (p. 19)

Following the recommendations of the committee, the government requested that all school principals, starting with the 2004-05 school year, recruit language teachers who had both a degree in the relevant language subject and teacher education qualifications with a major in that language subject. If the new recruit does not have a relevant degree major, he or she should complete a first degree or postgraduate-level program focusing on the subject knowledge of the particular language within five years. In addition, if the recruit does not have teacher training, he/she will have to complete a teacher-education program with a language major within three years.

At the same time, serving language teachers are encouraged to upgrade their qualifications and pursue continuing professional development. To help language teachers who do not have a degree majoring in the relevant language, the government provided incentive grants for postgraduate programs for teachers to upgrade subject knowledge. By January 2005, over 3,600 applications had been approved. Total funding of over HK $\$ 600$ million (US $\$ 77$ million) had been allocated.

For teachers of all subjects, another consultative committee, the Advisory Committee on Teacher Education and Qualifications, published a report in 2003 setting out a teacher competencies framework as well as a policy framework for the continuing professional development of serving teachers. It recommended that all teachers should engage in continuing professional development activities of not less than 150 hours in a threeyear cycle. The recommendations are not mandatory. However, amidst the falling birth rate and declining student enrollment in Hong Kong, teachers are increasingly concerned about job security. Many of them have decided to choose professional development programs that satisfy the qualification and standards requirements stipulated by the government, irrespective of their interests or their specific needs of professional development (Lai, 2005).

\section{Data and Measures}

Most of the data presented in this chapter are derived from the Statistics on Primary and Secondary School Teachers, 2004/05 (titled as Teacher Statistics from 2000 to 2003, and Teacher Survey prior to 2000) published by the Education and Manpower Bureau.

Prior to the 2002-03 school year, teacher statistics were collected yearly by the government through administering a survey questionnaire through schools to all 50,000 primary and secondary teachers, the employment data of which were verified by the school administration. Since 2002-03, schools and teachers have been asked to update their staff and personal profiles through a Webbased e-services system. The response rate has been very high as each school is held accountable for ensuring data is submitted by the school's teachers. The Education and Manpower Bureau also sends reminders to those schools that have not submitted their returns.

Teacher Statistics differentiates subject teachers into two types-those teaching a subject as their main field (or first major subject taught) and those teaching the subject as either their main field or a secondary/additional field (or as one of the subjects taught). By definition, the number of teachers in the latter category is larger than the former. For instance, in the year 2005, among newly arriving teachers in secondary schools, 82 taught Chinese 
history, but only 14 of them taught the subject as their main or first major subject.

Finally, since nearly all secondary schools in Hong Kong operate classes at both the junior- and seniorsecondary levels, it also is common for teachers to teach across both levels. In this regard, the Hong Kong teacher statistics do not contain a breakdown by these levels.

\section{The Qualifications of the Teaching Force}

In 2005, the number of permanent teachers in government, aided and private primary, secondary and special schools were $22,127,26,163$ and 1,380 respectively. Among them, $73.4 \%$ of primary- and $92.2 \%$ of secondary-school teachers held at least a bachelor's degree. In primary schools, the percentage of degreeholding teachers was the highest in government schools. The corresponding percentages were similar across all types of secondary schools (Table 1).

In primary schools, the subjects with the highest percentages of degree holders were English language (79\%) and ICT (78.2\%). In secondary schools, nearly all the teachers of senior secondary science subjects (i.e., biology, chemistry and physics) and economics were degree holders, followed by Englishlanguage teachers $(95.5 \%)$. It is notable that both primary and secondary schools prefer to deploy degree holders to teach English language, irrespective of their subject training.

In the past few years, there has been a steady increase in the number of teachers who possessed postgraduate qualifications: in 2005, $7.3 \%$ and $24.9 \%$ of primary and secondary school teachers,
Table 1

Number of Teachers in Hong Kong by Academic Qualifications/Training, 2005'

\begin{tabular}{|c|c|c|c|c|c|}
\hline Level/ Sector & $\begin{array}{c}\text { Less than } \\
\text { Bachelor's } \\
\text { Degree }\end{array}$ & $\begin{array}{c}\text { Bachelor's } \\
\text { Degree or } \\
\text { Above }\end{array}$ & Untrained & Trained & $\begin{array}{c}\text { Bachelor's } \\
\text { Degree or } \\
\text { above and } \\
\text { Trained }\end{array}$ \\
\hline \multicolumn{6}{|l|}{$\begin{array}{l}\text { Primary Schools } \\
(\mathrm{N}=22,127)\end{array}$} \\
\hline Government Schools & $\begin{array}{c}268 \\
(17.1 \%)\end{array}$ & $\begin{array}{c}1,302 \\
(82.9 \%)\end{array}$ & $\begin{array}{c}10 \\
(0.6 \%)\end{array}$ & $\begin{array}{c}1,560 \\
(99.4 \%)\end{array}$ & N/A \\
\hline Aided Schools & $\begin{array}{c}5,103 \\
(27.3 \%)\end{array}$ & $\begin{array}{l}13,608 \\
(72.7 \%)\end{array}$ & $\begin{array}{c}820 \\
(4.4 \%)\end{array}$ & $\begin{array}{l}17,891 \\
(95.6 \%)\end{array}$ & N/A \\
\hline Private Schools & $\begin{array}{c}510 \\
(27.6 \%)\end{array}$ & $\begin{array}{c}1336 \\
(72.4 \%)\end{array}$ & $\begin{array}{c}342 \\
(18.5 \%)\end{array}$ & $\begin{array}{c}1,504 \\
(81.5 \%)\end{array}$ & N/A \\
\hline Total & $\begin{array}{c}5,881 \\
(26.6 \%)\end{array}$ & $\begin{array}{c}16,246 \\
(73.4 \%)\end{array}$ & $\begin{array}{c}1,172 \\
(5.3 \%)\end{array}$ & $\begin{array}{c}20,955 \\
(94.7 \%)\end{array}$ & $\begin{array}{c}15,495 \\
(70.0 \%)\end{array}$ \\
\hline \multicolumn{6}{|l|}{$\begin{array}{l}\text { Secondary Schools } \\
(\mathrm{N}=26,163)\end{array}$} \\
\hline Government Schools & $\begin{array}{c}168 \\
(8.7 \%)\end{array}$ & $\begin{array}{c}1,757 \\
(91.3 \%)\end{array}$ & $\begin{array}{c}27 \\
(1.4 \%)\end{array}$ & $\begin{array}{c}1,898 \\
(98.6 \%)\end{array}$ & N/A \\
\hline Aided Schools & $\begin{array}{l}1,658 \\
(7.9 \%)\end{array}$ & $\begin{array}{l}19,449 \\
(92.1 \%)\end{array}$ & $\begin{array}{c}762 \\
(3.6 \%)\end{array}$ & $\begin{array}{c}20,345 \\
(96.4 \%)\end{array}$ & N/A \\
\hline Caput Schools & $\begin{array}{c}39 \\
(10.1 \%)\end{array}$ & $\begin{array}{c}346 \\
(89.9 \%)\end{array}$ & $\begin{array}{c}19 \\
(4.9 \%)\end{array}$ & $\begin{array}{c}366 \\
(95.1 \%)\end{array}$ & N/A \\
\hline Private Schools & $\begin{array}{c}179 \\
(6.5 \%)\end{array}$ & $\begin{array}{c}2,567 \\
(93.5 \%)\end{array}$ & $\begin{array}{c}516 \\
(18.8 \%)\end{array}$ & $\begin{array}{c}2,230 \\
(81.2 \%)\end{array}$ & N/A \\
\hline Total & $\begin{array}{l}2,044 \\
(7.8 \%)\end{array}$ & $\begin{array}{l}24,119 \\
(92.2 \%)\end{array}$ & $\begin{array}{l}1,324 \\
(5.1 \%)\end{array}$ & $\begin{array}{c}24,839 \\
(94.9 \%)\end{array}$ & $\begin{array}{l}23,001 \\
(87.9 \%)\end{array}$ \\
\hline
\end{tabular}

${ }^{1}$ Statistics on primary and secondary school teachers, 2005/06.

a. Caput schools are schools that receive Government assistance in the form of a per caput grant

b. Private schools include Direct Subsidy Schools respectively, held a masters' degree or higher.

In terms of professional qualifications, $94.7 \%$ and $94.9 \%$ of primary and secondary school teachers possessed teacher education qualifications. The percentage of trained teachers was highest in government schools (Table 1). In primary schools, the percentage of teachers without teacher training was the highest in the following subjects: English language (3.8\%), music $(2.9 \%)$ and general studies (3.2\%). In secondary schools, the corresponding subjects were ICT (5.8\%), music (6.7\%), mathematics (5.5\%), physics (4.4\%) and English (4.5\%).

Overall, the majority of serving teachers have completed a bachelor's degree level university education and also held professional qualifications.
Table 2

Number of Teachers by Academic and Teacher Training Qualifications, 2005²

\begin{tabular}{|lccccc|}
\hline \multirow{5}{*}{ Primary } & $\begin{array}{c}\text { Degree \& } \\
\text { Trained }\end{array}$ & $\begin{array}{c}\text { Non-degree } \\
\text { \& Trained }\end{array}$ & $\begin{array}{c}\text { Degree \& } \\
\text { Untrained }\end{array}$ & $\begin{array}{c}\text { Non-degree } \\
\text { \& Untrained }\end{array}$ & Total \\
& 15,495 & 5,460 & 751 & 421 & 22,127 \\
& $(70.0 \%)$ & $(24.7 \%)$ & $(3.4 \%)$ & $(1.9 \%)$ & $(100 \%)$ \\
& 23,001 & 1,838 & 1,118 & 206 & 26,163 \\
& $(87.9 \%)$ & $(7.0 \%)$ & $(4.3 \%)$ & $(0.8 \%)$ & $(100 \%)$ \\
\hline
\end{tabular}

${ }^{2}$ Statistics on primary and secondary school teachers, 2005/06. 
The corresponding percentages in primary and secondary schools were $70 \%$ and $87.9 \%$ respectively (Table 2).

However, in the absence of preservice training requirement, nearly one-quarter of the newly joined teachers are untrained. In 2005, 738 and 1,131 new teachers joined primary and secondary schools respectively, compared with 1,131 and 1,003 in 1997. Among them, the proportions without training were $24.8 \%$ and $23.9 \%$ respectively, compared with $37.2 \%$ and $70.6 \%$ in 1997. The data indicate that the reduction in the proportion of newly joined teachers without training had been faster at the secondary level than the primary level. Nevertheless, similar to past decades, these untrained teachers have continued to serve as a convenient buffer to meet teacher demand in Hong Kong.

\section{Out-of-field Teaching}

Caution has to be exercised when comparing the Hong Kong data on "out-of-field" teaching with those of other places. As mentioned previously, the Hong Kong data do not allow a breakdown between teachers of junior- and seniorsecondary levels. Since it is more common for teachers to teach out-offield at the junior-secondary levele.g. those with an academic major in Chinese language and history/geography often teach juniorsecondary Chinese history and English language respectively-the percentages of out-of-field teaching in secondary-school subjects in Hong Kong are likely to be higher than those places which only report outof-field teaching at the seniorsecondary level. Nevertheless, for a few subjects that mainly are offered at the senior-secondary level, such as individual fields of science (physics, chemistry, biology) and economics, the data are more comparable.

In addition, for the Hong Kong data, the criteria of matching the teachers' subject field with the teaching field are more stringent than those adopted in other places. For instance, a Hong Kong teacher with a subject major in mathematics or physics teaching ICT or one with a major in chemistry teaching biology will be classified as out-of-field. In this regard, the percentages of "outof-field" teaching in Hong Kong are likely to be higher than those reported in other places.

Nevertheless, the Hong Kong data include both majors and minors/electives as qualified for a teachers' subject field. In this regard, this definition of "subject-trained" is more lax than that adopted in other places in which only a teacher's subject major is counted.

Teaching outside one's subject field has long existed in Hong Kong, particularly in subjects in which there has been a short supply of qualified teachers. For instance, only $46 \%$ and $55.7 \%$ of the English language teachers in primary and secondary schools respectively were classified by the Education Department as "subject-trained" in 1996 (see Measure 1 below). It was only in the past few years that the government and the community have become concerned with this problem. Such an interest has largely arisen from two policy developments-first, the government's quest for "highly qualified" language teachers and second, the government's advocating of specialist teaching in three core primary school subjects-English language, Chinese language and mathematics. With the more stringent requirements, many language teachers who previously were considered as "qualified" are now categorized as "underqualified" or "out-of-field."

The state of out-of-field teaching also is affected by the quality of preparation in subject matter that primary- and secondary-school teachers receive. Similar to other places, secondary teachers in Hong Kong are prepared to teach one or two specialist subjects. However, the preparation of primary-school teachers is quite different from those countries that prepare teachers for generalist teaching in primary schools, such as the United States, United Kingdom, Australia, Japan and South Korea, and from those that practice specialist teaching, such as China. Until recently, primary teaching in Hong Kong is organized somewhere between the "generalist" and "specialist" approaches, and teachers teach on the average three to four subjects. Similarly, the former Colleges of Education and the Institute of Education prepared their graduates to teach three "general" subjects in primary schools, i.e. Chinese language, mathematics and general studies, plus a fourth elective subject chosen from the subjects of English, ICT, visual arts, music and physical education. Accordingly, the Teacher Statistics categorized nearly all these graduates, regardless of their teaching specialization, as subjecttrained in the three "general" subjects. Hence, the percentages of out-of-field teaching in these three subjects are very low, but much higher in the remaining elective subjects.

The Teacher Statistics in Hong Kong contains data on the number of teachers assigned to teach subjects that do not match their academic majors or minors in degree/subdegree studies and their subject majors in professional or pedagogical training. Hence, through different combinations of these qualifications, it is possible to derive four measures 
of out-of-field teaching in Hong Kong (Table 3):

1. Non-subject-trained: teachers without a relevant subject major or minor in their academic studies at subdegree level or above or teacher training;

2. No relevant degree: teachers without a relevant subject major or minor in their degree studies;

3. No relevant teacher training: teachers without relevant teacher training in the subject they teach; and

4. No relevant subject in degree and teacher training: teachers without a relevant subject major or minor in their degree studies and teacher training. This stringent measure is analogous to the definition of "highly qualified" teachers in the United States and to that adopted by the Standing Committee on Language Education and Research as a benchmark for "highly qualified" language teachers.

Measure 1 is the most lax measure of the adequacy of subject preparation because any teacher who has taken the relevant subject as a major or minor in his/her academic (at subdegree level or above) or teacher-training program is regarded as "subject-trained." In other words, using this measure, any teacher who had taken a subject as one of his or her three general subjects in a subdegree certificate program in the former Colleges of Education will be classified as "subject-trained." This explains why only $3.3 \%$ of the primary Chinese-language teachers were classified as "non-subjecttrained" in 2005. In contrast, when the more stringent Measure 4 is adopted, the great majority $(79.2 \%)$ of these teachers will be categorized as non-subject-trained.

In general, the percentages of teachers considered inadequately prepared in the subject taught are higher under Measure 2 (i.e., no relevant degree) than those under Measure 3 (i.e., no relevant teacher

Table 3

Distribution of Teachers by Subject Taught by Whether Teaching Out-of-field, $2005^{3}$

\begin{tabular}{|c|c|c|c|c|c|}
\hline Subject Taught & $\begin{array}{c}\text { Without a } \\
\text { relevant subject } \\
\text { major or minor at } \\
\text { sub-degree level } \\
\text { or above or } \\
\text { teacher training } \\
\text { (Measure 1) }\end{array}$ & $\begin{array}{c}\text { Without a } \\
\text { relevant subject } \\
\text { major or minor at } \\
\text { degree level or } \\
\text { above } \\
\text { (Measure 2) }\end{array}$ & $\begin{array}{l}\text { Without relevant } \\
\text { teacher training } \\
\text { (Measure 3) }\end{array}$ & $\begin{array}{l}\text { Without a } \\
\text { relevant subject } \\
\text { major or minor in } \\
\text { degree studies } \\
\text { and teacher } \\
\text { training } \\
\text { (Measure } 4)\end{array}$ & $\begin{array}{c}\text { Total number of } \\
\text { teachers }\end{array}$ \\
\hline \multicolumn{6}{|l|}{ Primary Schools } \\
\hline Chinese Language & $3.3 \%$ & $78.8 \%$ & $4.1 \%$ & $79.2 \%$ & 10,246 \\
\hline English Language & $29.1 \%$ & $74.5 \%$ & $35.6 \%$ & $78.5 \%$ & 7,953 \\
\hline Mathematics & $5.9 \%$ & $91.0 \%$ & $6.3 \%$ & $91.3 \%$ & 9,543 \\
\hline General Studies & $6.0 \%$ & $88.0 \%$ & $8.2 \%$ & $89.8 \%$ & 9,404 \\
\hline Visual Arts & $53.1 \%$ & $93.3 \%$ & $65.1 \%$ & $94.1 \%$ & 5,655 \\
\hline Music & $29.5 \%$ & $80.2 \%$ & $42.6 \%$ & $82.2 \%$ & 3,160 \\
\hline Physical Education & $5.1 \%$ & $84.9 \%$ & $22.2 \%$ & $85.7 \%$ & 3,281 \\
\hline \multicolumn{6}{|l|}{ Secondary Schools } \\
\hline Chinese Language & $10.3 \%$ & $30.4 \%$ & $15.1 \%$ & $35.5 \%$ & 5,407 \\
\hline English Language & $10.5 \%$ & $34.8 \%$ & $18.9 \%$ & $41.9 \%$ & 5,614 \\
\hline Mathematics & $22.6 \%$ & $46.9 \%$ & $29.3 \%$ & $52.9 \%$ & 4,906 \\
\hline \multicolumn{6}{|l|}{ Science, } \\
\hline Science \& Technology & $10.8 \%$ & $33.5 \%$ & $17.1 \%$ & $38.7 \%$ & 2,205 \\
\hline Physics & $11.9 \%$ & $22.1 \%$ & $22.3 \%$ & $31.5 \%$ & 1,197 \\
\hline ICT & $49.8 \%$ & $59.8 \%$ & $69.3 \%$ & $78.8 \%$ & 2,863 \\
\hline Chinese History & $40.3 \%$ & $59.3 \%$ & $53.7 \%$ & $71.5 \%$ & 2,471 \\
\hline Geography & $22.3 \%$ & $34.3 \%$ & $27.6 \%$ & $39.5 \%$ & 1,447 \\
\hline Visual Arts & $10.8 \%$ & $40.6 \%$ & $17.4 \%$ & $46.1 \%$ & 867 \\
\hline Music & $13.2 \%$ & $34.8 \%$ & $26.6 \%$ & $46.1 \%$ & 597 \\
\hline Physical Education & $4.4 \%$ & $42.1 \%$ & $7.7 \%$ & $43.9 \%$ & 1,278 \\
\hline
\end{tabular}

${ }^{3}$ Statistics on primary and secondary school teachers, 2005/06.

a. Measure 1: For primary school teachers, regardless of their specialization, graduates from the Hong Kong Institute of Education (formerly Colleges of Education) are all regarded as subject-trained in Chinese Language, Mathematics, and General Studies. For cultural subjects, those having completed relevant in-service certificate courses also are classified as subject-trained.

b. Measure 1: Trained Teachers are teachers holding a post-graduate certificate/diploma in education, a degree in education, a sub-degree teacher certificate, or those who have been granted qualified status through the Non-graduate Teacher Qualifications Assessment scheme or equivalent. 
training), particularly in the primary schools. For example, while $91 \%$ of primary mathematics teachers do not have a relevant degree, only $6.3 \%$ of them have not received teacher training in the subject. The high percentages of the former are hardly surprising, as until a decade ago, primary teaching was still largely a career for nongraduates. In addition, despite the fact that many primaryschool teachers had subsequently obtained a bachelor's degree through part-time studies, they often had completed a general degree in education studies, instead of a degree with an subject major or minor.

The data in Table 3 show that, in primary schools, the percentages of teachers without professional training (Measure 3) are the highest in visual arts (65.1\%) and music (42.6\%).

The situation has reflected the longstanding practice in primary schools to assign untrained teachers to teach the cultural subjects, which generally are regarded as less academically demanding. This assignment also is in part due to administrative reasons as many school heads prefer to relieve the heavy marking load of language teachers by allocating them a few periods of visual arts or music. In fact, the visual-arts lessons are nicknamed by school heads as "dumb" lessons as teachers do not have to lecture their students most of the time.

Under all the four measures, the highest percentages of out-of-field teaching in the secondary schools are in ICT, Chinese history, and to a lesser extent, mathematics. For instance, the percentages of teachers without a relevant degree in the respective subjects (Measure 2) are as high as $59.8 \%, 59.3 \%$ and $46.9 \%$. This largely reflects the prevailing work assignment at the juniorsecondary level, in which school heads often assign science teachers to teach ICT and mathematics, or Chinese language teachers to teach Chinese history. Similar to the primary schools, this practice often is an administrative measure to bring about an equitable workload among teachers. Nevertheless, as explained earlier, the levels of out-of-field in Hong Kong secondary schools are relatively high compared to those in other nations are partly due to the fact that the Hong Kong data include both junior- and senior-secondary levels, and the criteria of matching the subject field with the teaching field are more stringent by definition.

The government and the community, nevertheless, are most concerned with out-of-field teaching in the subject of English language, particularly in the primary schools. Even using the most lax measure (Measure 1), nearly 30\% (29.1\%) of the English-language teachers in primary schools have not received any training or education in the subject, compared with $10.5 \%$ in the secondary schools. Other measures indicate that $74.5 \%$ of the former do not have a relevant degree, compared with $34.8 \%$ in secondary schools (Measure 2), and 35.6\% of the former are without a relevant teacher qualification (Measure 3).

Using the most stringent definition (Measure 4), 78.5\% of the primary English-language teachers have not taken the subject in degree course and teacher training, compared with $41.9 \%$ in secondary schools. These relatively high percentages have reflected a prevalent shortage in the supply of highly qualified English-language teachers in Hong Kong, as school heads often have to assign teachers without any training or education in English to teach the subject.

\section{Retreat on Professional Training}

Despite the fact that the chief executive had announced in 1997 the policy objective of requiring all new teachers to be graduates and professionally trained in the "foreseeable future," the government has hitherto refrained from setting a target year to achieve this policy. There is plenty of evidence that the government has actually retreated from the "all graduate, all trained" policy. In 1997, the University Grants Committee was asked by the government to make recommendations on how to achieve the policy, but its report (UGC, 1998) was never released to the public. Apparently, at that time, the government was concerned about the additional resources required to increase the number of pre-service teacher education places in universities. However, with a gradual decline in school enrollment and hence a reduced demand for teachers, this reason was no longer convincing.

As teacher educators increased their pressure on the government to implement the policy, the latter began to openly question the desirability of requiring all teachers to be pre-service trained. Different reasons were given. One was the inadequate supply of trained teachers in subject areas such as English language. Most disturbing of all, the government asserted that the training requirement would deter highly qualified people from entering teaching (Cheng, 2002). The Secretary for Education and Manpower openly stated that "to capture the best talents, the teaching profession must not be a closed system" (SEM, 2003). Interestingly, the government also referred to the arguments against pre-service teacher education in the United States in the 
past few years. On a radio program, a senior government official waved a copy of the report Meeting the Highly Qualified Teacher's Challenge: The Secretary's Annual Report on Teacher Quality (U.S. Department of Education, 2002) as supporting evidence.

The government thinking on preservice teacher education has influenced its teacher education policies. Instead of ensuring an adequate supply of pre-service trained graduates, it has instructed teacher education institutions to shift the balance of initial teacher education provisions from the preservice to the in-service route. The latter route was considered more cost-effective.

What has gradually emerged from the debate was that the government has serious doubts about the academic standards of students in teacher education, and perceives that the quality of noneducation university graduates is better because they have higher academic attainments and better mastery of subject content. Interestingly, this perception also is shared by some secondary school principals who contend that any training requirement would reduce their choices of teachers.

In the absence of a firm policy commitment, untrained teachers have continued to join the teaching force. As mentioned previously, in 2005 , nearly $25 \%$ of the newly joined primary and secondary school teachers are still untrained. This absence of training requirements for people to obtain employment as teachers in Hong Kong has been considered as a condition that maintains teaching as a low-status occupation and having a low level of professionalization (Morris, 2004). The retreat of the government from the "all graduate, all trained" policy only serves to perpetuate this situation.

\section{One Quest for High Quality}

While the government does not believe that new teachers have to be professionally trained, it paradoxically wants to ensure that language teachers are "highly qualified." As reported earlier, it has put in place the mandatory language proficiency requirement for Englishlanguage and Putonghua teachers, and supported the standing committee's policy requiring Chinese- and English-language teachers to have taken the relevant subject in degree- and teachertraining programs. These requirements are stringent by world standards and have a number of implications.

First, the new requirements mean that most language teachers who were previously regarded as "subjecttrained" (Measure 1) are no longer qualified. The impact is most serious for primary-school teachers because of the high proportion of nondegree teachers, and the generalist nature of their degree and teacher training.

Second, these policies have inadvertently raised the expectations of parents and the community of the standards of language teachers, and they have become more critical of the prevalent practice of out-of-field teaching in English language in schools. However, as serving teachers will not be able to attain the required qualifications within a short time span, the media and the community have been increasingly impatient and many parents have lost confidence in the quality of language teachers. Several times in a year, the media published the percentages of language teachers who have not met the language proficiency requirements or are teaching out-offield, with headlines like "Half of the teachers failed the language exams" or "Over $80 \%$ of English teachers not meeting the SCOLAR requirements." This usually led to further public outcries about the alleged poor quality of language teachers in Hong Kong. The repercussion is that the image of the whole teaching force has been adversely affected.

With the portrayed negative image and an employment market already affected by a decline in student population, the attractiveness of the teaching career to prospective graduates has sharply declined in the past few years. For instance, studies by Lai et al. (2005a; 2005b) indicated that the percentage of Secondary 7 (year 13) students interested in teaching as a career had declined from $50.8 \%$ in 2002 to $34.2 \%$ in 2005 . In addition, recent data released by the tertiary institutions indicated that the admissions scores of secondaryschool students admitted to most undergraduate programs in Englishlanguage education had dropped as well. In short, instead of attracting more highly qualified entrants to language teaching, the government policies of setting stringent standards and criticizing serving teachers probably have quite the opposite effect.

There also is evidence that the government's preoccupation with the quest for highly qualified teachers in the language subjects had led to the marginalization of other school subjects, such as visual arts, music and general studies. First, many serving teachers and student teachers, being concerned about their employment prospects, prefer to study language subjects in their professional development or preservice teacher-education programs 
respectively, irrespective of whether such training really suits their own needs or interest. Second, in order to guarantee an adequate supply of qualified English teachers, the government has asked teachereducation institutions to shift a large number of teacher-education places from other subjects to English. As a result, it may result in an inadequate supply of qualified teachers in the non-English subjects. Third, the Institute of Education, in order to prepare its students for specialist teaching in the languages in primary schools, has reduced the curriculum time devoted to other subjects. In the future, it is likely that graduates in primary teacher education may only be qualified to teach one subject, despite that they may be assigned by school heads to teach other subjects in primary schools. Paradoxically, the government policy to quest for highly qualified teachers in one subject will lead to the increase the proportion of out-of-field teaching in other subjects. 


\section{References}

Cheng, Y. C. (2002, November 9) Teacher status revamp method seen as realistic. South China Morning Post, Education Post.

Choi, P. K. (2005). A critical evaluation of education reforms in Hong Kong: Counting our losses to economic globalization. International Studies in Sociology of Education, 15(3), 237-256.

Education Commission. (1992). Education Commission Report No. 5: The teaching profession. Hong Kong: Government Printer.

Education Commission. (1997). Education Commission Report No. 7: Quality school education. Hong Kong: Government Printer.

Education Commission. (2000). Learning for life, learning through life: Reform proposals for the education system in Hong Kong. Hong Kong: Government Printer.

Education and Manpower Bureau. (2006). Statistics on primary and secondary school teachers, 2005/06. Hong Kong: Government Printer.

Hong Kong. Chief Executive. (1997). Speech by the Chief Executive, the Honorable Mr. Tung Chee Hwa, at the ceremony to celebrate the establishment of the Hong Kong Special Administrative Region. Hong Kong: Government Printer.

Hong Kong. Chief Executive. (1998). The 1998 policy Address: From adversity to opportunity. Hong Kong: Government Printer.
Lai, K. C. (2005). Bureaucratic control and the professionalization of Hong Kong primary teachers. New Horizons in Education, 51, 1-8.

Lai, K.C., Chan K.W., Ko, K.W., \& So, K.S. (2005a). Teaching as a career: A perspective from Hong Kong senior secondary students. Journal of Education for Teaching, 31(3), 153-168.

Lai, K.C., Chan, K.W., Ko, K.W., \& So, K.S. (2005b). Teaching as a career in Hong Kong: Understanding seven secondary students' perceptions. Unpublished document.

Morris, P. (2004). Teaching in Hong Kong: Professionalization, accountability and the state. Research papers in education, 19(1), 105-121.

Standing Committee on Language Education and Research. (2003). Action plan to raise language standards in Hong Kong: Final review report. Hong Kong: Government printer.

U.S. Department of Education. (2002). Meeting the highly qualified teacher challenge: The Secretary's annual report on teacher quality. Washington, DC: U.S. Government Printing Office.

University Grants Committee. (1998). Review of teacher education. Unpublished document. Hong Kong: University Grants Committee.

University of Hong Kong. (2006). JUPAS admission grades. Retrieved February 13, 2007, from http://www.hku.hk/admission/jupasgrades.htm 


\title{
CHAPTER 4 The Qualifications of the Teaching Force In Japan
}

\author{
Hidenori Fujita \\ International Christian University \\ In collaboration with Walter Putnam Dawson \\ International Christian University
}

\section{Introduction}

It has been said repeatedly that teacher quality is crucial for successful schooling. But current neo-liberal and market-oriented education reforms seem to have had the substantive effect, generally, of undermining the bases for teacher collaboration, discouraging teachers from taking initiative, and damaging their sense of efficacy and confidence, thereby deteriorating the quality of teaching and schooling. Unfortunately, this outcome seems to be the case in Japan.

From the 1970s, Japanese education began to attract attention as a successful example among many developed countries including the United States. It is ironical, then, that beginning in the 1980s, the Japanese government launched radical education reform. This reform still continues, being further intensified and attacking both public schools and their teachers. It is the time to re-examine seriously the necessity, appropriateness and effectiveness of current reforms, to determine whether they make schooling, teaching and learning better-or worse.

Stevenson and Stigler (1992) conducted cross-cultural research on teaching and learning, and students' mathematics and reading achievements, in American, Chinese, and Japanese elementary schools from the mid-1970s to the 1980s. They found that the academic achievement of Asian elementary school children was higher than that of their American counterparts. It is safe to say that teacher training and culture of teaching must have played a significant role in affecting these scores and outcomes. Indeed, the researchers identified two important characteristics of teaching in Japan. First, they stated that teacher training in Japan takes place largely as on-thejob training. Second, they noted that teachers' presence in a single staff room contributed to a collaborative culture for teaching facilitated by discussion of teaching practices with peers. Current reforms, however, have been undermining the foundations of this practical culture. Keeping the above in mind, this paper investigates some major characteristics of teacher training and the culture of teaching in Japan, and then, makes a brief explanation of and comments on current reforms in relation to those characteristics.

The Japanese education system as a whole has been characterized as a single-track 6-3-3-4 system with compulsory and neighborhood schooling at elementary and lower secondary levels. The system is founded on the value of meritocracy in that entrance exams determine admissions to high schools and universities. However, there also are many nonselective universities and special training colleges with open admissions policies. The Ministry of Education, Culture, Sports, Science and Technology (hereafter, the Ministry of Education) controls the education system centrally by deciding the curriculum and educational standards.

Japanese elementary and secondary education is characterized by a holistic approach that puts the full development of the child as its main goal. To this end, schools have a wide variety of rituals, events, and extracurricular activities. At both elementary and secondary levels, teaching and learning are homeroom-based in that students remain with the same teacher for most subjects in elementary school. In secondary school, students remain in the same homeroom where subject teachers instruct them in the different courses in the curriculum. 
Teachers at all levels of public education in Japan have maintained a strong sense of professionalism, which makes them dedicated career educators. However, in recent years educators have been confronted with a number of societal problems, which challenge them in their many roles (Fujita, $1991 \&$ 1997).

Globalization, the information technology revolution, and an increasingly more diverse and multicultural society all reflect changes in Japanese society with implications for educational practitioners. The knowledge base, incentives, and status for schooling have all changed. There are global standards for knowledge, technology, and qualifications. These developments raise important questions as to what knowledge should be taught and what skills developed.

Beyond questions of cognitive abilities, schools in Japan are called upon to solve social ills that may be the result of educational pathologies or social pathologies. Such problems include a breakdown in school authority structures, social maladjustment, and juvenile crime. Can schools be expected to bear the brunt of the responsibility to rid society of such overarching problems? They often are called upon to do just that (Fujita, 1997).

The current climate in the education sector in Japan is one of "reformism." A host of ideologies contend for the lead in educational policy dialogue. Among them are neoliberalism, neoconservatism, consumerism, privatization, marketization, and as well as a host of buzzwords such as "accountability" and "efficiency" (Fujita, 1997, 1998, 2000a, 2000b, \& 2005).

Major reform trends have included the reorganization of both the school system (the 6-3-3-4 system) and classroom-level practices toward values of "technicism," "testism," market competition, as well as individualism. There also are increased calls for decentralization, deregulation, and devolution of school management, curriculum design and policy-making power. Teachers are subjected to a culture of evaluation, inspection, and auditing. Most of these efforts serve to undermine proven practices in Japanese education and consist of misguided tinkering to the detriment of all Japanese stakeholders in education. Nevertheless, there are a number of aspects of Japanese education that remain strong, with teacher training being one of them despite the oncoming wave of "reformism" (Fujita, 1997, 2000a, \& 2005).

\section{Teacher Preparation Requirements and Standards}

In Japan there is the national curriculum (course of study), which has been revised about every 10 years and upon which entrance exams for senior high schools and universities should be based. Maximum classroom size is prescribed by the Ministry of Education, and funding for the salaries of public school teachers is provided by the central and prefectural governments ${ }^{1}$.

Public school teachers are hired by the prefectural board of education and rotated among schools in the prefecture usually every seven or eight years. Before employment these individuals matriculate from various teacher training programs at colleges and universities, and after employment, take a wide range of inservice training programs provided by the Ministry of Education, local boards of education and numerous voluntary study associations of teachers. There are three levels of teacher's certificates (Table 1). The highest is the "advanced level," which is conferred with a degree of master's or higher. The next is the first level certificate for an individual with a bachelor's degree, and the lowest certificate is the second level certificate, which is a temporary certificate valid for 15 years, for those with junior college degrees. In addition to the three levels of certification, there are three types of certificates. The general certificate is a non-subject-specific certificate for elementary school teachers. There is a "special subject certificate" for elementary school teachers in fields such as music, art, and home economics. Finally, the "subject-based certificate" is required for all secondary school teachers. The variety of teacher's certificates available can be seen in Table 1, produced by the Ministry of Education.

There are certain requirements for obtaining the different certificates delineated by the Ministry of Education. An applicant must graduate from a university with a teacher training program accredited by the Ministry of Education.

Furthermore, he or she must acquire all the prescribed credits for both subject courses and pedagogical and guidance courses ${ }^{3}$, and must participate in a three-week teaching practicum for all levels of teacher's certificates and a one-week nursing-

\footnotetext{
${ }^{1} \mathrm{~A}$ "prefecture" is a local administrative unit within which cities, towns and villages are encompassed. It is the equivalent of a state in the United States. There are 47 prefectures in Japan.

${ }^{3}$ Prescribed credits for the 1 st class certificate are as follows: For elementary school teachers, 8 credits of subject courses, 41 credits of pedagogical and guidance courses and 10 credits of either in addition to those for the BA degree; for junior high school teachers, 20 subject credits, 31 pedagogical and guidance credits and 8 credits of either; for senior high school teachers 20 subject credits, 23 pedagogical and guidance credits and 16 credits of either. In addition to these, 8 course credits on the Japanese Constitution, physical education, foreign-language communication, and media literacy are required for all three education levels.
} 
Table 1

Types of Teacher's Certificates in Japan. ${ }^{2}$

\begin{tabular}{|c|c|c|c|}
\hline Classification & $\begin{array}{l}\text { Completion of a } \\
\text { Master's course }\end{array}$ & $\begin{array}{c}\text { Completion of an } \\
\text { undergraduate course }\end{array}$ & $\begin{array}{l}\text { Completion of a } \\
\text { junior college course }\end{array}$ \\
\hline Elementary school teacher & \multirow{5}{*}{ Advanced certificate } & \multirow{5}{*}{1 st class certificate } & \multirow{2}{*}{ 2nd class certificate } \\
\hline Lower secondary school teacher & & & \\
\hline Upper secondary school teacher & & & \\
\hline Kindergarten teacher & & & \multirow{2}{*}{ 2nd class certificate } \\
\hline Nurse teacher & & & \\
\hline $\begin{array}{l}\text { Special school teachers } \\
\text { (for the blind, the deaf, } \\
\text { and the other disabled) }\end{array}$ & $\begin{array}{l}\text { Advanced certificate } \\
\text { (plus general certificate for } \\
\text { kindergarten, elementary, } \\
\text { lower and secondary } \\
\text { school teacher) }\end{array}$ & $\begin{array}{c}\text { 1st class certificate } \\
\text { (plus general certificate for } \\
\text { kindergarten, elementary, } \\
\text { lower and secondary } \\
\text { school teacher) }\end{array}$ & $\begin{array}{l}\text { 2nd class certificate } \\
\text { (plus general certificate for } \\
\text { kindergarten, elementary, } \\
\text { lower and secondary } \\
\text { school teacher) }\end{array}$ \\
\hline
\end{tabular}

Note: 1. Different lower and upper secondary school teacher certificates are available depending on the subject to be taught. The certificate for nurse teachers is the same regardless of special school type.

2. In addition to the general certificate, there are also special certificates and temporary certificates.

care internship for elementary and junior high school teacher's certificates. Upon completion of these requirements, the prefectural board of education will issue a teacher's certificate. However, the acquisition of a teacher's certificate does not guarantee employment.

Due to a decline in the schoolage population in Japan in recent years, the job opportunities for prospective teachers are limited and only about 30 to $40 \%$ of graduates of teacher training colleges are able to secure employment in public schools. In the next 10 years, however, job opportunities will expand dramatically due to the mandatory retirement of a large number of teachers.

A prospective teacher must pass a battery of tests as decided by the prefectural board of education or "ordinance-designated" city board of education ${ }^{4}$. These tests may include written tests, interviews, proficiency tests, and an essay test. The written examination includes a number of sections covering pedagogical theory and methods, educational psychology, student guidance and counseling, subject knowledge, education laws and regulations, educational administration, school management, and general school culture. The personal interview includes a requirement that the applicant conduct a demonstration lesson. Given the high level of competition for teaching jobs in Japan, there even are private cram schools, which prepare students for these examinations. The names of successful applicants are entered in the register of eligible teachers for each prefecture or district. Subsequently, boards of education assign these teachers to schools based on the staffing needs of the school. Upon employment, the first-year
${ }^{2}$ Japanese Ministry of Education homepage.

teacher is subjected to a one-year probationary period. Training does not end with the end of this probationary period, however.

One major characteristic of teacher training in Japan is the frequency and variety of in-service teacher training programs. This variety is reflected in the detail found in Table 2, which summarizes the teacher training scheme in Japan, as defined by the Ministry of Education. Another major reason for quality teaching in Japan can be attributed to this scheme of teacher training, which is closely linked with teachers' collaborative culture and with research-based instructional strategies.

As depicted here, teacher training in Japan is multi-dimensional, continuous, and systematic. There

${ }^{4}$ An "ordinance-designated city (ODC)" is a city with a population over 500,000 persons which has authority over educational administration like that of a prefecture. There are 15 ODCs. 
Table 2

Types of Teacher Training Programs in Japan. ${ }^{5}$

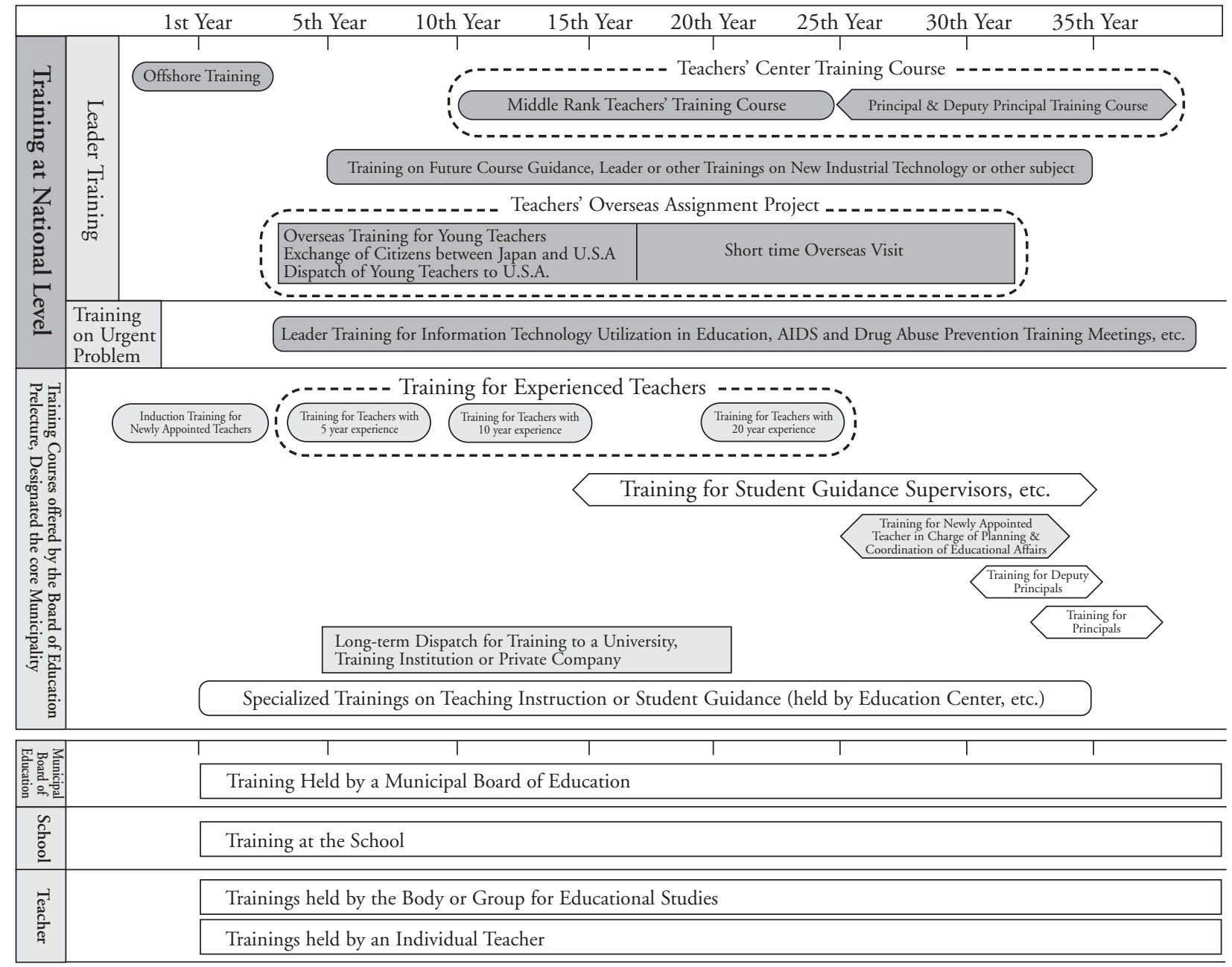

Training on Planning \& Coordination of Educational Affairs depending upon the experience

Trainings on Specialized Knowledge or Technology

Trainings depending on Others

Trainings held by the Government (Teacher Training Center)

Trainings Subsidized by the Government

Others the function

are five levels of teacher training: (1) the national level; (2) the prefectural board of education level; (3) the municipal board of education level; (4) the school level; and (5) the level consisting of voluntary educational associations, groups, and including individual teachers' self-training.

Training at the national level is largely classified into two categories, regular teacher training, and ad-hoc training that seeks to address specific issues such as information technology or AIDS education. Participants in these programs are expected to make presentations in their schools and communities on what they have learned.
${ }_{5}^{5}$ Japanese Ministry of Education homepage.

At the level of prefectures and large cities with populations over 200,000 persons, the boards of education are responsible for offering a series of training courses every year. These include (1) induction training for newly appointed teachers; (2) training for all teachers with five, 10 , or 20 years of experience; (3) training 
for curriculum coordinators, student guidance coordinators, viceprincipals, and principals; (4) longterm (one- or two-year) training programs in universities, research centers, or private companies for about 10 teachers selected from each prefecture and large city. There also are leader-training seminars for head teachers, principals, and viceprincipals. These programs are all compulsory but there also are programs created ad hoc by the local board of education or the education training center for which teachers either are selected or may volunteer.

Among these training programs, induction training and the training program for teachers with 10 years' experience are mandatory. The induction training program is a oneyear program that consists of two parts. The first part is a 60-day oncampus training period during which the trainee teaches two days a week. The second part is an off-campus training component during which the trainee teaches for one day a week. This off-campus training period includes a five-day teacher training retreat. Under the guidance of a mentor teacher each newly appointed teacher learns the various roles of the teaching profession. Offcampus training consists of a series of lectures, seminars, and workshops provided at the teacher training center in the prefecture or city, including school visits and other social activities.

The training program for teachers with 10 years of service includes 20 days of both on-campus and off-campus training periods. During the on-campus training period the teacher conducts a series of demonstration lessons, studies on teaching materials, a self-evaluation of his or her job performance, and discussions with the principal, viceprincipal, and other experienced teachers. The off-campus component takes place at the teacher training center and includes lectures, seminars, and workshops.

Teacher training at the level of municipal boards of education varies among the different municipalities depending on the educational issues that the municipalities have judged to warrant being the focus of training sessions. Teachers also take part in a variety of voluntary education study seminars, symposiums, and workshops organized by voluntary associations created by teachers.

There also are teacher training opportunities at the school level. Schools hold lesson-study seminars from time to time, which are open either to all teachers of the school or to teachers from other schools with a university professor and/or staff members of the local board of education invited as guest commentators. In the case where the school is designated and supported financially as a research and development school (R\&D school) by the local board of education or the Ministry of Education, it takes the form of an all-day workshop, often attended by hundreds of teachers. A typical program is composed of lesson demonstrations in all classes in the morning followed in the afternoon by theme-based discussions among the participants divided into several groups, and/or a lecture by a guest speaker such as a university professor, a superintendent of the local board of education, or some other distinguished person.

Teachers also take their own initiative to improve their pedagogical skills. There are a number of seminars and study groups that are voluntarily established and joined by teachers. They are created based on the following criteria: subject, region, teachers' union, university affiliation, and connections with other academic and educational associations. It is evident from the sheer number of types of training programs and organizations that teachers are provided with a wealth of mandatory and voluntary forums that they can participate in for the betterment of their pedagogical and administrative skills.

A number of issues have arisen related to the quality of teaching and teacher training in Japan. Subject knowledge and teaching skill are typical examples of targets for reform. Other areas for improvement include teachers' interpersonal relationship with their students, guidance and counseling, classroom management, as well as teachers' decline in confidence, dedication and morality. In relation to these themes, a number of reform initiatives have been implemented.

Some of the reforms have related to recruiting new teachers and providing training for lowperforming teachers. In order to add diversity to the teaching ranks, some districts have introduced a special teacher's certificate for those with experience in business or social work but lacking a formal teacher's certificate. For teachers who are underqualified, special training programs have been implemented and in some extreme cases teachers who have not proven their competence have been dismissed. A volunteer program also has been created so that some individuals can act as teaching assistants or help with extracurricular activities. More parttime teachers have been hired to reduce class sizes and help learners who require supplemental instruction. One very significant reform has been the introduction of a performance-based teacher evaluation system in Tokyo. Reforms such as this one, which was proposed and 
advocated by the Central Council of Education and business leaders, tend to start in Tokyo and then spread to other prefectures throughout Japan. Although numerous, these reforms are by no means the only reforms to be proposed. There are a number of reforms that are still under discussion and these are enumerated below.

One reform proposal would make teacher's certificates comprehensive and flexible. There is a plan to establish new graduate schools for teacher educator graduate programs. There also is a call to intensify certificate requirements by adding criteria to evaluate practical skills related to teaching. A further regulatory proposal would institute a renewal system whereby teachers would be required to renew their teacher's certificates after a designated number of years.

The reform initiatives and proposals address virtually every aspect of teacher training and certification. Before examining their value it is necessary to present some data to provide an overview of the state of teacher qualifications, job conditions, and attitudes.

\section{Data and Measures}

As discussed in a number of other chapters in this volume, teacher credentials are a basic indicator of the quality of teaching. The assumption is that higher credentials and credentials in the appropriate field indicate that a teacher should be an effective mode for the transmission of knowledge to his or her students. After examining statistics, it is necessary to read the statistical indicators reflecting teachers' job conditions and job satisfaction, as these are inevitably crucial for teacher retention.

\section{The Qualifications of the Teaching Force}

In Japan, as in other developed countries, there are a number of life paths that lead individuals to the teaching profession. Educational backgrounds can vary quite significantly for teachers holding virtually the same job status.

Table 3 presents the percentage of teachers with different credentials at the different levels of education. In this table, "normal college and university" stands for teacher training institutions at the higher education level, while "general college and university" stands for liberal arts colleges, technical colleges, and universities with several faculties ${ }^{6}$. "National schools" are those attached to national colleges and universities (national university corporations), while public and private schools are equivalent to those in the United States.

This table makes it evident that there is an overall tendency for upper secondary teachers to be graduates of general colleges and universities. In contrast, normal colleges and universities tend to send their graduates to public and national schools while private schools draw the

Table 3

Highest Degrees Held by All Fulltime Teachers at Different Levels of Education in Japan in PERCENTAGES, 20047

\begin{tabular}{|c|c|c|c|c|c|c|c|c|c|}
\hline & \multicolumn{4}{|c|}{ Normal College and University } & \multicolumn{4}{|c|}{ General College and University } & \\
\hline & Subtotal & MA or higher & $\begin{array}{c}\text { BA } \\
\text { Degree }\end{array}$ & $\begin{array}{c}\text { JC } \\
\text { Degree }\end{array}$ & Subtotal & MA or higher & $\begin{array}{c}\text { BA } \\
\text { Degree }\end{array}$ & $\begin{array}{c}\text { JC } \\
\text { Degree }\end{array}$ & \\
\hline Public Schools & & & & & & & & & \\
\hline Primary & 59.8 & 2.1 & 56.6 & 1.2 & 40.2 & 0.4 & 26.5 & 12.7 & 409,665 \\
\hline Lower Secondary & 40.3 & 2.5 & 37.5 & 0.3 & 59.7 & 1.1 & 51.9 & 6.3 & 235,317 \\
\hline Upper Secondary & 19.1 & 2.3 & 16.5 & 0.3 & 80.9 & 8.1 & 70.9 & 1.2 & 194,925 \\
\hline $\begin{array}{l}\text { Six-year Secondary } \\
\text { Private Schools }\end{array}$ & 37.9 & 6.1 & 31.8 & - & 62.1 & 4.5 & 54.5 & 3.0 & 136 \\
\hline Primary & 39.7 & 4.1 & 35.4 & 0.2 & 60.3 & 4.0 & 48.1 & 7.7 & 3,480 \\
\hline Lower Secondary & 16.1 & 3.1 & 13.0 & 0.1 & 83.9 & 15.8 & 65.8 & 2.0 & 12,837 \\
\hline Upper Secondary & 12.7 & 1.5 & 11.0 & 0.1 & 87.3 & 11.4 & 73.6 & 1.5 & 60,086 \\
\hline $\begin{array}{l}\text { Six-year Secondary } \\
\text { National Schools }\end{array}$ & 15.8 & 3.0 & 12.8 & - & 84.2 & 22.6 & 59.0 & 2.1 & 247 \\
\hline Primary & 85.0 & 13.9 & 70.7 & 0.4 & 15.0 & 0.6 & 11.2 & 3.1 & 1,763 \\
\hline Lower Secondary & 65.1 & 17.2 & 47.2 & 0.7 & 34.9 & 3.6 & 28.3 & 2.5 & 1,640 \\
\hline Upper Secondary & 36.1 & 16.2 & 19.6 & 0.3 & 63.9 & 26.9 & 36.5 & 0.3 & 594 \\
\hline Six-year Secondary & 31.4 & 18.6 & 12.8 & - & 68.6 & 23.3 & 45.3 & - & 87 \\
\hline
\end{tabular}

${ }^{6}$ As of April 1, 2006, there are 713 four-year colleges and universities (83 national, 74 public and 666 private ones) and 468 junior colleges (7 national, 40 public and 421 private ones) in Japan. Among these, those which have accredited teacher training programs are 570 four-year colleges and universities (79.9\%) consisting of 77 national, 44 public and 449 private universities $(92.8 \%, 59.5 \%$ and $80.8 \%$ respectively), and 280 junior colleges $(59.8 \%)$ of which 14 are public and 266 are private (35.9\% and $63.2 \%$ respectively).

${ }^{7}$ Japanese Ministry of Education, 2004. 
Table 4

PERCENTAGE of Secondary School Classes Taught by a teacher without a Certificate in the Field, by subject, 2004 ${ }^{8}$

\begin{tabular}{|lcccc|}
\hline & \multicolumn{2}{c}{ Junior High School } & \multicolumn{2}{c|}{ Senior High School } \\
\hline & \# of Classes & \% of Classes & \# of Classes & \% of Classes \\
\hline Japanese Language & 652 & 0.6 & 41 & 0.0 \\
Social Studies & 671 & 0.6 & 357 & 0.4 \\
Mathematics & 1300 & 1.1 & 214 & 0.2 \\
Science & 363 & 0.3 & 65 & 0.1 \\
Music & 178 & 0.2 & 4 & 0.0 \\
Fine Arts & 1682 & 1.4 & 154 & 0.2 \\
Health and Physical Ed & 1311 & 1.1 & 104 & 0.1 \\
JrHi: Indus. Arts & & & & \\
SrHi: Info Tech & 2358 & 2.0 & 395 & 0.4 \\
Home Economics & 2644 & 2.2 & 165 & 0.2 \\
English & 411 & 0.3 & 100 & 0.1 \\
JrHi: Other & & & & \\
SrHi: Vocational & 7 & 0.0 & 1713 & 1.7 \\
Total & 11577 & 1.1 & 3313 & 0.9 \\
\hline
\end{tabular}

${ }^{8}$ Japanese Ministry of Education National Data, 2004.

majority of their teachers from general colleges and universities at all three levels of schooling.

\section{Out-of-Field Teaching}

Ingersoll in his chapter refers to "outof-field" teaching as a problem in the United States that adversely affects the quality of teaching. Table 4 is interesting in that it presents a very divergent picture regarding "out-offield teaching" when comparing the United States and Japan. It shows that such a problem is seemingly not of great significance in Japan.

Table 4 lists the number and percentage of classes, not the number of teachers, which is used as the indicator in the United States. Although no such national data is available in Japan, Table 5 presents such data for Niigata prefecture. None of these statistics can be described as alarming. For the core courses, the percentage of classes taught by "outof-field" teachers is negligible. The teacher certification system in Japan assures that teachers should teach the subjects they have been trained to teach. The numbers here are low and reflect "emergency" personnel decisions where a teacher may teach classes outside of his/her field as a last resort when a teacher from that field is not available. Nevertheless, this occurrence is rare.

Despite the infrequency of out-offield teaching, there are some arguments and complaints from teachers on the issue of out-of-field teaching. Especially in the small junior high schools with one or two classes at each grade level, the number of teachers is small, and accordingly, some teachers are forced to teach a subject that is not in their field, which makes them feel uncomfortable, imposed upon, and needlessly busy. This is one reason why the consolidation of small schools has become one reform policy.

\section{The Teaching Profession in Japan}

\section{Job Conditions and Retention Rates} Ingersoll in his chapter on teaching in the United States points to teacher retention rates as a major factor
Table 5

PERCENTAGE of Secondary School Teachers Who Teach Classes Without a Certificate in the Field, by Subject, $2004^{9}$

$\begin{array}{lr}\text { Japanese Language } & 2.3 \% \\ \text { Social Studies } & 2.6 \% \\ \text { Mathematics } & 5.2 \% \\ \text { Science } & 1.9 \% \\ \text { Music } & 0.7 \% \\ \text { Fine Art } & 11.2 \% \\ \text { Health \& Physical Education } & 2.8 \% \\ \text { Industrial Arts } & 36.3 \% \\ \text { Home Economics } & 34.8 \% \\ \text { English } & 2.6 \%\end{array}$

${ }^{9}$ Niigata Prefecture Board of Education homepage, Prefectural data, 2004

affecting teaching quality. Training teachers who leave the profession defeats the purpose. Training is the first step in providing quality teaching. Next, the well-trained teaching workforce must continue to provide a high level of education based on the expertise and knowledge they have acquired in their training and teaching experiences. Thus it is necessary to examine and discuss teacher retention rates in Japan. Table 6 presents data that would suggest that teacher retention rates in Japan are a positive aspect of Japanese education and the culture of teaching.

The statistics indicate that the majority of teachers remain in the teaching profession and only leave it at retirement age. The number of teachers who cited job change as a reason for leaving was comparatively very low. These statistics would seem to indicate that the teaching profession is an attractive profession in Japan that is competitive with other career alternatives. There are a number of factors that contribute to the attractiveness of the teaching profession, and monetary incentives and financial security always figure prominently in any job choice. The 
Table 6

PERCENTAGE of Retired Teachers in Japan, by Reason of Retirement, 2004 ${ }^{10}$

\begin{tabular}{|c|c|c|c|c|c|c|c|c|c|}
\hline & $\begin{array}{c}\text { Total } \\
\text { Teachers }\end{array}$ & $\begin{array}{c}\text { Total } \\
\text { Retires }\end{array}$ & $\begin{array}{c}\% \text { of } \\
\text { Retires }\end{array}$ & $\begin{array}{c}\text { retiring } \\
\text { age }\end{array}$ & disease & death & job change & $\begin{array}{l}\text { admission } \\
\text { to schools }\end{array}$ & other \\
\hline Total & 934,230 & & & & & & & & \\
\hline Primary & 407,598 & 9,319 & $2.3 \%$ & $63.1 \%$ & $2.3 \%$ & $2.3 \%$ & $8.2 \%$ & $0.2 \%$ & $23.9 \%$ \\
\hline Public Schools & 402,579 & 9,128 & $2.3 \%$ & $63.9 \%$ & $2.3 \%$ & $2.3 \%$ & $8.1 \%$ & $0.2 \%$ & $23.2 \%$ \\
\hline \multicolumn{10}{|l|}{ Lower } \\
\hline Secondary & 257,605 & 6,929 & $2.7 \%$ & $54.4 \%$ & $2.0 \%$ & $2.4 \%$ & $14.2 \%$ & $0.6 \%$ & $26.4 \%$ \\
\hline Public Schools & 243,680 & 6,308 & $2.6 \%$ & $57.6 \%$ & $2.0 \%$ & $2.4 \%$ & $14.0 \%$ & $0.4 \%$ & $23.7 \%$ \\
\hline \multicolumn{10}{|l|}{ Upper } \\
\hline Secondary & 269,027 & 10,313 & $3.8 \%$ & $65.2 \%$ & $2.0 \%$ & $2.2 \%$ & $8.5 \%$ & $0.6 \%$ & $21.6 \%$ \\
\hline Public Schools & 206,236 & 6,953 & $3.4 \%$ & $80.3 \%$ & $1.3 \%$ & $2.3 \%$ & $5.1 \%$ & $0.3 \%$ & $10.8 \%$ \\
\hline Private Schools & 62,190 & 3,341 & $5.4 \%$ & $33.7 \%$ & $3.6 \%$ & $2.0 \%$ & $15.6 \%$ & $1.1 \%$ & $44.1 \%$ \\
\hline
\end{tabular}

${ }^{10}$ Japanese Ministry of Education National Data, 2004

Table 7

PERCENTAGE of School Teachers in Japan, by Monthly Salary (Unit: 10T=100,000), 2004 ${ }^{11}$

\begin{tabular}{|c|c|c|c|c|c|c|c|c|c|c|}
\hline & $-10 \mathrm{~T}$ yen & $\begin{array}{c}10-15 \mathrm{~T} \\
\text { yen }\end{array}$ & $\begin{array}{c}15-20 \mathrm{~T} \\
\text { yen }\end{array}$ & $\begin{array}{c}20-25 \mathrm{~T} \\
\text { yen }\end{array}$ & $\begin{array}{c}25-30 \mathrm{~T} \\
\text { yen }\end{array}$ & $\begin{array}{c}30-35 \mathrm{~T} \\
\text { yen }\end{array}$ & $\begin{array}{c}35-40 \mathrm{~T} \\
\text { yen }\end{array}$ & $\begin{array}{c}40-45 \mathrm{~T} \\
\text { yen }\end{array}$ & $\begin{array}{c}\text { 45Tyen- } \\
\text { yen }\end{array}$ & $\begin{array}{c}\text { Mean } \\
\text { (1000yen) }\end{array}$ \\
\hline \multicolumn{11}{|l|}{ Public Schools } \\
\hline Primary & 1.7 & 0 & 0.2 & 4.3 & 6.2 & 12.3 & 22.3 & 29.6 & 23.5 & 389.2 \\
\hline Lower Secondary & 1.2 & 0 & 0.3 & 5.3 & 8 & 14.2 & 28.1 & 24.3 & 18.4 & 377.9 \\
\hline Upper Secondary & 0.9 & 0 & 0.3 & 4.9 & 7.1 & 11.6 & 22.9 & 23 & 29.3 & 393.5 \\
\hline $\begin{array}{l}\text { Six-year Secondary } \\
\text { Private Schools }\end{array}$ & - & - & - & 8.1 & 5.4 & 35.1 & 29.7 & 10.8 & 10.8 & 356.6 \\
\hline Primary & 1.5 & 0.4 & 2.6 & 14.4 & 14.4 & 13.2 & 13.1 & 14 & 26.5 & 364.7 \\
\hline Lower Secondary & 0.7 & 0.2 & 1.7 & 11.5 & 13.8 & 13.3 & 13.8 & 13.8 & 31.2 & 385.4 \\
\hline Upper Secondary & 0.6 & 0.2 & 2.5 & 10.5 & 10.4 & 11.4 & 14.3 & 15.7 & 34.4 & 391.7 \\
\hline $\begin{array}{l}\text { Six-year Secondary } \\
\text { National Schools }\end{array}$ & 9.4 & 4.7 & 20.3 & 32.8 & 15.6 & 3.1 & 6.3 & 1.6 & 6.3 & 229.4 \\
\hline Primary & 0.4 & - & 0.1 & 2.1 & 7.1 & 30.6 & 42.9 & 10.7 & 6 & 358.8 \\
\hline Lower Secondary & 0.2 & - & 0.1 & 1.4 & 7 & 23.3 & 47.7 & 13.1 & 7.2 & 366.4 \\
\hline Upper Secondary & 0.8 & - & 0.2 & 1.2 & 3.7 & 12.6 & 26.1 & 30.7 & 24.8 & 400.1 \\
\hline Six-year Secondary & 1.2 & - & 1.2 & 7 & 11.6 & 20.9 & 27.9 & 14 & 16.3 & 358.5 \\
\hline
\end{tabular}

${ }^{11}$ Japanese Ministry of Education National Data, 2004 a. US\$1 = 110 Japanese Yen

following table (Table 7) reveals that public school teachers receive competitive salaries that are even comparable with their counterparts in private schools.

\section{Teachers' Perceptions of Their Profession in Japan in Comparison with China and the United Kingdom}

It should come as no surprise that well paid teachers typically are happier in their professions as educators. But while this trend holds true within each country, it is not necessarily relevant to the crossnational comparison. Attitudes that contribute to a high level of job satisfaction to Japanese teachers can be found in a study comparing the United Kingdom (UK), China, and Japan (Fujita, $2001 \&$ 2006).

Table 8 and Table 9 present the percentage of teachers who answered "accurate" or "accurate to some degree" to the questions concerning the teaching profession and their work lives respectively. These tables are based on the comparative survey conducted by the current author and his colleagues in 2000 for Japan and 2002 for the United Kingdom. Both the English and Chinese questionnaires were translated from the Japanese questionnaire. The UK sample is a representative sample of England, Wales, Scotland and Northern Ireland, while the Chinese sample was drawn from Shanghai and Kunming. The Japanese sample was strategically drawn from 11 major cities in 11 prefectures including Tokyo, considering the 
Table 8

Teachers' Perceptions of the Teaching Profession - PERCENTAGE of those who answered "accurate" or "accurate to some degree."

\begin{tabular}{lccc} 
& Japan & China & UK \\
\hline 1. Constant efforts has to be made to improve oneself & 98.6 & 99.6 & 97.3 \\
2. Requires highly professional knowledge and skills & 93.5 & 95.8 & 99.1 \\
3. Financially secure with good benefits & 43.1 & 51.5 & 52.5 \\
4. Have high social status & 42.3 & 70.0 & 17.4 \\
5. Involved with every aspect of students' personality & 73.9 & 88.8 & 55.5 \\
6. Exploits one's own life extensively & 78.2 & 88.1 & 77.4 \\
7. Teachers are the models of life for the children & 57.7 & 94.6 & 71.3 \\
8. Teachers are intellectuals & 56.5 & 94.0 & 71.3 \\
9. Teachers are professionals & 92.3 & 67.9 & 98.0 \\
10. Enjoy wide range of autonomy in designing work & 56.5 & 46.2 & 94.9 \\
11. Have to maintain a relationship of authority towards pupils & 68.4 & 84.8 & 97.5 \\
12. Physically demanding & 98.9 & 95.3 & 96.6 \\
13. Must have a sense of mission & 92.4 & 94.0 & 92.4 \\
14. Gives a feeling of accomplishment & 94.0 & 91.3 & 89.6 \\
Total number of respondents (sample size) & 1277 & 726 & 1382
\end{tabular}

Table 9

Teachers' perceptions of their work lives - PERCENTAGE of those who answered "Yes" or "Sometimes."

\begin{tabular}{|lccc|}
\hline & Japan & China & UK \\
\hline 1. Happy to have become a teacher & 88.3 & 77.2 & 92.3 \\
2. Tired chronically & 79.4 & 93.1 & 88.5 \\
3. Authority of teachers is declining & 88.8 & 70.2 & 96.5 \\
4. Busy everyday & 96.6 & 97.5 & 99.9 \\
5. Want to quit teaching & 29.5 & 24.0 & 55.1 \\
Total number of respondents & 1277 & 726 & 1382 \\
\hline
\end{tabular}

diversity of the localities throughout Japan (Fujita, $2001 \&$ 2006). As for the Japanese survey, a similar survey was conducted with focus on the organizational culture and work lives in 1995 in eight cities, all of which are included in the survey of this study (Fujita, 1997). The results presented here are substantially similar to those of the previous one.

Table 8 is interesting in that it suggests at least three trends.

First, all three countries show very high percentages, over $90 \%$, in items $1,2,6,12,13$ and 14 . This suggests that these aspects are the basic features of teaching profession. Teaching is a kind of job or profession that is physically demanding and tends to exploit teacher's own life extensively. It also requires a sense of mission, high expertise and constant efforts to
Third, as shown in the items 7 and 8 , such images as "models of life for the children" and "intellectuals" also differ among these three countries, with both of the images most pervasive in China, least in Japan and in-between in the UK. On the other hand, such perceptions as "financially secured with good benefits" and "have to maintain a relationship of authority toward pupils" are most pervasive in the UK, least in Japan, and China in between.

Among these three, the third points are especially suggestive for understanding current conditions of Japanese teachers and the impacts of recent reform policies. Japan is lowest in all of these four aspects: "models of life," "intellectuals," "to maintain authority toward pupils," and "financial security." Why is Japan lowest among these three countries? To answer this question, the following section provides a brief explanation of recent education reform trends in Japan.

\section{Impacts of Recent Education Reform on Teachers' Perceptions in Japan}

Responding to the survey, Japanese teachers displayed a moderate degree of feelings of financial security that is slightly lower than teacher responses in the UK and China. This is not surprising as Japan has the highest cost of living in the world. In addition, there is a possibility that it reflects the recent decline of competitive salaries of public school teachers compared to employees holding a bachelor's degree in their major and working for a private company. The decline in salaries is due partly to cutbacks in salaries and fringe benefits, as well as education policies that have led to intensification of teaching job. 
Secondly, Japanese teachers tend not to think of themselves as intellectuals and the role models for children compared with their counterparts of UK and China. Theoretically, it can be said that these perceptions should be higher in less developed societies and should tend to decline along with the socio-economic development and educational expansion. Then a question arises: Why is it significantly lower in Japan than even in UK? One possible answer is such that university education has expanded more in Japan than in UK countries and accordingly there are more BA degree holders among parents and ordinary people in Japan. It also is plausible that the cultural urbanization has advanced more in Japan than in UK countries and accordingly the traditional culture of respecting teachers has declined more. A further answer is that Japanese schools and teachers, especially public schools and their teachers, have been under relentless attack from various stakeholders since the 1980s and forced by reform policies to become efficient in some specific aspects such as school disorder problems. As a result, many teachers have become confused trying to make sense of their roles and lost confidence in being teachers, intellectuals and role models for children.

Finally, Japanese teachers displayed a moderate degree of feelings about the importance of maintaining a relationship of authority towards pupils, much lower than those of UK and China. It is correct to say that this is deeply related to the educational reform movements and policies over the last three decades in Japan. Especially since the 1980s, progressive and child-centered ideas of teaching and learning have been spread and emphasized in Japan. In 1980, the revised national course of study was enforced and the policy called Yutorikyoiku (education free from stress) was started, cutting down lesson hours and educational content and emphasizing a new conception of academic ability, a new progressive style of learning and a new scheme of academic assessment, with the slogan of "Yutori (affordability) and Jujitu (enjoyable fulfillment)." This policy has been further strengthened by the five-day school week policy, which was partly implemented in 1992 and fully in 2002, giving up Saturdays as a school day ${ }^{12}$.

These various policies, however, have come under criticism since around 2000, and reactionary reform initiatives are being taken under the current administration as of January 2007. The steps being taken include expansion of the parental choice scheme and selective six-year public secondary schools, the introduction of the national test for all sixth and ninth graders and a school evaluation scheme, introduction of the renewal system for teacher certificates, and the emphasis on indoctrinatory moral education and severe punishment of disorderly behaviors. Most of these plans are criticized by the current author and other education scholars/critics for reasons including deteriorating further Japanese education and practical and moral bases of teaching and teachers' collaboration as well as expanding the differences of educational opportunity by family backgrounds (Fujita, 1997, 2000, 2005, 2006 \& 2007; Hirota, 2004; Kariya, 2002 \& 2007; Mimizuka, 2007). It is right to say that these reform movements and policy discourse lie behind the unique perceptions of Japanese teachers mentioned above.

${ }^{12}$ The backgrounds, contexts and impacts of these policies like "Yutori-kyoiku" and "five-day school week" are investigated and discussed in Fujita's books and articles (Fujita, 1994, 1997, 2000, 2005 and others).

\section{Teachers' Perceptions of Their Work Lives in Japan in Comparison with China and the United Kingdom}

Table 9 shows teachers' perceptions of their work lives in Japan, China and the UK. The data come from the same survey used for Table 8 .

Almost all teachers of all three countries feel "busy every day," and most teachers also feel "tired chronically," indicating that the intensification of the teaching job is now a common feature in many countries. Most teachers also feel "happy to have become a teacher" (happy to be a teacher, hereafter). They also agree "the authority of teachers is declining" (authority decline, hereafter), but the percentages vary significantly among the three countries: UK is highest, Japan is next and China is lowest. The most striking results is the differences in the feeling of "want to quit teaching" among these three countries: more than half of UK teachers indicate a desire to leave the profession, while in Japan only about $30 \%$ indicate such a desire and only $24 \%$ in China.

Why do these differences appear? Although it is not easy to identify their causes or backgrounds, the following tables (Tables 10 to 12 ) provide some evidence for feasible speculation. These tables are the summary results of regression analyses, the dependent variables of which are the feelings of "authority decline," "happy to be a teacher" and "want to quit teaching," respectively.

Although there are some differences among these three countries, major determinants and patterns basically are similar. In all three countries, teachers tend to feel the decline of their authority, if they feel that mass media tend to criticize the schools and teachers unduly 


\begin{tabular}{|c|c|c|c|}
\hline \multicolumn{4}{|c|}{$\begin{array}{l}\text { Table } 10 \\
\text { Determinants of the feeling of "authority of teachers is declining." }\end{array}$} \\
\hline Independent variables & Japan & China & UK \\
\hline $\begin{array}{l}\text { Mass media do not understand th } \\
\text { everyday experience of schools }\end{array}$ & .203 & .217 & .218 \\
\hline Fearful of students & .161 & .182 & .160 \\
\hline Parents report complaints often & .144 & .178 & - \\
\hline $\begin{array}{l}\text { Teachers have to maintain a relati } \\
\text { of authority toward students }\end{array}$ & .112 & - & .085 \\
\hline $\mathrm{R} 2$ & .126 & .152 & .094 \\
\hline Analysis of variance & 4 & 3 & 3 \\
\hline F-value & 43.9 & 39.3 & 39.8 \\
\hline Probability of significance & .000 & .000 & .000 \\
\hline
\end{tabular}

Table 11

Determinants of the feeling of "happy to have become a teacher."

\begin{tabular}{|c|c|c|c|}
\hline Independent variables & Japan & China & UK \\
\hline Teaching gives the feeling of accomplishment & .515 & .455 & .440 \\
\hline Teachers have high social status & - & .121 & .129 \\
\hline $\begin{array}{l}\text { Staying in touch with students } \\
\text { whom you taught before }\end{array}$ & .102 & - & - \\
\hline $\begin{array}{l}\text { Talking about your own experience of life } \\
\text { and your philosophy to students }\end{array}$ & .086 & - & - \\
\hline $\begin{array}{l}\text { Discussing educational viewpoints } \\
\text { and directions with colleagues } \\
\text { R2 }\end{array}$ & $\overline{.326}$ & $\overline{.255}$ & $\begin{array}{l}.074 \\
.253\end{array}$ \\
\hline $\begin{array}{r}\text { Analysis of variance } \\
\text { F-value } \\
\text { Probability of significance }\end{array}$ & $\begin{array}{c}3 \\
195.1 \\
.000\end{array}$ & $\begin{array}{c}2 \\
114.0 \\
.000\end{array}$ & $\begin{array}{c}3 \\
148.7 \\
.000\end{array}$ \\
\hline
\end{tabular}

${ }^{13}$ Regression analysis; values $=\beta$; all values are significant $=.002$

Table 12

Determinants of the feeling of "want to quit teaching." 12

\begin{tabular}{|c|c|c|c|}
\hline Independent variables & Japan & China & UK \\
\hline Happy to have become a teacher & -.516 & -.461 & -.496 \\
\hline Authority of teachers is declining & - & .255 & .199 \\
\hline Busy every day & - & .117 & .072 \\
\hline Tired chronically & .285 & - & .179 \\
\hline $\mathrm{R} 2$ & .402 & .359 & .449 \\
\hline Analysis of variance & 2 & 3 & 3 \\
\hline F-value & 418.0 & 124.0 & 361.9 \\
\hline Probability of significance & .000 & .000 & .0002 \\
\hline
\end{tabular}

${ }^{14}$ Regression analysis; values $=ß$; all values are significant at .000

without understanding the reality of schools, and if they feel fearful of students. In other words, these days teachers feel their authority declining, partly due to the growing undue criticism of teachers in policy discourse and society at large, and partly due to the increase of such school-disorder problems as authority declining more than those who do not feel the need to hold firm authority. In short, these results suggest that increasingly harsh conditions surrounding teachers both within and outside schools make teachers feel their authority declining.

As for the feeling of "happy to be a teacher," in all three countries that disposition depends mostly on the feeling of accomplishment experienced through teachingreflecting the nature of teaching profession and its associated reward. This connection is more prominent in Japan than in China and UK, as indicated in the above table. Not only the feeling of accomplishment but also the two other variables, "staying in touch with students whom you taught before" and "talking about your experience of life and your philosophy to students," have statistically significant impacts on the feeling of "happy to be a teacher," and these three variables combine to explain about $33 \%$ of its variance. On the other hand, in China and the UK, the second largest determinant is teachers' social status, which is not significant in Japan.

The final question to be investigated here is why many teachers, especially in the UK, indicate a desire to leave the profession. The most powerful, negative determinant is to be found in the response to the feeling of "happy to be a teacher": If he or she feels happy to have become a teacher, he or she is not likely to have such a desire. On the other hand, the feelings of "authority decline" and "busy every day" tend to match teachers' desires to leave the profession in China and the UK, and the feeling of "tired chronically" also tends to do so in the UK. In Japan, however, not the feeling of "busy every day" itself but the feeling of 
"tired chronically" has a much larger impact in causing them to desire to leave the profession. As indicated in Table 8, the profession these days is extremely busy and physically demanding for a teacher, and tends to exploit one's own life extensively. But at least in Japan, these features are not critical for making teachers feel unhappy in being a teacher and desire to leave the profession. It is such factors as the feeling of "tired chronically," partly caused by relentless undue criticism and attacks against teachers and schools, that make teachers unhappy, isolated, hopeless, and desiring to leave the profession. This is the case at least in Japan.

\section{Implications and Conclusions}

As referred to in the study on teacher attitudes and perceptions, Japanese teachers see themselves as professionals who have a sense of pride in their professions. Japanese teachers enjoy a career that provides them with a handsome pay scale, job autonomy, high sense of accomplishment, and a collaborative community with their colleagues that affords them chances to grow and develop as educators.

Because of the well-regulated guidelines governing teacher certification, Japanese teachers are well-trained in the appropriate subject matter and pedagogical courses. The data in Tables 4 and 5 attest to the fact that "out-of-field teaching" is not a significant factor affecting the quality of teaching in Japan. Furthermore, the data on retirement suggests that job retention in the teaching profession in fairly stable. A further indication of job retention is the statistic that only $0.6 \%$ of teachers leave the profession after their first year of service. This is far preferable to a situation like that in the United States where fully 40$50 \%$ of teachers leave the profession in the first five years of service (see Ingersoll chapter). The current statistics in Japan regarding teacher professionalism, quality teaching, and retention of teachers paint a positive picture.

As proved especially in Tables 6 and 9, it also is abundantly clear that Japanese teachers are happy in their profession as educators. Furthermore, despite the challenges, they do not indicate a desire to leave the profession, an attitude that explains most directly the exemplary rate of teacher retention in Japan. The Japanese teaching profession still remains an attractive option for college students in Japan.

Nevertheless, there is the possibility that "reformism" for the sake of change will lead to drastic changes in the profession and the way it is viewed. Some political actors in Japan would seek to meddle in the field of education reform, putting political gain ahead of social progress. The teaching profession and educators stand at a crossroads where they must lead the field of education in the direction they see fit resisting the chaotic winds of reform that constantly change direction.

Since the 1980s a tide of education reform movements has emerged in many countries including the United States, the United Kingdom, and Japan and reframed the policy discourse on evaluating and organizing public education. This new framework has placed more emphasis on freedom rather than equality, and quasi-public (or superficial) accountability rather than responsibility for our children and community. More confidence has been vested in market efficiency rather than intrinsic educational value, and direct managerial control rather than the professional expertise of autonomous teachers.

Policymakers have looked only toward narrow-sighted, short-term, and measurable outcomes to the detriment of broadly viewed, longterm functions and effects of education. In this changing environment, teachers and schools have been under relentless attack from various stakeholders and forced to cope with the growing pressures from backers of the principles of market efficiency and quasi-public accountability that are embodied in the policies favoring parental choice of schools, "testism," the audit culture, and achievement-oriented teacher evaluation and rewarding systems.

The rapid pace of reforms and the normative tone of the dominant reform discourse have cast a shadow over more viable approaches and policies based on research and empirical evidence. Policymakers, the mass media, and practitioners have become shortsighted and hasty in making changes and getting concrete results (Fujita 1997, 2000a, 2000b, 2005, 2006, \& others). Researchers must keep the needs and expectations of practitioners in mind when planning research which seeks to help improve the quality of teaching and education, especially in the current climate where confidence and trust in teachers has been eroded by reformers and critics who know little of the realities of education in schools. Practitioners and researchers must work in tandem to forge a new collaborative community bridging the divisions between universities, schools, and research institutes.

The ideologies behind reformism are wrought with irony and illogical. The current reform initiatives and proposals seek to address crises that do not exist and rather will give rise to unforeseen educational crises. 
Stakeholders must ask themselves if there is a need for reform after close examination of the realities of education. This examination must be a transparent process that is based in the values of justice and trust. The current reform trends will undermine the ideal of equal schooling for all as well as that of a collaborative community of educators who create a holistic learning and caring educational space. Thus, by infringing upon the autonomy of teachers, these reforms have the greater danger of lessening the attractiveness of the teaching profession and adversely affecting the quality of teaching in Japan.

Time is of the essence for the stakeholders in Japanese education to avoid an educational crisis brought on by the forces of reformist dilettantism. Choices must be made that will have a significant effect on the quality of teaching for decades to come. Is quality teaching assured by control and inspection, or by imbuing teachers with democratic autonomy and professionalism? The answers to these questions can only come from an approach to policy discussion and practice based in methodologically rigorous research that provides reliable results to lay at the foundation of future policybuilding. Only thus can education uphold the values of trust and dignity to the benefit of all those involved in the educational endeavor. 


\section{References}

Fujita, H. (1997). Kyoiku-Kaikaku [Education Reform]. Tokyo:IwanamiShoten.

Fujita, H. (1999, January 18-21). Choice, quality and democracy in education: A comparison of current educational reforms in the United States, the United Kingdom and Japan, Paper presented at the international symposium on The Public and the Private in the United States sponsored by the Japanese Association for American Studies and the Japan Center for Area Studies of the National Museum of Ethnology, held in Osaka, Japan. Retrieved February 13, 2007, from http://www.childresearch.net/RESOUR CE/RESEARCH/200O/FUJITA/index. html

Fujita, H. (1999, February 26-28). Today's juvenile problem and educational reform in Japan: Its reappraisal and future implications, Paper presented at the Japan-United States Conference on Juvenile Problems and Violence in a Changing Society held in Tokyo, Japan. Retrieved February 13, 2007, from

http://www.childresearch.net/RESOUR CE/RESEARCH/1999-

1998/FRIEND/index.html

Fujita, H. (2000a). Education reform and education politics in Japan. The American Sociologist, 31(3), 42-57.

Fujita, H. (2000b). Shimin-Shakai to Kyoiku [Civic society and education]. Seori-Shobou.
Fujita, H. (2005). Gimukyoiku o Toinaosu [Reappraisal of compulsory education]. Chikuma-Shobou.

Fujita, H. (2006). Kyoiku-kaikaku no Yukue [Where is education reform going?]. Iwanami-Shoten.

Fujita, H., \& Wang, S.-Y. (1997). Teacher professionalism and the culture of teaching in Japan: The challenge and irony of educational reform and social change. In $\mathrm{H}$. Fujita, (Ed.), A study on the culture of teaching and teacher professionalism. Tokyo: Tokyo University Press.

Fujita, H., \& Wong, S-K. (1999). Postmodern restructuring of the knowledge base in Japanese mass education: Crisis of public culture and identity formation. Education Journal, 26(2), 27(1), pp. 37-53. The Chinese University of Hong Kong. Japanese Ministry of Education homepage.

Niigata Prefecture Board of Education homepage, Prefectural data, 2004.

Stevenson, H.W., \& Stigler, J.W. (1992). The learning gap: Why our schools are failing and what we can learn from Japanese and Chinese education. New York: Summit Books. 


\title{
CHAPTER 5
}

\section{The Quality and Qualifications of the Teaching Force In the Republic of Korea}

\author{
Ee-gyeong Kim \\ Korean Educational Development Institute
}

\section{Introduction}

Korea has recently seen an unprecedented interest in teachers as the most important factor influencing student achievement, which naturally yields a conclusion that the quality of teachers ought to be improved in order to raise the quality of education. The worldfamous educational zeal of Korean parents-expressed through excessive spending on private tutoring - has given rise to distrust of public education and dissatisfaction with public school teachers. Although the Korean government since the 1990s has made policy efforts aimed at revitalizing public schooling and improving the quality of the teaching force, a sense of crisis based on a notion that qualified and dedicated teachers are in short supply in schools is gaining even stronger currency.

To improve the quality of teachers, it takes a coherent policy effort that integrates the entire teaching career-that is, from the point at which aspiring teachers enter a teacher training institution until they reach retirement. There should be systematic and comprehensive efforts to improve professionalism and quality of teachers at each phase of the teaching career: When attracting talented persons to teaching and preparing them for the job; when employing and placing them; and in their early career and the subsequent service period. That is because teacher quality cannot be enhanced by focusing on only a single career phase.

Nevertheless, the phases that receive particular attention in Korea are teacher preparation and certification due to a unique attribute of Korea's teacher labor market. In Korea, relatively competitive individuals in the labor market aspire to enter teaching profession. Teaching is considerably favored by the Korean youth because of its distinct merit of guaranteed tenure, particularly in the current age of employment instability, and its traditionally upheld social status. Also, the teacher turnover rate is very low, so that most teachers remain in the profession until the point of retirement. Thus, for the goal of having as many high quality teachers as possible in schools, a crucial matter is how to prepare and certify the competitive individuals who intend to enter the teaching profession in such a way that they consequently form a high-quality teaching force. Hence, it is natural that national attention is being paid to the system of teacher preparation and certification.

At this juncture, the definition of teacher quality should be examined. In an Organization for Economic Cooperation and Development OECD (1994) study reviewing the concept of teacher quality comprehensively and systematically, teacher quality is defined in the following five dimensions: first, knowledge of curriculum and content of education; second, pedagogical skill including attainment of diverse instructional strategies and the ability to utilize them; third, self-reflection and selfcriticism that ensure teacher professionalism; fourth, empathy and commitment that recognize dignity of other persons; and fifth, the management skills required to manage the affairs in and out of classroom.

Depending on what qualities of a person should be viewed as constituting an ideal teacher, the goal of teacher preparation as well as the design of teacher training may vary. For example, the ratio between subject-specific pedagogy and training in subject matter content, the ratio between general pedagogy and subject matter training, and the 
period and method of practice teaching could vary. Although the state supervises teacher certification in Korea, there exists no agreed-upon national standard as to the educational curriculum of teacher preparation. Thus, curricular organization and required hours vary among different teacher training institutions, thereby inhibiting effective quality control of the preparation phase.

Another important issue at hand in the discussion of securing a highquality teaching force is that of the balance between supply and demand of teachers. At present, in Korea, there is an undersupply of teachers for elementary schools, so that the quality as well as suitability for a school's needs of the candidates for teaching positions cannot be reviewed at a satisfactory level. In the case of secondary schools, oversupply of teachers has resulted in a large excess of unemployed teaching certificate holders produced by teacher training institutions. Such undersupply and oversupply are deeply related to the types of teacher training institutions. While elementary school teachers are trained nation-wide at designated institutions designed for the purpose of supplying elementary school teachers, secondary schools teachers are trained at both purpose-based teacher training institutions and other open tertiary institutions. The Korean government has failed to adjust the freshmen quota of those divergent teacher training institutions in a way that matches the demand for teachers, which has resulted in the proliferation of the training institutions for secondary school teachers, consequently creating the problem of teacher oversupply.

Both oversupply and undersupply of teachers can cause the lowering of the quality of teachers and quality of schooling; therefore, it is very important to design a flexible policy for teacher supply. When an oversupply of teachers occurs, both the personal and social costs increase, since graduates of teacher-training institutions cannot find employment as teachers. In addition, an excess of aspiring teachers in teacher training institutions creates difficulties in providing specialized training to them and reduces their opportunities for practice teaching, so the likelihood of lowering the quality of teacher preparation increases. When an undersupply of teachers occurs, teacher candidates who have not undergone the regular processes of preparation, certification, and selection may be employed, or outof-field teachers may be employed, or teacher shortages may be handled by increasing the workload of the existing teachers. Those outcomes increase the likelihood of deteriorations both in teacher quality and the work environment (Santiago, 2002).

The governance structure of Korea's education is very centralized. Like that of the general administration, educational administrative organization is based on three levels of structure--central, intermediate, and the local. There is the Ministry of Education and Human Resources Development at the central level, and there are 16 Metropolitan and Provincial Offices of Education at the intermediate level, and 180 Regional Offices of Education at the local level. Under those administrative jurisdictions, as of 2005 , there were a total of 6,499,518 students and 304,097 teachers in 9,003 national/public elementary and secondary schools; and 1,296,883 students and 76,292 teachers in 1,673 private schools.

The Korean government with its traditionally centralized administrative structure has started to diminish the size of the central administrative organs since the late 1990s, under the banner of making a small and efficient government. Propelled by such an effort at downsizing, the Ministry of Education and Human Resources Development has also been reducing its organization and personnel, concurrently transferring its major administrative decision-making authority including budget planning to intermediate level offices of education. However, inertia within the traditional centralized governance remains powerful, so that the centralized practice is still prevalent in such core dimensions as finance, personnel management, and organizational supervision. Particularly, intermediate and local offices' reliance upon the central government financially is too strong, as evinced by the fact that over $80 \%$ of the local educational expenditure is provided by the central ministry.

The relationship between the offices of education and individual schools also is characterized by its conspicuously top-down manner. Elementary schools and middle schools are supervised by Local Offices of Education, while high schools by Metropolitan and Provincial Offices of Education. Such supervision and control are not restricted to a particular set of designated matters, but can be extended to other matters deemed necessary for normal management of educational institutions and realization of national education goals. Although school-based management was adopted in the mid-1990s for the purpose of giving more autonomy of individual schools, the decision-making authority and scope of local school officials remains limited. 
The formulation and implementation of teacher policies also are under the jurisdiction of the central government; preparation, certification, and employment of teachers are administered by the Ministry of Education and Human Resources Development. Therefore, the scope of influence that can be exerted upon teacher policy by local offices of education and schools is very limited.

\section{Teacher Preparation}

\section{Teacher Preparation System}

A person must acquire a teaching certificate in order to teach at a school, even as a part-time lecturer. In Korea, regardless of the type of teacher training institutions, i.e., either national/public or private, completion of designated courses in nationally accredited teacher training institutions results in conferring of a standard teaching certificate. Those pre-service institutions for elementary and secondary school teachers are separate with different tracks.

Elementary school teachers are trained at 11 national universities of education. These universities of education had been two-year colleges until 1981, when the call for improving the quality of elementary school education upgraded their

Figure 1

Elementary Teacher Training Institutions with Freshmen Quota, 2005 ${ }^{1}$

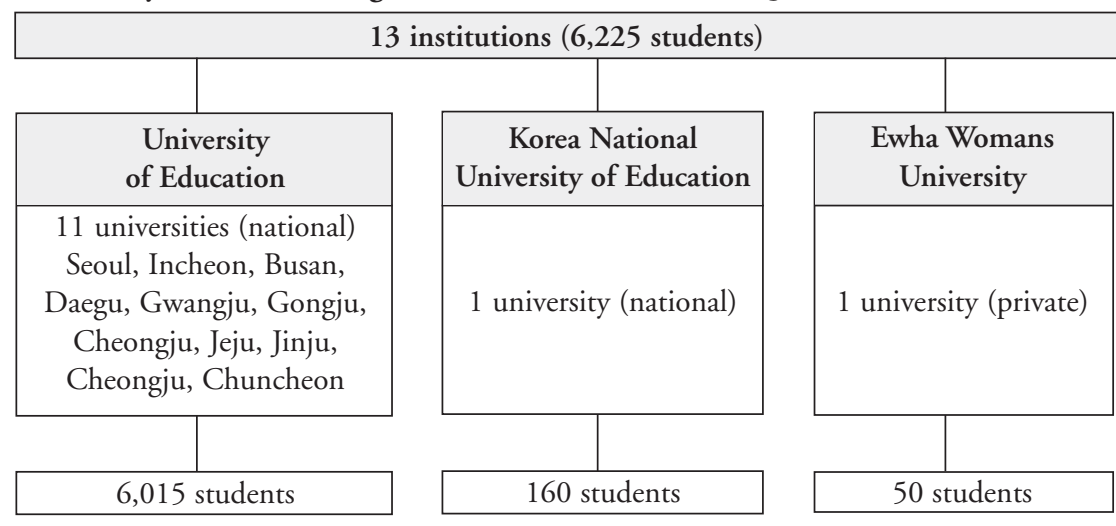

${ }^{1}$ Internal data from Ministry of Education and Human Resources Development

status to that of four-year universities. In addition, there are two departments of elementary school education in the Korea National University of Education and Ewha Womans University, which is a private institution. The following Figure 1 shows the types of training institutions of elementary school teachers and the freshmen quota for the year 2005 .

Secondary school teachers are being trained through various routes, with at least four major paths. They include 40 national and private teachers colleges, 57 departments of education in general universities, 136 teacher training programs in general universities, and 135 graduate schools of education, totaling 368 institutions, which produces over
25,000 graduates every year. The freshmen quota in the teacher training programs and graduate schools of education is bigger than that of teachers colleges. Table 1 shows different types of training institutions of secondary school teachers and the freshmen quota for the year 2005 .

In order to enter the teacher training institutions, applicants need to have educational attainment at least equivalent to that of a high school diploma. The Ministry encourages the applicants' aptitude for teaching and their personality be assessed in the entrance examination, though difficulty in developing an objective and valid assessment tool has made actual implementation of such measures in student selection

Table 1

Secondary Teacher Training Institutions with Freshmen Quota, 2005

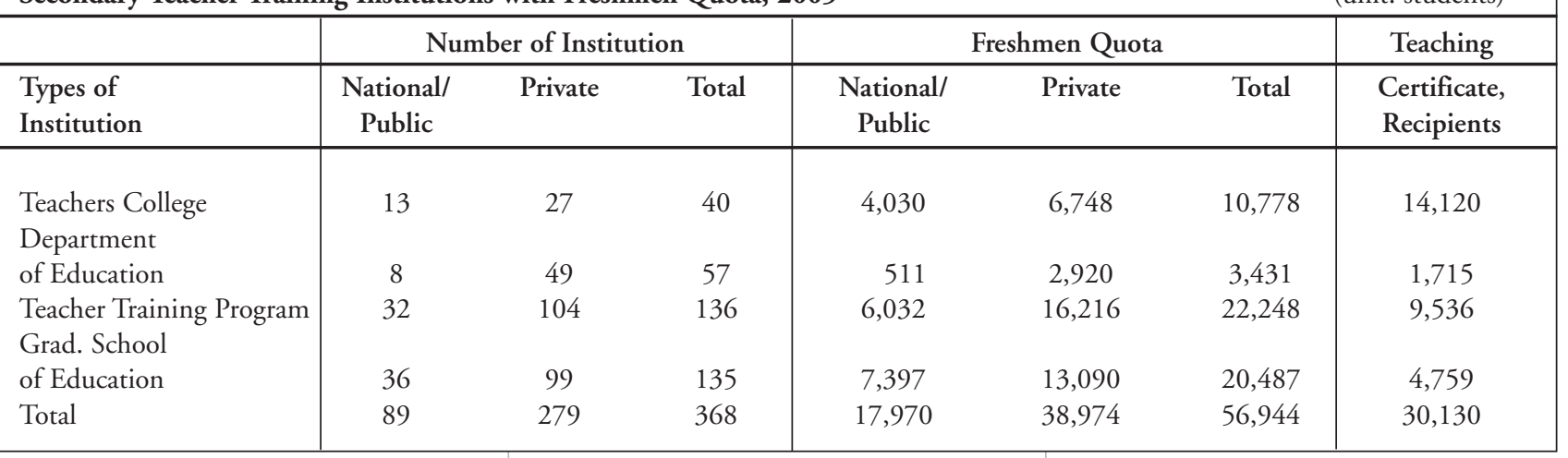


very limited.

Upon graduation, graduates of teacher training institutions are entitled to receive the teaching certificate, and there exists no graduation examination administered at national level. The path through which certified teachers get employed differs between the national/public and private institutions. The Ministry of Education is responsible for the hiring of national and public school teachers, and basic matters such as procedures and methods of the employment test are specified by law. However, superintendents of the 16 Metropolitan and Provincial Offices of Education are delegated by the Education Minster to exercise the authority to employ national and public school teachers (Educational Civil Servant Employment Act, Article number 3). To be employed by national and public schools, a certified teacher must pass the teacher employment test administered by the 16 Metropolitan and Provincial Offices of Education. Since the teacher employment test consists mainly of a paper-and-pencil test covering pedagogical and subjectmatter knowledge, critics often argue that it is of limited value in evaluating the prospective teachers' teaching skills or their aptitude for teaching (Ee-gyeong Kim, et al., 2004).

Meanwhile, in the case of private schools, the methods and procedures for teacher employment are determined by individual school foundations. According to regulations for private school teachers, acquisition of the teaching certificate follows the same regulation for the teachers of national and public schools, but the matters pertaining to teacher employment is decided by individual schools.

Since the number of teachers produced by teacher education

Table 2

Number of Vacancies and Employment Rate (Elementary), 1999-2005. ${ }^{2}$

\begin{tabular}{|lccc|}
\hline Year & Vacancy & Employed & (unit: persons) \\
1999 & 10,026 & 7,825 & 78 \\
2000 & 8,133 & 5,729 & 70.4 \\
2001 & 9,575 & 5,599 & 58.5 \\
2002 & 6,925 & 6,187 & 89.3 \\
2003 & 8,884 & 7,222 & 81.3 \\
2004 & 9,395 & 8,897 & 98.2 \\
2005 & 6,050 & 5,941 & 98.2 \\
\hline
\end{tabular}

${ }_{2}^{2}$ Internal data from Bureau of Teacher Training, Ministry of Education and Human Resources Development.

institutions determines teacher supply, it is closely related to the issue of supply and demand of teachers in the future. In Korea, both phenomena-undersupply and oversupply-are apparent. At the elementary school level, teacher supply is restricted because there are only 13 institutions nationwide. There occurred a temporary shortage after 1999 due to a policy lowering the retirement age for school teachers from 65 to 62 . That resulted in a massive retirement of 22,000 elementary teachers by 2000 , and it took time to replenish the needed teaching force. However, most vacancies had been filled by 2005 , which caused prospective elementary teachers to worry about employability. Recent research on teacher demand and supply revealed there would be an oversupply of elementary teachers starting the year 2011 due to a decrease of student population caused by low fertility rates (Ee-gyeong Kim, et al., 2006). It now is being argued among scholars and practitioners whether to continue efforts to increase the pool of elementary prospective teachers.

In contrast, an oversupply of the secondary school teachers is evident by the low employment rate of certificate holders. In recent years, on average only about $30 \%$ of graduates of the various training institutions of secondary school teachers could find teaching posts; and the employment rate was a mere $16.2 \%$ in 2005 . Such a serious imbalance between supply and demand of teachers goes beyond the simple issue of oversupply of teachers and gives rise to concerns about low-quality teacher education, tending to lower public trust of the teaching profession. Table 2 shows vacancies and employment rate for elementary school teachers, while Table 3 shows the numbers of prepared and employed at the secondary level.

The most serious problem facing teacher-education institutions is their failure to convert excellent human resources into excellent teachers. It is often pointed out that, while excellent students are admitted to teacher-training institutions, those institutions fail to prepare them to be effective teachers. Bluntly, Korea's teacher-preparation process is problematic.

Conspicuous problems in the teacher preparation system are related to the issue of supply and demand of teachers, as well. A rational adjustment should be applied to the undersupply and oversupply of the teaching certificate holders.

Particularly, there should be measures to resolve the problem of oversupply of secondary school teachers and to give intensive, high-quality education to the trainees, whose number should correspond to future demand for teachers. 
Table 3

Ratio Between Preparation and Employment, Secondary School Teacher, 1999-2005. ${ }^{3}$

\begin{tabular}{|lcccccccc|}
\hline Year & \multicolumn{3}{c}{ Preparation $(\mathrm{A})$} & & & Employment (B) & Employment \\
\hline & $\begin{array}{c}\text { Teachers } \\
\text { College }\end{array}$ & $\begin{array}{c}\text { Teacher } \\
\text { training } \\
\text { program }\end{array}$ & $\begin{array}{c}\text { Graduate } \\
\text { school of } \\
\text { education }\end{array}$ & Total & $\begin{array}{c}\text { National/ } \\
\text { public } \\
\text { school }\end{array}$ & $\begin{array}{c}\text { Private } \\
\text { school }\end{array}$ & $\begin{array}{c}\text { Total } \\
\text { Rate } \\
(B / A)\end{array}$ \\
\hline 1999 & 11,297 & 11,731 & 1,737 & 24,765 & 4,277 & 1,268 & 5,545 & $22.30 \%$ \\
2000 & 10,745 & 12,576 & 2,264 & 25,585 & 5,457 & 2,298 & 7,755 & $30.30 \%$ \\
2001 & 10,762 & 11,428 & 3,263 & 25,453 & 2,675 & 1,770 & 4,445 & $17.50 \%$ \\
2002 & 12,931 & 10,448 & 1,887 & 25,266 & 7,388 & 1,235 & 8,628 & $34.10 \%$ \\
2003 & 16,171 & 10,394 & 4,604 & 31,169 & 7,155 & 1,914 & 9,609 & $30.80 \%$ \\
2004 & 17,346 & 9.953 & 4,888 & 32,187 & 5,867 & 1,797 & 7,664 & $23.80 \%$ \\
2005 & 17,273 & 10,483 & 5,417 & 33,173 & 3,980 & 1,384 & 5,364 & $16.20 \%$ \\
Total & 96,525 & 77,013 & 24,060 & 197,598 & 36,799 & 11,666 & 48,465 & $24.50 \%$ \\
\hline
\end{tabular}

Internal data from Bureau of Teacher Training, Ministry of Education and Human Resources Development.

a. Figures in the "National/public school" column indicate the number of people who passed the employment test; Figures in the "Private school" column indicate the number of people who are newly employed.

\section{Teacher Preparation Curriculum}

Teacher preparation in Korea is undertaken not only by institutions specializing in teacher training such as the universities of education for elementary school teachers and teachers colleges for secondary school teachers, but also by nonspecializing institutions including teachereducation programs and graduate schools of education. Diversity in the institutions of teacher preparation implies diversity in the educational curricula of teacher preparation.

However, the differences that exist among different universities give rise to differences in the quality of the teachers they produce. In fact, differences in the training process among different institutions are substantial, and it is very difficult to seek adjustment of, and control over, those differences.

Whereas universities of education that prepare elementary school teachers retain relative uniformity compared to the institutions that prepare secondary school teachers, there exist rather significant differences in the educational curriculum among different universities. Universities of education offer four-year programs like general universities, and total credit hours required for graduation normally is 140 145, albeit with small differences among different universities of education. However, curricular variance is more pronounced among different universities of education: the period of practicum ranges from six to nine weeks, with three to five credit hours assigned to that work; 15 to 30 credit hours given to intensive course; 43 to 63 credit hours to courses dealing with subject matters (see Table 4).

Differences also are apparent in the ratio between required courses and electives. Credit hours allocated to pedagogical studies vary among different institutions, such as six to 14 credit hours when they are required and four to 12 credit hours when they are electives. Subjectmatter education exhibits equal variance in allocated credit hours among different institutions - 43 to 63 when it is required and zero to eight when it is an elective. In addition, courses in general education, arts, and physical education also show high variance.

Hence, even among the universities of education, which are considered to have stronger uniformity than the training institutions of secondary-school teachers, there exist big differences in the credit hours to be completed for each domain and in the ratio between the required and elective courses. At the same time, variances among universities are high in the hours allocated to intensive courses, practicum, and subject matter education.

Among teachers colleges, curriculum is supervised by each individual institution, resulting in diversity of curriculum among different colleges. And in the cases of the teacher-education programs in general universities and graduate schools of education, the curriculum is guided by the Enforcement Regulation Number 12 of the Teacher Certification Authorization Act, which specifies a certain number of subject matter and pedagogy courses.

Teachers colleges offer a four-year programs like general universities and the total credit hours required to acquire teaching certificate is normally 140 , including over 40 credit hours of subject matter courses and over 20 credit hours of general pedagogy courses, with small 


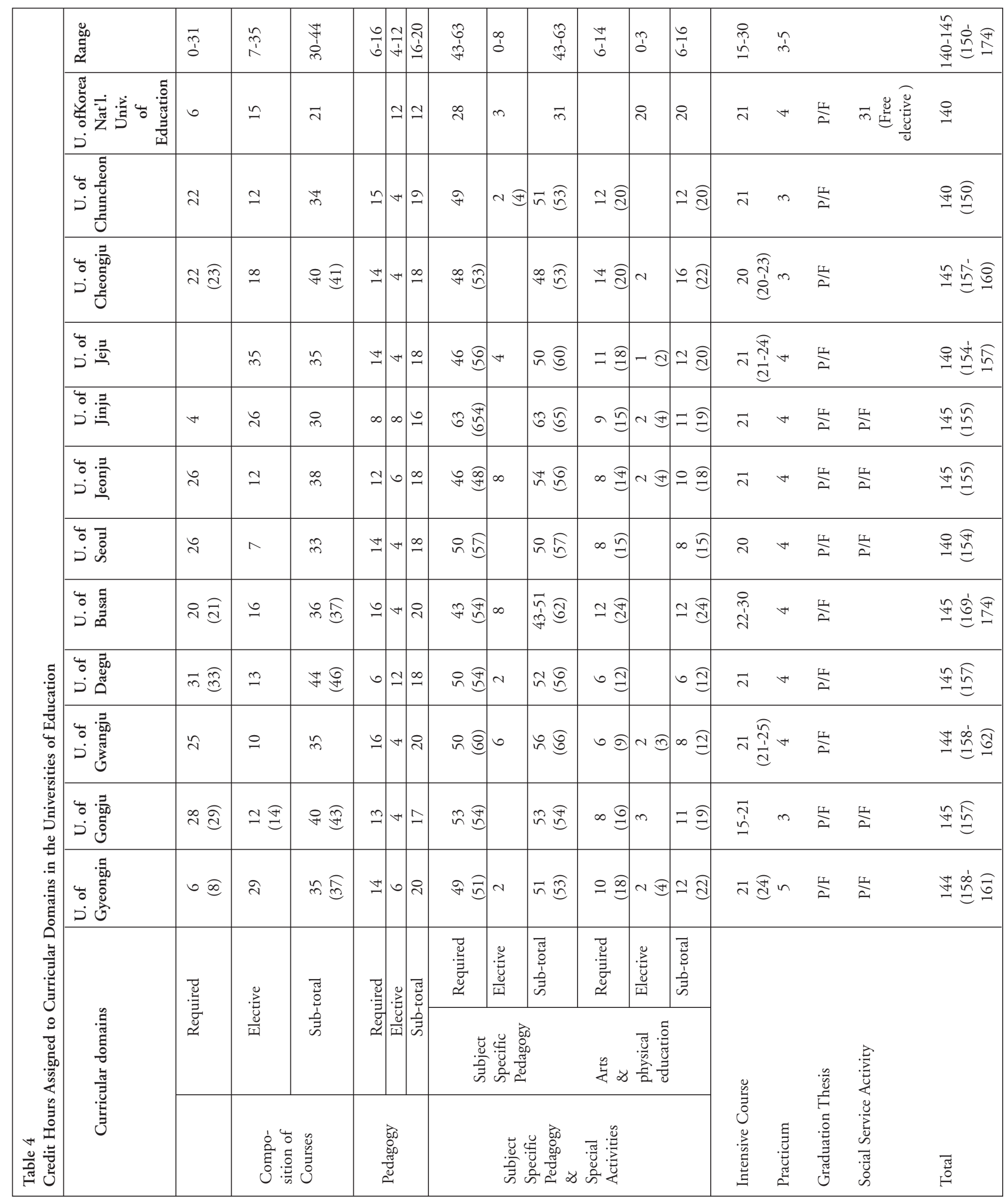


differences among colleges. In the case of the teacher education program of general universities, students are required to take over 42 credit hours of subject matter and over 20 credit hours of pedagogy courses, with the earned average point of at least 80 credit hours for both, to receive teaching certificate. In the case of graduate schools of education, students are required to take over 42 credit hours of major subject throughout their undergraduate and graduate periods and 20 credit hours of pedagogy courses.

In the preparation of secondaryschool teachers, the differences among teachers colleges, teachertraining programs in general universities, and graduate schools of education are great. Particularly, it is problematic, critics argue, that the teacher training programs of both general universities and graduate schools of education produce secondary-school teachers mechanically, simply by meeting the minimum standards specified by the Teacher Certification Authorization Act.

Curricular variance among different colleges of education is visible: in the case of the total credit hours for graduation, about $60 \%$ of the teachers colleges require 140 credit hours, $30 \%$ require 150 credit hours, and the rest require below 140 credit hours down to 130 .

Differences among colleges in curricular organization also are evident: 6 to 60 credit hours of general education, 52 to 120 credit hours of subject matter, 6 to 21 credit hours of general pedagogy, and 42 to 108 credit hours of subjectspecific pedagogy and subject matter. Also, the proportion of subject matter is 38 to $80 \%$, that of general pedagogy, 10 to $23 \%$, and the proportion of subject-specific pedagogy within subject matter is 10 to $51 \%$; hence, variance among colleges is clear.

Practice teaching is a very important curricular part of the teacher-preparation process. However, it is difficult to seek to strengthen practice teaching when there is a such an oversupply of teachers to be found at the secondary level. It is impractical to impart intensive practice teaching to the students, when only one in five eventually will enter the profession, making the practice-teaching experience a waste of time and money for the remaining four students.

Universities of education, which prepare elementary school teachers, run practice-teaching programs that are more diverse and systematic than those of the secondary-teachereducation institutions. Elementary teachers participate in practice teaching programs that are offered repetitively over several academic years. They include diverse activities such as observation, participation, classroom teaching, practical managerial work, and so on.

Duration of practice teaching ranges from six to nine weeks with three to five credit hours issued, depending on university. Both types and hours of practice teaching of major universities of education are presented in the Table 5 below.

Under current circumstances in which new teachers are required to teach in the classroom immediately upon their employment without an induction period, the minimum amount of practice teaching offered cannot guarantee that the prospective teachers receive sufficient training to face the reality of classroom teaching. Therefore, it is necessary to strengthen the management of practice teaching by lengthening its period, diversifying its types, and making it educationally meaningful.

Calls for improvement of the curricula of teacher preparation can be narrowed down to the following two problems: first, the problem of lack of quality control among different institutions; and second, the problem inherent in practice teaching. There should be a minimum level of standardization to help maintain uniformity among various curricula of the different teacher-training institutions, on the one hand, and to strengthen their professional content, on the other. Such inter-institutional standardization could ensure that first, a trainee can build his or her basic capacity to be an effective teacher, regardless of the location and type of the institution he or she enters, and second, qualitative equalization of the teachers produced by different institutions can be achieved to a desirable degree. Also, there should be efforts to strengthen practice teaching, including diversification of the period of practice teaching, lengthening its duration, and adoption of a probationary period.

To resolve these problems, the Korean government has pursued the following measures: revising the curricula of teacher preparation institutions; adopting an accreditation system of teacher preparation institutions; improving teacher preparation institution to the level equivalent to graduate school; abolishing the teacher-preparation function of graduate schools of education; and integrating the departments of teachers colleges. 
Table 5

Types and Required Credit Hours of Practice Teaching, University of Education

\begin{tabular}{|c|c|c|c|c|c|c|c|c|c|c|c|}
\hline \multirow[b]{2}{*}{ Univ. } & \multirow{2}{*}{$\begin{array}{l}\text { Types of Practice } \\
\text { Teaching }\end{array}$} & \multirow[t]{2}{*}{ Hours } & \multicolumn{2}{|c|}{ Freshman } & \multicolumn{2}{|c|}{ Sophomore } & \multicolumn{2}{|c|}{ Junior } & \multicolumn{2}{|c|}{ Senior } & \multirow{2}{*}{$\begin{array}{c}\text { Total } \\
\text { Duration }\end{array}$} \\
\hline & & & 1 & 2 & 3 & 4 & 5 & 6 & 7 & 8 & \\
\hline $\begin{array}{l}\text { Seoul } \\
\text { Nat'l. } \\
\text { Univ. of } \\
\text { Education }\end{array}$ & $\begin{array}{l}\text { Observation } \\
\text { Participation } \\
\text { Classroom Teaching } \\
\text { Practical Works }\end{array}$ & $\begin{array}{c}\text { non-credit } \\
1 \\
2 \\
1\end{array}$ & & & 1 week & 2 weeks & 2 weeks & 2 weeks & 2 weeks & & $\begin{array}{c}4 \\
\text { (9 weeks) }\end{array}$ \\
\hline $\begin{array}{l}\text { Gyeongin } \\
\text { Nat'l. } \\
\text { Univ. of } \\
\text { Education }\end{array}$ & $\begin{array}{l}\text { Observation } \\
\text { Subject Matter } \\
\text { Practical Works }\end{array}$ & $\begin{array}{l}1 \\
1 \\
3\end{array}$ & & & 2 weeks & & 1 & & 6 weeks & & $\begin{array}{c}5 \\
\text { (8 weeks) }\end{array}$ \\
\hline $\begin{array}{l}\text { Chuncheon } \\
\text { Nat'l. } \\
\text { Univ. of } \\
\text { Education }\end{array}$ & $\begin{array}{l}\text { Observation } \\
\text { Practical Works } \\
\text { Classroom Teaching }\end{array}$ & $\begin{array}{c}\text { no-credit } \\
1 \\
2\end{array}$ & & & & 1 week & & 2 weeks & 4 weeks & & $\begin{array}{c}3 \\
\text { (7 weeks) }\end{array}$ \\
\hline $\begin{array}{l}\text { Gwangju } \\
\text { Nat'l. } \\
\text { Univ. of } \\
\text { Education }\end{array}$ & $\begin{array}{l}\text { Observation } \\
\text { Classroom Teaching } \\
\text { \& Practical Works }\end{array}$ & $\begin{array}{c}\text { pass/fail } \\
4\end{array}$ & 1 week & & & & & & 8 weeks & & $\begin{array}{c}4 \\
\text { (9 weeks) }\end{array}$ \\
\hline $\begin{array}{l}\text { Busan } \\
\text { Nat'l. } \\
\text { Univ. of } \\
\text { Education }\end{array}$ & $\begin{array}{l}\text { Observation } \\
\text { Participation } \\
\text { Classroom Teaching } \\
\text { \& Practical Works }\end{array}$ & $\begin{array}{l}1 \\
1 \\
2\end{array}$ & & & & 1 week & & 2 weeks & 5 weeks & & $\begin{array}{c}4 \\
\text { (8 weeks) }\end{array}$ \\
\hline
\end{tabular}

\section{Teacher Certification System}

\section{Overview}

Prospective teachers who satisfactorily meet the graduation requirements specified by the Teacher Certification Authorization Act receive a teaching certificate. The teaching certificate is conferred by the Minister of Education through an authorization procedure without examination. It means that the certificates are conferred automatically upon graduation. They specify the school level for which the teacher is eligible to teach as well as major and minor subjects he or she is authorized to teach.

There is no age restriction for certificate acquisition. Teachers colleges, which prepare secondary school teachers, require their students to take a total of 140 credit hours including over 42 credit hours of major subject and over 20 credit hours of teacher training subjects, albeit with some differences among colleges. In the teacher education programs of general universities, students are required to take over 42 credit hours of major subject and over 20 credit hours of teacher training subjects, with the average GPA of at least B for both, to receive a teaching certificate. In the case of graduate schools of education, students are required to take over 42 credit hours in their major subject throughout their undergraduate and graduate periods and 20 hours of teacher training subjects.

Examinations are administered to those wish to become teachers to confer the preliminary teaching certificate when the problem of teacher undersupply occurs.

An identical teaching certificate is conferred at different types of teacher-training institutions, whether they be national/public or private. The certificate can be attained by completing the specified number of teacher training courses in nationally approved teacher training institutions. However, employment processes are different depending upon the types of schools. While the 
Table 6

The Summary of Teacher Certification System

\begin{tabular}{|c|c|c|}
\hline Type of Certificate & Grade 2 Teacher & Grade 1 Teacher \\
\hline $\begin{array}{l}\text { Certificate Acquisition } \\
\text { Method }\end{array}$ & Authorization without examination & Authorization without examination \\
\hline $\begin{array}{l}\text { Requirement for } \\
\text { Certificate Acquisition }\end{array}$ & $\begin{array}{l}\text { - Graduates of four-year training } \\
\text { institution } \\
\text { - Those who acquired master's degree } \\
\text { from graduate school of education }\end{array}$ & $\begin{array}{l}\text { - Certification standard and evaluation } \\
\text { result of in-service }\end{array}$ \\
\hline $\begin{array}{l}\text { Certificate Acquisition } \\
\text { Method and Procedure }\end{array}$ & $\begin{array}{l}\text { By submitting the non-examination } \\
\text { authorization application to the head of } \\
\text { university }\end{array}$ & $\begin{array}{l}\text { - Completing over } 15 \text { credit hours of } \\
\text { re-education courses administered by } \\
\text { in-service training institutions } \\
\text { designated by the regulations of the } \\
\text { Educational Civil Servant Law, with the } \\
\text { earned average point of } 60 \text { or higher } \\
\text { - Re-education is imparted to all } \\
\text { grade } 2 \text { teachers. }\end{array}$ \\
\hline Age Restriction & - & - \\
\hline $\begin{array}{l}\text { Relation to } \\
\text { Employment }\end{array}$ & $\begin{array}{l}\text { Open competition (age and qualifying } \\
\text { conditions) }\end{array}$ & Promotion based on qualifying process \\
\hline $\begin{array}{l}\text { Legal Base for } \\
\text { Certificate Acquisition }\end{array}$ & $\begin{array}{l}\text { Appendix } 2 \text { of the Item 2, Article No. 21, } \\
\text { Elementary and Secondary School } \\
\text { Education Law }\end{array}$ & $\begin{array}{l}\text { Article No. } 18 \& 21 \text {, Teacher } \\
\text { Certification Authorization Act }\end{array}$ \\
\hline Supervisory Body for Certification & $\begin{array}{l}\text { - Committee for Teacher } \\
\text { Certification Authorization is formed. } \\
\text { - Re-issuing of certificate follows the } \\
\text { pre-set regulation in the cases of } \\
\text { deprivation and loss of the certificate. }\end{array}$ & - \\
\hline
\end{tabular}

teachers of national and public schools are selected via an open, competitive employment test administered by each Metropolitan and Provincial Office of Education, private school teachers are employed via an independent selection procedure of each individual school, since the head of the private school reserves the right to employ teachers. Recently, however, in consideration of teacher professionalism, private schools have been advised by the government to hire their teachers through open competitive measures.

Higher level certificates in the profession are acquired based on the predetermined process and standards. The Grade 1 teaching certificate, a higher level certificate attainable after the Grade 2 certificate is conferred, can be acquired by completing over 15 credit hours of in-service education courses administered by in-service training institutions designated by the regulations of the Educational Civil Servant Law. The training for the Grade 1 teacher certification is imparted to all grade 2 teachers who have over three years of teaching experience. On average, it takes five to six years for a teacher to acquire the Grade 1 teaching certificate after his or her entry into the teaching profession. Table 6 sums up the certification system for the Grades 2 and 1 teaching certificates.

In Korea, a teaching certificate is a national certificate, which means that the national government recognizes that the certificate holder has acquired the knowledge and skills needed to perform the duties of teaching. For the national government to recognize the certificate holder's professional quality with certainty, it is necessary to control the quality of certificate acquisition process, and after the certificate is conferred, to supervise in a way that ensures continued professional development. However, under the current system of teacher certification of Korea, prospective teachers who lack the ability and aptitude to be teachers can enter teaching profession. Entering a 
Table 7

Teachers' Academic Qualification, by Location, School Level, and School Type, 2005

\begin{tabular}{|l|l|c|c|c|c|}
\hline \multicolumn{2}{|l|}{ Classification } & $\begin{array}{c}\text { Total No. } \\
\text { of Teachers }\end{array}$ & $\begin{array}{c}\text { No. of Teachers } \\
\text { with Academic } \\
\text { Qualification } \\
\text { below Four-Year } \\
\text { University }\end{array}$ & $\begin{array}{c}\text { No. of Teachers } \\
\text { with Bachelor's } \\
\text { Degree }\end{array}$ & $\begin{array}{c}\text { No. of Teachers } \\
\text { with Master's Degree } \\
\text { (or higher) }\end{array}$ \\
\hline Location & Metropolis & $166,120(100)$ & $8,157(5)$ & $117,741(71)$ & $40,222(24)$ \\
School Level & S\&M City & $209,117(100)$ & $16,184(8)$ & $145,118(69)$ & $47,815(23)$ \\
School Type & Elementary & $157,407(100)$ & $22,513(14)$ & $109,921(70)$ & $24,973(16)$ \\
& Secondary & $217,830(100)$ & $1828(0.5)$ & $152,938(70)$ & $63,064(29)$ \\
& Nat'l./Public & $298,436(100)$ & $23,442(8)$ & $207,563(69)$ & $67,431(23)$ \\
\hline Total & Private & $76,801(100)$ & $899(1)$ & $55,296(72)$ & $20,606(27)$ \\
\hline
\end{tabular}

${ }^{4}$ Data from KEDI and MOEHRD (2005). Annual Report on Educational Statistics. Seoul: Korean Educational Development Institute.

teacher- training institution is rather difficult compared with graduation. Researchers argue that the absence of national-level standards to manage the overall quality of certificate has contributed to the current problem. The existing practice certainly lowers public trust of the teaching certificate (Kim, Ee-gyeong, et al., 2004). To resolve such problems, many observers agree that it would be necessary to change the way the teaching certificate is acquired and to toughen the acquisition criteria. It also has been advocated that a national certification system be adopted. Policy studies are underway to identify the performance standards of different types of teachers to come up with national level standards.

There is another problem that surfaces after the teaching certificate is acquired: the fact that there is no expiration date of the certificate implies that once a person acquires the certificate, he or she need not seek further professional development. To counter this problem, it has been advanced that teachers be required to take part in periodic in-service training to renew their certificate for the purposes of enhancing public trust of the teaching certificate and improving teacher professionalism. Researchers propose the adoption of a certification renewal system that would validate the teaching certificate periodically.

\section{Data on Teachers' Qualifications}

Teaching certificates are conferred basically to those who graduate from four-year teacher-training institutions and those who acquire master's degrees from graduate schools of education; the proportion of the former is much higher among the entire pool of certificate holders. According to statistical data, as of 2005 , about $70 \%$ of elementary school teachers had a bachelor's degree, while about 23\% had a master's degree. Those pool of those who graduated from institutions less than a four-year university dates from the 1970s, when the universities of education offered only two-year programs; hence, about $93 \%$ of those whose academic qualifications do not include a bachelor's degree are elementary school teachers (see Table 7).

The percentage of certificate holders whose academic qualifications are at least a master's degree is higher in metropolitan areas than in small and medium-size cities, in private schools than in national/public schools, and in secondary schools than in elementary schools. Sixteen percent of teachers in elementary schools hold a master's degree, compared with $28 \%$ at secondary school level. The percentage of the certificate holders among the entire teachers was over $99 \%$ in 2005 (see Table 8).

\section{Out-of-Field Teaching}

Even an excellent system of training and certification of teachers that produces high-quality teachers does not guarantee optimal placement in teaching posts, thereby heightening the quality of classroom teaching. Even an excellent teacher is likely to provide low-quality instruction when he or she is assigned to the subject about which he or she is not knowledgeable. The problem of out-of-field teaching, one of the most direct causes of lowering of instructional quality, is closely related to assignment of teachers. Out-of-field teachers refer to those who teach subjects for which they have not attained specialized knowledge during their undergraduate or graduate school period. 
Table 8

Teaching Certificate Holders, $2005^{5}$

\begin{tabular}{|c|c|c|c|c|c|c|}
\hline \multirow{2}{*}{\multicolumn{2}{|c|}{ Category }} & \multicolumn{4}{|c|}{ Number of regular teachers } & \multirow[b]{2}{*}{ Unqualified } \\
\hline & & Sub-total & Teacher & Prelim. teacher & Others & \\
\hline Location & $\begin{array}{l}\text { Metropolis } \\
\text { S\&M City }\end{array}$ & $\begin{array}{l}166,120(100) \\
209,117(100)\end{array}$ & $\begin{array}{l}166,039(99.95) \\
208,908(99,90)\end{array}$ & $\begin{array}{c}41(0.02) \\
164(0.08)\end{array}$ & $\begin{array}{l}40(0.02) \\
45(0.02)\end{array}$ & None \\
\hline School level & $\begin{array}{l}\text { Elementary } \\
\text { Secondary }\end{array}$ & $\begin{array}{l}157,407(100) \\
217,830(100)\end{array}$ & $\begin{array}{l}157,248(99.90) \\
217,699(99.94)\end{array}$ & $\begin{array}{c}126(0.08) \\
79(0.04)\end{array}$ & $\begin{array}{l}33(0.02) \\
52(0.02)\end{array}$ & None \\
\hline School type & $\begin{array}{l}\text { Nat'l./public } \\
\text { Private }\end{array}$ & $\begin{array}{c}298,436(100) \\
76,801(100)\end{array}$ & $\begin{array}{c}298,216(99.93) \\
76,731(99.91)\end{array}$ & $\begin{array}{c}168(0.06) \\
37(0.05)\end{array}$ & $\begin{array}{l}52(0.02) \\
33(0.04)\end{array}$ & None \\
\hline Total & & $375,237(100 \%)$ & $374,947(99.92 \%)$ & $205(0.05 \%)$ & $85(0.02 \%)$ & None \\
\hline
\end{tabular}

${ }^{5}$ Date from KEDI and MOEHRD (2005). Annual Report on Educational Statistics. Seoul: Educational Development Institute.

In Korea, the Elementary and Secondary School Education Law provides guidelines for determining the number of teachers assigned to each school. The number of classrooms, which usually reflects the size of a school, becomes the yardstick for determining the number of teachers assigned to each school. According to the law, in the case of middle school, three teachers are to be assigned to a school with up to three classrooms, and if there are more than three classrooms in a school, 1.5 more teachers are added per additional class (Article Number 34). In the case of high school, three teachers are to be assigned to a school up to three classes, the same numbers as middle school, while two teachers are added with one additional class increase (Article Number 35). The number of students as well as teachers' teaching loads are not considered in determining the number of teachers supplied to each school. This formulation tends to increase teacher and becomes the cause of out-of-field teaching in small-sized schools.

Although the superintendent of each intermediate-level office of education is responsible for supplying appropriate numbers of teachers to schools according to the law, it is sometimes not properly observed, so that small-sized schools with small number of classes cannot have all the teachers needed for all subject matters. Under such a circumstance, to supplement the insufficient unit hours for instruction of different subjects and for the sake of administrative convenience, out-offield teaching takes place. Out-offield teachers cannot guarantee the quality of instruction, irrespective of their academic qualifications.

In Korea, a teacher's major and minor subjects are specified on the teaching certificate, which is conferred to teachers upon completing authorized teachereducation programs. Recently, the Korean government adopted a system recognizing a "minor qualification" acquired through in-service training in order to enhance the flexibility of the teacher supply. This qualification is given to certified teachers who cannot otherwise be assigned to schools because the subject matters specified in their teaching certificate as a major or minor are no longer offered at a school due to unpopularity.

For example, French and German language courses were offered at the upper-secondary level until 1980s.
However, the preference of students and schools for Japanese or Chinese over French or German has left many French or German teachers unassigned. Because public school teachers are national public servants and employment is guaranteed until the age of 62 , there should be remedial measures to reassign these teachers. Granting a minor qualification through in-service training was initiated to address this problem.

To acquire the minor qualification, teachers go through short-term in-service training of 180 hours during vacation, and are permitted to teach new subjects for which they have prepared themselves. Through this in-service, a number of teachers have become qualified to teach subjects different from the major or minor specified in their teaching certificate. However, the short-term intensive training, which is offered during vacation (approximately for three months), can be a tremendous burden on the teacher, and further, the lack of indepth study is criticized for failing to help teachers acquire specialized knowledge and competency. Compared with the 20 credit hours required for acquiring a minor certificate at a university, the newly 
initiated in-service training is hardly sufficient to prepare teachers for classroom teaching.

In addition, the in-service training programs and methods are under severe criticism. The vacationtime courses consist of lectures mainly by professors and lecturers from teacher-training universities that are of limited effectiveness in helping teachers apply their newly obtained knowledge in the classroom setting. Due to the impractical nature of the training, teachers are forced to prepare for teaching though individual study of instructional material. As a result, the quality of classroom teaching suffers.

Nevertheless, teachers whose subject matter has turned out to be unpopular appear to have no other choice but to acquire the minor qualification through the training course. And when the number of the applicants seeking the training is greater than available seats, teachers with fewer years of service have to defer the training to the future.

We need to understand the phenomenon of out-of-field teaching more accurately to come up with effective policy alternatives. It is necessary to determine in what regions out-of-field teaching takes place most frequently and to what extent, and in which school level and subject matter it is concentrated. For the purpose of the investigation, a survey questionnaire was developed and conducted based on stratified sampling of 2,000 secondary-school teachers nationwide. The survey was administered from mid-November to early December, 2005. A total of 1,423 teachers returned the questionnaire marking $71.2 \%$ response rate.

The data in Tables 9, 10, 11, 12 and 13 show five different measures of out-of-field teaching. Tables 9, 10 and 11 are prepared based on

\begin{tabular}{|c|c|c|c|c|c|}
\hline \multicolumn{6}{|l|}{$\begin{array}{l}\text { Table } 9 \\
\text { PERCEN }\end{array}$} \\
\hline & Korean & English & Math & Science & $\begin{array}{c}\text { Social } \\
\text { Studies }\end{array}$ \\
\hline Total & 3.64 & 8.70 & 11.03 & 24.81 & 5.14 \\
\hline \multicolumn{6}{|l|}{ Type of School } \\
\hline National \& Public & 4.48 & 10.00 & 11.04 & 27.27 & 5.23 \\
\hline Private & 1.98 & 6.45 & 11.01 & 20.29 & 5.00 \\
\hline \multicolumn{6}{|l|}{ Degree of Wealth } \\
\hline Rich & 7.41 & 1.61 & 6.56 & 24.64 & 0.00 \\
\hline Poor & 2.93 & 10.99 & 12.95 & 24.12 & 6.11 \\
\hline \multicolumn{6}{|l|}{ Community Type } \\
\hline Large Cities & 3.57 & 6.67 & 11.59 & 27.47 & 4.44 \\
\hline Medium and Small Cities & 4.04 & 6.33 & 12.20 & 21.60 & 5.43 \\
\hline Rural & 3.17 & 16.67 & 6.98 & 23.81 & 6.15 \\
\hline \multicolumn{6}{|l|}{ Grade Level } \\
\hline Lower Secondary & 4.47 & 12.17 & 10.26 & 32.47 & 8.04 \\
\hline Upper Secondary & 2.44 & 5.80 & 11.64 & 17.26 & 3.33 \\
\hline \multicolumn{6}{|l|}{ Number of Classes } \\
\hline $1-12$ & 6.06 & 17.24 & 12.00 & 24.53 & 7.14 \\
\hline $13-26$ & 5.26 & 11.84 & 9.33 & 19.53 & 4.62 \\
\hline $27-33$ & 2.25 & 4.69 & 8.00 & 35.87 & 3.30 \\
\hline $34-55$ & 2.35 & 5.95 & 14.77 & 22.03 & 6.38 \\
\hline \multicolumn{6}{|c|}{$\begin{array}{l}\text { arvey by author. } \\
\text { a. Private schools refer to schools whose ownership belongs to the private foundation. } \\
\text { b. Lower-secondary school level refers to those teaching grades } 7-9 \text { th, and upper- secondary level refers to grades } \\
10-12 \text { th. } \\
\text { c. Degree of wealth refers to the level of community wealth where the school is located. Since there was no accu- } \\
\text { rate data available regarding community wealth, it was drawn based on teachers' perception. } \\
\text { d. The number of classes refers to the total number of classes per school. It informs the size of schools. }\end{array}$} \\
\hline
\end{tabular}

teaching certificates, while Table 12 and 13 are based on undergraduate or graduate majors/minors.

Table 9 shows the percentage of secondary teachers who teach subjects other than the one specified as the major on his or her teaching certificate. Table 10 shows the percentage of teachers who teach subjects other than the one specified as major or minor on his or her teaching certificate, while Table 11 shows the percentage of teachers who teach subjects other than the one specified as major, minor, or minor acquired through in-service training.

Among Tables 9, 10 and 11, Table 9 applies the toughest standard requiring a teaching certificate with a specific major on it. The comparison between Tables 10 and 11 shows that a small portion of teachers are qualified to teach core subjects through in-service training. Shown in Table 11, Korean, English and social studies do not reveal serious problems, as the percentage of teachers who teach those subjects without a certificate in the field is relatively low. However, about $11 \%$ of math teachers and $25 \%$ of science teachers teach a subject without a proper in-field certificate.

In general, as the definition of out-of-field teachers becomes tougher, the percentage of out-offield teachers becomes higher. As Tables 12 and 13 show, the percentage of out-of-field teachers who are defined as such based on undergraduate or graduate major/minor is much lower than that based on teaching certificate. When the undergraduate or graduate major/minor definition is applied, the percentage of out-of-field 


\begin{tabular}{|c|c|c|c|c|c|}
\hline \multicolumn{6}{|c|}{$\begin{array}{l}\text { Table } 10 \\
\text { PERCENTAGE of Secondary Teachers in Korea in the Core Academic Fields Without } \\
\text { a Teaching Certificate (Major or Minor) in the Field by Type of School, 2005. }\end{array}$} \\
\hline & Korean & English & Math & Science & $\begin{array}{l}\text { Social } \\
\text { Studies }\end{array}$ \\
\hline Total & 1.99 & 3.95 & 10.65 & 24.81 & 3.08 \\
\hline \multicolumn{6}{|l|}{ Type of School } \\
\hline National \& Public & 1.99 & 3.75 & 10.39 & 27.27 & 3.49 \\
\hline Private & 1.98 & 4.30 & 11.01 & 20.29 & 2.50 \\
\hline \multicolumn{6}{|l|}{ Degree of Wealth } \\
\hline Rich & 1.85 & 1.61 & 6.56 & 24.64 & 0.00 \\
\hline Poor & 2.09 & 4.95 & 12.44 & 24.12 & 3.49 \\
\hline \multicolumn{6}{|l|}{ Community Type } \\
\hline Large Cities & 1.43 & 3.33 & 11.59 & 27.47 & 2.96 \\
\hline Medium and Small Cities & 2.02 & 2.53 & 10.98 & 21.60 & 1.09 \\
\hline Rural & 3.17 & 7.41 & 6.98 & 23.81 & 6.15 \\
\hline \multicolumn{6}{|l|}{ Grade Level } \\
\hline Lower Secondary & 2.79 & 4.35 & 9.40 & 32.47 & 3.57 \\
\hline Upper Secondary & 0.81 & 3.62 & 11.64 & 17.26 & 2.78 \\
\hline \multicolumn{6}{|l|}{ Number of Classes } \\
\hline $1-12$ & 6.06 & 6.90 & 12.00 & 24.53 & 7.14 \\
\hline $13-26$ & 3.16 & 5.26 & 9.33 & 19.53 & 3.08 \\
\hline $27-33$ & 1.12 & 1.56 & 8.00 & 35.87 & 0.00 \\
\hline $34-55$ & 0.00 & 3.57 & 13.64 & 22.03 & 4.26 \\
\hline
\end{tabular}

${ }^{7}$ Survey by author.

Table 11

PERCENTAGE of Secondary Teachers in Korea in the Core Academic Fields Without a Teaching Certificate (Major, Minor or Minor Acquired through Inservice Training) in the Field by Type of School, 2005. ${ }^{8}$

\begin{tabular}{|c|c|c|c|c|c|}
\hline & Korean & English & Math & Science & $\begin{array}{l}\text { Social } \\
\text { Studies }\end{array}$ \\
\hline Total & 1.66 & 2.77 & 10.27 & 22.76 & 2.40 \\
\hline \multicolumn{6}{|l|}{ Type of School } \\
\hline National \& Public & 1.99 & 3.13 & 9.74 & 25.30 & 2.91 \\
\hline Private & 0.99 & 2.15 & 11.01 & 18.12 & 1.67 \\
\hline \multicolumn{6}{|l|}{ Degree of Wealth } \\
\hline Rich & 1.85 & 1.61 & 6.56 & 23.19 & 0.00 \\
\hline Poor & 1.67 & 3.30 & 11.92 & 22.51 & 2.62 \\
\hline \multicolumn{6}{|l|}{ Community Type } \\
\hline Large Cities & 1.43 & 2.50 & 11.59 & 26.37 & 2.22 \\
\hline Medium and Small Cities & 2.02 & 2.53 & 9.76 & 18.40 & 1.09 \\
\hline Rural & 1.59 & 3.70 & 6.98 & 21.43 & 4.62 \\
\hline \multicolumn{6}{|l|}{ Grade Level } \\
\hline Lower Secondary & 2.23 & 3.48 & 8.55 & 29.90 & 2.68 \\
\hline Upper Secondary & 0.81 & 2.17 & 11.64 & 15.74 & 2.22 \\
\hline \multicolumn{6}{|l|}{ Number of Classes } \\
\hline $1-12$ & 3.03 & 3.45 & 12.00 & 22.64 & 4.76 \\
\hline $13-26$ & 3.16 & 3.95 & 9.33 & 17.97 & 3.08 \\
\hline $27-33$ & 1.12 & 1.56 & 8.00 & 34.78 & 0.00 \\
\hline $34-55$ & 0.00 & 2.38 & 12.50 & 18.64 & 3.19 \\
\hline
\end{tabular}

${ }^{8}$ Survey by author. teachers in most subjects drops significantly, though the percentage of out-of-field science teachers is still high enough to cause serious concerns.

Considering the fact that there is an oversupply of secondary teachers and almost $100 \%$ of secondary teachers hold teaching certificates, the data concerning out-of-field teachers raise the problem of quality of teaching caused by mismatch between professional expertise and teaching subjects.

There also are large cross-school differences in out-of-field teaching. In most fields, teachers in national or public schools are more likely to be assigned to teach out of their field than are those in private schools. For example, according to Table 11, 25\% of teachers teaching science classes in public schools are out of field, compared with $18 \%$ of those in private schools. In four of the five academic fields, there is higher percentage of out-of-field teachers in national or public schools than in private schools.

Teachers at schools located in relatively poor communities are more likely to be assigned to out-of-field classes-a tendency observed in four of the five subject areas. Korean is the only subject showing a different tendency. Rural and remote areas are characterized as much less affluent and providing fewer opportunities than urban areas. This causes the problem young people abandoning their hometown to look for better educational or economic opportunities. Korea is facing a continuing population decrease in rural areas due to economic, cultural, and educational deprivation in the agricultural and fishing regions. The effect is a continuous decrease in the student population of rural areas and smaller schools in those areas.

A logistical problem results. It is 


$\begin{aligned} & \text { Table 12 } \\ & \text { PERCENTAGE of Secondary Teachers in Korea in the Core Academic Fields }\end{aligned}$
an Undergraduate or Graduate Major in the Field by
anpe of School, 2005.

not possible to place as many teachers in small schools as would be needed to cover every academic subject. If they were placed, they would not be able to fulfill their required hours of teaching. Hence, the easiest solution to the problem is out-of-field teaching. The size of schools expressed by the number of classes per schools is closely related to the percentage of out-of-field teachers as shown in Table 12.

Multiple-grade teaching, in which students of different grades gather in a single classroom to receive instruction, often is utilized to solve the problem. That scenario, however, places a burden on teachers and represents an obstacle to instructional effectiveness.

While out-of-field teaching is most pronounced in small schools, metropolitan areas are not immune from it either. Teachers of unpopular subjects get out-of-field assignments to fill up their work day.

More out-of-field teaching occurs at the lower-secondary level than upper- secondary. According to Table 13 , lower-secondary teachers are more likely to be assigned to out-offield classes. It is obvious in four of the five core subjects, except math. Science seems to be the most serious case. Approximately 30\% of lowersecondary teachers teaching science are out-of-field, while there are 16\% at the upper-secondary level. Teachers tend to be considered subject-matter specialists in the upper grade levels, because more rigorous and sophisticated knowledge and competencies are required. It is rather easier for teachers to teach lowersecondary classes than uppersecondary classes.

Out-of-field teaching occurs because of inflexibility in supply and demand of teachers. Small schools in rural areas experience difficulties in securing teachers to teach all subject matters due to a shortage of students, so teachers in those schools often find themselves handling multiple subject matters beside the ones specified in their teaching certificates.
In such cases, teachers feel burdened by out-of-field classes and tend to harbor discontent about such practices, which leads to providing low-quality classroom instruction to students.

Another important reason why out-of-field teaching occurs can be found in the recent change in Korea's educational policy adopting a new national curriculum that emphasizes school autonomy and student choice. Some subjects have disappeared as 11 th and 12th graders have chosen not to enroll in some courses. Unpopular subjects include military training and foreign languages like French and German. Korean law secures the employment status of public school teachers, so they cannot be dismissed, even when their subjects are no longer taught.

The government's attempts to resolve the problem of out-of-field teaching, including having some teachers circulate to other schools, employment of part-time and contract teachers, and an industryschool co-teaching system, have not proven successful. For instance, the circulation plan calls on teachers who cannot fulfill their required teaching hours in their home school to teach in other schools, for bonus points, or a stipend. But that plan has not been welcomed by teachers because, first, they find it is burdensome to commute to several other schools, teach there, and adapt to unfamiliar school atmosphere; second, they are not exempt from administrative chores at their home school, though they work long hours elsewhere; and third, bonuses for such work are not given evenly across different metropolitan and provincial regions, so there are teachers who do not receive benefits for such a burdensome teaching assignment. The practice of out-of-field teaching seems an unavoidable choice. 


\begin{tabular}{|c|c|c|c|c|c|}
\hline & Korean & English & Math & Science & $\begin{array}{c}\text { Social } \\
\text { Studies }\end{array}$ \\
\hline Total & 1.99 & 0.79 & 1.52 & 25.32 & 1.71 \\
\hline \multicolumn{6}{|l|}{ Type of School } \\
\hline National \& Public & 2.49 & 0.63 & 1.95 & 24.90 & 1.74 \\
\hline Private & 0.99 & 1.08 & 0.92 & 26.09 & 1.67 \\
\hline \multicolumn{6}{|l|}{ Degree of Wealth } \\
\hline Rich & 1.85 & 0.00 & 0.00 & 24.64 & 0.00 \\
\hline Poor & 2.09 & 1.10 & 2.07 & 25.08 & 2.18 \\
\hline \multicolumn{6}{|l|}{ Community Type } \\
\hline Large Cities & 3.57 & 0.83 & 1.45 & 30.22 & 0.74 \\
\hline Medium and Small Cities & 0.00 & 0.00 & 2.44 & 20.00 & 1.09 \\
\hline Rural & 1.59 & 1.85 & 0.00 & 22.62 & 4.62 \\
\hline \multicolumn{6}{|l|}{ Grade Level } \\
\hline Lower Secondary & 3.35 & 0.87 & 1.71 & 32.47 & 2.68 \\
\hline Upper Secondary & 0.00 & 0.72 & 1.37 & 18.27 & 1.11 \\
\hline \multicolumn{6}{|l|}{ Number of Classes } \\
\hline $1-12$ & 3.03 & 0.00 & 0.00 & 24.53 & 4.76 \\
\hline $13-26$ & 2.11 & 1.32 & 0.00 & 21.88 & 1.54 \\
\hline $27-33$ & 2.25 & 0.00 & 1.33 & 36.96 & 0.00 \\
\hline $34-55$ & 1.18 & 1.19 & 3.41 & 20.34 & 2.13 \\
\hline
\end{tabular}

${ }^{10}$ Survey by author.

\section{Conclusions}

It is certain that measuring the quality of teaching force is quite complicated because many aspects are mingled together. Viewed from outside the system, the quantity and quality of teachers in Korea seems to be all right. The profession is favored by excellent students and there exists a plethora of teacher aspirants, so teacher-education institutions do not have to worry about attracting qualified students. Nearly $100 \%$ of prospective teachers acquire their teaching certificates before entering a school—an indication of a qualified teaching force.

However, it is not certain that the quality and qualifications of the Korean teaching force are good enough considering all the problems associated with teacher preparation and certification. It is not an exaggeration to say that teacher- and certification, but they have failed to produce visible outcomes. For instance, policy measures to undertake evaluations of education institutions and to either shut down those institutions of poor quality or to upgrade teacher-education institutions to the level of graduate schools were proposed several years ago, but have not been properly implemented; there is no prospect of their easy implementation in the foreseeable future, either. During the last three decades, education reform efforts pursued by the Korean government did not give enough attention to issues related to teacher quality.

Many people question the view that the teacher is a professional, on the grounds that the teaching profession does not seem to have a lot in common with other professions. This is a fundamental challenge facing Korea's education system today. To meet that challenge, it is necessary to come up with a systemic reform in which teacher professionalism is fully developed through the phases of initial education, certification, and assignment. At the secondary-school level, the oversupply of prospective teachers has been exaggerated over time, which undermined recognition of the problem of hidden shortages. In order to guarantee that each and every school is equipped with fully qualified teachers, more attention should be paid to the problem of out-of-field teaching. It is particularly important because education of good quality can never occur without teachers of good quality possessing appropriate skills and knowledge acquired through training in the areas they are supposed to teach. 


\section{References}

Hwang, G., et al. (1999). Measures to improve the teacher training and education system. Seoul: Korean Ministry of Education.

Kim, E. (2003). Policy research to analyze Korea's participation in the OECD Teacher Policy Review Project. Seoul: KEDI.

Kim, E., \& Han, Y. (2003). Attracting, developing and retaining effective teachers: A background report for Korea. Seoul: KEDI.

Kim, E., et al. (2004). Research on the measures to revise the teacher certification and training system. (Committee for Revising the Teacher Certification and Training System) Seoul: KEDI.

Kim, E., et al. (2006). The supply and demand of elementary and secondary teachers in the midst of change of school education. Seoul: KEDI.

Korean Educational Development Institute. (2004). Analytical data on the educational statistics. Seoul: KEDI.

Korean Educational Development Institute and Ministry of Education and Human Resources Development. (2005). Annual report on educational statistics. Seoul: KEDI.

Lee, J., et al. (2004). A study on the means to innovate teacher policy: Teacher personnel management system. CR 2004-25. Seoul: KEDI.
Ministry of Education and Human Resources Development. (2001). Comprehensive measures for the development of teaching profession to face the twenty-first century. Seoul: MOEHRD.

Park, A. (1997). The essence of general education in teacher training and the tasks for development, In Securing specialization in the teacher training curriculum. Collection of the papers for the conference of the Korean Society for the Study of Education.

Park, Y. (2005). Revision of the Teacher Certification System, In 2004 Discussion of Korea's education: Tasks of Korea's education seen through the perspective of educational competitiveness. Seoul: KEDI.

Santiago, P. (2003). Teacher demand and supply: Improving teaching quality and addressing teacher shortage. Paris: OECD. 


\section{CHAPTER 6 The Qualifications of the Teaching Force: Data From Singapore}

Steven K. S. Tan and Angela F. L. Wong with

S. Gopinathan, Kim Chuan Goh and Isabella Y. F. Wong

National Institute of Education

Nanyang Technological University

and

Kong Hong Ong

Ministry of Education

\section{Introduction}

Education has been both the key source of competitive strength and a necessity for the economic growth and social viability of Singapore as a nation since self-government in 1959. In a process of continual development and ongoing improvement, education policies and practices have been reviewed and refined through the years. Since the mid 1990s, the world has been constantly changing around us and this fact has challenged the Ministry of Education (MOE) to make fundamental paradigm shifts in the strategic direction of the education system so that it is geared to meet the needs of Singapore in the 21st century (Gopinathan, 1999; Sharpe \& Gopinathan, 2002).

First, globalization is rapidly recasting the economic landscape and redefining the international workplace in which nations have to operate. Second, technological change is proceeding at a rapid pace, resulting in changes in the ways individuals live and work. Third, intellectual capital increasingly will become the basis for competitive advantage among companies and nations. Therefore, education in Singapore must equip successive generations to thrive in an intensely competitive global marketplace, to imbue them with moral attitudes, enterprising and innovative mindsets, and to ensure they are technologically savvy, flexible and willing to continually learn and upgrade their skills. To succeed in this endeavor, Singapore will be dependent on a high-quality teaching workforce with the values, instincts, life skills and competencies on which we entrust them with the heavy responsibilities of molding the lives of our young people.

As in other Asian nations, teachers generally are well respected in Singapore society, and the Ministry of Education has been actively calling for the public and parents to give respect, appreciation, and regard to the profession (Goh \& Chang, 2002; Lee, 1996, 2006;

Shanmugaratnam, 2004, 2006a; Teo, 1998). The MOE also is cognizant of the important role teachers play in educating new generations to break new ground and chart new directions for Singapore. Since embarking on the "Thinking School, Learning Nation" vision in 1997 (Goh, 1997), the MOE has regarded teachers as central to this whole change process and as exemplary role models in seeking out new ideas, learning and practices, and continuously innovating and refreshing their own knowledge (Shanmugaratnam, 2004).

The MOE's goal of building up a qualified teaching force is achieved through a process of careful and detailed planning, aggressive teacher recruitment, comprehensive training and effective teacher retention. Quality is as important as numbers; nevertheless, numbers do count. With better recruitment comes the opportunity to make an investment in the future by adding more qualified teachers to every school. With more teachers per school, and coupled with better job prospects, retention rates of good-quality teachers also will improve.

The purpose of this paper is to describe the qualifications of the teaching force in Singapore. The paper will first provide a brief summary of the Singapore education system with a focus primarily on primary and secondary education. The next section will introduce qualification standards and 
preparation requirements for becoming a teacher. Specifically, it will address the levels of qualification of the current teaching force, both at the recruitment and certification stages. Finally, the paper will address teacher qualifications for teaching different subjects in secondary schools and how the education system as a whole manages the issues of underqualified teachers and outof-field teaching.

\section{Overview of the Singapore Education System}

The mission of education is Singapore is to "mould the future of the nation" - that is, to shape the learning of young people who will determine the future of the nation. As a system, the key advantage of Singapore education is that it is well structured and efficient in providing educational pathways and differently paced curricula to cater to the different needs, capabilities, aptitudes and learning modalities of students. To do so, the system identifies as early as possible the different abilities and interests of students and then "mass customizes" flexible educational programs to cater to the varying requirements of each group of students. Singapore's education system therefore is geared towards a broad-based holistic education allowing students to draw from a diversity of knowledge, learning experiences and opportunities so that they can pursue their passions and develop special talents. The goal also is to nurture and prepare Singaporeans to go forward with a strong social conscience and mindset so that they will be ready to compete in the highly innovational, highly entrepreneurial economy of the future (Chen, 2000; Lee, 2006; MOE, 1999; Shanmugaratnam,
2003, 2004, 2006b; Teo, 1999, 2001).

Every child in Singapore undergoes at least 10 years of general education, comprising six years of primary (elementary) education and four years of secondary (high school) education (see Figure 1). The different educational courses available to pupils in post-secondary education will not be discussed in this paper.

\section{Primary Education}

At the primary level, pupils go through two stages: (a) a four-year foundation stage, from primary one to four (grades 1 - 4); and (b) a twoyear orientation stage from primary five to six (grades 5 and 6). The emphasis during the foundation stage is on basic literacy in English and their mother tongue (i.e., Chinese, Malay and Tamil languages) and mathematics. Arts and crafts, health and physical education, moral education, music, science and social studies are included in the curriculum to ensure that students have a good grounding across different areas of study. Furthermore, primary education seeks to provide students with sound values and life skills, and to develop students' thinking and communication skills.

\section{Secondary Education}

At the end of primary six, pupils take the Primary School Leaving Examination (PSLE). According to learning pace, aptitude and inclination, pupils are placed in one of three secondary-school streams: Special, Express, or Normal. These courses provide pupils with different curricular emphases that match their abilities and interests. The majority (approximately 61\%) of pupils takes the Special or Express courses, while the remaining 39\% enter the Normal course stream (see Statistics for Secondary Enrollment by age, level, stream, Planning Division, Ministry of Education, 2006).

The Special and Express stream pupils are of higher ability and study the same curriculum except that the Special stream pupils learn their mother tongue as a first language while their Express counterparts are taught it at a second language level. These pupils complete their secondary education in four years by sitting for the Singapore-Cambridge General Certificate of Education Ordinary-Level Examination.

Within the Normal-course track, pupils have the option of taking either the Normal/academic or Normal/technical curriculum, both of which lead to the SingaporeCambridge General Certificate of Education Normal Examination at the end of four years. Those who are competent can proceed onto a fifth year of study where they sit for the Singapore-Cambridge General Certificate of Education OrdinaryLevel Examination similar to those pupils from the Special and Express courses.

\section{Teacher Preparation, Requirements and Standards}

The importance given to teachers and the teaching profession in Singapore has enabled the nation to maintain a dynamic education system capable of delivering quality education to meet changing needs and demands for more than four decades. It is therefore crucial for us to be able to attract and retain the people we need to educate our young. To this end, all the interrelated processes pertaining to recruitment, training, certification, appointment, and deployment of teachers for the Singapore schools are the sole responsibility of the Ministry of Education. This is not done in 
Figure 1

Structure of Schooling in Singapore by Education Level, Typical Age and Years of Schooling, 2006.

\section{THE SINGAPORE EDUCATION LANDSCAPE}

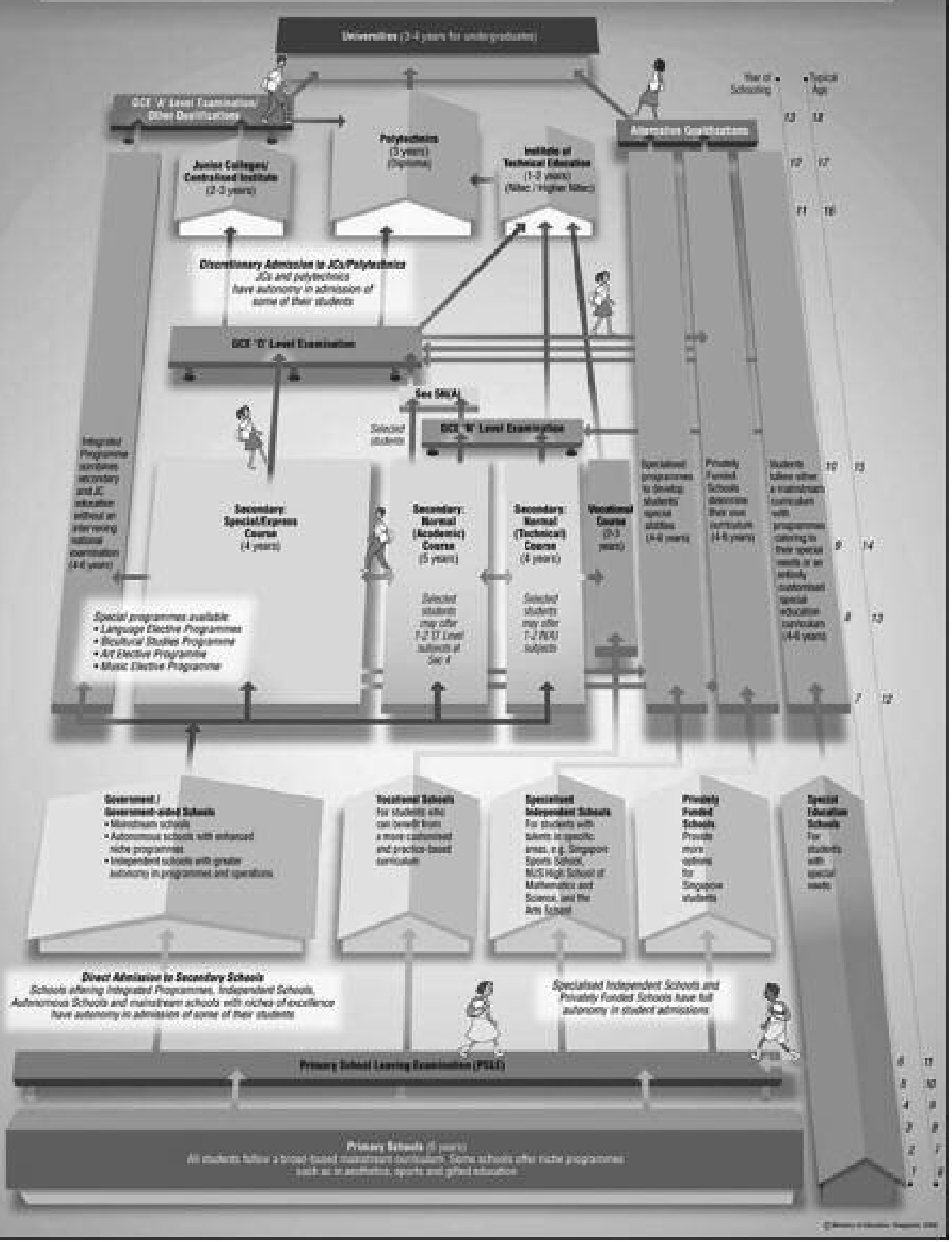

'Education Statistics Digest 2006, Planning Division, Ministry of Education, 2006 
isolation, but in constant

consultation with schools, the

National Institute of Education

(NIE) (see below for elaboration on

the role of NIE in teacher training),

and other stakeholders-for example,

teachers, parents, other government

ministries, universities, and

businesses. This is particularly

important as Singapore seeks to

maintain a high level of qualifications

among the teachers beyond those

related to licensing standards that is

common to many countries.

A structure that is basically

"closed" enables Singapore to manage its teaching workforce both in terms of quantity and quality, and to carefully monitor issues. Such a centrally managed system helps Singapore prevent wastage in human resources and minimize problems like teacher shortages and high turnover, underqualified teachers and out-offield teaching.

\section{Role of the Ministry of Education}

Responsibility for hiring teachers to meet the needs of the Singapore school system lies primarily with the Ministry of Education. The MOE uses feedback gathered annually from schools as well as its own data to plan for personnel needs and also attempts to do strategic forecasting to resolve both short-term needs (such as vacancies resulting from retirements and resignations) and long-term system requirements such as planning for new schools, initiatives and programs.

Since 2004, the profession has been attracting a steady flow of about 1,900 teachers per year, and will continue to recruit close to that number every year over the next five years (Shanmugaratnam, 2004). The Singapore teaching force stands at 28,500 today, up from 24,600 in 2001 , and is on track to reaching 30,000 by 2010 (Shanmugaratnam, 2006a). The MOE seeks to recruit teachers from the top one-third of each cohort of Singaporeans. This means the MOE attracts recruits from university-degree holders and those who have done well in the polytechnical schools. Besides meeting academic standards, aspiring teachers also must have aptitude and interest, as revealed in interviews with experienced principals and teachers (Teo, 2000). The next section will describe the academic qualifications required to become a teacher in detail.

\section{Academic Qualifications Required for Teaching}

Interested applicants are invited to attend "Teaching as a Career" recruitment seminars organized by the MOE and held regularly during the year. Individuals also can apply via the Internet on the MOE Website. Depending on an individual's academic qualifications, one can apply to become either a graduate or nongraduate teacher.

To be considered a graduate teacher, individuals must possess a university (bachelor, undergraduate or college) degree, including coursework in requisite teaching subjects. The section on "Secondary Grade Level Teachers' Subject Qualification and the Subject Taught in Schools" provides an indication of majors (subjects) individuals must have studied at the university level to be qualified to teach that subject(s) in schools.

The admission criteria for nongraduate teachers (i.e., those without any university degree) can include any one of the following academic qualifications: (a) the General Certificate of Education (GCE) 'Ordinary' level (Grade 10)²; (b) the General Certificate of Education (GCE) 'Advanced' level (Grade 12); or (c) a Polytechnic diploma.
Once individuals meet the academic qualifications, they are then shortlisted for the interview process, wherein each application is considered in competition with that of other applicants. The interviewers seek to learn more about the following qualities in an individual:

- passion for teaching

- ability to communicate well with others

- creative and innovative spirit

- confidence

- leadership qualities

- good role model

Recruitment, training and deployment of teachers in Singapore is quite unlike that in other nations. First, it is important to emphasize that individuals who are hired as trainee teachers are regarded as full civil-servant employees (called General Education Officers) ${ }^{3}$ of the ministry. Therefore, all trainee teachers are guaranteed teaching positions and are automatically deployed to schools upon completion of training at NIE (see below).

Second, as civil servants, all trainee teachers receive a full monthly salary, including Central Provident Fund $^{4}(\mathrm{CPF})$ contributions, year-end bonuses, NIE tuition grant, and other benefits due all civil service employees even when they are undergoing NIE training (see below). Depending on the individual's qualifications, pedagogical training, working experience and gender ${ }^{5}, \mathrm{a}$ teacher's starting salary ranges from $\$ 1,020$ to $\$ 2,060^{6}$ (U.S.) a month.

2 The General Certificate of Education or GCE is a secondary-level academic qualification, and is generally divided into two levels: Ordinary level (O-level) and Advanced level (A-level). Students in Singapore take the O-level examination at grade 10,
and the A-level examination is taken at grade 12.

3 General Education Officers (GEO) is the civil

service terminology for teachers.

4 The Central Provident Fund (CPF) is a

comprehensive social security savings plan for the Singapore workforce.

5 Male Singaporeans who have completed compulsory National Service will receive additional increments because of the time spent during the two years of military training.

61 US\$ = Singapore $\$ 1.60$. 
Third, all individuals hired but untrained will be sponsored to attend the NIE for their pedagogical training in the subject areas and grade levels that they have been hired for. Finally, because of this huge capital investment in them in terms of salaries and tuition grants, trainee teachers are required to serve a socalled teaching bond, ranging from three to four years, after they graduate from teacher training.

\section{Role of the National Institute of Education in Teacher Training}

The provision of teacher education in Singapore on a long-term and organized basis started with the establishment of the Teachers' Training College (TTC) in 1950, which conducted certificate courses in education for nongraduates. Graduate teachers were trained at the School of Education established in the same year at the then University of Malaya (later the University of Singapore). In 1973, the Institute of Education (IE) was established out of the TTC to train both graduate and nongraduate teachers on a full-time basis and including a part-time teaching cadetship scheme. In 1980, a full-time teacher-in-training scheme was implemented for all aspects of teacher training.

In 1991, the Institute of Education and the College of Physical Education (set up in July 1984 to train specialist teachers in physical education) were merged to form the present National Institute of Education as an autonomous institute of the Nanyang Technological University. Currently, NIE is the sole teacher-training institution in Singapore whose primary role is the training of all teachers for Singapore local schools. All successful individuals who are hired by the MOE and do not have the required pedagogical training are expected to enroll in NIE for one of the teacher-education programs.

Even though NIE is autonomous (with its own council and director), it shares a symbiotic relationship with the Ministry of Education. MOE hires the teachers, and NIE trains them. NIE works with MOE to define academic qualification standards for hiring different categories of teachers and provides input into the interview-selection process. NIE faculty are invited to be involved in the numerous MOE curriculum-review committees, and help make recommendations for any curriculum changes and initiatives. Such curricular changes are reflected in timely revisions to NIE's teacher preparation programs, so that teachers are current in their knowledge and qualified. This applies both to the training of new teachers and professional development for over 26,000 practicing teachers in the education system.

Due to this close relationship with the MOE, all teachers who have completed any one of the teachereducation programs offered by NIE automatically are certified to teach in the Singapore school system. NIE maintains the professional teaching standards that define what accomplished teachers should know and be able to do through its quality programs and stated outcomes. Therefore, individuals completing an NIE program do not have to take additional examinations and/or seek certification through a teaching standards board. Technically, MOE and NIE, in this interrelated system, act as the standards board.

\section{Programs Offered by NIE to Train Teachers \\ NIE offers three different initial teaching-preparation programs to help individuals obtain a teaching qualification (or certification) to}

enable him or her to teach in the Singapore school system. These programs are:

(a) Diploma in Education (Dip Ed)

(b) Postgraduate Diploma in Education (PGDE)

(c) Bachelor of Arts/Science (Education) (BA[Ed]/BSc[Ed])

The diploma program is a nondegree two-year program that leads to the awarding of a diploma in education and is specifically designed for nongraduate teachers. Generally, those trainee teachers with polytechnic diplomas or the GCE Alevel qualifications as well as those degree holders who do not meet the requirements for appointment as graduate teachers (a minority) will be sponsored for this program.

University graduates (i.e., degree holders without teaching qualifications) are sponsored for the one-year post-graduate Diploma in Education program ${ }^{7}$. This program is akin to the fifth-year program in some teacher-education programs in the United States where individuals have the opportunity to apply theory (preservice content area) to practice (internship, field experiences, or practicum) and obtain a teaching credential. However, these individuals in Singapore do not earn a master's degree in teaching.

The four-year degree program is open to all successful GCE A-level holders who qualify for university admission ${ }^{8}$. These trainee teachers generally are appointed as graduate teachers while undergoing NIE training and upon completion of training, similar to those in the PGDE program (see above).

${ }^{7}$ The Postgraduate Diploma in Education (PGDE) is a professional qualification for undergraduate degree holders and is synonymous to the Postgraduate Certificate in Education (PGCE) found in England, Wales and Northern Ireland, or the PGDE in Scotland.

${ }^{8}$ Those individuals who fail to qualify for the BA [Ed]/BSc [Ed] program with their 'A' level qualifications can still be hired by MOE as nongraduate teachers and sponsored for the Diploma in Education program at NIE. 
All the teacher-education programs offered by NIE generally offer several main components of study with the following approximate distribution:

(a) Education studies (20\%)

(b) Curriculum studies $(50 \%)^{9}$

(c) Practicum (25\%)

(d) Language enhancement and academic discourse skills (5\%)

In education studies, trainee teachers learn the key concepts and principles of education that are essential for effective teaching and reflective practice in schools. These courses also give the teachers the opportunity for in-depth study of some significant aspects of education. Curriculum studies modules are designed to provide teachers with the pedagogical skills to teach specific subjects in schools. The practicum is the internship (or field experience, or teaching practice) where trainee teachers spend a protracted amount of time in schools, ranging from one to 10 weeks in duration, depending on the program. During the practicum, trainee teachers are given opportunities to practice their craft under the guidance of one or more cooperating teachers and university faculty. Finally, language-

enhancement and academic-discourse skills provide teachers with the oral and written skills necessary for effective communication as teachers in both classroom teaching and in their professional interaction with others.

Therefore, all those who enter the teaching profession in Singapore as qualified teachers will definitely possess a professional qualification. It will either be the Bachelor of Arts (Education) or Bachelor of Science (Education) degree, Postgraduate Diploma in Education or the Diploma in Education. There is integration and close links between theory and practice in all NIE programs, and the curriculum studies and practicum components account for $75 \%$ of all coursework within the curriculum structure.

\section{Data and Measures}

The data presented in this chapter are derived from the Education Statistics Digest 2006, published by the Ministry of Education. The purpose of the Education Statistics Digest is to provide basic statistical information on education in Singapore. The statistical information - which includes data on schools, enrollment, teachers, educational outcomes and financesgives a quantitative description of the education scene. These data were compiled by the Management Information and Research Branch, Planning Division, Ministry of Education and was published in July.

The specific statistics referred to in the 2005 and 2006 Education Statistics Digests are: (a) secondary enrollment statistics by age, level and course, (b) summary statistics of teachers in schools, (c) teachers by academic qualification, (d) viceprincipals by academic qualification, and (e) principals by academic qualification.

\section{The Qualifications of the Teaching Force}

Table 1 shows the summary of statistics on teachers in schools by qualification. In 2005, there were 26,382 teachers (excluding viceprincipals and principals) comprising 18,620 graduates $(70.6 \%)$ and 7,762 nongraduates (29.4\%). The Ministry of Education has been steadily increasing the number of teachers in the workforce, but more importantly is the rise in the number of topquality scholar-teachers and graduate teachers as the ministry moves to upgrade the quality of the teaching profession (Lee, 2006; Shanmugaratnam, 2006c). In 2004, there were 25,716 teachers (excluding vice-principals and principals), comprising only 17,267 graduates $(67.1 \%)$ and 8,449

Table 1

Summary Statistics of Teachers in Schools, 2006.

\begin{tabular}{|llr|}
\hline Level/Type of School & Qualification & Teacher \\
\hline \multirow{3}{*}{ Primary } & Graduate & $5,827(31.3 \%)$ \\
& Nongraduate & $6,516(83.9 \%)$ \\
& & \\
& Graduate & $10,262(55.1 \%)$ \\
& Nongraduate & $1,233(15.9 \%)$ \\
Junior College \& Centralized Institutes & Graduate & $2,531(13.6 \%)$ \\
& Nongraduate & $13(0.2 \%)$ \\
& & \\
Overall & Graduate & $18,620(70.6 \%)$ \\
& Nongraduate & $7,762(29.4 \%)$ \\
& Total & 26,382 \\
\hline
\end{tabular}

${ }^{9}$ In the diploma and degree programs, curriculum studies also include other courses that aim to cover and reinforce the knowledge (concepts and principles) of different subject content in the school curriculum.

${ }^{10}$ Education Statistics Digest 2006, Planning Division, Ministry of Education, 2006. 
Table 2

Percentage of Teachers in Singapore by Academic Qualification by Level of Schools, 2006. ${ }^{11}$

\begin{tabular}{|c|c|c|c|c|}
\hline $\begin{array}{l}\text { Grade Level/ } \\
\text { Type of School }\end{array}$ & $\begin{array}{c}\text { Less than } \\
\text { Bachelor's } \\
\text { Degree }\end{array}$ & $\begin{array}{l}\text { Bachelor's } \\
\text { Degree }\end{array}$ & $\begin{array}{c}\text { Master's Degree or } \\
\text { Higher }\end{array}$ & $\begin{array}{l}\text { Total no. of } \\
\text { teachers by } \\
\text { school type }\end{array}$ \\
\hline Primary & $52.8 \%(6,516)$ & $45.5 \%(5,622)$ & $1.7 \%(205)$ & 12,343 \\
\hline Secondary & $10.7 \%(1,233)$ & $82.1 \%(9,441)$ & $7.2 \%(821)$ & 11,495 \\
\hline $\begin{array}{l}\text { Junior College \& } \\
\text { Centralized Institute }\end{array}$ & $0.5 \%(13)$ & $85.5 \%(2,175)$ & $14.0 \%(356)$ & 2,544 \\
\hline $\begin{array}{l}\text { Total no. of teachers } \\
\text { by academic qualification }\end{array}$ & $29.4 \%(7,762)$ & $65.3 \%(17,238)$ & $5.3 \%(1,382)$ & $100.0 \%(26,382)$ \\
\hline
\end{tabular}

${ }^{1}$ Education Statistics Digest 2006, Planning Division, Ministry of Education, 2006.

nongraduates (32.9\%) (Planning

Division, Ministry of Education, 2005).

The majority $(55.1 \%)$ of graduate teachers $(\mathrm{N}=10,262)$ were appointed to secondary schools, while 5,827 graduate teachers $(31.3 \%)$ are in primary schools. However, another important point to note is that the percentage of graduate teachers in the primary schools also has increased from 2004. The Ministry of Education's vision is not only to increase the number of graduate teachers, but also to increasingly appoint more of them to the primary schools. As a comparison, in 2004 only $29.9 \%$ (N $=5,169)$ of graduate teachers were placed in the primary schools. By contrast, $83.9 \%$ of nongraduate teachers $(\mathrm{N}=6516)$ taught in primary schools, while slightly over $16 \%$ of nongraduate teachers were in secondary schools, junior colleges and centralized institutes.

\section{Levels of Qualifications of the Current Teaching Force in Singapore}

Table 2 shows the percentage of teachers (excluding vice-principals and principals) in schools according to academic qualification and level of schooling in Singapore. Unlike Table
1 , where the teachers' qualifications are simply classified as either graduates or nongraduates, Table 2 provides a more detailed breakdown of their academic qualifications, viz., less than bachelor's degree, bachelor's degree, master's degree or higher. Such a breakdown helps to better understand the qualifications of the teaching workforce in terms of graduate qualifications beyond the undergraduate level. As Singapore's teaching profession moves towards a graduate workforce, there is a concomitant desire to encourage graduate teachers to upgrade their credentials with a master's degree.

As shown in Tables 1 and 2, the data indicate that in Singapore a majority of teachers have completed a college education $(\mathrm{N}=18,620)$. However, what is surprising is that despite $70.6 \%$ of the teaching force being graduates, only $5.3 \%(\mathrm{~N}=$ 1,382) of graduate teachers teaching in primary, secondary and junior colleges/centralized institutes hold at least a master's degree or higher (see Table 2).

Understandably, close to $60 \%$ of these teachers $(\mathrm{N}=821)$ are in secondary schools due to the higher proportion of graduate teachers in these schools. In years to come, the quality of Singapore's teaching workforce will no longer be determined by the number of graduate teachers (it is assumed that we will go almost completely to a graduate workforce) but by the number of graduates holding a master's degree or higher.

Despite the high percentage $(83.9 \%)$ of teachers with less than a bachelor's degree (see Table 1) in the primary schools, it is important to mention that all these (nongraduate) teachers have both ample pedagogical training and primary school curriculum content mastery, in their teaching subjects, for example, English, Mathematics, Science and Social Studies. The high mathematics and science achievements of Singapore fourth-grade students as reported in the Trends in Mathematics and Science Study (TIMMS) since 1995 (Mullis, Martin, Gonzalez, \& Chrostowski, 2003) is testimony to the high level of teaching competency of their primary school teachers.

In the secondary schools, most of the teachers with less than a bachelor's degree $(\mathrm{N}=1,233)$ are those who were certified to teach curriculum areas like Home Economics, Mother Tongue Languages, Physical Education, Art and Music. It was only after 1985 
Table 3

Percentage of Vice-Principals and Principals in Singapore by Academic Qualification by Level of Schools, 2006. ${ }^{12}$

\begin{tabular}{|c|c|c|c|c|}
\hline $\begin{array}{l}\text { Grade Level/ } \\
\text { Type of School }\end{array}$ & $\begin{array}{c}\text { Less than } \\
\text { Bachelor's } \\
\text { Degree }\end{array}$ & $\begin{array}{l}\text { Bachelor's } \\
\text { Degree }\end{array}$ & $\begin{array}{c}\text { Master's Degree or } \\
\text { Higher }\end{array}$ & $\begin{array}{c}\text { Total no. } \\
\text { of principals/VPs } \\
\text { by school type }\end{array}$ \\
\hline \multicolumn{5}{|l|}{ Primary } \\
\hline Vice-Principal & $21.3 \%(37)$ & $56.9 \%(99)$ & $21.8 \%(38)$ & 174 \\
\hline Principal & $38.9 \%(70)$ & $35.6 \%(64)$ & $25.5 \%(46)$ & 180 \\
\hline \multicolumn{5}{|l|}{ Secondary } \\
\hline Vice-Principal & $0.5 \%(1)$ & $40.5 \%(77)$ & $59.0 \%(112)$ & 190 \\
\hline Principal & - & $57.1 \%(96)$ & $42.9 \%(72)$ & 168 \\
\hline \multicolumn{5}{|c|}{ Junior College \& Centralized Institute } \\
\hline Vice-Principal & - & $72.0 \%(18)$ & $28.0 \%(7)$ & 25 \\
\hline Principal & - & $58.8 \%(10)$ & $41.2 \%(7)$ & 17 \\
\hline $\begin{array}{l}\text { Total no. of principals/VPs } \\
\text { by academic qualification }\end{array}$ & $14.3 \%(108)$ & $48.3 \%(364)$ & $37.4 \%(282)$ & 754 \\
\hline
\end{tabular}

${ }^{12}$ Education Statistics Digest 2006, Planning Division, Ministry of Education, 2006.

that NIE began developing degree programs in these areas. In fact, NIE will be offering for the first time, a degree program to train Home Economics teachers for secondary schools, in 2007.

Table 3 shows the percentages of vice-principals and principals in schools according to academic qualification and level of schooling in Singapore in 2004 and 2005 respectively.

From Table 3, every secondary school's principal $(\mathrm{N}=168)$ has at least a bachelor's degree. All viceprincipals $(\mathrm{N}=37)$ and principals $(\mathrm{N}$ $=70$ ) with less than a bachelor's degree are found in the primary schools, except for one vice-principal in a secondary school. More importantly, the number of school leaders in primary schools with at least a bachelor's degree or higher $(\mathrm{N}$ $=247$ ) have increased from 2004 $4^{13}$.

This increase also is reflected in a concomitant decrease in the number of school leaders with less than a bachelor's degree $(\mathrm{N}=107)$.

In 2004, there were a total of only 218 primary school leaders (vice-principals $=117$; principals $=$
101) who had such qualifications of at least a bachelor's degree or higher. In 2005, that number increased to 247 (vice-principals $=137$; principals $=110$ ), which is about a $13 \%$ increase. This increase is consistent with the MOE strategy to upgrade the academic qualifications of the overall teaching workforce, and notably that of the school leadership.

What is most telling is that the number of vice-principals and principals with a master's degree or higher also have increased from a year ago, where there were only a total of 115 (vice-principals $=40$; principals $=75)$ such individuals in 2004 as compared with 184 (vice principals $=112$; principals $=72$ ) in 2005. The greater increment is in the vice-principal category. It would not be inconceivable in the near future for the Ministry of Education to expect all school leaders across all school types to have at least a master's degree.

\section{Secondary-Grade-Level Teachers' Subject Qualifications and Subjects Taught in School \\ Degree holders with training in the}

fields of science, humanities and mathematics are strongly encouraged to teach at the secondary-school level. And trainee teachers specializing in secondary-school teaching in the PGDE program at NIE will be assigned to study two curriculum areas by the MOE. It is preferable that students major in two subject-matter areas in university. For a subject matter to be considered as the student's main or first area of instruction, it must have been read as a major up to the third year of the student's university-degree program. For the second curriculum area, the student must have read the subject in the first year or have taken at least two relevant courses in any of the three years at university.

Table 4 shows the various secondary-school subject areas that correspond to the (training) subjects offered by the universities and the curriculum studies assigned to teachers in NIE.

\footnotetext{
${ }^{13}$ The data from Education Statistics Digest 2004, Planning Division, Ministry of Education, 2005 has since been updated with the current Education Statistics Digest 2006 in the MOE website.
} 
Table 4

Matching Teaching Subjects (Fields) with Subjects (Majors) offered by Universities and Curriculum Studies Assigned in NIE

\begin{tabular}{|lll|}
\hline Teaching Subjects (Fields) & Subjects (Majors) offered by Universities & Curriculum Studies at NIE \\
\hline English Language & Communication Studies & English \\
& English Language & \\
& English Literature & \\
& Geography & \\
& History & Mathematics \\
& Law & \\
& Theatre Studies & \\
\hline \multirow{2}{*}{ Mathematics } & Applied Mathematics & \\
& General Mathematics & \\
& Mathematics & \\
& Mathematics with Management Science & \\
& Chemical Engineering & \\
& Civil and Structural Engineering & \\
& Computer Engineering & \\
& Electrical \& Electronic Engineering & \\
& Environment Engineering & \\
& Industrial and Systems Engineering & Materials Engineering \\
Mechanical \& Production Engineering
\end{tabular}

Science

Biology

Biology

Biology

Biochemistry

Biological Science

Botany

Life Sciences

Medicine

Microbiology

Pharmacy

Physiology

Zoology

Chemistry

Biochemistry

Chemistry

Chemistry

Chemistry with Management

Medicine

Pharmacy

Chemical Engineering

Materials Engineering and/or Science

Physics

Applied Physics

Physics

Biological Science

Physics

Physics in Technology

Civil Engineering

Electrical \& Electronic Engineering

Materials Engineering and/or Science

Mechanical \& Production Engineering

Social Studies

$\begin{array}{ll}\text { Economics } & \text { Economics } \\ \text { Geography } & \text { Geography } \\ \text { History } & \text { History }\end{array}$

Economics

Geography

History 
Table 5 summarizes the number of secondary-school teachers who are trained to teach the various subjects as their first or second teaching subjects. It is to be noted that teachers who graduate from NIE are centrally deployed to schools by the MOE. In the deployment of teachers to schools, the MOE takes into account the subject vacancies in the schools and deploys teachers who have been trained in the relevant subjects, be it their first or second teaching subject, to match these vacancies.

\section{Issues of Out-of-Field Teaching and Underqualified Teachers}

There generally is a call worldwide to ensure that a nation's school system is staffed by talented and qualified teachers. In response, many countries have implemented different strategies to recruit the best and train enough teachers to meet their needs. These different programs and initiatives include, but are not limited to, the following: (a) more stringent licensing standards, (b) higher admission academic criteria for teacher-education programs, (c) diverse alternative-certification programs, (d) challenging career prospects and financial incentives for midcareer professionals from other fields to enter teaching, and (e) retention benefits to encourage teachers to stay in the profession, or return to teaching after retirement or on a part-time basis (Ingersoll, 2003; Shanmugaratnam, 2006a).

The challenge to recruiting more good teachers for every school is not just in terms of numbers. For

Singapore the challenge is to support teachers already in the classroom and to inject more quality into education. One strategy is to improve pupil-

Table 5

Summary Statistics on Teaching Subjects of Secondary School Teachers, 2005..$^{14}$

\begin{tabular}{|lcc|}
\hline Teaching Subjects (Fields) & First teaching subject & Second teaching subject \\
\hline English Language & 1,745 & 1,675 \\
Mathematics & 1,618 & 2,068 \\
Science & 1,115 & 762 \\
Social Studies & 1,414 & 776 \\
\hline
\end{tabular}

${ }^{14}$ Personnel Division, Ministry of Education, 2005.

teacher ratios, which already has resulted in implementation of 20 students per class for Primary 1 schools since 2005 and for Primary 2 classes beginning in 2006. Also, with more teachers in every school, teachers have expanded opportunities to reflect on their teaching, to plan and make lessons more interesting, to spend quality time with their students (both in and out of class), and to participate in professional learning and sharing (Lee, 2006). However, schools still have problems with underqualified teachers and poor-quality teaching even though there are numerous highly trained teachers in each school. The issue has to do with out-of-field teaching.

Out-of-field teaching is defined as "teachers assigned to teach subjects for which they have little education or training" (Ingersoll, 2004, p. 46). Ingersoll (2004) argues that this phenomenon is due to a complex interplay of factors that affect how schools are organized and how teachers are recruited and deployed in schools. His premise is that out-offield teaching is a viable strategy employed by school administrators to help balance between specific organizational demands and resource constraints experienced by schools.

As mentioned earlier, various administrative practices and policies of recruitment, training, and deployment of teachers in the
Singapore school system are closely interrelated and managed centrally by the Ministry of Education. For this reason, out-of-field teaching is not considered a significant cause of underqualified and poor-quality teaching by the authors of this paper. The next few sections of this paper will briefly explain the reasons for this assertion.

First, the Ministry of Education recruits teachers for the whole school system based on yearly estimates of needs provided by principals and MOE's own forecasting and planning. The planning is based on statistical trends as well as actual information received from teachers, with the result that the ministry can estimate the numbers of teachers who might resign after serving their teaching bond (see section on "Academic Qualifications Required to Become Teachers' above) or who might resign in the following year upon reaching retirement age. This planning enables the MOE to hire teachers in its twice-yearly recruitment campaign to fill these anticipated "shortages." Furthermore, Singapore follows a centrally defined, but locally implemented, curriculum within each of the three secondary-school streams (or course of study). With well-established curriculum guidelines, student enrollment in specific subject classes are 
predetermined and do not change dramatically across academic semesters or grade levels ${ }^{15}$. This predictability has implications for yearly staffing decisions by the MOE and allows it to plan and coordinate teacher recruitment and deployment.

Second, the issue of qualified teachers has been addressed by the system in that the ministry hires both graduate and nongraduate teachers and sponsors their training at NIE. Graduate teachers with acceptable academic majors (or teaching subjects) will be provided with pedagogical training. For nongraduate teachers, both content knowledge and pedagogy coursework are addressed in their programs. As such, all teachers graduating from NIE programs are qualified to teach, both in core content areas and pedagogical practices. Since NIE works closely with the MOE in establishing the required standards, the qualifications of Singapore teachers are seldom questioned.

Third (though closely related to the second reason), all teachers, regardless of what position they are hired to fill, are trained to teach in two curriculum areas ${ }^{16}$ in their respective NIE programs. This strategy gives school administrators greater flexibility and capacity to deploy their teachers appropriately. Generally, administrators consult with their teachers about the specific subject they prefer to teach. This allows a better fit between teacher preparation at NIE and the actual teaching assignments in schools. If a school has out-of-field teaching in one or more of the subjects, this situation usually will last no longer than six months, as will be explained in the next paragraph.

Fourth, the ministry attempts to make staffing decisions-both appointment and deploymentbased on expected student enrollment and feedback provided by principals at the end and middle of each year. Since NIE graduates two cohorts of teachers, in November and in May, the ministry can deploy these teachers to schools by January and by June ${ }^{17}$. So, if a school faces any shortage due to sudden resignations, anticipated maternity leave, approved professional-development leave or unexpected out-of-field teaching, such situations can be corrected or alleviated within six months.

Furthermore, teachers are allowed to seek deployment to other schools where there are shortages and where their content and teaching expertise are required. And schools can actively seek out appropriate staff to help fill openings. Such yearly movement of teachers helps the whole system to balance itself and reach a state of equilibrium in the levels of teacher supply and demand.

Schools in Singapore are funded by the Ministry of Education and generally schools have their teachers appointed by the ministry ${ }^{18}$. The result is that there is only limited competition for teachers across schools and no real shortage of teachers. If the ministry launches a new curriculum or initiative, the ministry will meet those new needs by the allocation of sufficient funds, resources and increased recruitment and appointment of teaching staff, as has been done in recent years. Furthermore, in its staffing plans and decisions, the ministry takes into consideration such factors as assignment guidelines (i.e., number of teaching periods per week), class size, student enrollment, teacher resignations, etc. The result is that out-of-field teaching is not considered a major cause of underqualified teacher placement in Singapore.

\section{Conclusions and Implications}

The purpose of this paper is to describe the process of recruitment and training the teachers for the Singapore education system. The candidates are recruited by the Ministry of Education based on a set of criteria developed in close consultation with the NIE, which is to date the sole teacher training institute in Singapore. Depending on the entry qualifications of the candidate, one can be trained to each at the primary or secondary level. To teach at the primary level, one need not have an undergraduate degree. But to teach at the secondary level, one must have at least an undergraduate degree in a particular discipline. All candidates accepted by the Ministry will be sent to NIE for training before they can be appointed to the education service. However, as discussed in this paper, the vision of the Ministry of Education is to increase the number of graduate teachers in its workforce, especially, by increasingly appointing more of them to the primary schools. From the figures quoted, with only less that $30 \%$ of the current teaching workforce having less than a bachelor's degree, this vision would become a reality in the not too distant future.

With regards to the issues of underqualified teachers and out-offield teaching, they are not considered problems in the Singapore

\footnotetext{
${ }^{15}$ Student enrollment and teacher numbers remain quite consistent within each school and do not fluctuate drastically from year to year because of the standardized national curriculum.

${ }^{16}$ Teachers in Singapore teach particular subjects, like mathematics, rather than courses such as algebra or trigonometry. As such, mathematics teachers are qualified to teach all topics within the field of mathematics. ${ }^{17}$ The Singapore school academic year runs from January to May (semester 1) and from July to November (semester 2). Therefore, graduating teachers from NIE are deployed to schools at the beginning and middle of the year for each new semester. ${ }^{18}$ Independent schools have the autonomy to "hire and fire" their own teachers, and to set their own school fees.
} 
context. This is because the various administrative practices and policies of recruitment, training, and deployment of teachers in the Singapore school system are closely interrelated and managed centrally by the Ministry of Education. For example, NIE works closely with the MOE in establishing the required standards of subject content and pedagogy expected of teachers graduating from NIE. As a result the issue of underqualified teachers does not exist. And since MOE oversees all the schools in Singapore, it has a good overview of where the surpluses and shortages are. This helps it to efficiently redeploy teachers to schools that need their expertise, hence eliminating the issue of out-offield teaching effectively.

In conclusion, it would not be incorrect to say that the Singapore teaching force is a well qualified one that serves the Singapore education system well. 


\section{References}

Chen, P. (2000). Speech by Peter Chen, Senior Minister of State for Education, at the First Symposium on Teaching and Learning in Higher Education on July 6, 2000. Retrieved February 20, 2007, from http://www.moe.gov.sg/speeches/200 0/sp06072000.htm

Goh, C. T. (1997). Shaping our future: Thinking schools, learning nation, Speech by Prime Minister Goh Chok Tong at the Opening of the 7th International Conference on Thinking on June 2, 1997, at the Suntec City. Retrieved February 20, 2007, from

http://www.moe.gov.sg/speeches/199 7/020697.htm

Goh, K. C., \& Chang, A. (2002). Teachers and teacher education in Singapore. In Teachers and teacher education in Southeast Asian countries (pp. 292-325). Bangkok, Thailand: SEAMEO-RIHED.

Gopinathan, S. (1999). Preparing for the next rung: Economic restructuring and educational reform in Singapore. Journal of Education and Work, 12(3), 295-308.

Ingersoll, R. (2003). Out-of-field teaching and the limits of teacher policy. Seattle, WA: Center for the Study of Teaching and Policy, University of Washington.

Ingersoll, R. (2004). Why some schools have more underqualified teachers than others. In D. Ravitch (Ed.), Brookings papers on education policy 2004 (pp. 45-88). Washington, DC: Brookings Institution Press.
Lee, H. L. (2006). Speech by Lee Hsien Loong, Prime Minister, at the Teachers' Day Rally 2006 on August 31, 2006. Retrieved February 20, 2007, from

http://www.moe.gov.sg/speeches/2006/sp 20060831.htm

Lee, Y. S. (1996). Speech by Mr. Lee Yock Suan, Minister for Education, at the Promotion Ceremony and Launch of the Education Service Mission Statement on October 28, 1996. Retrieved February 20, 2007 , from

http://www.moe.gov.sg/press/1996/st00 396.htm

Ministry of Education (MOE) (1999). MOE's Addendum to the President's Address. Retrieved February 20, 2007, from http://www.moe.gov.sg/speeches/1999/sp 081099.htm

Mullis, I.V., Martin, M.O., Gonzalez, E.J., \& Chrostowski, S.J. (2003). TIMMS 2003 international mathematics and science reports. Chestnut Hill, MA: TIMMS \& PIRLS International Study Center, Lynch School of Education, Boston College.

Planning Division, Ministry of Education (2006). Education Statistics Digest 2006. Retrieved February 20, 2007, from http://www.moe.gov.sg/esd/Default.htm

Shanmugaratnam, T. (2003). Speech by Tharman Shanmugaratnam, Acting Minister for Education, at the MOE Work Plan Seminar 2003 at Ngee Ann Polytechnic on October 2, 2003. Retrieved February 20, 2007, from

http://www.moe.gov.sg/speeches/2003/sp 20031002.htm
Shanmugaratnam, T. (2004). Speech by Tharman Shanmugaratnam, Minister for Education, at the MOE Work Plan Seminar 2004 at Ngee Ann Polytechnic on September 29, 2004. Retrieved February 20, 2007, from

http://www.moe.gov.sg/speeches/2004/sp 20040929.htm

Shanmugaratnam, T. (2006a). Speech by Tharman

Shanmugaratnam, Minister for

Education and 2nd Minister for

Finance, at the Teachers' Mass

Lecture 2006 at the Singapore Expo on September 4, 2006. Retrieved February 20, 2007, from http://www.moe.gov.sg/speeches/2006/sp 20060904.htm

Shanmugaratnam, T. (2006b). Speech by Tharman Shanmugaratnam, Minister for Education and 2nd Minister for Finance, at the MOE NE Forum for Principals at the MOE Edutorium on August 24, 2006. Retrieved February 20, 2007, from http://www.moe.gov.sg/speeches/2006/sp 20060824.htm

Shanmugaratnam, T. (2006c). Speech by Tharman Shanmugaratnam, Minister for Education, at the 2006 Teaching Scholarship Presentation Ceremony at the Suntec Singapore International Convention \& Exhibition Centre on August 4, 2006. Retrieved February 20, 2007, from http://www.moe.gov.sg/speeches/2006/sp 20060804.htm

Sharpe, L., \& Gopinathan, S. (2002). After effectiveness: New directions in the Singapore school system? Journal of Education Policy, 17(2), 151-166. 
Teo, C. H. (1998). Ministerial statement by Radm (NS) Teo Chee Hean, Minister for Education, at the Budget Debate on March 19, 1998. Retrieved February 20, 2007, from http://www.moe.gov.sg/speeches/1998/1 90398. htm

Teo, C. H. (1999). Ministerial statement by Radm (NS) Teo Chee Hean, Minister for Education \& 2nd Minister for Defense, at the Committee of Supply Debate, Fiscal Year 1999 in Parliament on March 17, 1999. Retrieved February 20, 2007, from

http://www.moe.gov.sg/speeches/1999/sp 170399.htm

Teo, C. H. (2000). Speech by Radm (NS) Teo Chee Hean, Minister for Education \& 2nd Minister for Defense, at the 2nd Teaching Scholarship Presentation Ceremony on July 15,2000 . Retrieved February 20, 2007, from http://www.moe.gov.sg/speeches/2000/sp 15072000a.htm

Teo, C. H. (2001). Making an ability driven education happen, Ministry of Education Committee of Supply Debate Fiscal Year 2001, Minister's First Reply on Schools on March 15, 2001. Retrieved February 20, 2007, from

http://www.moe.gov.sg/speeches/2001/sp 15032001.htm 


\section{CHAPTER 7 \\ The Qualifications of the Teaching Force in Thailand}

Pruet Siribanpitak

Chulalongkorn University

And

Siriporn Boonyananta

Office of the Education Council

\section{Introduction}

The modern education system stems from the reforms established by the 1999 Education Act which put in place administrative structures, decentralization and a learner centered focus around the reform process (Figure 1). This system is based on nine years of compulsory education (enacted in 2003) with 12 years of free basic education guaranteed by the constitution. All types of education can be providedby educational institutions and also by learning centers organized by individuals, families, communities, private groups, local administration organizations, professional bodies, religious institutions, welfare institutes, and other social institutions (Ministry of Education, 2006; Office of the Education Council, 2006)

\section{Formal Education}

Formal education services are provided mainly to those within the school system, and are divided into basic and higher education.

\section{Basic Education}

Basic education is provided by early childhood development institutions, schools, and learning centers, and covers pre-primary education, six years of primary, three years of lower secondary, and 3 years of upper secondary education.

Over $74 \%$ of 3- to 6-year-old children totaling just over 1.8 million students receive early childhood education. Whereas the majority of services are provided as part of the government primary schools, the Ministry of Education has actively encouraged private schools and local governments to take a more active role. As a result, there has been a significant private-sector expansion, particularly in metropolitan Bangkok where it comprises $59 \%$ of total provision, against the national average of $28 \%$.

By 2005, gross enrollment rates for basic education reached $104 \%$ for primary education (5.8 million students), $95 \%$ for lower-secondary education (2.7 million students), and $64 \%$ for upper-secondary education (1.7 million students divided between 1 million in general education and 700,000 in vocational education).

\section{Higher Education}

Higher education at the diploma, associate, and degree levels are provided in universities, institutes, colleges and other types of institutions.

\section{Nonformal Education}

Nonformal education services are provided by both public and private bodies. Services provided by the Office of the Nonformal Education Commission primarily target those outside the school system, i.e. infants and pre-school children, the schoolage population who have missed out on formal schooling, and the overschool-age population. Currently, services have been expanded to cover specific target groups, including prison inmates, the labor force, the disabled, conscripts, agriculturists, the aged, hill tribe people, local leaders, slum dwellers, Thai Muslims, religious practitioners, those having no opportunity to further their studies in formal schooling after compulsory education, Thai people in foreign countries, and other special groups.

\section{Informal Education}

Informal education enables learners to learn independently in line with their interests, potential, readiness, and the opportunities available from individuals, society, environment, the media, and other sources of knowledge. 
Figure 1

The Thai Education System, 2006. ${ }^{1}$

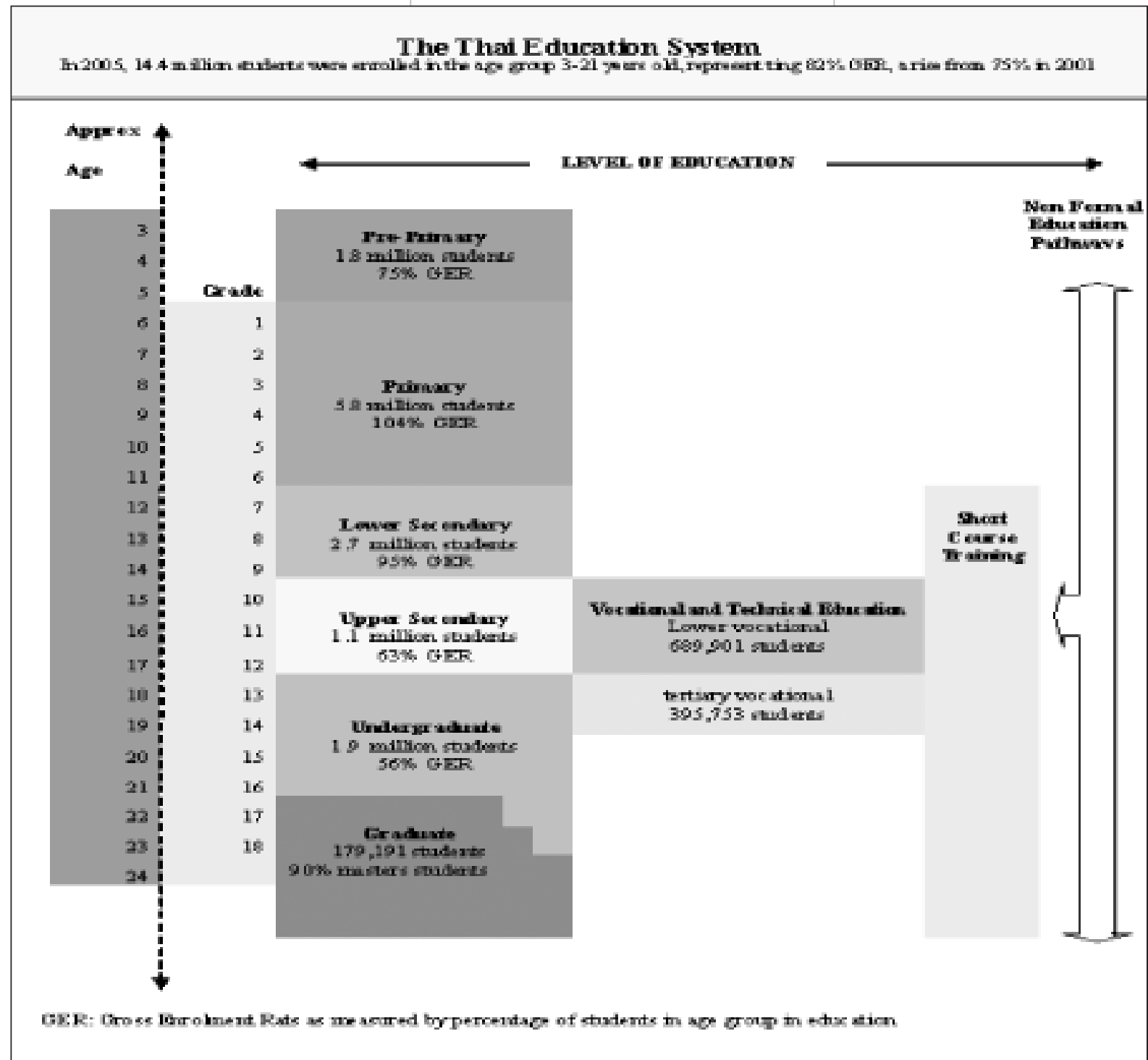

${ }^{1}$ Ministry of Education, 2006.

\section{Educational Administration and Management}

Carried out in accordance with the 1999 National Education Act and the 2002 Bureaucratic Reform Bill, the major reform of educational administration and management has been the merging of three agencies consisting of the Ministry of Education, the Ministry of University Affairs and the Office of the National Education Commission - into a single Ministry of Education (Office of the
Education Council, 2006).

The Ministry of Education is responsible for promoting and overseeing all levels and types of education under the administration of the state. However, local education administration is under the supervision of the Ministry of Interior. In addition, other ministries undertake management of education in specialized fields or for specific purposes (Figure 2).

Education administration and management in Thailand is classified into three categories (Office of the Education Council, 2006):

\section{Administration and Management} of Education by the State

Education in Thailand is administered and managed by the government through central agencies, through educational service areas, and by educational institutions.

In accordance with amendments of the National Education Act, the Ministry of Education is responsible for promoting and overseeing all 


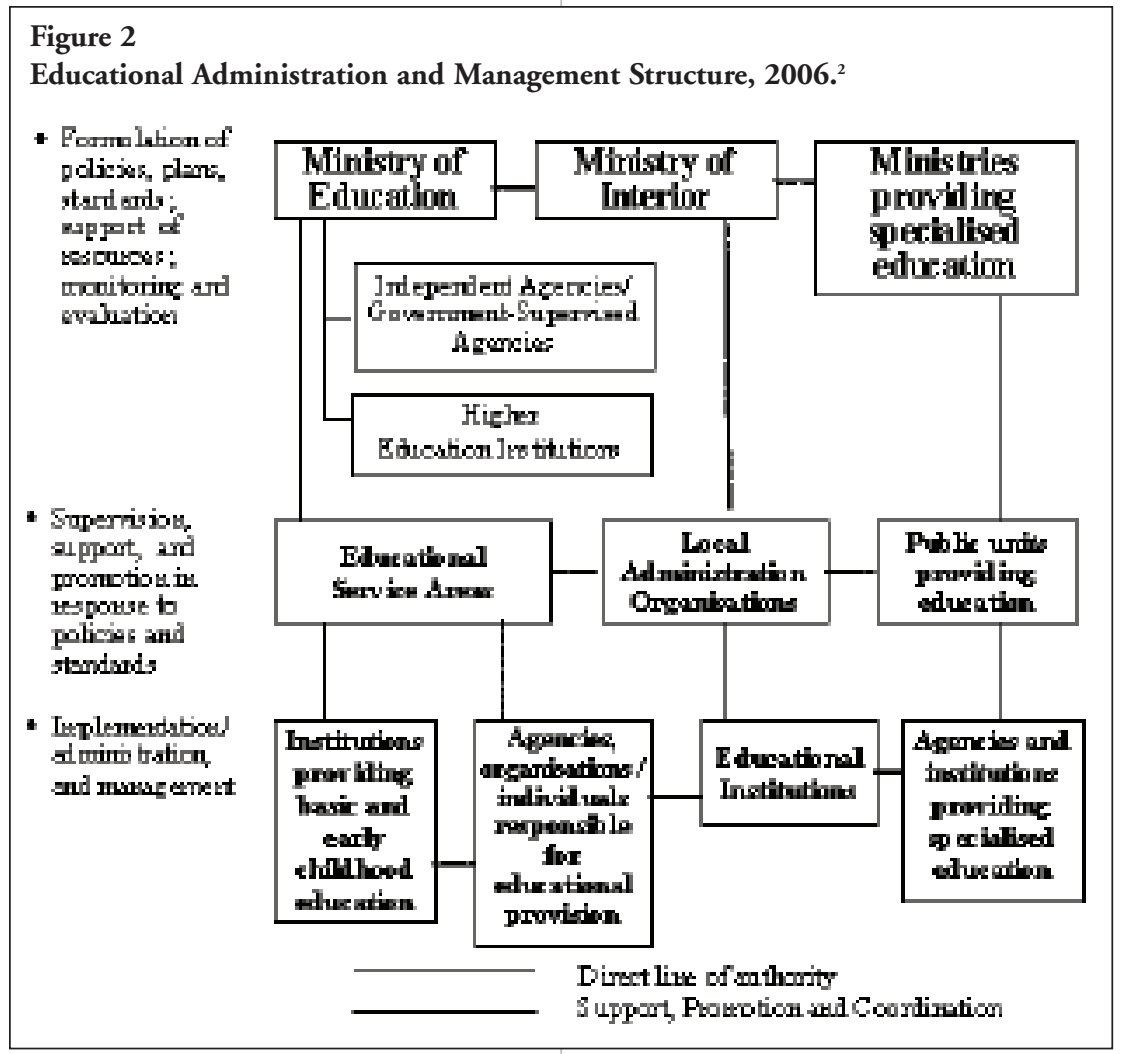

${ }^{2}$ Office of the Education Council, 2006.

levels and types of education; formulation of policies, plans and standards; mobilization of resources for education; promotion and coordination in religious affairs, arts, culture, and sports relating to education; as well as the monitoring, inspection, and evaluation of educational provisions.

Administration and management at the central level is under the responsibility of five main bodies: the Office of the Permanent Secretary; the Office of the Education Council (OEC); the Office of the Basic Education Commission; the Office of the Vocational Education Commission; and the Office of the Higher Education Commission.

In conformity with a directive to decentralize authority for educational administration, the Basic Education Commission has established 175 educational service areas in 76 provinces, with 172 areas in the provinces and the remaining three in moving toward transformation to state-supervised institutions or autonomous universities that function as legal entities. The new structure will enable each institution to develop its own administration and management system with greater flexibility and academic freedom under the supervision of an institutional council empowered by its own Act.

\section{Administration and Management of Education by Local Administration Organizations}

In accordance with the National Education Act, local administration organizations can provide education services at any or all levels commensurate with their readiness, suitability, and the requirements of the local area. The Ministry of Education prescribes criteria and procedures for assessing readiness to provide education services, and assists in enhancing their capability in line with the policies and required standards. Additionally, the Ministry advises on the budgetary allocations provided by local administration organizations.

\section{Administration and Management of} Education by the Private Sector

The state is responsible for overseeing administration and management as well as for monitoring the quality and standards of private educational institutions, both those that provide general education and those offering vocational education. At present, most private institutions are forprofit schools, with a few prestigious institutions managed by Christian denominations.

\section{Teachers' Salary Structure}

When individuals join the teaching service, they are placed on salary 
Table 1

New Teacher Classification Framework, 2004. ${ }^{3}$

\begin{tabular}{|c|c|c|c|c|}
\hline \multirow[t]{2}{*}{ Position } & \multirow[t]{2}{*}{ Academic Status } & \multicolumn{2}{|c|}{ Monthly Salaries } & \multirow{2}{*}{$\begin{array}{c}\text { Extra Monthly } \\
\text { Allowance }\end{array}$} \\
\hline & & Beginning & Highest & \\
\hline 1. Assistant Teacher & - & $\begin{array}{c}8,360 \text { B } \\
\text { (209 US\$) }\end{array}$ & - & - \\
\hline \multirow[t]{5}{*}{ 2. Teacher } & - & $\begin{array}{c}11,470 \text { \$ } \\
\text { (287 US\$) }\end{array}$ & - & - \\
\hline & 2.1 Experienced Teacher & $\begin{array}{c}14,810 \text { B } \\
(370 \text { US\$) }\end{array}$ & $\begin{array}{c}32,250 \text { В } \\
(806 \text { US\$) }\end{array}$ & $\begin{array}{c}3,500 \text { B } \\
(88 \text { US\$) }\end{array}$ \\
\hline & 2.2 Higher Experienced Teacher & $\begin{array}{c}18,180 \text { B } \\
(455 \text { US\$) }\end{array}$ & $\begin{array}{c}45,620 \text { B } \\
(1,141 \text { US\$) }\end{array}$ & $\begin{array}{c}5,600 \text { B } \\
(140 \text { US\$) }\end{array}$ \\
\hline & 2.3 Expert Teacher & $\begin{array}{c}22,230 \text { B } \\
(556 \text { US\$) }\end{array}$ & $\begin{array}{c}48,600 \text { \$ } \\
(1,215 \text { US\$) }\end{array}$ & $\begin{array}{c}9,900 \text { B } \\
\text { (248 US\$) }\end{array}$ \\
\hline & 2.4 Specialized Teacher & $\begin{array}{l}27,450 \text { B } \\
(686 \text { US\$) }\end{array}$ & $\begin{array}{c}61,860 \text { B } \\
(1,547 \text { US\$) }\end{array}$ & $\begin{array}{c}13,000 \text { \$ } \\
(325 \text { US\$) }\end{array}$ \\
\hline
\end{tabular}

${ }^{3}$ The Ministry of Education, 2006; OBEC, 2004.

scales that correspond to their qualifications and prior experience and the civil service salary structure. The base level salary for teachers with a four-year bachelor's degree is 7,630 baht (190 US\$) and for those with a master's degree is 9,320 baht (233 US\$) whereas other professionals such as doctors and engineers earn about 30,000-50,000 baht (7501,250 US\$).

According to the Teachers and Educational Personnel Act of B.E. 2546 (2003) there is a six-scale teacher classification framework based on academic status for a new salary structure. The classification ranges from assistant teachers, teachers, experienced teachers, higher experienced teachers, and expert teachers, to specialized teachers. The entry requirement for assistant teachers is either a five-year or $4+1$ year of post secondary pre-service teacher training. An assistant teacher salary is 8,360 baht (209 US\$), and a teacher's salary is 11,470 baht (287 US\$). Teachers who get promoted to a higher level of academic status based on performance will get an extra monthly allowance. The scales of the additional allowance are 3,500 baht (88 US\$), 5,600 baht (140 US\$), 9,900 baht (248 US\$), and 13,000 baht (325 US\$) for experienced teachers, higher experienced teachers, expert teachers, and specialized teachers respectively. (See Table 1)

By this new framework the teacher will earn a higher monthly salary when compared with the previous one. (See Table 2) The aim is not only to attract talented high school students into pre-service teacher training programs but also to attract talented graduates into the profession.

\section{Teacher Preparation Requirements and Standards}

Teacher preparation in Thailand has always been the responsibility of government teacher-training institutes. In 2006, there were 56 faculties of education in 56 state universities throughout the country, 40 of them at Rajabhat universities. An entrance examination is required for all pre-service teacher education programs. Prior to 2005, entrants to
Table 2

Previous Teacher Classification Framework ${ }^{4}$

\begin{tabular}{|lcc|}
\hline $\begin{array}{l}\text { Position } \\
\text { (Baht) }\end{array}$ & Salary Scales & Monthly Salaries \\
\hline 1. Teacher (Level 1) & $1-3$ & $4,230-13,550$ \\
2. Teacher (Level 2) & $2-4$ & $5,050-16,650$ \\
3. Instructor (Level 1) & $3-5$ & $6,210-20,340$ \\
4. Instructor (Level 2) & $5-6(7)^{*}$ & $9,320-25,180(30,710)^{*}$ \\
5. Instructor (Level 3) & $6-8(9)^{*}$ & $11,450-43,440(46,280)^{*}$ \\
\hline
\end{tabular}

${ }^{4}$ The Ministry of Education, 2006; OBEC, 2004.

a. *The salary scale and monthly salary will be upgraded to a higher scale according to the teacher's academic performance. 
teaching jobs had to complete a fouryear baccalaureate-degree program.

Since 2005, all teachers must obtain a teaching license ${ }^{(1)}$ signifying professional training (Teacher and Educational Personnel Act, 2003). This requires completion of a fiveyear bachelor's degree in teacher education. College graduates who complete a bachelor's degree in fields other than education must complete a one-year post-baccalaureate diploma in teacher training to obtain a teaching license. However, both the five-year undergraduate-degree and one-year post-graduate diploma programs must meet the standards of professional knowledge and experience set by the Teachers' Council (2006). The minimum is 30 credits in general education courses, 50 credits in pedagogy courses, 74 credits in subject-matter courses, and six credits of elective courses plus one year of student teaching ${ }^{(2)}$ or professional practice for the five-year bachelor's degree program. The minimum is 24 credits in pedagogy course plus one year of student teaching for the one-year graduate diploma program.

\section{Data and Measures}

The data presented in this chapter are divided into two parts, the first part comes from the Office of Basic Education Commission, academic year 2004 (See Table 3), and the second part of data comes from the school survey conducted by the Office of the Education Council (OEC), Ministry of Education (See Table 4-5).

Note

(1)According to the regulations of the Teachers' Council, teachers shall be required to renew their license every five years with certain evaluation criteria. (2) Prior to 2005, the requirement was one semester of student teaching.

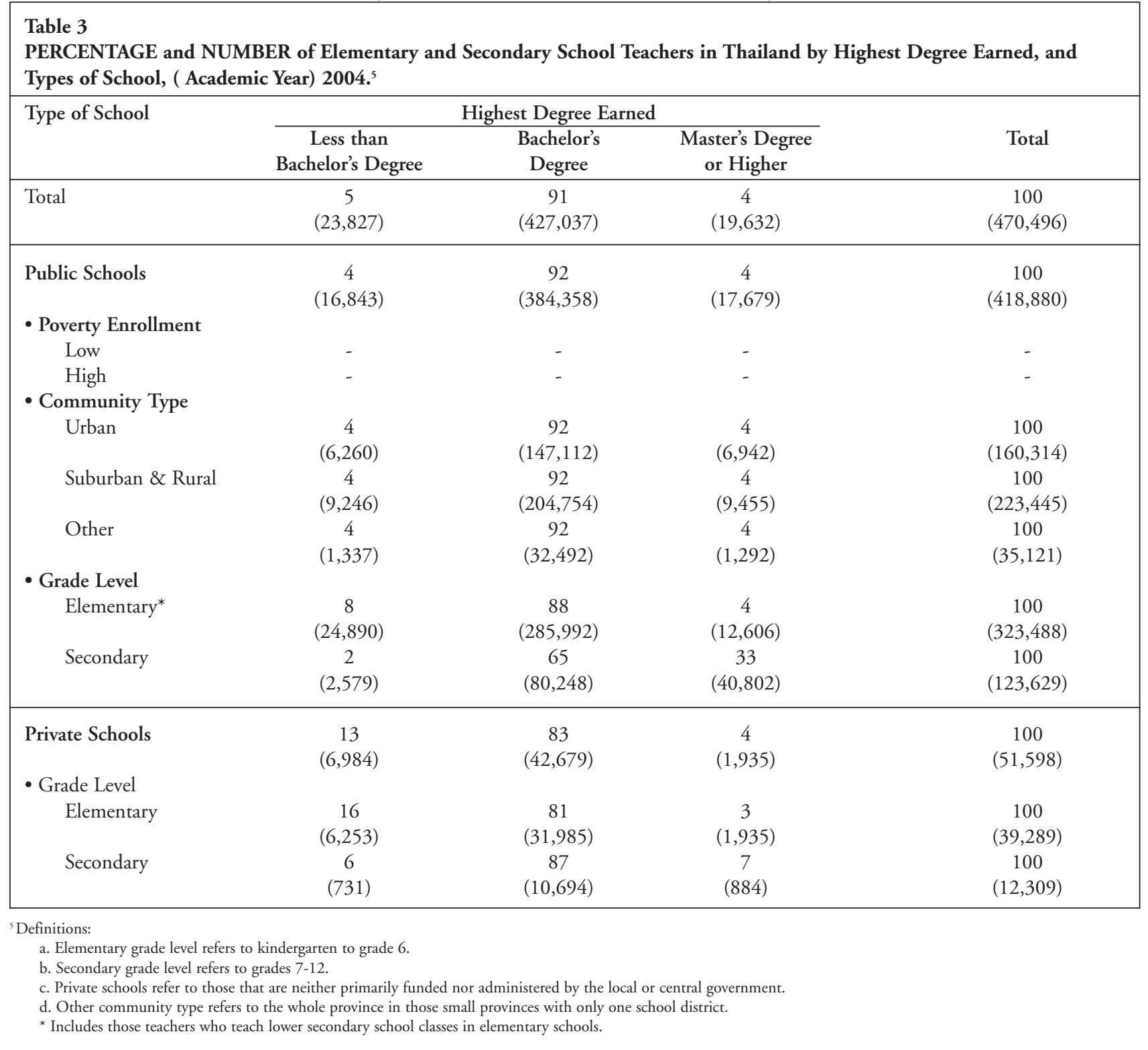




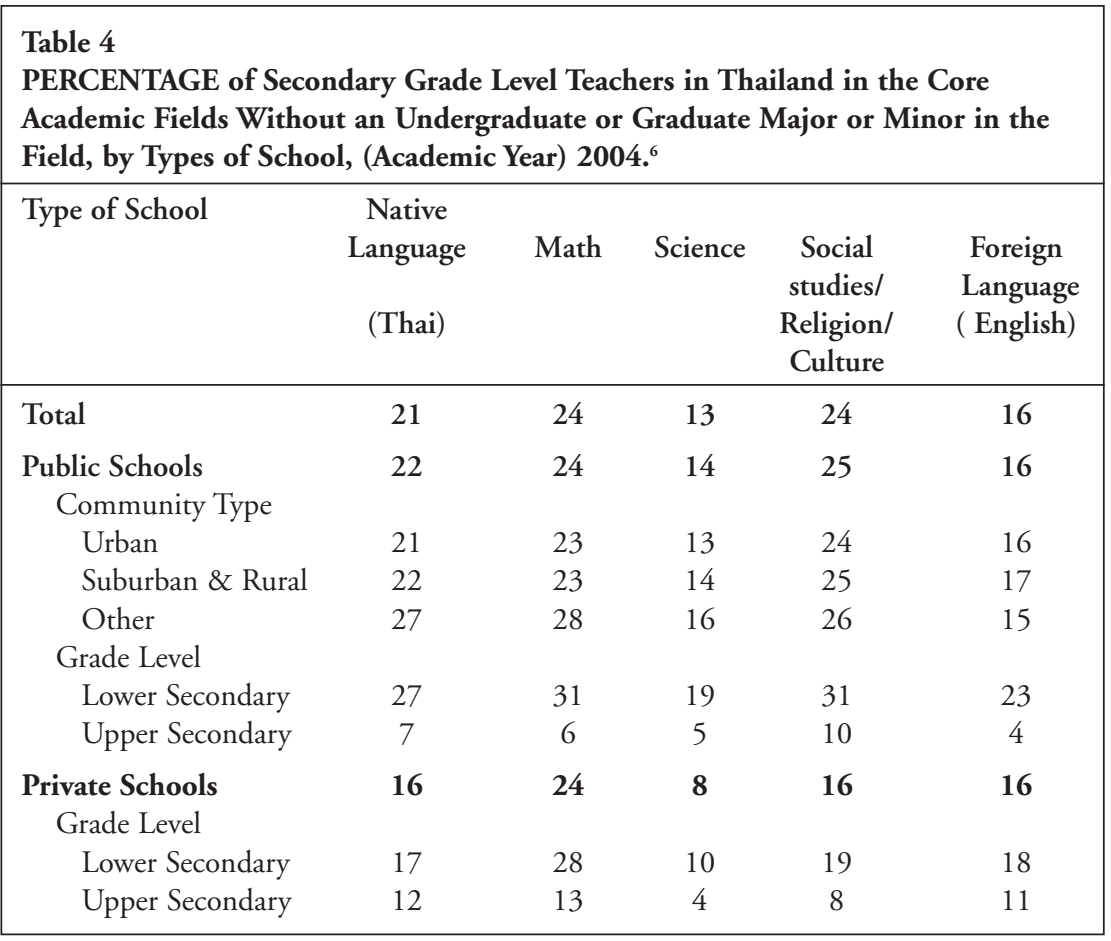

${ }^{6}$ Definitions:

a. The data of public schools were collected from 64 percent of the Educational Service Area Office (175 offices).

b. "Other" community type refers to the whole province in those small provinces with only one school district.

c. The data of private schools were collected from 37 percent of the Educational Service Area Office $(98$ offices).

\section{Table 5}

PERCENTAGE of Secondary Grade Level Teachers in Thailand in the Core Academic Fields Without an Undergraduate or Graduate Major in the Field, by Types of School, (Academic Year) 2004.7

\begin{tabular}{|lccccc|}
\hline Type of School & $\begin{array}{c}\text { Native } \\
\text { Language }\end{array}$ & Math & Science & $\begin{array}{c}\text { Social } \\
\text { studies/ } \\
\text { Religion/ } \\
\text { Culture }\end{array}$ & $\begin{array}{c}\text { Foreign } \\
\text { Language } \\
\text { ( English) }\end{array}$ \\
& & & & 26 & 20 \\
\hline Total & 24 & 26 & 15 & 26 & 20 \\
Public Schools & 24 & 26 & 15 & & \\
Community Type & 24 & 26 & 14 & 26 & 19 \\
$\quad$ Urban & 24 & 26 & 15 & 27 & 20 \\
$\quad$ Suburban \& Rural & 29 & 31 & 16 & 28 & 18 \\
$\quad$ Other & 30 & 34 & 20 & 33 & 26 \\
Grade Level & 9 & 8 & 7 & 13 & 7 \\
$\quad$ Lower Secondary & 20 & 26 & 10 & 18 & 17 \\
$\quad$ Upper Secondary & & & & & \\
Private Schools & 21 & 31 & 11 & 21 & 19 \\
Grade Level & 15 & 15 & 8 & 11 & 11 \\
$\quad$ Lower Secondary & & & & & \\
$\quad$ Upper Secondary & & & & & \\
\hline
\end{tabular}

${ }^{7}$ Definitions:

a. The data of public schools were collected from 64 percent of the Educational Service Area Office (175 offices).

b. "Other" community type refers to the whole province in those small provinces with only one school district.

c. The data of private schools were collected from 37 percent of the Educational Service Area Office (98 offices).

\section{The Qualifications of the Teaching Force}

The data in Table 3 showed that in the year 2004 most Thai elementary and secondary school teachers had completed undergraduate study. Ninety-one percent completed a bachelor's degree, 5\% held less than a bachelor's degree and 4\% held a master's degree or higher. There were pronounced differences among public schools and private schools. The data also showed that students in private schools had less access to qualified teachers. For example, 92\% of public school teachers completed a bachelors' degree as opposed to $83 \%$ of private school teachers while $4 \%$ of public school teachers held less than bachelor's degree as opposed to $13 \%$ of private school teachers. Moreover, about $33 \%$ of public secondary school teachers held a master's degree or higher compared with $7 \%$ of private secondary-school teachers.

The data also revealed similar qualifications of teachers among community types. On the other hand, there is no difference between suburban and urban schools in the percentage of teachers with degrees. For example, about $92 \%$ of teachers in urban, suburban and rural areas held a bachelor's degree and about $4 \%$ held a master's degree or higher. These phenomena represent equality in the qualifications of teachers among 176 educational service areas in Thailand.

Furthermore, there are differences in the qualifications of teachers between grade levels in public schools. For example, about 33\% of secondary school teachers have completed a master's degree or higher as opposed to $4 \%$ of elementary school teachers. 


\section{Out-of-Field Teaching}

The critical problem facing education and teachers in Thailand is twofold:

the lack of fit between teacher preparation and class assignments, and the lack of teachers in core areas. This is the result of the practice of out-of-field teaching - where teachers educated and trained in one field of study are assigned by school administrators to teach classes in another field of study.

As mentioned earlier, the data in Table 4 and 5 show the measurement of the out-of-field teaching at secondary level among the different types of school; school sectors, community types, and grade levels. Table 4 shows the percentage of teachers without an undergraduate or graduate major or minor in the field. Table 5 shows percentage of teachers without an undergraduate or graduate major in the field.

Each table indicates that there are many teachers assigned to teach classes in fields that do not match their educational background. The data in Table 4 show that $24 \%$ of teacher who teach mathematics and social studies classes have neither a major nor a minor in mathematics or social studies, or related disciplines. These problems extend to other classes even Thai language classes, where about $21 \%$ of all those teaching Thai language classes have neither a major nor a minor in Thai.

The data reveal less difference between community types. For example, $24 \%$ of secondary teachers who teach social studies classes in urban schools have neither a major nor a minor in social studies opposed to $25 \%$ of those who teach social studies classes in suburban and rural schools. In a piece of controversy, there is more difference among grade levels, teachers who teach at the lower-secondary level have been assigned to teach classes in fields that do not match their educational background more than those who teach at the upper-secondary level. For example, in public schools, 31\% of teachers who teach mathematics classes at the lower- secondary level have neither a major nor a minor in mathematics or related disciplines, as opposed to $10 \%$ of teachers who teach at the upper-secondary level. Finally, in private schools, $28 \%$ of teachers who teach mathematics classes at the upper-secondary level have neither a major nor a minor in mathematics, or related disciplines as opposed to $13 \%$ of teachers who teach at the upper-secondary level.

Concerning teachers who teach without an undergraduate or graduate major in the field, there are increasing percentages of teachers who teach without an undergraduate or graduate major in the field. This means that many teachers in Thailand are assigned to teach out of their major. For example, $26 \%$ of teachers teach social studies classes and mathematics classes without an undergraduate or graduate major in the field..

One source of variation in outof-field teaching is school type. Public schools have higher levels of out-of-field teaching than do private schools in the subjects of social studies, Thai language, sciences, and English language, but there are not differences in mathematics.

Out-of-field teaching also varies by grade level, with both public and private schools having great differences in out-of-field teaching between lower-secondary and uppersecondary levels. The percentages of teachers who teach without an undergraduate or graduate major in the field at lower-secondary level is higher than those at the uppersecondary level. For example, in public schools, the data show $34 \%$ of teachers who teach mathematics at the lower-secondary level without an undergraduate or graduate major in mathematics, or related disciplines, compared with $8 \%$ in uppersecondary. Finally, in private schools, $31 \%$ of teachers who teach mathematics classes at lowersecondary level as opposed to $15 \%$ of those who teach at upper- secondary level are without an undergraduate or graduate major in mathematics, or related disciplines.

\section{Implications and Conclusions}

The implementation of educational reform to promote quality involves all sectors of society. In moving towards the success of the reform along the lines stipulated by the 1999 National Education Act, the most effective strategies involve building partnerships and networks and encouraging people's participation. Through a lifelong process, the new culture of learning will lead to the development of learners in all aspects-physical, mental or emotional, social and intellectual, thus paving the way for the transformation of Thai society into a learning one. Qualified teachers are meaningful and necessary for the educational reform to be successful. There are a lot of reasons why underqualified teachers pose the most important problem needing a solution.

One possible source of the problem is the standards themselves. The depth, breadth and rigor of college or university teacher preparation programs and certification standards have long been the target of critics. In this case, remedies include reformation of state licensing requirements and institutional preparation programs.

Another source of the problem is 
the failure of teachers to meet the standards because of deficits in their preparation or education. Falling into this category are those without college degrees and those without any teaching license.

Even another source of underqualified teaching arises in how teachers are utilized once on the job-the problem of out-of-field teaching. Remedies to these mismatches should include reforming the way teachers are managed and assigned in schools.

Most researchers and commentators assume that the source of the problem of underqualified teachers lies primarily in the first two inadequacies, either in the standards or in the credentials of the teaching candidates. Consistent with this perspective, the dominant policy responses have been in attempting to upgrade the quality of teachers through more rigorous training and testing and licensing requirements. In contrast, the data indicate that of equal or greater importance is out-offield teaching — a common practice whereby qualified teachers are assigned by school administrators to teach classes in subjects that do not match their fields of training or certification. The data show that this is widespread in Thailand, especially in those schools serving disadvantaged communities. 


\section{References}

Ministry of Education. (2006).

Toward a learning society in Thailand:

The education system in Thailand.

Retrieved February 20, 2007, from

http://www.bic.moe.go.th/fileadmin/BI

C_Document/book/MOEleaflet/Thai-

ed-system.pdf

Office of the Basic Education Commission. (2004). Statistical data of basic education in Thailand 2004.

Bangkok: Donmuang Printing.

Office of the National Education Commission. (1999). National Education Act of B.E. 2542 (1999). Bangkok: Seven Printing Group Co., Ltd.

Office of the Education Council. (2004). Education in Thailand 2004. Bangkok: Office of the Education Council.

Office of the Education Council. (2006). Education in Thailand 2005/2006. Bangkok: Office of the Education Council.

Professional Standards Bureau Secretariat Office of the Teacher's Council of Thailand. (2005). Educational professional standards. Bangkok: The Teacher's Council of Thailand.

Secretariat Office of the Teacher's Council of Thailand. (2006). Laws on teaching Profession (2). Bangkok: The Teacher's Council of Thailand.

Siribanpitak, P. (2005). Challenges of and opportunities for secondary school teachers in Thailand. Bangkok: Chulalongkorn University.
The Teachers' Council of Thailand. (2003). Teacher and Educational Personnel Act B.E. 2546 (2003). Retrieved February 20, 2007, from http://www.ksp.or.th/mainpage_en/inde x.php 
94 


\title{
CHAPTER 8
}

\section{The Preparation and Qualifications of the Teaching Force in the United States}

\author{
Richard M. Ingersoll \\ University of Pennsylvania
}

\section{Introduction}

Few educational issues have received more attention in recent times in the United States than the problem of ensuring that the nation's elementary and secondary classrooms are all staffed with quality teachers. This concern with the caliber of teachers is neither unique nor surprising. Elementary and secondary schooling is mandatory in the United States and children are legally placed in the care of teachers for a significant portion of their lives. The quality of teachers and teaching are undoubtedly among the most important factors shaping the learning and growth of students. Moreover, the largest single component of the cost of education is teacher compensation. Especially since the publication over two decades ago of the seminal report $\mathrm{A}$ Nation at Risk (National Commission on Excellence in Education, 1983), a seemingly endless stream of studies, commissions and national reports has targeted teacher quality as one of the central problems facing schools in the United States. Such critics have blamed teacher performance not only for the decline in student academic achievement but for numerous societal ills - the erosion of American economic competitiveness and productivity; teenage pregnancy; juvenile delinquency and crime; the coarsening of everyday discourse and culture; a decline in morals; gender and racial discrimination, and so on.

In response, the federal government in 2002 enacted the most significant educational reform in the United States in recent yearsthe No Child Left Behind Act. In addition to new standards for student achievement, this legislation set a new and unprecedented goal - to ensure that the nation's public elementary and secondary students all are taught by highly qualified teachers. The No Child Left Behind Act also introduced a new and unprecedented means to achieve this goal-accountability - to assess how well public schools are doing in regard to the new standards and to sanction schools that do not meet them. Behind this legislation, and contemporary educational thought in the United States, lie two popular views as to the source of the staffing and teacher-quality problems plaguing schools. The first focuses on inadequacies in the qualifications of teachers; the second focuses on inadequacies in the quantity, or supply, of teachers.
The first view holds that a major source of low-quality teachers and teaching is inadequate and insufficient pre-employment preparation. Critics and reformers subscribing to this view have advocated for more rigor in the coursework requirements and entry standards for the teaching occupation. From this viewpoint, the way to upgrade the quality of teaching is to alter the preparation required of new teachers.

There is, however, much debate over how to best define a "qualified teacher" and what adequate teaching qualifications entail. Although there is almost universal agreement in the United States that teachers do matter, that student learning is affected by the quality of teaching, and that teachers ought to be qualified, there is a great deal of controversy and much skepticism concerning which kinds of courses, preparation and qualifications teachers ought to have to be considered adequately qualified.

One of the key areas of difference in this debate concerns the relative value of teachers' educational preparation and of their professional preparation. The former refers to the level of post-secondary education in a field — the degrees - required of teaching candidates. The latter refers to the occupation-specific training 
required of those entering teaching. On one end of this continuum are those who argue that academic content or subject knowledgeknowing what to teach-is of primary importance for one to be a qualified teacher. Advocates of this view often hold that professional degrees in education are overloaded with required courses in pedagogy to the neglect of coursework in academic subjects. Such critics also tend to question the value of government-based entry regulations such as teaching certificates. At its extreme, this viewpoint assumes that training in teaching methods is unnecessary and that having an academic degree in a subject is sufficient to be a qualified teacher in that subject.

On the other end of this continuum are those who argue that professional, pedagogical and methodological knowledgeknowing how to teach-is of primary importance to be a qualified teacher. In this view, in-depth knowledge of a subject is less important than in-depth skill at teaching. At its extreme, this viewpoint holds that "a good teacher can teach anything."

For most occupations and professions in the United States, it typically is taken as a given that particular credentials are necessary to practice particular kinds of work. However, for most occupations and professions there has been little, if any, empirical research done assessing the value added by practitioners having a particular credential, license or certification (Kane, 1994;

American Educational Research Association/American Psychological Association/National Council on Measurement in Education, 1999). In this respect, teaching is unusual; there is an extensive body of empirical research, going back decades, devoted to assessing the effects of various teacher qualifications on teacher and student performance. For measures of qualifications, researchers typically examine teachers' test scores or teachers' credentials, such as degrees, reflecting a variety of types of education and training. A substantial number of studies have found teacher education, preparation or training, of one sort or another, to be significantly related to increases in student achievement (e.g., Greenwald, et al., 1996). For example, two recent analyses of national data found that eighth-grade students of mathematics whose teachers had a regular teaching certificate in mathematics or had a college degree in mathematics or in mathematics education scored significantly higher on eighth-grade math tests (Raudenbush, et al., 1999; Greenberg, et al., 2004).

These are telling findings given the widespread criticism from both insiders and outsiders that teacher education is of low quality in the United States. But, the results from this empirical literature also are at times contradictory, and there are also some studies showing no positive effects of various measures of teacher qualifications. Moreover, there also are large gaps in this research (for a recent review, see Allen, 2003). Given the inherent difficulties in accurately isolating and capturing the effects of teacher's qualifications on their students' achievement and the weaknesses of much of the extant data and empirical research, this is not surprising. However, these data and research limitations and inconsistencies also fuel the ongoing debate over how best to define a qualified teacher.

A second popular explanation for the staffing and teacher-quality problems plaguing schools in the
United States is teacher shortages. In this view, the main problem is that the supply of new teachers is insufficient to keep up with the demand. The root of this gap, it is widely believed, is a dramatic increase in the demand for new teachers primarily resulting from two converging demographic trendsincreasing student enrollments and increasing teacher retirements due to a "graying" teaching force. Shortfalls of teachers, this argument continues, have meant that many school systems have not been able to find qualified candidates to fill their openings, inevitably resulting in the hiring of underqualified teachers and, ultimately, lowering school performance.

The prevailing policy prescription and response has been to attempt to increase the supply of teachers through a wide range of recruitment initiatives. There are programs that aim to entice mid-career professionals to become teachers. Some schools have instituted initiatives to recruit teaching candidates from overseas and from other nations. Financial incentives, such as signing bonuses, housing assistance, and college tuition reimbursement, have all been used to aid teacher recruitment (Hirsch, Koppich, \& Knapp, 2001).

But there is growing criticism over the accuracy of this conventional view of teacher shortages and the effectiveness of the new teacher recruitment reforms.

Recent data analyses have documented that the main source of school staffing problems is not one of shortages, in the sense of too few new teachers being produced (Ingersoll, 2001; 2003a). Rather the data show the source of the problem lies in too many teachers departing their teaching jobs long before retirement. Most of the demand for new teachers is driven not by student 
enrollment or teacher retirement increases but by pre-retirement teacher turnover. The data portray a "revolving door" occupation in which there are relatively large flows of teachers in, through and out of schools each year. Teaching also is an occupation that loses many of its newly trained members very early in their careers. The data indicate that as many as half of those trained to be teachers never enter teaching, and another $40-50 \%$ of those who do enter leave teaching altogether in the first five years. Moreover, the data indicate that the overall volume of turnover accounted for by retirement is relatively minor when compared with that resulting from other causes, such as teacher job dissatisfaction and teachers seeking better jobs or other careers.

Such findings raise serious doubts about the ultimate success of current teacher recruitment initiatives in the United States. In short, the data indicate that recruiting more teachers will not solve school staffing problems if large numbers of such teachers then leave in a few years. As a result, an increasing number of leading education-reform groups, such as the National Commission on Teaching and America's Future (2003), have argued that the solution to staffing and teacher-quality problems plaguing schools in the United States lies in improved teacher retention.

\section{Teacher Preparation Requirements and Standards}

These competing views as to the sources of, and solutions to, teacherquality problems in the United States have been shaped by the way the educational system in the United States is organized. Historically, the control and governance of elementary and secondary schooling developed in an unusual manner in the United States. In contrast to most nations, publicly funded mass schooling in the United States was originally begun on a highly localized and decentralized basis (Tyack, 1974). The framers of the U.S. Constitution did not include education or schooling among the functions of the national/federal government and, hence, the provision of schooling began as the responsibility of the 50 individual states. The states, in turn, delegated substantial control to local, community-based educational authorities. From the early development of public schooling in the 19th century, the accepted operating principle was that the schooling of children should largely be the responsibility of the communities and towns in which the students and their families resided. This doctrine of local control of schooling continues to be a dominant value in the United States. The resulting legacy is a current system of about 14,500 individual public school districts, governed by school boards who hold legal responsibility for 45 million students in 84,000 publicly funded elementary and secondary schools employing almost 3 million teachers. Another 5 million students are enrolled in about 27,000 private schools that are not operated, or primarily funded, by local or other government. These private schools employ about 450,000 teachers.

The history of public schooling in the United States also has been a story of the chronic erosion of this foundation of local and decentralized control. Particularly since the mid 20th century, there has been a dramatic increase in the control and influence over districts and schools exerted by higher levels of government and by a wide array of nongovernmental groups and organizations. The 50 states themselves have increased their scrutiny and regulation over a wide range of aspects of schooling. Especially in the past half century, the role of the national government also also increased. As a result of this growth in centralized and external influence, schools and local school districts in the United States clearly are not the autonomous bodies they once were. But, despite these changes, the U.S. educational system remains to a large extent far more decentralized than in many other nations (OECD, 1995, 1998). That is, far more educational decisions are made by districts and states than by the national government. In particular, it is the responsibility of the 50 states to regulate entry into the teaching occupation in their respective school systems. Entry, training, testing and licensing requirements for teachers are largely set and controlled by the 50 individual states. The result is an occupation with a diversity of entry routes, requirements and standards.

In the United States, teaching as an occupation has an unusually ambivalent character. Compared to other occupations and to professions, teaching is relatively complex work, but it also is an occupation with relatively low pre-employment entry requirements.

Among those who study work, organizations and occupations in general, teaching traditionally has been classified as a relatively complex form of work, characterized by uncertainty, intangibility and ambiguity and requiring a high a degree of initiative, thought, judgment and skill to do well (e.g., Bidwell, 1965; Lortie, 1975; see also Cohen, Raudenbush, \& Ball, 2003). For example, in a classic comparative 
study of a number of occupations, Kohn and Schooler (p. 68, 1983) concluded that secondary teaching involved greater substantive complexity than the work of accountants, salespersons, machinists, managers and officials in service industries and in the retail trade.

Despite its complexity, from a cross-occupational perspective, teaching has long been characterized as an easy-entry occupation. Compared with other work and occupations and, in particular compared to high-status traditional professionals, such as physicians, professors, attorneys, engineers, architects, accountants, and dentists, teaching has a relatively low entry "bar," and a relatively wide entry "gate" (Etzioni, 1969; Lortie, 1975; Ingersoll, 2001). Historically, teaching had a number of mechanisms that facilitated ease of entry into the occupation. First, teacher training was made relatively accessible. Beginning in the early part of the 20th century, the states created large numbers of low-cost, dispersed, and noncompetitive teacher-training institutions. Currently there are 1,206 teacher training schools or programs in colleges and universities in the United States. Teaching also has a relatively wide "decision range"-individuals can decide to become teachers at any number of points in their life span. Finally, most who desire to enter the teaching occupation are free to do so-individuals choose the occupation, not vice versa. In contrast, the opposite prevails in many occupations and in most traditional professions. Especially in the latter, entry standards are very selective and occupational "gatekeepers" have a large say in choosing new members and not all who desire to enter are allowed to do so.
As mentioned earlier, the federal government in 2002 enacted a new and unprecedented mandate in the No Child Left Behind Act to ensure that all public elementary and secondary students are taught by highly qualified teachers. In general, the No Child Left Behind Act defines a "highly qualified" teacher as someone who has completed a fouryear baccalaureate degree, who holds a state-issued teaching certificate or license, and who has established competency in the academic subjects he or she teaches. By design, however, it is the responsibility of each of the 50 states to interpret and implement these general standards.

Teaching certificates usually are issued for a particular field, such as mathematics or English. Obtaining teaching certification usually requires completion of undergraduate-level coursework in the subject matter of a particular field, and also in professional knowledge, such as pedagogy and teaching methods. Certification also usually entails passage of written examinations in both pedagogy and content knowledge. Finally, certification also usually requires completion of a program of practice or student teaching

But, the depth, breadth and rigor of teacher certification requirements vary dramatically among the states. In addition, in some states certification expires after a set number of years and renewal requires the completion of additional collegelevel coursework; in other states, certification is permanent. Moreover, not all of those who enter the teaching occupation are required to hold a certificate. For instance, in many states teachers in private schools are not required to be certified. The same lack of uniformity applies to the means by which candidates are allowed to establish "competency" in a particular subject or field. The states vary as to whether they require tests, as to the content of the tests, and where they set the minimum cutoff scores required of candidates to pass the test.

There also are a growing number of different routes for entering teaching. Traditionally, most of those entering teaching did so after the completion of a four-year bachelor's degree in education, which included certification. A smaller number of college graduates, who completed a bachelor's degree in a field other than education, entered teaching by enrolling in what is called a "fifthyear program" - a post-baccalaureate one-year teacher preparation program leading to a teaching certificate. But, there are increasing numbers of alternative entry routes whereby college graduates can postpone formal education preparation, obtain a less-than-full (e.g., temporary or alternative) teaching certificate, and begin teaching immediately.

The next sections present data on the proportions of the U.S. elementary and secondary teaching force that has completed various above-described education, training and preparation requirements.

\section{Data and Measures}

The data presented in this chapter come from the nationally representative Schools and Staffing Survey (SASS) conducted by the National Center for Education Statistics, the statistical arm of the U.S. Department of Education. This is the largest and most comprehensive source of information and data on teachers in the United States. The SASS data are collected from random samples stratified by state, sector, and school level. To 
date, five independent cycles of SASS have been completed and released: 1987-1988, 1990-1991, 1993-1994, 1999-2000 and 2003-2004. Each cycle of SASS includes several sets of separate, but linked, questionnaires for school administrators and for a random sample of teachers within each school. The response rate has been relatively high—about $85 \%$ for teachers and 95\% for administrators.

SASS is a large survey; in each cycle the sample sizes are about 5,000 school districts, 11,000 schools and 52,000 teachers. The teacher sample includes full-time, part-time and long-term substitute teachers from pre-kindergarten to the 12 th -grade level. The sample does not include short-term substitutes, teacher aides, practice or student teachers. SASS also is a comprehensive survey; it provides accurate data for all 50 states (and Washington, DC) and all types of schools. Relevant to this analysis, SASS collects extensive information on the education, training and certification and also the daily course schedules from its very large nationally representative sample of teachers. SASS does not collect data on teachers' exam or test scores. The data presented in the tables below are from the two most recent cycles of SASS - the 1999-2000 and the 2003-2004.

The data in the tables provide a national portrait of teachers' qualifications in the United States just prior to the enactment of the federal No Child Left Behind Act. There are a variety of reasons why elementary and secondary classrooms are sometimes not staffed by qualified teachers. Some causes can be traced to how candidates are prepared and licensed prior to teaching and some to how teachers are utilized once on the job. This chapter presents data for several different measures. First, it presents descriptive statistics on percentages of teachers according to their highest college degree and according to their type of teaching certificate and the extent to which these levels vary among different kinds of schools, according to their urbanicity, poverty, and grade level.

A second, and far less understood, source of underqualified teaching is the problem of out-offield teaching-teachers assigned to teach subjects that do not match their fields of preparation. This is a crucial factor because highly qualified teachers may actually become highly unqualified if they are assigned to teach subjects for which they have little background. Teachers trained, for example, in social studies may be unlikely to have a solid understanding of math or how to teach it. Hence, this chapter also presents data on levels of out-of-field teaching, and the extent to which these levels vary among different kinds of schools.

Previous studies have used a number of different measures of outof-field teaching, representing a range of standards (Ingersoll, 1999; 2003b). Some measures focus on whether teachers have a teaching certificate in the fields they teach; others focus on whether teachers have an undergraduate or graduate degree. Measures of out-of-field teaching also vary according to whether they choose to focus on the numbers of teachers doing it, or the numbers of students exposed to it, according to which fields and subjects are examined and also according to which grade levels are investigated.

This chapter presents three different measures of out-of-field teaching, drawn from this previous work: 1) percent teachers without an undergraduate or graduate major or minor in the field; 2) percent teachers without an undergraduate or graduate major in the field; and 3) percent teachers without a full teaching certificate or license in the field.

As defined here, the first two measures count as in-field both academic and education majors and minors (e.g., a mathematics teacher with a minor or major in either mathematics or in mathematics education). For all three measures I focus only on the four core academic fields: Mathematics; Science, Social Science/Social Studies and English. Chart 1 shows which secondary-level courses are included in each of the four fields, and which major/minor and certification fields count as infield for each. Science and social science are both defined broadly here. In other words, anyone who teaches any science course is defined as qualified or in-field if he or she holds a credential, such as a major, in science education or in any of the sciences, including chemistry, physics, geology, space science, and biology. Likewise, anyone teaching any courses in social studies is defined as qualified if he or she holds a credential in any of the social sciences or in social studies education. This is different from a narrow discipline-based definition of fields, such as used in the Hong Kong chapter. In the latter case, someone with a major in chemistry is not considered in-field or qualified in physics or biology, and vice versa.

Each measure focuses solely on teachers at the secondary grade level (grades 7-12). Each measure only includes departmentalized teachersthose who teach subject-matter courses to several classes of different students for all or most of the day. Excluded are those teaching selfcontained classes, in other words, those teaching multiple subjects to 


\begin{tabular}{|c|c|c|c|}
\hline \multicolumn{4}{|c|}{$\begin{array}{l}\text { Chart } 1 \\
\text { Matching Teaching Fields With Preparation Fields }\end{array}$} \\
\hline $\begin{array}{l}\text { I. } \\
\text { Fields }\end{array}$ & $\begin{array}{l}\text { II. } \\
\text { Teachers' Course Assignment Fields }\end{array}$ & $\begin{array}{l}\text { III. } \\
\text { Teachers' Major or Minor Fields }\end{array}$ & $\begin{array}{l}\text { IV. } \\
\text { Teachers' Certification Fields }\end{array}$ \\
\hline English & $\begin{array}{l}\text { literature } \\
\text { composition/journalism/creative writing } \\
\text { reading } \\
\text { other English/language arts courses }\end{array}$ & $\begin{array}{l}\text { communications or journalism } \\
\text { English } \\
\text { English education/language arts education } \\
\text { literature } \\
\text { reading education }\end{array}$ & $\begin{array}{l}\text { English or language arts } \\
\text { Journalism } \\
\text { Reading }\end{array}$ \\
\hline Mathematics & $\begin{array}{l}\text { general mathematics } \\
\text { business math } \\
\text { algebra, elementary } \\
\text { algebra, intermediate } \\
\text { algebra, advanced } \\
\text { geometry, plane/solid } \\
\text { trigonometry } \\
\text { analytical geometry } \\
\text { probability/statistics } \\
\text { calculus } \\
\text { other mathematics }\end{array}$ & $\begin{array}{l}\text { engineering } \\
\text { mathematics } \\
\text { mathematics education } \\
\text { physics } \\
\text { statistics }\end{array}$ & Mathematics \\
\hline Social Studies & $\begin{array}{l}\text { social studies } \\
\text { history } \\
\text { world civilization } \\
\text { political science/government } \\
\text { geography } \\
\text { economics } \\
\text { civics } \\
\text { sociology/social organization } \\
\text { other social science } \\
\text { psychology }\end{array}$ & $\begin{array}{l}\text { psychology } \\
\text { public administration } \\
\text { social studies/social sciences education } \\
\text { economics } \\
\text { history } \\
\text { political science } \\
\text { sociology } \\
\text { other social sciences } \\
\text { other area or ethnic studies } \\
\text { American Indian studies }\end{array}$ & $\begin{array}{l}\text { social studies or social sciences } \\
\text { history }\end{array}$ \\
\hline Science & $\begin{array}{l}\text { general science } \\
\text { biology/life science } \\
\text { chemistry } \\
\text { physics } \\
\text { geology/earth } \\
\text { science/space science } \\
\text { other physical science } \\
\text { other natural science }\end{array}$ & $\begin{array}{l}\text { science education } \\
\text { biology/life science } \\
\text { chemistry } \\
\text { earth science/geology } \\
\text { physics } \\
\text { other natural sciences } \\
\text { emgineering }\end{array}$ & $\begin{array}{l}\text { general science } \\
\text { biology/life science } \\
\text { chemistry } \\
\text { earth science/geology } \\
\text { physics } \\
\text { other natural sciences } \\
\text { physical science }\end{array}$ \\
\hline
\end{tabular}

the same students for all or most of the day, as is the norm in elementary schools.

\section{The Qualifications of the Teaching Force}

The data indicate that most teachers in the United States have completed an undergraduate college education and most also hold regular or full teaching certificates (see Table 1). Ninety-nine percent of elementary and secondary school teachers in public schools hold at least a bachelors' degree and almost half hold a master's degree or higher. Moreover, about $91 \%$ of public school teachers hold a regular or full teaching certificate in one field or another. Another 7\% hold a lessthan-full certificate (e.g., temporary, emergency or provisional). Less than $2 \%$ of public school teachers hold no teaching certificate of any type.
These latter data conflict with conventional wisdom in the United States. In recent years, much attention has been focused on the plight of school districts-especially those serving low-income, urban communities- that have been forced, because of shortages, to hire significant numbers of uncertified teachers to fill vacancies. The data suggest, however, that the numbers of teachers without a full certificate actually represent only a small 


\begin{tabular}{|c|c|c|c|c|c|c|c|}
\hline \multicolumn{8}{|c|}{$\begin{array}{l}\text { Table } 1 \\
\text { PERCENTAGE of Elementary and Secondary School Teachers in the United States, by Highest Degree Earned, and by Highest } \\
\text { Type of Teaching Certification or License, by Type of School, 2003-2004. }{ }^{1}\end{array}$} \\
\hline & \multicolumn{3}{|c|}{ Educational Qualifications } & \multicolumn{3}{|c|}{ Professional Qualifications } & \multirow{2}{*}{$\begin{array}{l}\text { Both Bachelor's } \\
\text { Degree and Full } \\
\text { Certification }\end{array}$} \\
\hline & $\begin{array}{l}\text { Less than } \\
\text { Bachelor's } \\
\text { Degree }\end{array}$ & $\begin{array}{l}\text { Bachelor's } \\
\text { Degree }\end{array}$ & $\begin{array}{l}\text { Master's } \\
\text { Degree or } \\
\text { Higher }\end{array}$ & $\begin{array}{c}\text { No } \\
\text { Cerifiication }\end{array}$ & $\begin{array}{l}\text { Less-than } \\
\text { Full } \\
\text { Certification }\end{array}$ & $\begin{array}{c}\text { Full } \\
\text { Certification }\end{array}$ & \\
\hline Total & 2. 1 & 52.9 & 45.0 & 6.5 & 6.8 & 86.6 & 85.8 \\
\hline Elementary & 1.3 & 54.4 & 44.4 & 4. 4 & 6.4 & 89.3 & 88.8 \\
\hline Secondary & 2.5 & 48.7 & 48.8 & 5.0 & 8.1 & 86.9 & 85.4 \\
\hline Public Schools & 1. 1 & 52.3 & 46.6 & 1.5 & 7.2 & 91.3 & 90.6 \\
\hline \multicolumn{8}{|l|}{ Poverty Level } \\
\hline Low & 1.0 & 44.4 & 54.6 & 1.0 & 6.3 & 92.7 & 92.2 \\
\hline High & 1.7 & 57.6 & 40.7 & 2. 0 & 10. 1 & 88. 0 & 87.3 \\
\hline \multicolumn{8}{|c|}{ Community Type } \\
\hline Rural & 1.4 & 58.0 & 40.6 & 1.0 & 5.4 & 93.5 & 92.6 \\
\hline Suburban & 0.9 & 50.2 & 48. 9 & 1.4 & 6.6 & 92.0 & 91.4 \\
\hline Urban & 1.3 & 52.3 & 46.4 & 2. 0 & 9.5 & 88.5 & 87.7 \\
\hline \multicolumn{8}{|l|}{ Grade Level } \\
\hline Elementary & 0.4 & 58.0 & 40.6 & 1.3 & 6.5 & 92.2 & 91.9 \\
\hline Secondary & 2.6 & 48.7 & 48.7 & 1.7 & 8.4 & 89.9 & 88.3 \\
\hline Private Schools & 9.4 & 57.1 & 33.4 & 41.6 & 4. 0 & 54.3 & 52.9 \\
\hline \multicolumn{8}{|c|}{$\begin{array}{l}\text { a. Less-than-Regular Certification - includes all those with emergency, temporary, alternative or provisional certification. } \\
\text { b. Regular Certification - includes all those with probationary, regular, standard, full or advanced certification. } \\
\text { (Probationary - refers to initial license issued after satisfying all requirements except completion of an initial probationary period of teaching) } \\
\text { c. Low poverty refers to schools where } 10 \% \text { or less of the students enrolled are from families below the official governmental poverty line. High poverty refers to schools where } \\
\text { over } 80 \% \text { are below the poverty line. }\end{array}$} \\
\hline
\end{tabular}

proportion of the teachers in public schools. Of the 3,250,000 teachers in public schools in the 2003-04 school year, about 235,000 had only a lessthan-full certificate, and another 48,000 teachers had no certificate at all.

The data in Table 1 also reveal some distinct cross-school differences in the qualifications of teachers. Students in schools with a high poverty enrollment sometimes have less access to qualified teachers. For example, teachers in high-poverty schools are less likely to have graduate-level degrees and slightly less likely to hold a full teaching certificate than teachers in lowpoverty schools. Teachers in private schools are far less likely to hold a certificate because, as mentioned, many states do not require teachers in private schools to be certified.

While providing a useful portrait of the basic education and training of the teaching force in the United States, it also is important to acknowledge that these measures of degrees and certificates tell us little of the quality or these qualifications. We do not have analogous national data on teachers' exam or test scores. Hence, there may be inadequacies or inequities not revealed here.

\section{Out-of-Field Teaching}

The most glaring and prominent source of inadequate access to qualified teachers in the United States is not a lack of basic education or training of teachers, but rather a lack of fit between teachers' preparation and teachers' class assignments. This is a result of the practice of out-of-field teachingwhere teachers educated and trained in one field are assigned by school administrators to teach classes in another field.

As mentioned earlier, the data in Tables 2, 3 and 4 show three different measures of out-of-field teaching. Table 2 shows percent 
teachers without an undergraduate or graduate major or minor in the field. Table 3 shows percent teachers without an undergraduate or graduate major in the field. Table 4 shows percent teachers without a full teaching certificate or license in the field taught.

Each table reveals that there are many teachers assigned to teach classes in fields that do not match their educational background. For example, as shown in Table 2 about one third of all those who teach secondary-school mathematics classes have neither a major nor a minor in mathematics, mathematics education, or in related disciplines like engineering, statistics or physics. About $28 \%$ of all those teaching secondary-school English classes have neither a major nor a minor in English or related subjects such as literature, communications, speech, journalism, English education, or reading education. In science, which is defined as a broad field, slightly lower levels-about $22 \%$ of all those teaching secondary-school classesdo not have at least a college minor in any one of the sciences or in science education. Finally, about $22 \%$ of those teaching social studies are without at least a minor in any of the social sciences, in public affairs, in social studies education, or in history. The data also show that levels of out-of-field teaching are higher in the seventh and eighth grades than in ninth to 12 th grades.

There are large cross-school differences in out-of-field teaching. In most fields, teachers in highpoverty schools are more likely to be assigned to teach out of their field than are those in more affluent schools. For example, 39\% of those teaching math classes in high-poverty schools, as opposed to $26 \%$ in lowpoverty schools, are out of field. To be sure, more affluent schools are not

Table 2

PERCENTAGE of Secondary Grade Level Teachers in the United States in the Core Academic Fields Without an Undergraduate or Graduate Major or a Minor in the Field, by Type of School, 1999-2000

\begin{tabular}{|lcccc|}
\hline & $\begin{array}{c}\text { Native } \\
\text { Language } \\
\text { (English) }\end{array}$ & Math & Science & $\begin{array}{c}\text { Social } \\
\text { Science }\end{array}$ \\
\hline Total & 28 & 32 & 22 & 22 \\
Public Schools & 27 & 30 & 21 & 22 \\
Poverty Enrollment & & & & \\
$\quad$ Low & 21 & 26 & 19 & 16 \\
High & 41.7 & 51.4 & 32 & 24 \\
Community Type & 28 & 32 & 24 & 25 \\
$\quad$ Rural & 26 & 29 & 20 & 20 \\
$\quad$ Suburban & 29 & 32 & 22 & 20 \\
$\quad$ Urban & & & & \\
Grade Level & 42 & 47 & 32 & 28 \\
$\quad$ Lower Secondary (7-8th grades) & 24 & 28 & 20 & 21 \\
$\quad$ Upper Secondary (9-12th grades) & & & 26 & 21 \\
Private Schools & 33 & 40 & 26 & \\
\hline
\end{tabular}

${ }^{2}$ Definitions:

a. Secondary school grade levels refer to those teaching grades 7-12th. It excludes those teaching subject-matter courses at the 7-8th grade levels who are employed in middle and elementary schools.

b. Low poverty refers to schools where $10 \%$ or less of the students enrolled are from families below the official federal government poverty line. High poverty refers to schools where over $80 \%$ are below the poverty line.

c. Private Schools refer to those that are neither primarily funded nor administered by local, state or federal government.

free of out-of-field teaching. Many teachers in these kinds of schools also teach out of their fields. But misassignment is clearly a major factor behind lack of access to qualified teachers in high-poverty schools. The poverty gaps for out-offield teaching (in Table 2) are distinctly wider than the poverty gaps for teacher qualifications (in Table 1). In other words, although teachers in high-poverty schools are slightly more likely to have fewer qualifications, they are far more likely to be misassigned than are those in low-poverty schools.

Another important source of variation for out-of-field teaching is school sector. Private schools have higher levels of out-of-field teaching in three of the four core academic fields than do public schools. In other analyses (not shown here), the data also show large differences among private schools, according to their size. Private schools appear to have both the highest and lowest levels of out-of-field teaching. On the one hand, large private schools have unusually low overall levels of out-offield teaching. On the other hand, small private schools have among the highest overall levels of out-of-field teaching. This suggests there is a large degree of diversity, at least in regard to teacher qualifications, in the private sector-something often overlooked in the ongoing debate over public versus private schooling in the United States.

Finally, levels of out-of-field teaching depend upon how this 


\begin{tabular}{|c|c|c|c|c|}
\hline \multicolumn{5}{|c|}{$\begin{array}{l}\text { Table } 3 \\
\text { PERCENTAGE of Secondary Grade Level Teachers in the United States in the } \\
\text { Core Academic Fields Without an Undergraduate or Graduate Major in the Field, } \\
\text { by Type of School, } 1999-2000^{3}\end{array}$} \\
\hline & $\begin{array}{l}\text { Native } \\
\text { Language } \\
\text { (English) }\end{array}$ & Math & Science & $\begin{array}{c}\text { Social } \\
\text { Science }\end{array}$ \\
\hline Total & 35 & 38 & 29 & 30 \\
\hline Public Schools & 35 & 37 & 29 & 30 \\
\hline \multicolumn{5}{|l|}{ Poverty Enrollment } \\
\hline Low & 28 & 31 & 23 & 23 \\
\hline High & 43 & 44 & 37 & 36 \\
\hline \multicolumn{5}{|l|}{ Community Type } \\
\hline Rural & 38 & 39 & 35 & 37 \\
\hline Suburban & 33 & 36 & 25 & 27 \\
\hline Urban & 35 & 37 & 29 & 27 \\
\hline \multicolumn{5}{|l|}{ Grade Level } \\
\hline Lower Secondary (7-8th grades) & 51 & 57 & 43 & 40 \\
\hline Upper Secondary (9-12th grades) & 31 & 34 & 26 & 28 \\
\hline Private Schools & 36 & 45 & 31 & 30 \\
\hline \multicolumn{5}{|c|}{$\begin{array}{l}\text { Definitions: } \\
\text { a. Secondary school grade levels refer to those teaching grades } 7-12 \text { th. It excludes those teaching subject-matte } \\
\text { courses at the 7-8th grade levels who are employed in middle and elementary schools. } \\
\text { b. Low poverty refers to schools where } 10 \% \text { or less of the students enrolled are from families below the official } \\
\text { federal government poverty line. High poverty refers to schools where over } 80 \% \text { are below the poverty line. } \\
\text { c. Private Schools refer to those that are neither primarily funded nor administered by local, state or federal gov- } \\
\text { ernment. }\end{array}$} \\
\hline
\end{tabular}

phenomenon is defined and measured. For example, as shown in Table 3, when the definition of an in-field teacher is raised to include only those with a full major in the field, in contrast to a major or a minor as in Table 2, levels of out-offield teaching increase dramatically.

Background analyses of the data also show that those teaching out of field are typically veterans with an average of 14 years of teaching experience, and about $45 \%$ of outof-field teachers hold graduate degrees, but in disciplines other than the subjects in which they have been assigned to teach. Hence, out-of-field teachers typically are experienced and qualified individuals who have been assigned to teach in fields that do not match their training or education. misassignment, but the data reveal two important shortcomings with this explanation. First, it cannot explain high levels of out-of-field teaching in fields such as English and social studies, where there are surpluses of qualified teachers. Second, the data show that about half of all misassigned teachers work in schools that reported no difficulties finding qualified candidates for job openings that year (Ingersoll, 2003b).

The data point toward another explanation: the manner in which schools are organized and teachers are managed. School staffing decisions usually follow a top-down command model: these decisions are the prerogative of school administrators and teachers typically have little say over their assignments. School administrators face the difficult task of providing an increasingly broad array of programs with limited resources, time, budgets, and teaching staff. But, within those constraints, administrators have an unusual degree of discretion, and there is little centralized regulation of how teachers are utilized once they are hired. In this context, administrators report that, from a managerial perspective, they find that assigning teachers to teach out of their fields is often more convenient, less expensive, and less timeconsuming than the alternatives.

For example, rather than hire a new part-time science teacher for two sections of a newly state-mandated science curriculum, an administrator may find it simpler to assign two English or social-studies teachers to cover the science sections. When faced with a tough choice between hiring an unqualified candidate for a mathematics teacher position or doubling the class size of one of the fully qualified mathematics teachers, an administrator might opt for the 


\begin{tabular}{|c|c|c|c|c|}
\hline \multicolumn{5}{|l|}{$\begin{array}{l}\text { Table } 4 \\
\text { PERCENTAGE of Secondary Gr } \\
\text { Core Academic Fields Without a }\end{array}$} \\
\hline & $\begin{array}{l}\text { Native } \\
\text { Language } \\
\text { (English) }\end{array}$ & Math & Science & $\begin{array}{l}\text { Social } \\
\text { Science }\end{array}$ \\
\hline Total & 29 & 32 & 29 & 30 \\
\hline Public Schools & 24 & 27 & 23 & 25 \\
\hline \multicolumn{5}{|l|}{ Poverty Enrollment } \\
\hline Low & 18 & 27 & 23 & 23 \\
\hline High & 32 & 30 & 38 & 28 \\
\hline \multicolumn{5}{|l|}{ Community Type } \\
\hline Rural & 24 & 27 & 23 & 23 \\
\hline Suburban & 22 & 25 & 22 & 24 \\
\hline Urban & 28 & 32 & 26 & 28 \\
\hline \multicolumn{5}{|l|}{ Grade Level } \\
\hline Lower Secondary (7-8th grades) & 29 & 32 & 27 & 26 \\
\hline Upper Secondary (9-12th grades) & 23 & 27 & 22 & 25 \\
\hline Private Schools & 58 & 61 & 60 & 64 \\
\hline \multicolumn{5}{|c|}{$\begin{array}{l}\text { Definitions: } \\
\text { a. Secondary school grade levels refer to those teaching grades } 7-12 \text { th. It excludes those teaching subject-matter } \\
\text { courses at the } 7-8 \text { th grade levels who are employed in middle and elementary schools. } \\
\text { b. Low poverty refers to schools where } 10 \% \text { or less of the students enrolled are from families below the official } \\
\text { federal government poverty line. High poverty refers to schools where over } 80 \% \text { are below the poverty line. } \\
\text { c. Private Schools refer to those that are neither primarily funded nor administered by local, state or federal gov- } \\
\text { ernment. }\end{array}$} \\
\hline
\end{tabular}

former. If a full-time music teacher is under contract, but student enrollment is sufficient to fill only three music classes, the principal may find it both necessary and costeffective in a given semester to assign the music teacher to teach two classes in English, in addition to the three classes in music, in order to employ the teacher for a regular full-time complement of five classes per semester. If a school has three fulltime social-studies teachers, but needs to offer the equivalent of 3 ? full-time positions, and also has more than enough full-time English teachers, one solution would be to assign one of the English teachers to teach both English courses and some social-studies courses. field, but not have gotten a credential.

Moreover, out-of-field teaching is not the norm for most teachers and the data show that almost none are teaching out of their fields for their entire course load. Misassignments typically involve one or two classes out of a normal daily schedule of five classes. Most 7-12th grade subjectarea teachers have a main field or a primary department in which they teach, and the data show that most do have either a certificate or a degree in this main field. But many of these teachers also are assigned to teach some classes each day in other fields or departments. Mathematics teachers, for example, may not simply teach math; they also may be assigned to teach biology for part of the day. It is in these other assignments that teachers most often have little background.

\section{Implications}

If educational reform is to succeed in solving the problem of underqualified teachers, it must address the major sources of the problem. There are a variety of possible reasons why elementary and secondary classrooms may sometimes not be staffed by qualified teachers and these are sometimes confused and confounded.

One possible source is the standards themselves. The depth, breadth, and rigor of college or university teacher-preparation programs and state certification standards in the United States. have long been the target of critics. One criticism is that in some states prospective teachers have not been required to have completed sufficient coursework in the subject matter of their field. In this case, remedies must look to reform of state licensing 
requirements and institutional preparation programs.

Another source is the failure of some teachers to meet the standards because of deficits in their preparation or education. Falling into this category are those without a four-year college degree, those without any teaching certificate, and those who hold one of the many types of less-than-full teacher certificates issued by statesemergency, temporary, alternative, provisional, etc. The latter are issued to those who need to complete additional coursework or student practice teaching in order to obtain a full certificate, or to those who are participating in, but have not yet completed, an alternative training program. Typically, it is assumed that shortages are a major factor behind these inadequacies in teachers' qualifications. From this viewpoint, shortfalls in the numbers of available qualified teachers have forced many schools to hire teachers who are not qualified.

Even another source of underqualified teaching arises in how teachers are utilized once on the job-the problem of out-of-field teaching. Remedies to these mismatches must look to reform of the way teachers are managed and assigned in schools.

In the United States, most researchers and commentators assume the problem of underqualified teachers lies primarily in the first two sourcesinadequacies in either the standards or the qualifications of the available supply of teaching candidates.

Consistent with this perspective, the dominant policy responses, as discussed in the introduction of this chapter, have been to upgrade the qualifications of teachers through more rigorous education, training, testing and licensing requirements, and to provide incentives to recruit more candidates into teaching. In contrast, the data indicate that of equal or greater importance is the out-of-field teaching-a common practice whereby otherwise qualified teachers are assigned by school administrators to teach classes in subjects which do not match their fields of training or certification. The data show this is widespread in the United States, especially in those schools serving disadvantaged communities.

Understanding the reasons behind out-of-field teaching assignments is important because of the implications for solving the problem. In focusing on teachertraining requirements and teacher recruitment, most contemporary teacher-reform initiatives in the United States have overlooked the impact of the organizational and occupational contexts within which teachers work. The data, however, indicate that solutions to the problem of underqualified teachers also must look to how schools are managed and how teachers are utilized once they are on the job. In short, recruiting thousands of new candidates and providing them with rigorous preparation will not solve the problem if large numbers of teachers receive assignments for which they are not prepared. 


\section{References}

Allen, M. (2003). Eight questions on teacher preparation: What does the research say? Denver, CO: Education of the States. Retrieved February 20, 2007, from www.ecs.org/tpreport.

American Educational Research Association, American Psychological Association, National Council on Measurement in Education. (1999). Standards for educational and psychological testing. Washington, DC: Author.

Cohen, D., Raudenbush, S., \& Ball, D. (2003). Resources, instruction and research. Educational Evaluation and Policy Analysis, 25(2), 119-142.

Etzioni, A. (Ed.) (1969). The semi professions and their organizations: Teachers, nurses and social workers. New York: Free Press.

Greenberg, E., Rhodes, D., Ye, X., \& Stancavage, F. (2004). Prepared to teach: Teacher preparation and student achievement in 8th grade mathematics. Paper presented at the American Educational Research Association Annual Meeting, San Diego.

Greenwald, R., Hedges, L., \& Laine, R. (1996). The effect of school resources on student achievement. Review of Educational Research, 66, 361-396.

Hirsch, E., Koppich, J., \& Knapp, M. (2001). Revisiting what states are doing to improve the quality of teaching: An update on patterns and trends. Center for the Study of Teaching and Policy, University of Washington.
Ingersoll, R. (1999). The problem of underqualified teachers in American secondary schools. Educational Researcher, 28(2), 26-37.

Ingersoll, R. (2001a). The status of teaching as a profession. In J. Ballantine and J. Spade (Eds.), Schools and Society: a Sociological Approach to Education. Belmont, CA: Wadsworth Press.

Ingersoll, R. (2001b). Teacher turnover and teacher shortages: An organizational analysis. American Educational Research Journal, 38(3), 499-534.

Ingersoll, R. (2003a). Is there really a teacher shortage? Philadelphia:

Consortium for Policy Research in Education, University of Pennsylvania, and the Center for the Study of Teaching and Policy, University of Washington.

Ingersoll, R. (2003b). Out-of-field teaching and the limits of teacher policy. Philadelphia: Consortium for Policy Research in Education, University of Pennsylvania, and the Center for the Study of Teaching and Policy, University of Washington.

Kane, M. (1994). Validating interpretive arguments for licensure and certification examinations. Evaluation \& The Health Professions, 17(2), 133-159.

Lortie, D. (1975). School teacher. Chicago: University of Chicago Press.

National Commission on Excellence in Education. (1983). A nation at risk: The imperative for educational reform. Washington, DC: Government Printing Office.
National Commission on Teaching and America's Future. (1996). What matters most: Teaching for America's future. New York: NCTAF

National Commission on Teaching and America's Future. (1997). Doing what matters most: Investing in quality teaching. New York: NCTAF.

National Commission on Teaching and America's Future. (2003). No dream denied: A pledge to America's children. Washington, DC: NCTAF.

Organization for Economic Cooperation and Cultural Development (OECD). (1995). Decision-making in 14 OECD education systems. Paris: OECD.

Organization for Economic Cooperation and Cultural Development (OECD). (1998). Education at a glance: OECD indicators. Paris: OECD.

Raudenbush, S., Fotiu, R., \& Cheong, Y. (1999). Synthesizing results from the trial state assessment. Journal of Educational and Behavioral Statistics. 24(4), 413-438.

Tyack, D. (1974). The one best system. Cambridge, MA: Harvard University Press. 